
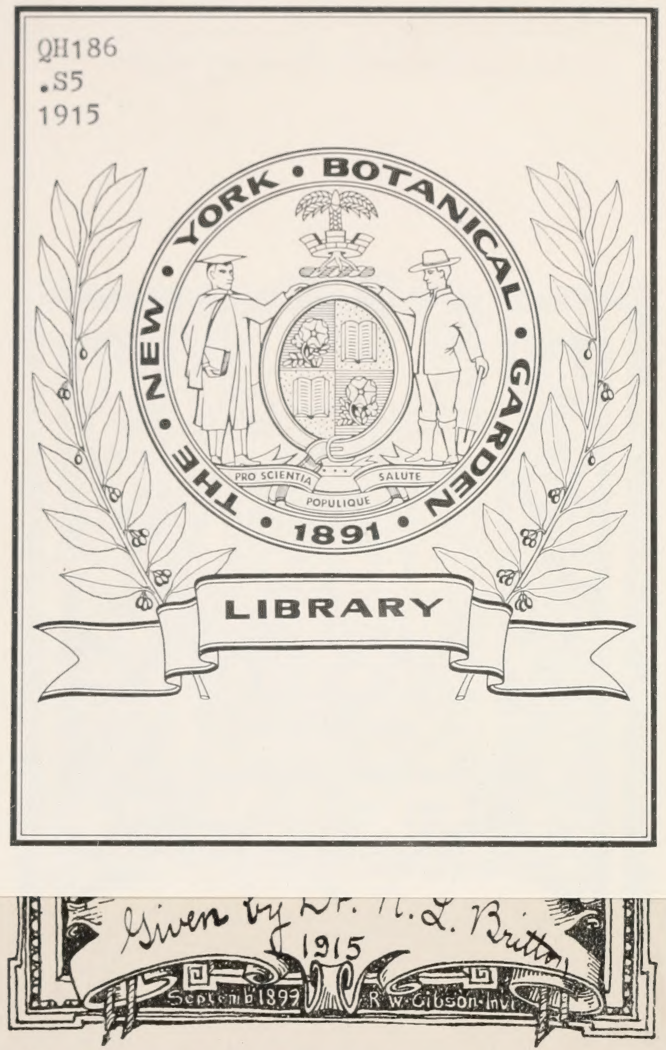






\section{INDISCH NATUURONDERZOEK}

M. J. SIRKS 



XA AFTAOTP DEHE PTRQMTOTTTE

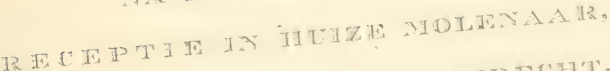

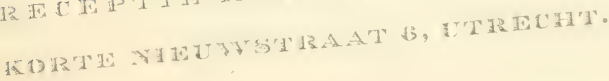



INDISCH NATUURONDERZOEK. 




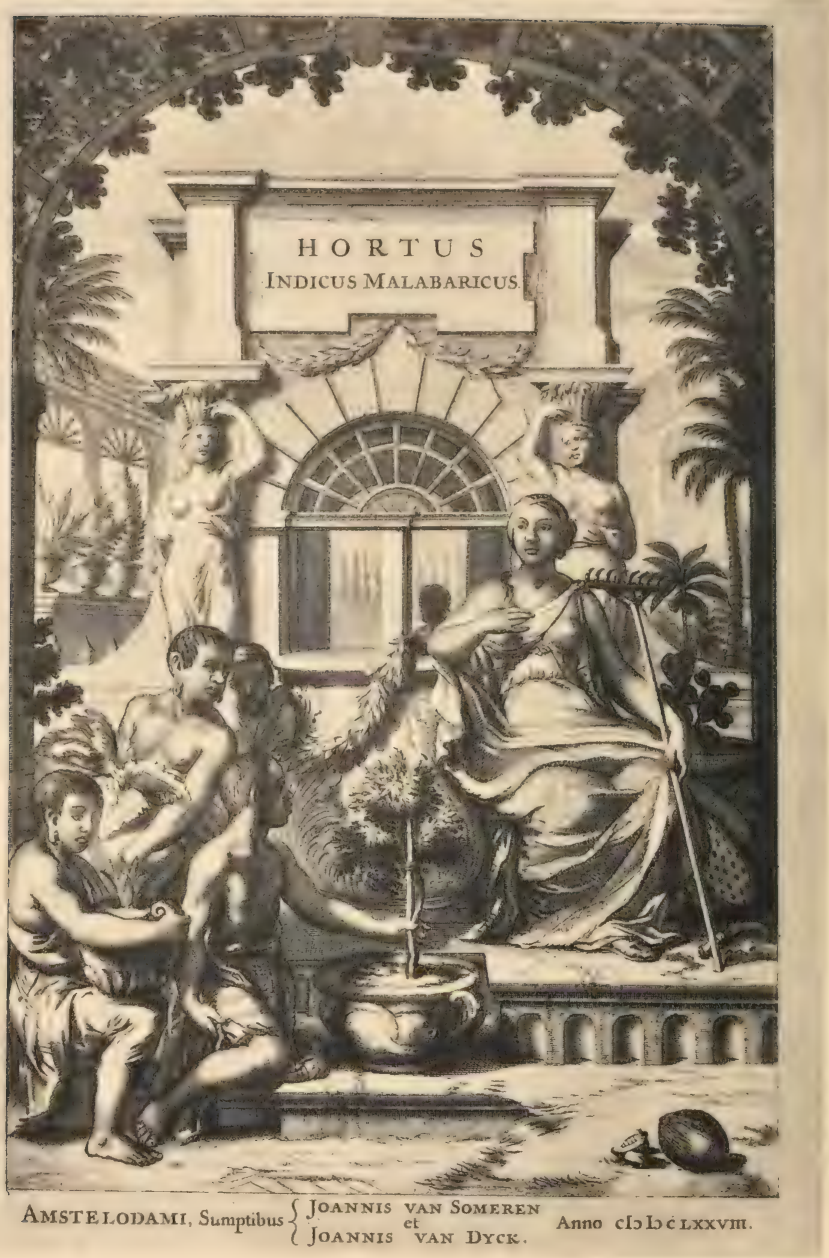




\section{INDISCH NATUURONDERZOEK}

\section{ACADEMISCH PROEFSCHRIFT}

TER VERKRIJGING VAN DEN GRAAD VAN DOCTOR IN DE PLANT- EN DIERKUNDE AAN DE RIJKS-UNIVERSITEIT TE UTRECHT, OP GEZAG VAN DEN RECTORMAGNIFICUS Dr. H. SNELLEN JR., HOOGLEERAAR IN DE FACULTEIT DER GENEESKUNDE, VOLGENS BESLUIT VAN DEN SENAAT DER UNIVERSITEIT, TEGEN DE BEDENKINGEN VAN DE FACULTEIT DER WIS. EN NATUURKUNDE, TE VERDEDIGEN OP

DINSDAG 23 MAART 1915, DES NAMIDDAGS TEN 4 URE, DOOR MARIUS JACOB, SIRKS GEBOREN TE ROTTERDAM 


$$
\begin{aligned}
& -65 \\
& 1915
\end{aligned}
$$


AAN MIJN MOEDER

IN DANKBARE HERINNERING AAN MIJN YADER 

De aranleiding tot het samenstellen van dit procfschrift is siweest de prijsvraag, woor het jaar I9I2 uitgeschreven door hit voormalig Koloniaal Musenm te Haarlem, hiidende: "Een biknopte geschiedenis van de beoefening der natumwetenschappen in de Nederlandsche Koloniën". Bij den overgang van het Koloniaal Museum aan het Koloniaal Institunt, werd de prijsuraag door dit laatste overgenomen met verlenging van de insendingstermijn tot I Famuari 19I4.

Het ecnig ingckomen antwoord op deze prijsvraag werd door de jury een bekroning waardig gekeurd.

In omgewerkten vom, warbij dankbaar gebmik gemaalit werd wan de wenken der beoordeclingscommissie (Prof. Dr. F. A. F. C. Went, Prof. Dr. Max Weber, Prof. Dr. P. van Ronburgh, Dr. R. D. M. Verbeek en Dr. J. Dekker) en van de Hecren Prof. Dr. A. A. Plele en Dr. J. P. V. D. SToK, bicd it mijn arbeid thans aan de faculteit als procfschrift aan.

De Raad wan Beheer van het Koloniaal Institunt en in het bijzonder sijn Algemeene Secretaris, Prof. Dr. H. P. WIIsima, moge overtuigd sijn van mijn erkentelijkheid voor de uitgaie s'an mijn proefsclurift.

Voorts breng ik mijn dank aan allen, die mij bij hat wrokrijgen 


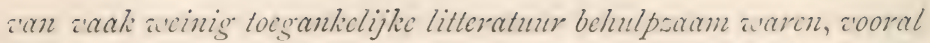

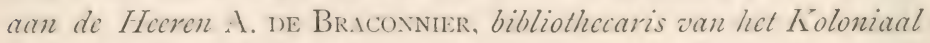
Institunt on I. J. VERWINEN, bibliothccaris van Teylers bockerij. Het is mij ecn behocfte hier cen aroord aan toe te voegen tot hen, aun wic it mijn wetenschappelijke opleiding te danken heb. Behalie aan de Hoogleoraren der Leidsche Universiteit, wier colleges it bijwoonde cn s'an wire it direct of indirect leiding ontving, wil ite niet nalaten, hier aan Dr. J. P. Lotsy to Haarlem hartelijk dank te segren woor de welwillendheid, die hij me na het verlaten der Universiteit bctoond heeft en voor de gastorijheid, die ite steeds in zijn procftuin of op sijn studeerkamer genieten mocht.

Dc baverking wan dit proefschirift heeft mij in de cerste plaats met $U$, hoogseachte promotor. IVExT, in aanraking gebracht. Sta mij toe hier officied mijn warmen dank wit te spreken voor $U_{w}$ hulp on Uiv bereidvaardigheid, mijn promotor to willen sijn. 


\section{I $\mathrm{N} \mathrm{HOU} \mathrm{D.}$}

INLEIDING .

HOOFDSTUK I: BaAnEREKERS .

HOOFDSTUK II: G. E. Rumphius . . . . . . . . . . . . . . 25

HOOFDSTUK III: DE AChtTIENDE EeUI (I702-I8I6). . . . . . . 62

HOOFDSTUK IV: De NATUURKUNDIGE COMMissie(I8I6-i850). OpKonst

VAN 'S LANDS PLANTENTUIN . . . . . . . . . . . . . . . S6

HOOFDSTUK V: F. IV. Junghuhn. . . . . . . . . . . . . Itr

HOOfdStuk VI: Algemeene natudrwetenschap Na I850.. . . 154

HOOFDSTUK VII: DE VERdERE ONTIIKKELING VAN 'S LANDS PLANTEN-

TUIN EN HET PLANTKUNDIG ONDERZOEK NA I850 . . . . . . . 183

HOOFDSTUK VIII: DE STUdie DER DIERENWERELd NA I850 . . . . 216

HOOFDSTUK IX: Scheikundige ARbeid NA I850 . . . . . . . . 227

HOOFDSTUK X: Geologische ontdekkingen Na I850. . . . . 240

HOOFDSTUK XI: NATUURKUndige aARdRiJkSKUnde Na I850. . . 254

HOOFDSTUK XII: Toegepaste natuUriwetenschap. Het proefSTATIONWEZEN . . . . . . . . . . . . . . . . . . 265

HOOFDSTUK XIII: De west-indische bezittingen . . . . . . . $2 \$ 4$ REGISTER VAN PERSOONSNAMEN . . . . . . . . . . . 205 



\section{N L E I D I N G.}

Een verheugend verschijnsel in onzen tijd is het, dat overal. op elk gebied, een verlangen naar historische kennis ontwaakt, naar het begrijpen en daardoor waardeeren van den arbeid onzer voorgangers. Zoo volkomen juist zijn de woorclen van den physicus Volkuans: ,Je älter man wird, destomehr schätzt man überhaupt Geschichte. Man uiberschätzt nicht in dem Masse, wie die Jugend, die Gegenwart, man betrachtet bereits die Entwicklungsepoche, an der man selbst Teil hat, als einen Abschnitt kommender Geschichte".

In twee richtingen kan deze belangstelling in den ontwikkelingsgang onzer wetenschappen zich uiten: diepgaande geschiedkundige navorsching, archief- en bronnenstudie, op welk gebied wij voor het Indisch natuuronderzoek dankbaar moeten zijn aan mannen als Greshoff, Treli en H. J. Vetil, maar daarnaast ook overzichtswerk, samenvattend het gansche gebeurde op een min of meer uitgebreid veld van onderzoek. Weemoedig stemt het ons te bedenken, dat de beste kenner van de geschiedenis der natuurwetenschappen in Indië, Matrits Gresiroff, niet meer onder ons vertoeft, dat zijn werkkracht niet meer in staat geweest is, een overzicht als dit over de studierichting, die zoo geheel zijn liefde had, te geven. Want niemand had met meer 
INLEIDING.

warmte en meer gloed dit onderwerp kunnen behandelen; waar Greshoff een levensbeschrijving gaf, daar stond de levende persoon voor ons, daar gevoelden wij mee met Kunl en Van Hasselt hun gewaarwordingen in onherbergzame streken van Preanger en Banten, daar werden wij doordrongen van het edele en bewonderenswaardige in een persoonlijkheid als Nicolaas Witsen.

Het evenwicht tusschen de twee elkaar steeds tegenwerkende krachten: volledigheid en beknoptheid, is een in hooge mate wankelbaar evenwicht; de minste uitwijking kan het verstoren. Ik heb in de volgende bladzijden getracht, het zoo goed mogelijk door alle tijden heen te bewaren; ongetwijfeld zal door menig ander hier en daar, vooral in de nieuwere geschiedenis, een eenigszins andere opvatting hieromtrent gehuldigd worden; individueele waardeering van feiten en personen is hierbij een doorslaggevende factor.

Een uitvoerige verdediging van de stofverdeeling te geven, lijkt mij te dezer plaatse overbodig en ongewenscht. Slechts enkele punten wil ik hier kort toelichten.

In de eerste plaats werd als aanvangsjaar door mij gekozen het begin der zeventiende eeuw; dit neemt niet weg, dat ook in de zestiende eeuw door de Hoctuans, door Hurgen van Linschoten, wiens ,Itinerario, Voyage ofte schipvaert... naar Oost- ofte Poortugaels Indiën", door de Linschotenvereeniging thans in ruimer kring bekend is, belangrijke astronomische en cartographische arbeid verricht werd, maar toch kunnen wij dit niet tot het systematisch natuuronderzoek rekenen.

Tot 1850 , het jaar waarin de kwijnende Indische Natuurkundige Commissie ontbonden werd, leek een chronologisch algemeen overzicht het meest gewenscht; tot dat jaar vormden alle natuurwetenschappen in zekeren zin één geheel, terwijl in de tweede helft van de negentiende eeuw ieder der verschillende 
takken van natuuronderzoek zijn eigen weg ging en hierdoor een afzonderlijke behandeling vereischt werd. In het bijzonder het zeer recente werk, als dat der proefstations, is nog te jong, om een objectief oordeel mogelijk te maken.

Ten derde is de omgrenzing van het begrip natuurwetenschap voor verschillende omschrijvingen vatbaar; $m$. i. is hiervan de meest juiste de meening, in de wet op het Hooger Onderwijs gehuldigd, waarbij tot natuurwetenschappen gerekend worden: astronomie en meteorologie, natuurkunde en scheikunde, plant. en dierkunde, pharmacologie, geologie en palaeontologie, met inbegrip van haar toepassingen, voor zoover deze uit natuurwetenschappelijk oogpunt van beteekenis zijn. Topographie, mijnwezen in engeren zin, ethnographie en de zoo nauw verwante anthropologie zijn ongetwijfeld studievakken van groot belang voor onze koloniën, maar vallen geheel buiten het aldus omschreven gebied der natuurwetenschappen.

Een overzichtswerk als dit wijst in het bijzonder op de fouten, die er gemaakt zijn, op de groote gedeelten, die er in onze koloniale natuurstudie nog ontbreken en op de ruime velden, die daar in het verre Oosten wetenschappelijk nog te ontginnen zijn. Maar terecht zegt VAN GoRkom in zijn Scheffer-biographie: „De geschiedenis heeft geen waarde, zoo wij haar beteekenis niet doorgronden, en ons daarnaar niet gedragen". 


\section{HOOFDSTUK I.}

\section{Ba a n b rekers.}

De eerste helft der zeventiende eeuw was geen tijd van rust voor onzen Oost. De opkomende en in bloei steeds meer toenemende Oost-Indische Compagnie was nog pas meester over een klein gedeelte van den Maleischen Archipel en streefde er met alle macht naar, dit deel te vergrooten, zooveel in haar vermogen lag. Het gevolg hiervan was, dat zij en haar belangen de volle toewijding van haar ambtenaren vergden; de Compagnies-zaken namen hun geheele aandacht in beslag. $\mathrm{Zij}$ konden, hoe gaarne sommigen van hen het misschien ook wilden, zich niet met natuuronderzoek bezighouden; de Compagnie vorderde ander werk van hen, oorlogsbezigheden in de eerste plaats; voor de ,werken des vredes" was hun tijd niet bestemd. De belangstelling in de wonderlijke fauna dier tropische gewesten, in de weelderige flora, in de voor Europeanen zoo vreemde en vaak zoo overweldigende Oostersche natuur, ze was er wel, maar ze kon zich niet uiten. Dat ze er was, blijkt uit de talrijke reisverhalen van dien tijd; steeds worden de meest merkwaardige vertelsels opgedischt over datgene, wat de reizigers in die verre landen van het Oosten 



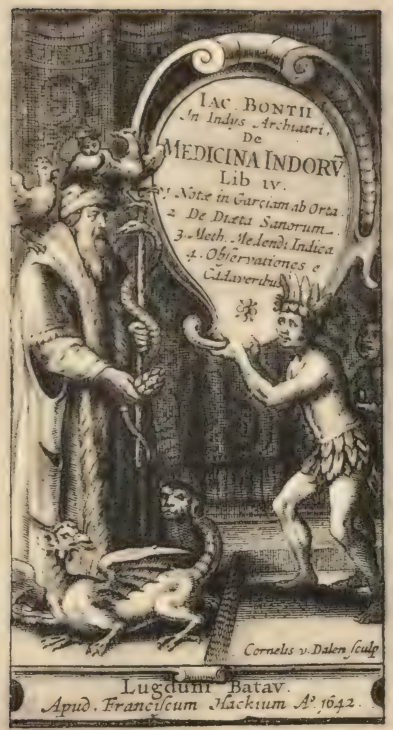


gezien hadden; altijd brachten de Oost-Indië-vaarders voorwerpen mee naar huis, om daaraan in den kring hunner familie de vreemdste fabels vast te knoopen.

Slechts één persoon heeft in dien tijd onze koloniën bezocht, die zich met zulke fantastische verhalen niet tevreden stelde, die, zooveel hij kon, trachtte te weten te komen, wat juist was in die vertelsels omtrent tropische natuurvoortbrengselen en wat te danken was aan de overrijke fantasie der zeevaarders en inlanders. Die persoon was JACoвts BoNtics, lijfarts van Jali Pieterszoon Koen. Ongetwijfeld had Bontics, door zijn opleiding aan de Leidsche Universiteit, door zijn afstamming uit een geleerde familie, veel voor op de overige ambtenaren der Compagnie; dit vermindert zijn verdiensten niet. Bontu's was een man van een buitengewone werkkracht, van een onbluschbare belangstelling in alles, wat de natuur hem bood, niet alleen tijdens zijn verblijf in de tropen, maar ook reeds in den tijd, dien hij in Holland doorbracht.

De gewezen Gouverneur-Generaal Jan Pieterszoon Konx vertoefde sinds 1623 in het vaderland en was bezig zooveel mogelijk welgestelde gezinnen te bewegen, zich in de koloniën te gaan vestigen. De nieuwgestichte stad Batavia moest bevolkt worden; op de eilanden, Ambon b.v., zouden de Hollanders heel wat aan invloed winnen, als er hier en daar kolonies van Hollandsche gezinnen bestonden. Zooals eigenlijk vanzelf spreekt, zocht Koen, die voornemens was, naar Indië terug te gaan, ook iemand, bereid hem te vergezellen, en dan de gezondheid van Batavia's inwoners te verzorgen. Wie was daarvoor beter geschikt dan JAcorus Bontius, Medicinae Doctor, een man, dic behalve een groote medische kennis, ook een voorliefde voor plantkunde bezat, waardoor hij zich met de inlandsche plantaardige geneesmiddelen spoedig vertrouwd kon maken? Al mogen de resultaten van Bontius' natuurwetenschappelijk werk, 
vergeleken met die van latere onderzoekers, niet zeer groot zijn, het feit, dat hij de eerste was, die zich heeft toegelegd op een systematische beoefening der natuurwetenschappen in onze koloniën, rechtvaardigt volkomen, dat wij hier iets omtrent zijn leven meedeelen, wat wij ontleenen aan de uitvoerige biographie door Dr. Swaving ${ }^{\mathrm{x}}$ ).

Jacobus Bontius was de jongste zoon van den Leidschen hoogleeraar Gerardus Bontius, die bij de stichting der Hoogeschool tot hoogleeraar benoemd, dit ambt tot zijn dood, 15 September I 599, heeft bekleed. Gerardus had vier zoons: Renier, JAN, Willem en JACOBUS, die allen in de wetenschap een goeden naam hebben verworven. Reinier was medicus, gaf reeds in I 599 colleges en werd in 1603 aangesteld als hoogleeraar aan de Universiteit: JA.N was eveneens medicus en is geneesheer te Rotterdam geweest; WILLEN was rechtsgeleerde en heeft, na gedurende eenige jaren hoogleeraar te zijn geweest, daarna langen tijd het ambt van schout te Leiden waargenomen. De jongste van het viertal, JACoBus, werd op I 2-jarigen leeftijd (I5 Mei 1604) als studiosus artium liberalium ingeschreven, volgde allereerst de inleidende lessen van zijn broeder REINIER en andere hoogleeraren, om later te gaan studeeren onder leiding van mannen als Petrus Pavius, Aelits Everardis Vorstius en Otto Hecirnius. Van den verderen studietijd van JACoBus weten we niet veel; alleen nog dat hij 22 Juni $1614^{2}$ ) gepromoveerd is tot Doctor Medicinae, en dat hij zich, na afloop zijner studiën, te Leiden als arts vestigde. Bij resolutie

1) C. Swaving, i868. Ter gedachtenis van Jacobus Bontius, M.D. (Natuurk. Tijdschr. v. Ned.-Indië. XXX. p. 285-342).

2) Zie J. E. KRoON, I9I I. Bijdragen tot de geschiedenis van het geneeskundig onderwijs aan de Leidsche Universiteit. (Dissertatie Leiden. 1911). p. 124-125. Naar Dr. KRoon mij welwillend mededeelde, is deze datum door hem ontleend aan de Acta Senatus der Leidsche Universiteit. Dr. Sivaving noemt den promotiedatum onbekend. 
van de „Heeren Zeventienen" van 24 Augustus I626 werd JAcobus Bontius aangesteld als „Doctor, Apotheker en Opzigter van de Chirurgijns in Indie, werwaarts hij met de Vloot van J. P. Koen, ingescheept op 't schip Vianen, den 19 den Maart I627 zeilde, vergezeld van zijne vrouw en kinderen. Zijne vrouw stierf op de reis van het Vaderland naar de Kaap de Goede Hoop" "). Op 13 September kwam Bontuls te Batavia aan. Waarschijnlijk heeft hij spoedig na zijn aankomst in Indië een dienstreis gemaakt naar de Molukken en Timor; indien wij tenminste zijn verklaring gelooven kunnen, dat hij ,geene wonderen van hooren zeggen verhaalt, maar alleen datgene, wat hij met eigene oogen gezien of met oordeel begrepen heeft; zoodat wij ons niet kunnen voorstellen, dat hij over 'Timor's klimaat of plaatselijke ziekten van Ambon b.v. schrijven zal, zonder op die eilanden geweest te zijn" "). Boxtil's zelf verklaart met nadruk: Scribant alii, quibus ista mens est, miracula ex auditu: Ego, quod hisce oculis et qualicunque meo judicio percepi, vobis spectandum propono ${ }^{3}$ ). - In ieder geval was hij met den aanvang van het eerste beleg van Batavia door Sultan AGENG, den vorst van Mataram (22 Augustus 16283 December 162S) weder in Batavia terug, waar hij verder steeds is gebleven. Hij heeft dus ook het tweede beleg door denzelfden Sultan Ageng (2 I Augustus 1629-2 November 1629) medegemaakt.

Verder blijkt Bontuss in den tijd tusschen deze beide belegeringen gedurende vier maanden ziek te zijn geweest, tenge-

$\left.{ }^{1}\right)$ G. F. Pop, 1868. De Geneeskunde bij het Nederlandsch Zeewezen. Geschiedkundige nasporingen. Zesde stuk. (Geneesk. Tijdschr. v. d. Zeemagt. VI. p. $207-263$ ). p. 233 noot.

Idem. Zevende stuk. (Ibidem VII. p. I-36).

2) C. Swaving, I868. p. 3 or.

3) JAC. Box1ws, 16.42. De medicina Indorum Lib. IV. L.B. apud Franciscum Hackium. Anno 1642. $12^{\circ}$. p. I10. 
BAANBREKERS.

volge van malaria, beriberi en dysenterie; na zijn genezing begonnen zijn tweede vrouw, SARA GErARd, met wie hij inmiddels gehuwd was, en zijn beide zoons aan dezelfde kwalen te sukkelen. Omstreeks dezen tijd schijnt Bontı́s lid van den Raad van Justitie te Batavia geworden te zijn, waarna op I Mei I6zo zijn benoeming tot advocaat-fiscaal, als opvolger van ANTonict VAN DEN HELTEL, gevolgd is. (Resolutie van Gouverneur-Generaal Specx, d. d. I Mei $1630^{1}$ ). Van i 5 October 1630 tot I 8 Januari I63 I nam hij bovendien het ambt van Baljuw van Batavia tijdelijk waar. Nadat zijn tweede vrouw op S Juni 1630 aan cholera overleden was, trad Bontius voor de derde maal in het huwelijk en wel nu met de weduwe van den tijdens het tweede beleg overleden predikant Jormannes Cavallerius. Mogelijk is Bontius den $14^{\text {den }}$ September 163 I voor vast als Baljuw van Batavia benoemd; zeker schijnt dit niet te zijn. IVel heeft hij op dien datum de waardigheid van advocaat-fiscaal neergelegd, in welk ambt hij den 20 en werd opgevolgd door Dr. P. VAlck. Was Bontits misschien met zijn positie te Batavia niet tevreden? Swaving beweert van wel: ,Het is mogelijk, dat Bontus door vlijt en volharding veel goed wenschte te maken, hetgeen hem te Leiden ontbroken had om vader of broeder te kunnen opvolgen in het professoraat of in de praktijk; maar zeker is het, dat hij hier tevreden was met zijne maatschappelijke positie en die niet wenschte te verlaten na Koen's dood ")". (Hoe Dr. Swavixg gedacht heeft aan de mogelijkheid, dat JAcobus, die bij den dood zijns vaders, pas zeven jaar oud was, zijn vader in het professoraat zou kunnen opvolgen, is mij volkomen onbegrijpelijk). Toch is het niet onmogelijk, dat de verhouding

ז) G. F. Pop, I870. Nog iets over JAcobus Bontıus. (Geschiedk. Tijdschr. v. d. Zeemagt. VIII. p. 29-32, en Natuurk. Tijdschr. v. Ned.-lndië. XXXI. p. $28 \mathrm{r}-286)$. p. 29 of 282 .

2) C. Swaving, 1868. p. 299. 
tusschen Bontils en Koen heel wat beter was, dan die tusschen Bontius en Srecx, Koex's opvolger. Het schijnt, dat er in het voorjaar van $16_{30}$ onaangenaamheden tusschen BoNTius en Si'ECX hebben plaats gehad; in ieder geval denkt Bostius in $16_{3} \mathrm{I}$ er sterk over, „een recours te hebben tot het vaderland". En bovendien hoopt hij, door bemiddeling van WALAEL's en van zijn zwager ANGillis, secretaris van Soeterwou, een professoraat te Leiden te zullen krijgen; hijzelf vindt, dat hij dit nu wel verdient: ,hetwelk ik niet en twijfel of sal, door mijne exotica, daar iets in meriteeren; want sonder roem nogthans geseit, zoo en heeft à Costi, noch Monardus, noch de beste van haar allen, Garcias ab Orta, in welke ik ook eenige nota's geschreven heb, in het vierde part zoo veel gedaan, als ik in desen deele gedaan hebbe, daarvan ik gaarne het oordeel van geleerden sal verwachten" "). Echter blijkt uit een op 's Rijks Archief te 's Gravenhage aanwezigen brief van Weesmeesters te Batavia d. d. 29 November 1632 , dat Boxtius aldaar op 30 November I $63 \mathrm{I}$ overleden is, zoodat hy zijn vaderland niet weergezien heeft. Door dezen brief wordt dus het bewijs geleverd, dat het vermoeden van Dr. Swaving op gezag van Valextry: , dat hij den I $4^{\text {den }}$ September tot Baljuw van Batavia benoemd en in het jaar daaropvolgende overleden is" ${ }^{2}$ ), onjuist is, in ieder geval, wat het tweede gedeelte betreft.

Bedenkt men nu, dat Bontius dus maar even vier jaar in de tropen heeft geleefd, dat gedurende dien tijd Ratavia tweemaal een beleg van twee à drie maanden heeft moeten doorstaan, en dat Bontius in den tijd tusschen het eerste en het tweede beleg vier maanden lang ernstig ziek geweest is, dan verbaast men zich erover, hoe het mogelijk was, dat hij in dien korten

s) G. F. Pop, 1870. p. 31 of 284 .

2) C. Sivaving, I $\$ 68 a$. Naschrift tot de levensschets van Jaconus Bontius. (Natuurk. Tijdschr. v. N.-I. XXX. p. $475-477$ ). p. 476 . 
tijd, behalve zijn drukke dagelijksche bezigheden, zooveel heeft kunnen tot stand brengen. Hij werkte dan ook dag en nacht, zichzelf bijna geen rust gunnend; hij wilde aan Heeren Zeventienen laten zien, wat hij kon. Terwijl hij overdag geneeskundige practijk uitoefende, hetzij in de stad, hetzij in het ziekenhuis, en nog tijd vond om in de bosschen rondom Batavia te gaan botaniseeren, gebruikte hij zijn avonden en groote gedeelten van de nachten, om zijn aanteekeningen uit te werken, om alles, wat hij gezien had, nauwkeurig te beschrijven en zijn werk voor de pers gereed te maken. De uitgave van zijn werken heeft Bontuus niet beleefd; een viertal boeken, waarvan het eerste: „Notae in Garciam ab Orta”, het meest belangrijke was, was reeds in het begin van I63I persklaar; zijn broeder Willem, aan wien hij ze, vergezeld van een opdracht, zond, schijnt ze niet terstond te hebben willen uitgeven; pas in 1642 verschenen ze bij Franciscus Hackius te Leiden, welke uitgave in duodecimo, over het algemeen slecht verzorgd was "). De mooiste en meest kostbare uitgave van Bontius' werken is die van de gebroeders Elzevier bezorgd door Gulielmus Piso. In een op Piso's naam staand groot folio werk ${ }^{2}$ ) vinden wij, dat van de veertien boeken een zestal herkomstig zijn van JACOBC'S Bontius, en wel de vier reeds genoemde, in 1642 uitgegeven, werken, die door Bontius zelf voltooid waren, benevens een tweetal boeken: „Historia Animalium en „Historia Plantarum”.

Deze beide werken heeft Bontrus, door den dood overvallen, niet kunnen voltooien, wat om verschillende redenen in hooge mate te betreuren is; vooral omdat Bontius terstond na zijn aankomst in Indië een aanvang gemaakt heeft met op te teeke-

ז) Zie bladzijde 7 noot 3 .

2) Gulielmi Pisonis Medici Amstelaedamensis de Indiae utriusque re naturali et medica Libri Quatuordecim Quorum contenta pagina sequens exhibet .... Amstelaedami. Apud Ludovicum et Danielem Elzeviros. MDCLVIII. (i658). 
nen, wat hij alzoo over inlandsche planten en dieren te weten kon komen, en hij in dien tijd nog niet altijd fabel van waarheid wist te onderscheiden. Terecht zegt Swaving dan ook: „Wij herhalen het, wanneer onze Archiater zijne historia animalium et plantarum, waaraan hij onmiddellijk na zijne komst te Batavia begon te werken, op de pers had gebracht, dan zoude hij, steeds toegenomen in kennis en ervaring, gedurende zijn vijfjarig verblijf alhier, en daardoor minder lichtgeloovig geworden, zonder twijfel veel daarin achterwege gelaten of bepaald verklaard hebben, wat volgens de waarzegging der oude Indische vrouwen, of wat volgens zijne ervaring, geboekt is" ").

$\mathrm{Nu}$ werden zijn geschriften en teekeningen onafgewerkt in handen gesteld van Willex PIso, wiens lichtgeloovigheid aan de betrouwbaarheid dezer uitgave geen goed heeft gedaan. Vandaar een groot aantal tegenstrijdigheden tusschen beweringen in het eerste der zes door PIso uitgegeven boeken: „De conservanda valetudine", een werk over het voorkomen van ziekten, en meeningen uit zijn ,Historia Plantarum”. PIso heeft alles wat Bontius in dit laatste werk mededeelt, voor goede munt opgenomen en nog met eigen aanteekeningen verrijkt. Bovendien heeft hij zich de vrijheid veroorloofd, uit het reeds genoemde werk: "Notae in Garciam ab Orta" groote gedeelten weg te laten, over zeer belangrijke planten handelend, o.a. over den betelnoot, over de tamarinde, en over de curcumawortel. Slechts enkele onderwerpen, die Boxtics bespreekt, wil ik hier noemen: in "Liber quintus: de Quadrupedibus, Avibus et Piscibus" vertelt hij over eetbare vogelnestjes, over den vliegenden hond, over de tegenwoordig uitgestorven Dodaers of Dronte, over den merkwaardigen Molukkenkreeft Limulus, enz.; terwijl hij in "Liber sextus: de Plantis et aromatibus”, hoofdstukken wijdt aan de thee, slijmappelen, enz. Zooals reeds

r) C. SWAving, I868. p. 328 . 
grezegd, is het zeer te bejammeren, dat Bontius, ouder en wijzer geworden, de uitgave dezer beide boeken niet meer zelf heeft kunnen bezorgen; merkwaardig en vermeldenswaard blijven ze. ondanks hun niet volkomen betrouwbaarheid, als monumenten, getuigend van vlijt en werkkracht, van een eerste poging, om de tallooze wonderen, die de tropische natuur onzer koloniën oplevert, nader te leeren kennen en te beschrijven.

Buntus, de baanbreker, had niet onmiddellijk een opvolger. W'el werd reeds in zijn tijd door enkele personen, vooral reizende geneesheeren, hier en daar materiaal verzameld, en dan in het vaderland bewerkt, maar geen van hen legde er zich speciaal op toe, de flora en fauna in de tropen zelf te bestudeeren. Zoo vertoefde de arts Pallus Hermann in de jaren 1630-i640 op Ceylon en verzamelde daar een groote hoeveelheid herbariummateriaal, dat door hemzelf tijdens zijn professoraat te Leiden bewerkt werd en waarvan de uitgave door William Sherard bezorgd werd. Hermany stierf te Leiden in 1695; de uitgave zijner werken heeft hij niet beleefd ${ }^{\mathrm{I}}$ ).

Het eigenlijke natuuronderzoek in Oost-Indië stond dus na Boxtus voor geruimen tijd stil. Pas na $1670 \mathrm{kwam}$ er nieuw leven, zoodat de geschiedenis van het natuuronderzoek der tropen toch nog kan bogen op een drietal groote mannen na

1) $\mathrm{Na}$ zijn dood, in 1699 , verscheen pas het door SHERARD verzorgde werk: „Paradisus Batavas" met II I platen. In I II7 volgde hierop een tweede deel: "Musaeum Zeylanicum", eveneens door de goede zorgen van Sherard. Op het door Hermann verzamelde materiaal van Ceylonsche planten berustte voor een groot deel nog het in 1737 door den Amsterdamschen hoogleeraar JoHANNes Burman uitgegeven kwarto-werk: „Thesaurus Zeylanicum”, terwijl ook LinNaEus in zijn "Flora Zeylanica” een dankbaar gebruik maakte van alle tot nog toe gepubliceerde, alsook van de nog onbeschreven verzamelingen van Hermans. Voor een lijst van Hermaxx's planten zie men "Journal of Botany", 1887. In alle genoemde werken, die op Hermaxis verzamelingen gebouwd zijn, wordt de soortsdiagnose nog als een soortsnaam gebruikt; de binominale nomenclatuur had nog geen ingang gevonden. 
Bontius. Het zijn Engeldrechit Kaempfer, Hendrik Auriany van Reede tot Drakestein, en George Everhard Rlmilils. Weliswaar hebben de eerste twee voornamelijk hun sporen verdiend in landen, die tegenwoordig niet meer tot onze koloniën behooren, maar toch mogen hun namen in een geschiedenis als deze, hoe beknopt ook, niet ontbreken.

Een uitvoerige levensbeschrijving van KAEMPFER geeft ons DE Roswy in zijn: „Variétés Orientales" ${ }^{\mathrm{I}}$ ), naar welk werk wij voor verdere levensbijzonderheden verwijzen. Slechts het belangrijkste daaruit, voornamelijk voorzoover het onze tegenwoordige koloniën betreft, willen wij hier vermelden. Na tal van omzwervingen door Noord-Europa (hij studeerde o.a. medicijnen te Hameln, geschiedenis en philosophie in Hamburg en Lubeck, en natuurwetenschappen in Königsberg) kwam KaEMPFer eindelijk in Stockholm te land; ondanks alle pogingen, hem daar te houden, sloot hij zich als secretaris aan bij een Zweedsch gezantschap, dat naar Perzië gezonden werd, teneinde zoo mogelijk handelsbetrekkingen tusschen beide landen in het leven te roepen; hij vertrok met dit gezantschap den 26en Maart ${ }_{2} 6 \$_{3}$ (oude stijl) over Rusland naar Perzië. Pas 29 Maart ${ }_{168} 4$ in Ispahan, de toenmalige hoofdstad van Perzië aangekomen, bleef de Zweedsche missie hier bijna twee jaar (DE Rosny vermeldt verkeerdelijk twee maanden), welke tijd door KAEMPFER aangenaam werd doorgebracht met het bestudeeren der omgeving van Ispahan. Met leede oogen zag KaEmprer de toebereidselen voor het vertrek maken; hij besloot het gezantschap vaarwel te zeggen en zich als geneesheer in dienst van de O.-I. Compagnie te begeven. Met dat doel verliet hij 2 I November I $_{6} 8_{5}$ Ispahan, kwam te Bender-Abassi, en scheepte zich, na aldaar een ernstige ziekte te hebben doorgemaakt, in Juni 1688 op de

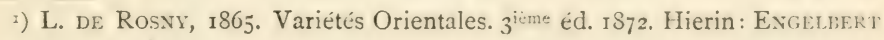
KAEMPFER. p. 98-I22. 
Hollandsche vloot in. Daarna bezocht hij o.a. Sumatra, en vertoefde van midden September 1689 tot 7 Mei 1690 te Batavia. Gedurende dezen tijd heeft hij zich met ijver toegelegd op de bestudeering der Javaansche flora; het nabijgelegen eiland Edam, waar behalve Javaansche, ook een groot aantal uitheemsche planten gekweekt werden, bood hem hiertoe een uitstekende gelegenheid. Jammer genoeg is van de waarnemingen, die KAEMPfER in dezen tijd gedaan heeft, niets bekend; onder de manuscripten die bewaard zijn, en zich tegenwoordig in het British Museum te Londen bevinden, afkomstig uit de rijke handschriften-verzameling van Sir Hans Sloane, zijn er geen, die waarnemingen uit ons Indië bevatten. De meest bekende werken van KAEMPFEr zijn de „Amoenitates exoticae”, handelend over land en geschiedenis van Perzië en zijn: "Geschichte und Beschreibung von Japan", pas in 1777 in het origineel uitgegeven te Lemgo, zijn geboorteplaats ${ }^{\mathrm{x}}$ ). Van Batavia vertrok KaEmpfer naar Japan, waar een tweejarig verblijf hem in staat stelde, het bovengenoemde groote werk over dat land te schrijven. Vermeldenswaard is verder nog, dat hij na zijn terugkomst in Europa, in 1692 te Leiden gepromoveerd is tot Doctor Medecinae. KaEMPFER overleed op 65-jarigen leeftijd te Lieme bij Lemgo in Westfalen, op den 2 den November I7 I6.

Van geheel anderen aard, en voor ons Hollanders van meer belang, is het werk van Hendrik AdriaAn van ReEde tot Drakestein. Merkwaardig is het, dat zijn naam in Van Hoëvell's "Geschiedkundig overzigt van de beoefening der Kunsten en Wetenschappen in Neêrlands-Indië" ${ }^{2}$ ) in het geheel niet aan-

I) Vertalingen van dit werk hadden reeds veel vroeger het licht gezien : o.a. in 1727 een Engelsche, in 1728 een Latijnsche, in 1729 een Fransche en een Hollandsche.

2) W. R. van Hoevell, 1839. Geschiedkundig overzigt van de beoefening der Kunsten en IVetenschappen in Neerlands Indië. (Tijdschr. v. Ned.-Indie. $2^{\mathrm{e}}$ Jrgng. 1839. $2^{\mathrm{e}}$ Deel. p. I-115). 



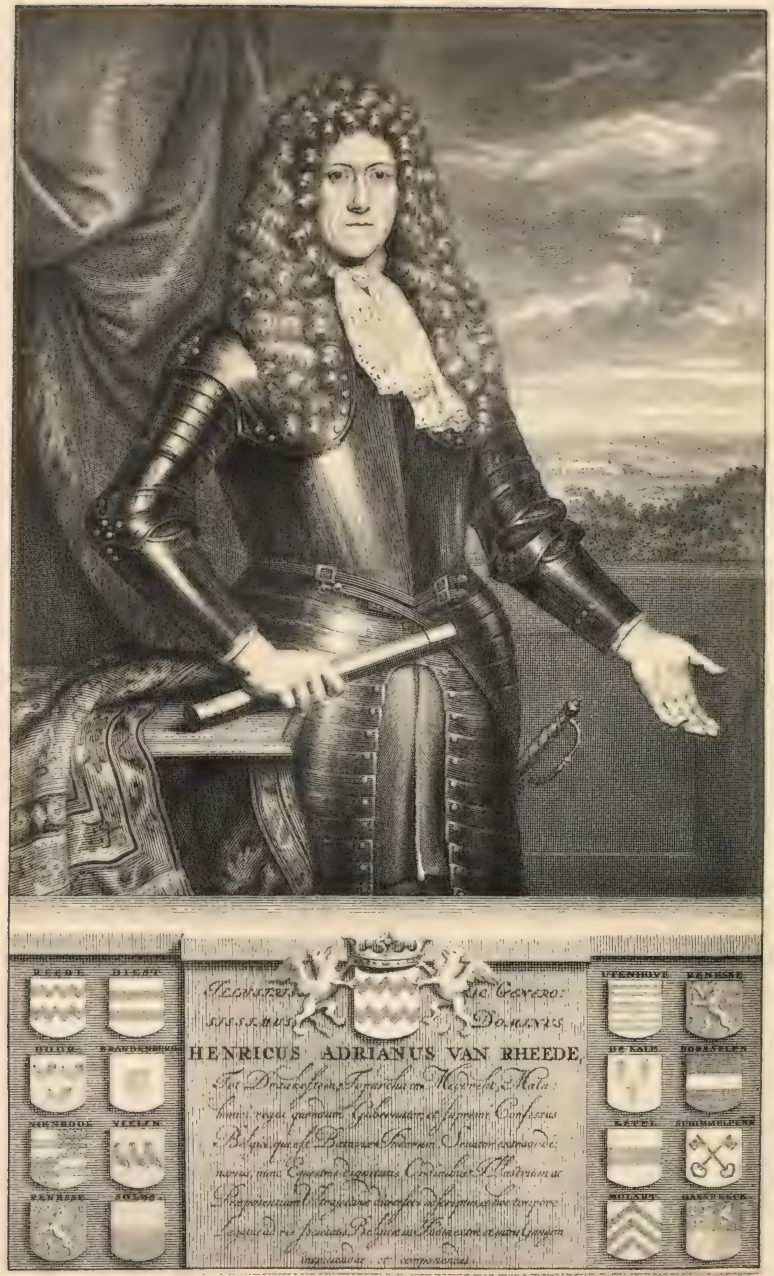


getroffen wordt; te merkwaardiger hierom, omdat VAN HoEver.. ook Bontius' naam verzwijgt en als natuuronderzoekers in onze koloniën alleen, voor zoover de zeventiende eeuw betreft, noemt Kaempfer en Rumphils, beiden Duitschers. De beide Hollanders Bontius en VAN Reede tot Drakestein achtte hij blijkbaar niet belangrijk genoeg, hoewel ze m. i. beiden volkomen opwegen tegen KAEMPFER. Ook het arbeidsveld van VAN ReEde ligt, zooals reeds gezegd, voor het grootste deel buiten onze tegenwoordige koloniën; toch moeten wij, ter wille van de volledigheid, zijn werk hier bespreken ${ }^{\mathrm{T}}$ ).

Afstammeling uit een zeer oud geslacht in de provincie Utrecht, werd H. A. van ReEde tot Drakestein geboren in de buurt van Utrecht, waarschijnlijk op het slot Drakestein in het begin van 1637 . Zijn moeder stierf zeer kort na zijn geboorte, in Februari 1637 , terwijl hij op driejarigen leeftijd zijn vader verloor. De elf kinderen, van wie Hendrik AdriaAn dus de jongste was, kwamen ten laste van de familie, daar de finantiëele omstandigheden der weezen niet schitterend waren. De oudste vijf jongens werden deels voor het leger opgeleid, deels voor page bij een of andere hofhouding. De jongste, bestemd voor de marine, heeft van zijn veertiende jaar af buiten het vaderland rondgezworven, en kwam op 20-jarigen leeftijd als adelborst in dienst bij de O.-I. Compagnie. Hij heeft zich in den dienst goed onderscheiden, zóó zelfs, dat reeds in ${ }^{166_{7}}$ de Gouverneur van Ceylon, de latere Gouverneur-Generaal VAN Goens, hem bij zijn meerderen aanbeval voor de niet gcringe waardigheid van Gouverneur van Malabar. In dat jaar heeft de Gouverneur-Generaal hiertoe nog niet kunnen besluiten; twee jaar later werd de Gouverneur van Malabar, VAN DER

1) Zie de uitvoerige biografie van VAN Reede: P. J. Veth, i 887 . Hexdrik Adrianan van Reede tot Drakestein. Gids $5 \mathrm{I}^{\mathrm{e}}$ Jrgng. I887. III. P. 423-475 en IV p. $113-16 r$. 
Dussen, verplaatst, en VAN REEDE als zijn opvolger aangewezen. Tegelijkertijd werd het Commandement van Malabar onttrokken aan het gezag van den Gouverneur van Ceylon en tot een zelfstandig Commandement gemaakt.

Het voorrecht, op twee-en-dertig jarigen leeftijd Gouverneur van Malabar te zijn, was waarlijk iets buitengewoons. Weliswaar was de bezoldiging niet in overeenstemming met de statie, clie de Gouverneurs te voeren hadden. Zij waren in hun land oppermachtig; zij stonden onmiddellijk onder den GouverneurGeneraal, maar waren door den grooten afstand van Batavia vrijwel aan alle oppergezag onttrokken. Niemand in het Commandement had tegen den Landvoogd iets in te brengen; de leden van den Raad waren volkomen van hem afhankelijk; alleen de Opperkoopman, het hoofd van den handel, en de Kapitein, het hoofd van het leger, zouden in samenwerking met den Raad, iets tegen den Gouverneur kunnen uitrichten; daar echter de Raadsleden over het algemeen een niet geheel zuiver geweten hadden en de Landvoogd volkomen van hun tekortkomingen op de hoogte was, lieten ze alles bij het oude; ze zouden immers tóch aan het kortste eindje trekken. Zoodoende was de geheele Raad afhankelijk van den wil des Gouverneurs, en waren zijn leden niets dan speelpoppen. Of VAN REedE als Gouverneur van Malabar van zijn macht misbruik gemaakt heeft - iets, wat in die dagen een zeer gewoon verschijnsel was - waag ik niet te beslissen; wel heeft zijn vroegere chef en beschermer, VAN GoENs, later, zooveel als in zijn vermogen lag, beschuldigingen tegen hem ingebracht bij de Hooge Regeering te Batavia en hij heeft het daarbij zoover restuurd, dat VAN REEDE in het laatst van 1676 plotseling gedwongen werd zijn waardigheid neer te leggen, en naar Batavia te vertrekken, teneinde deze kuiperijen van den kant zijner rijanden - want VAN Goens was niet de eenige, die naijverig 
was op VAN REEDE's voorspoedige loopbaan - te verijdelen. Dat schijnt hem volkomen gelukt te zijn; tenminste hij werd te Batavia benoemd tot "Raad extraordinaris van India”. Het verluidde, dat VAN Goens bestemd was, den GouverneurGeneraal Maetsuyker op te volgen, en Van Reede koos zeker de wijste partij, toen hij besloot, de komende dingen niet af te wachten en vóór dien tijd naar het vaderland terug te keeren. Dat deed hij dan ook in het einde van 1677 als Vice-Admiraal der retourvloot. In het vaderland aangekomen, vestigde hij zich in de provincie Utrecht, verkreeg hier de Heerlijkheid Mijdrecht, en nam daarna zitting in de Staten. Doch dit verblijf in het vaderland zou van korten duur zijn: na vier jaar ( 16 October I684) werd hij aangesteld als Commissaris-Generaal der OostIndische Compagnie, teneinde een nauwkeurig onderzoek te gaan instellen naar de toestanden in de zoogenaamde „West van Indië" (n.l. Ceylon, Malabar, Coromandel, Bengalen en Suratte), waar de ,morshandel", de verboden handel der Compagnies-beambten, welig tierde. VAN REEDE had volmacht, iederen ambtenaar, dien hij schuldig bevond, af te zetten of te verplaatsen naar eigen willekeur, met dien verstande, dat de Hooge Regeering te Batavia zijn handelwijzen moest goedkeuren, voor zoover het hooggeplaatste ambtenaren betrof. Het schijnt, dat VAN REEDE zich van zijn taak op een al te nauwgezette wijze wilde kwijten; hij trad met te groote gestrengheid op. Toch is het hem niet gelukt, het zoo diep gewortelde kwaad uit te roeien. Bovendien heeft hij zijn reis niet ten einde kunnen brengen; in het laatst van 169 I van Ceylon vertrokken naar Suratte, om hier zijn onderzoek voort te zetten. overleed hij aan boord, den I5den December I69I, aan een ingewandsontsteking. $\mathrm{Na}$ aankomst te Suratte werd het lijk aldaar met groote praal ter aarde besteld.

Hoe heeft nu deze man, staatsman in merg en been, een 
van de hoogste ambten der O.-I. Compagnie bekleedend. iets kunnen doen voor de kennis der natuur onzer toenmalige koloniën? Hij zelf heeft op deze vraag het antwoord gegeven in zijn "Praefatio ad Benevolos Lectores", die het derde deel van zijn standaardwerk: „Hortus Malabaricus” vooraf ging. Het grootste en meest belangrijke deel dezer voorrede kan men vertaald vinden in de reeds genoemde biographie van de hand van Prof. P. J. Veth ${ }^{\mathrm{x}}$ ), terwijl ik hier wil laten volgen, wat Busken HLet in zijn "Land van Rembrand" ") over dit grootsche werk mededeelt : „In den dienst der Compagnie opgeklommen tot Raad van Indië en gouverneur der kust van Malabar, het voormalig rijk der Portugeezen met Goa tot hoofdstad, bezat hij, hoewel een marine-officier zonder wetenschappelijke opleiding, al op zijn veertiende jaar aan boord gegaan, den aangeboren botanischen zin van een geniaal dilettant. Hij is een der Nederlanders geweest, die met niet veel methode, maar met eene des te hartstochtelijker liefde, binnen een bepaald gebied zich op de tropische flora geworpen hebben. Hetgeen hij zelf verhaalt omtrent de wijs, waarop hij aan die honderden fraai uitgevoerde afbeeldingen van boomen, planten en vruchten gekomen is, verraadt den onverzadelijken beminnaar eener onbekende, geheimzinnig weelderige natuur".

,Eerst klampt hij te Koetsjin, in zijn gouvernement van Malabar, pater Matthaecs van Sint-Jozef aan; een bejaard roomsch zendeling en karmelieter monnik, afkomstig uit Napels, die al sedert langen tijd, zoo goed en kwaad het ging, met Indische botanie zich heeft beziggehouden. Daarna krijgt hij, hoewel maar voor eene poos, een Nederlander te pakken: Paulus Hermannus, geneesheer in dienst der Compagnie, weldra

г) P. J. VETh, 1887. III. p. 460-473.

2) Conrad Busken Huet, i886. Het land van Rembrand. Tweede druk. Haarlem, I886. II, 2. p. $69-70$ 
te Leiden tot Professor benoemd, en naar het moederland terur srekeerd. (Zie blz. 12). Een gezegend toeval voert eindelijk naar Koetsjin - onder de Nederlanders werd Goa door Koetsjin vervangen - een jong gereformeerd predikant, Johandes CAsearius, in de wetenschappelijke botanie even onbedreven als VAN REEDE zelf, maar bezield met eene even vurige belangstelling".

"Nu heeft hij iemand bij de hand, die in vloeijend latijn, bij de te vervaardigen afbeeldingen, den onmisbaren tekst schrijven kan. De voorraad dier beschrijvingen groeit dagelijks aan. De Malabaren zijn een volk met eene beperkte, maar eeuwenheugende beschaving; en weldra heeft de Hollandsche Gouverneur uit hun midden vier teekenaars gekozen. welke hij aan zijne dienst verbindt, en die hem overal vergezellen. Onder zijne leiding vormt zich een kollegie van vijftien of zestien geleerde Bramanen, dienst doende als adviseurs. Er wordt aan alle inlandsche vorsten en hoofden geschreven om medewerking: en daar deze lieden niets liever verlangen, dan bij den gouverneur uit de verte hunne opwachting te maken, zenden zij vrachten exemplaren in. De specimens worden door de Bramanen onderzocht, geschift, geklassificeerd: alles naar de regelen der oude en overgeleverde inlandsche kennis. Somtijds rijzen er tusschen die vakmannen wetenschappelijke geschillen, die echter nooit tot oneenigheid leiden. Het treft integendeel VAN REEDE, dat er in dezen kring gedebatteerd wordt met eene voorbeeldige hoffelijkheid en humaniteit".

„Enkele boomen en planten zijn zoo zeldzaam, dat er in den loop van een geheel jaar maar één exemplaar van aangebracht wordt. Naar andere wordt door den gouverneur in persoon medegezocht. Hij volbrengt of verzint, namens de Compagnie, zendingen naar het binnenland, rivieropwaarts en doet bij deze tochten door een paar honderd Malabaren zich vergezellen, die, 
zoo vaak de stroom een bosch aandoet, door hem aan land gezet, en de boomen ingejaagd worden. Van den buit, dien zij aan boord brengen, worden aanstonds door de nooit ontbrekende teekenaars afbeeldingen gemaakt, en Ds. Casearius draalt niet met zijne ontwerp-beschrijving. Op die wijs komt de eenmaal beroemde Hortus Malabaricus tot stand".

Ja, zoo kwam het handschrift van den Hortus Malabaricus tot stand, maar daarmee was het einddoel van VAN REEDE niet bereikt; op den weg, die voor hem lag, wachtten hem nog heel wat meer moeielijkheden, dan hij totnogtoe overwonnen had. Jammer is het, dat Busken HuEt het niet noodzakelijk geoordeeld heeft, ook de wijze van publicatie van den Hortus Malabaricus te beschrijven; zeker zou dan de indruk, dien zijn woorden op den lezer maken, niet minder zijn. Nu is het beeld, dat wij van de door VAN REEDE overwonnen bezwaren krijgen, onvolledig en vaag. Volkomen juist zegt $\mathrm{VETH}^{\mathrm{I}}$ ): „Maar, toonde hij zich een uitstekend man in het verzamelen der gegevens voor zijn Hortus Malabaricus, niet minder legde hij eene zelfopofferende volharding aan den dag bij de uitgave van dit werk, waarbij hij opnieuw met groote zwarigheden te worstelen had".

De plantkunde was in den tijd van VAN REedE nog in den volsten zin des woords een beschrijvende wetenschap; de kruidboeken der geleerden bevatten voor het grootste deel af beeldingen en beschrijvingen van de waargenomen planten; oorspronkelijk was hun doel, de geneeskrachtige planten, voorkomende in de werken van Theophrastus, Plinius, Dioscorides, terug te vinden en opnieuw als medische kruiden in gebruik te nemen. Langzamerhand werden zoodoende de eerste schreden op het glibberige pad der systematiek gezet; men had een classificatie der beschreven planten noodig en maakte ze. De

₹) P. J. VETH, I887. III. p. 473 . 
groote, reeds door ARISTOTELEs aangenomen, groepen waren deze drie: boomen, struiken en kruiden; aan die indeeling wercl met hand en tand vastgehouden. De verdere indeelingen waren meestal geheel afhankelijk van de willekeur der schrijvers: enkele groepen, waarvan de geleerden a. h. w. bij intuitie de onderlinge verwantschap voelden, werden algemeen aangenomen, zooals die der Composieten, der Umbelliferen, der Mossen, e. a. Zoo was de wijze van werken in den tijd van LEoNARd Flchs, die in 1542 zijn ,Historia Stirpium" publiceerde, zoo was het bij Carolus Clusils, wiens ,Rariorum plantarum Historia" in I 576 verscheen, en zoo was het nog in den tijd van VAN REEDE. Wel had de systematiek groote vorderingen gemaakt, wat de kleinere groepen betreft; de hoofdindeeling was zelfs bij de beste systematici uit den voor-Linneaanschen tijd, CASPAR BALHIN en Andrea Caesalpino, nog die in boomen en kruiden. Om een voorbeeld te geven: CLusius' Rariorum plantarum Historia bestaat uit een zestal boeken, waarvan het eerste handelt over boomen, struiken en halfstruiken; het tweede over bol- en knolplanten; het derde over welriekende bloemen, het vierde over reukelooze bloemen: het vijfde over vergiftige, narcotische en scherpsmakende planten, terwijl het zesde een beschrijving bevat van melksapgevende planten, Umbelliferen, Varens, Grassen, Leguminosen, en eenige Cryptogamen.

Dat was ook de systematiek, die VAN ReEne toepaste; in het eerste deel van zijn ,Hortus Malabaricus", uitgegeven in $1678^{\mathrm{x}}$ ), dus voordat VAN REEDE in het vaderland teruggekeerd

1) De volledige titel voorin deel I van VAN REeDE's werk luidt: „Hortus ॥ Indicus || Malabaricus || Continens || Regni Malabarici apud Indos celeberrimi \| omnis generis Plantas rariores || Latinis, Malabaricis, Arabicis et Bramanum Characteribus nominibusque expressas, || Unà cum Floribus, Fructibus et Seminibus, naturali magnitudine à || peritissimis pictoribus delineatas, et ad vivum exhibitas. I| Addita insuper accuratâ earundem descriptione, quâ colores, odores, sapores, facultates, $\|$ et praecipue in Medicinâ vires exactissime demonstrantur. II Adornatus 
was, worden boomen en heesters behandeld, eigenlijk tegen VAN REEDE's zin, daar nu de goede rangschikking verstoord was, doordat nog lang niet alle boomen beschreven en afgebeeld waren. TAN REEDE was van plan eerst nadat hij alle boomen bijeenverzameld had, met de publicatie te beginnen: cloor een misverstand werd in het raderland met het drukken en uitgeven een aanvang gemaakt, zoodra men een behoorlijke hoeveelheid afbeeldingen en beschrijvingen van CASEARILS ontvangen had. De uitgave van het eerste deel werd bezorgd door ARn. VAN SYEN, hoogleeraar te Leiden: aan de volgende deelen werd meegewerkt door Johannes Comielin (2e- I $2 \mathrm{e}$ deel); IV. Ten Rhyae (2e deel); Johannes Mrinikx (3e-5e deel); Theodorts Janszonits ab Almeloreex (6e deel); en Abraham YAN POOT ( $7^{\mathrm{e}}$ - I 2 e deel). Het tiende deel van zijn standaardwerk is het laatste, aan welks bewerking VAN REEDE zelf nog searbeid heeft; het verscheen in 1690 , terwijl het elfde pas in 1692 van de pers kwam, dus na den dood van VAN REEDE, die

|| per || Henricum van Rheede, van Draakenstein || Nuperrime Malabarici Regni Gubernatorem, nunc supremi Consessus apud || Indos Belgas Senatorem Extraordinarium, et primum successorem || loco ordinario destinatum, || et |! JoHANNEM Casearium, Ecclesiast. in Cochin. || Notis adauxit, et commentariis illustravit \| Arnoldus Syen, Medicinae et Botanices in Academia || Lugduno-Batava Professor. I Amstelodami || Sumptibus Joanvis van Someren || et \|Joaxnis vaA Dyck $\|$ Anno MDCLXXVIII.

Op latere deelen worden als uitgevers vermeld: Vidua JOANNIS VAx SOMEREN. Heredes Joannis van Dyck, Henricus et Vidua Theodori Boom.

In 1689 verscheen bij deze uitgevers een vertaling van de eerste twee deelen: ,Malabaarse Kruyd-Hof, Vervattende het raarste slag van allerlei soort van Planten, enz. Bijeenvergaard door Henric van Rheede vas Draakestein. In het Latijn beschreven door JohaNNES CASEARIUS. Met aantekeningen verrijkt door Arnoldus Syen. Vertaalt door Abraham yan Poot. M.D. Anno MDCLXXXIX Tot Amsteldam. Bij de weduwe van Johannes van Somerex, de erfgenamen van Jan van Dick, Henrik Boom en de weduwe van Dirk Boom". Het oorspronkelijke voornemen, van het geheele werk een Hollandsche vertaling uit te geven, schijnt na VAN REEDE'S dood opgegeven te zijn. 
den I 5 den December I69 I stierf. Bezig zijnde met de bewerking van het twaalfde deel, overleed Comelis in I692, zoodat VA. Pоот de eenige medewerker was, ,die”, zooals Vetn het uitdrukt $^{\mathrm{I}}$ ), ,het einde van het werk beleefde ( 1703 ), vermoedelijk met een gemengd gevoel van vreugde en afmatting. Waarschijnlijk schreef hij het woord Laatste deel met groote voldoening op den titel, en daar hij gelegenheid vond, ook op dien titel zelven, rekenschap te geven van het ontbreken van Commelin's aanteekeningen bij plaat i 5 en volgenden, was geen roorrede noodig. Zij bleef dan ook achterwege. Gelukkig echter wordt een algemeen register op de twaalf deelen niet gemist".

Als standaardwerk is de „Hortus Malabaricus" van blijvende waarde al moge Busken Huet spreken van ,eenmaal beroemd" werk, al moge het overtroffen worden door het meer bekende Herbarium Amboinense van den grooten Rumpurs, het is en blijft een werk van buitengewone verdienste. De bruikbaarheid ran het werk voor den tegenwoordigen tijd is zeer vergroot door Hasskarl, die in de jaren $\left.1861^{2}\right)$, $1862^{3}$ ) en $1867^{4}$ ) een sleutel heeft gepubliceerd waarmee men van iedere plant terstond den naam volgens Linneaansche nomenclatuur vinden kan. Enkele voorbeelden, ontleend aan het eerste deel, wil ik hier noemen: de eerste plaat stelt voor een plant, waarvan als Latijnsche naam opgegeven wordt: Tenga; tegenwoordig is ze bekend als Cocos; Bala heet thans Musa; Balam pulli nu Tamarindus.

э) P. J. VETH, 1887. IV. p. 123

2) J. K. Hasskari, 3\$6r. Horti Malabarici clavis nova. (Flora oder Allgem. Botan. Ztg. XLIV. p $40 \mathrm{I}-408,4^{8} \mathrm{I}-488,5+5-55^{2}, 577-584,609-6 \mathrm{r} 6,641-648$. $705-712,737-745)$.

3) J. K. Hasskarl, iS6z. Nachträge und Verbesserungen zu .,Horti malabarici clavis nova". (Ilora XLV. p. $4 \mathrm{r}-4 \mathrm{~S}, 73-\mathrm{So}, 121-12 S, 153-160,187-102$ ).

4) J. K. Hasskarl, 1867. Horti malabarici Rheedeani clavis locupletissima. (Abh. K. Leop-Car. d. A. Vol. XXXIV. 1867. p. I-134). 
BAANBREKERS.

In denzelfden tijd, waarin in het vaderland met ijver gewerkt werd aan de uitgave van den „Hortus Malabaricus”, leefde in ons Indië, op een afgelegen eiland, ver van alle wetenschappelijke centra, de man, wiens werk wij reeds genoemd hebben als waardig tegenhanger, ja als overtreffer van VAN REEDE's arbeid: Georg Everhard Rumphius. 



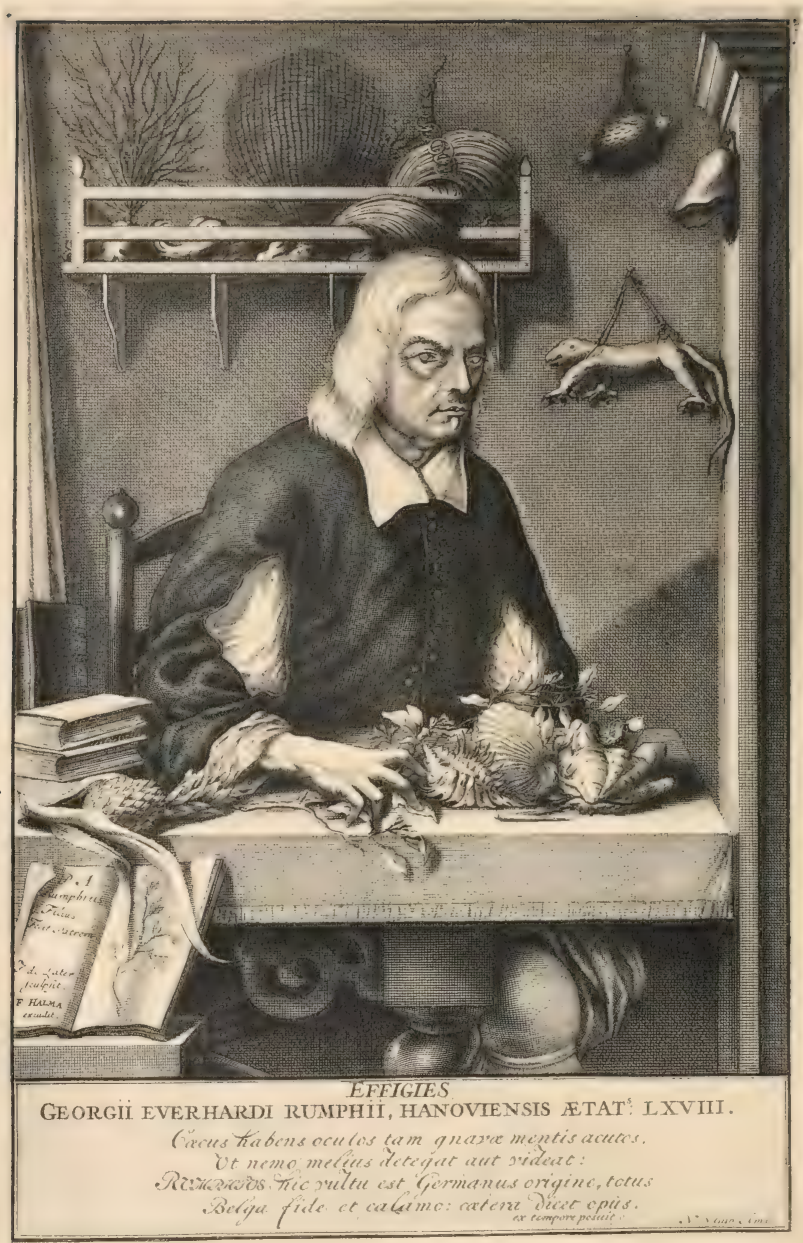




\section{HOOFDSTUK II.}

\section{G. E. Rumphius.}

De „,blinde ziener van Ambon" was, als zoovelen, die zich bij het natuuronderzoek in onze koloniën een welverdienden naam hebben verworven, Duitscher van geboorte, maar ,Hollandsch van hart en taal", verknocht als hij was aan het eiland, waarheen het lot hem gedreven had en waar hij bijna vijftig jaren lang veel leed gedragen en veel vreugde in zijn werk gevonden heeft. Lang, heel lang is het onzeker gebleven, welke stad en welke dag zich op zijn geboorte mochten beroemen en nog altijd is het juiste hieromtrent in nevelen gehuld, al zijn deze wel veel lichter geworden, dan ze voor twintig jaar waren. De meeste argumenten pleiten voor het stadje Hanau aan de Main als zijn geboorteplaats; in ieder geval heeft hij hier reeds vroeg in zijn jeugd gewoond en het gymnasium bezocht. Of was het Münzenberg in de Wetterau? En wanneer? Over zijn geboortedatum geeft hijzelf ongeveer uitkomst in een brief aan den Raad-Ordinaris IsAac de Sint-Martin, en wel door deze, voor ons merkwaardige, dagteekening: „Amboina in 't Casteel Victoria den $15^{\text {en }}$ Maij I69I, zijnde het slot van het $63^{\text {ste jaars }}$ myns ouderdoms". Dus Ruxphius moet kort na 15 Mei 1628 
G. E. RUMPHIUS.

geboren zijn. En uit het gedicht, door den op 7 Juli 1696 overleden Gouverneur van Ambon Nicola as Schagen, op den toenmaals 68-jarigen Rumprus gemaakt, blijkt, dat hij voor 7 Juli 1628 geboren moet zijn. Dus in de tweede helft van Mei of in Juni 1628 zal wel de dag gevonden moeten worden, waarop de groote onderzoeker zijn leven begon ${ }^{x}$ ). Overigens is door het groote aantal biografen, waarop Rumphius zich beroemen mag, al heel raar met zijn geboortejaar gesold; de opgaven 1626 en I627 zijn algemeen; in enkele werken wordt zelfs 1637 of 1676 opgegeven. (Dit laatste in Winkler Prins' geillustreerde encyclopaedie 2 de uitgave, die Rumphits wel in 1669 blind laat worden!)

In een keurig geschreven biographie van den „Indischen Plinius" in de Java-Bode van de hand van PAPAGENo ${ }^{2}$ ), vinden wij de volgende klacht: "Gouden bekers schonk men aan admiraals, met gouden ketenen omhing men terugkeerende landvoogden; voor iemand, die een standaardwerk geschreven, en daarover meer dan de helft van zijn leven gearbeid had, was het voldoende, een zijner kinderen habiel te verklaren tot koopman." En hoe is het tegenwoordig te dien opzichte? Hoevelen zijn er in ons land, die van Vlissinger Michiel de zeeslagen uit het hoofd kunnen noemen, die precies weten te vertellen, wanneer de verschillende Engelsche oorlogen plaats hadden, en die van een man als Rumphius nooit gehoord hebben, of hoogstens zijn naam kennen, omdat een van de schepen der Koninklijke Paketvaart-Maatschappij naar hem genoemd is? En dit, ondanks het bestaan van een prachtwerk, dat in 1902 , ter

I) Zie G. P. Rouffaer en W. C. Muller, I902. Eerste proeve van een Rumphius-Bibliographie. (Rumphius-Gedenkboek, uitgegeven door het Koloniaal Museum. Haarlem, 15 Juni 1902. p. 165-220). p. 206, noot 2.

$\Rightarrow$ "Papageno", i896. De Indische Plinius. I-VI. (Java-Bode, Februari 1896. Nos. $30,3.3,36,38,4 \mathrm{r}$ en 44 ). 
gelegenheid van zijn tweehonderdjarigen sterfdag, door het Koloniaal Museum te Haarlem werd uitgegeven, en dat in vrijwel alle groote bibliotheken van ons land te vinden is. $\mathrm{O}_{\mathrm{P}}$ alle gebied geeft dit monument uitkomst aan hem, die verlangend is, iets meer over dezen grootste onzer zeventiendeeeuwsche Indische natuuronderzoekers te weten. ,Meer dan een uit erts gegoten standbeeld ooit zou vermogen te doen, is dit gedenkboek geroepen, de groote beteekenis van Rumphius' onvolprezen werk aan tijdgenoot en nageslacht in het licht te stellen", heeft een der beoordeelaars van dit werk getuigd. Bovendien heeft Leupe ons in I87 I een prachtig gedokumenteerde biographie gegeven, waarin hij alles, wat omtrent Rumphius in het Archief der voormalige Oost-Indische Compagnie te vinden was, bijeen bracht.

Georg Everhard Rump bracht dus zijn jeugd door in Hanau, waar zijn vader, August Rump de naar het schijnt, aanzienlijke betrekking van ,, bouwmeester" bekleedde. Maar dat leven was niet naar den zin van den jongen woelwater JetriaEN; die wilde meer zien van de wereld, dan het kleine Hanau, en ging op avontuur uit. Daartoe aangezocht door zijn vorst en heer, een graaf Ludwig von Solms-Greifenstein-Braunfels, nam hij dienst bij het Venetiaansche leger; het bleek echter al spoedig, dat de grafelijke voorspiegelingen niet volkomen betrouwbaar waren. en hem in dienst hadden gebracht bij de Nederlandsche WestIndische Compagnie. Het plan was, dat de door graaf Solms aangeworven soldaten over Nederland per scheepsgelegenheid naar Venetië gevoerd zouden worden, waarna dan het schip van koers veranderen zou en hen naar Brazilië zou brengen. Maar dank zij een aanval der Portugeezen werd de "Swarte Raef", het schip, waarop Rumphius en zijn lotgenooten zich op Texel hadden ingescheept, opgebracht naar Portugal en werden ze hier in Portugeeschen krijgsdienst gehouden. Die tijd zou 


\section{G. E. RUMPHIUS.}

een beslissing geven over Rumpurs' geheele verdere leven: hier in Portugal werd zijn aandrang naar avonturen geleid in een richting, waarover hij vroeger nooit gedacht had; hier hoorde hij zooveel verhalen van al de merkwaardigheden, die de Oost opleverde, van den wonderlijk weelderigen plantengroei, van de vreemde, grillige dierenwereld, dat zijn lust om te reizen sterk aangewakkerd, maar tegelijkertijd veredeld werd; hij schijnt toen reeds het plan opgevat te hebben, hiervan zijn studie te gaan maken: „zijnde dit wel het meeste oogmerck, waerom ik mij in India begeven hebbe", schrijft hij jaren later in een zijner brieven. (I 8 juli 1669 aan den Gouverneur van Ambon).

Uit Portugal vertrokken, keert hij omstreeks I 648 of I 649 naar Hanau terug; doch zijn verblijf aldaar zou slechts van korten duur zijn: in het eind van 1652 zien we hem dienst nemen als adelborst bij de Oost-Indische Compagnie, die hem van nu af aan onder haar trouwste en meest nauwgezette dienaren zou tellen. Op tweeden Kerstdag $16_{52}$ met het jacht „Muyden" van Texel vertrokken, kwam hij in Juni I653 veilig in Java's hoofdstad aan, om nog in hetzelfde jaar, vermoedelijk 8 November, vandaar naar zijn toekomstige verblijfplaats, het eiland Ambon, te gaan. Maar de militaire dienst was niet datgene, wat hem bevrediging schonk; hij ,was geleert in allerley slach van wisconsten"; wel werd hij al spoedig bevorderd tot vaandrig, maar tegelijkertijd werden van hem adviezen gevraagd over bouwwerken, zoodat JACOB HustaerdT, die toentertijd Gouverneur van Ambon was, hem in civielen dienst overplaatste, reeds in 1657 benoemde tot onderkoopman, (de rangen bij de O.-I. Compagnie waren assistent, onderkoopman koopman en opperkoopman), om hem in I660 aan de Hooge liegeering voor te dragen voor aanstelling tot koopman. Bij missieve van I7 Februari 1662 voldeden Gouverneur-Generaal 
en Raden aan dit verzoek; aan Rumphics werd een salaris toegekend van zestig gulden 's maands.

Omstreeks dezen tijd schijnt Rumpirus begonnen te zijn aan een systematische bestudeering van Ambon's flora en fauna; den 20 en Augustus 1663 schrijft hij Aen d'ED. Erentveste Achtbare, Wyse, Voorsienige, Seer bescheydene Heeren, d'Ed. Heeren Bewinthebberen van de Oost-Indische Compagnie, residerende ter Camer Amsterdam, een „cleen versoeck”, een .,ootmoedich versoeckschrift", ,alsoo (hij) tot seecker syn voornemen U.A.A. gunstige hulpe ten hoogsten van doen heeft".

Het groote belang van dezen brief is zeker wel voldoende verontschuldiging, indien ik hier eenige gedeelten daaruit laat volgen; wij hebben toch hierin te zien een soort werkprogramma, dat Rumphius voor zichzelf had opgesteld, en dat hij nu aan Heeren Bewinthebberen overlegde. Kenmerkend voor zijn groote bescheidenheid zijn zeker tal van gedeelten uit dezen merkwaardigen brief: "' $T$ is dan aldus, dat ick begonnen heb een werck, daer innen in 't Latyn beschreven werden, sodanige planten, gewassen, gedierten etc., als my in de tyt van myne residentie in Indien te sien voorgecomen syn, ende noch sullen voorcomen. Welcke rechte benoemingen, soo uyt de oude Griecxe, Arabische ende Latynsche, als nieuwe autheuren, van my uytgesocht, met malcanderen vergeleecken ende onderscheyden, haere behoorlycke Figuren (voor soo veel const in my is) nae 't leven afgebeelt; overal bygevoeght haere eygenschappen ende crachten, soowel uyt de oude ende voorgaande scribenten als insonderheyt door eygen ervaringe op 't neerstigst uytgewroght, deels oock selfs ondersocht ende byeengedraegen syn, daerby dan noch verscheydene andere ondersoeckinge Scientiam Physicam et Mathematicam aengaende, verhandelt werden; alles met meerder moeyte, neerstigheyt ende geschicter methode, dan betrouwe tot noch toe geschiet 
(i. E. RUMphius.

is." Dan is hij ,hiertoe allerhande goede ende geprobeerde autheuren benoodight, dewelcke my tot een compas in dese Indiaense wildernisse ende steunsel van de memorie mochten dienen". En hij vervolgt: „Aengesien dan Achtbare Heeren dit myn voornemen een werck is, 't welck wel nu ter tyt noch seringhachtig schynt, ende meest tot myne private oeffeninge streckt, nochtans bedenckende dat weleer uyt cleene beginselen, prysweerdige wercken gevolght syn; oock dese myne lucubrationes noch den eenen of den anderen genereusen geest, tot dienst ende vermaeck souden connen strecken, jae, dat selfs noch veele Europeanen, insonderheyt die onder U. A. A. hooghloffelycke regeeringe hun in dese Oostersche Landen ophouden, uyt myne schriften heden ofte morgen eenige profyt ende dienst staen te trecken, ende dat insonderheyt in 't stuck van preservatie haerer gesontheyt, daer wy in Indien tot noch toe seer om verlegen syn, wegens oncunde der middelen, die ons dickwils voor de voeten liggen". Hij verzoekt dan de „Heeren Bewinthebberen", „,seer instandelyck ende met aller eerbiedigheyt" ervoor te willen zorgen, dat de door Rumphics' vrienden, onder wie Ds. Rulicius in Amsterdam, gekochte boeken en instrumenten werkelijk goed bewaard aan Rumphius afgeleverd worden, en niet ,gelijk (hij) alreede niet zonder schade bevonden hebbe", ,uyt suspicie als oft particuliere coopmanschappen waeren (met welcke beuselingen ick my noyt hebbe vercleenen willen), bedorven overgebracht ende verkeert gelevert werden". En de Heeren Bewindhebbers gaven gehoor aan Rumphius' „cleen versoeck” en de aanbeveling, die JOAN Maetsuyker als Gouverneur-Generaal aan Rumphius' schrijven meegaf. De boeken werden door Bewindhebbers onder hun hooge bescherming genomen, ,, mits dat alvorens op het packhuys sullen worden gevisiteert." Men kon toch nooit weten, wat er in die pakken voor Rumphics aan smokkelwaar zat! 
Zoo verloopen eenige jaren, door Rumprits doorgebracht in dienst der Compagnie, zijn vrijen tijd bestedend aan zijn liefste werk, aan het beschrijven en bestudeeren van Ambon's flora en fauna, van de grondvoortbrengselen, van zijn historie, een werk, eerst door de Compagnie oogluikend toegelaten, later, door invloed vooral van MaETsurker, van hoogerhand ondersteund. Hem werd de belofte gegeven, dat hij niet verplaatst zou worden, en dat hem, ,sooveel leedigen tyt gegundt" zou worden, ,als sonder verachtinge van 's Comp. dienst geschieden kon." Want vóór alles bleef Rumphius dienaar der Compagnie.

Toch was Rumphits niet meer met hart en ziel op Ambon. Hij wilde zoo graag vrij zijn, zich geheel kunnen geven aan „syne curieuse studiën”; altoos was hem het ambt van koopman en opperhoofd van Hitoe een ,,masque”, een noodzakelijk kwaad, noodzakelijk omdat hij nu eenmaal voor zich en de zijnen het levensonderhoud moest verdienen. Steeds verlangde hij er naar, eens van alle administratieve en officiëele beslommeringen verlost te worden, om dan zijn geschriften te kunnen voltooien, en voor verdere verzorging hiervan naar Batavia te kunnen vertrekken. En werkelijk scheen hij dit, zijn ideaal, te zullen bereiken. In het begin van 1669 kwam van Batavia de toestemming: hij kreeg verlof, zijn tegenwoordige betrekking neer te leggen, en naar Batavia te komen. Door verschillende omstandigheden, o. a. de afwezigheid van een betrouwbaar schip om Rumphius met zijn familie te vervoeren, en het over-en-weerschrijven, dat hieromtrent tusschen Rumphics en den Gouverneur van Ambon plaats had, werd zijn vertrek vertraagd en steeds weer uitgesteld. En van dit uitstel kwam een geheel onvrijwillig, door het noodlot gedwongen, afstel.

Want het scheen, alsof het geluk en de voorspoed, die RuMpHus tot nog toe steeds als trouwe makkers gevolgd waren, 
G. E. RUMPHIUS.

zich nu van hem afkeerden, en hem overlieten aan de willekeur van het noodlot. In het begin van 1670 trof hem een ramp, zoo groot en zoo diep-tragisch voor den natuuronderzoeker, voor hem, die van natuur-aanschouwen zijn levensgeluk maakte, als geen andere: door te lange inspanning in het tropisch Klimaat had Rumpurts te veel van zijn oogen gevergd: hij werd blind. Wel heel lakoniek waren, zooals LEupe in zijn biographie van onzen geleerde opmerkt ${ }^{\mathrm{I}}$ ), de woorden, die de Gouverneur van Ambon, ЈАСов Cops, meende te moeten gebruiken, toen hij deze zoo in-droevige gebeurtenis aan de Hooge Regeering te Batavia meldde: ,Den coopman Rumphus is nu sedert eenige weken blind geworden." Is er voor een man als Rumphics, vol werkkracht en werklust, een ernstiger teleurstelling en tegenslag denkbaar, dan het verlies zijner oogen, een verlies, dat hem, die alles zelf wilde zien en niet op het gezag van anderen şeloofde, dwong in het vervolg ,,met geleende oogen en handen" zijn werk te doen? En verdient deze man, die, ondanks het diep-tragische lot, dat zijn deel was geworden, met ijzeren wil het werk, dat hij zich als levenstaak had gesteld, voortzette, niet ten volle onze sympathie en eerbied?

Gouverneur Cors achtte echter onzen geleerde niet meer den man om een zoo gewichtig ambt als "Hoofd van Hitoe" te blijven bekleeden; den 20 en Mei i670 deelde hij aan Rumpurus mede, dat hij vervangen zou worden en uitgenoodigd werd, zich met de zijnen naar het Kasteel Victoria op te maken, teneinde daar de nadere beslissing van Gouverneur-Generaal MAetsuykeR omtrent zijn toekomst af te wachten. En deze beslissing viel

I) P. A. Leupe, is7i. Georgius Everardus Runiphius. Ambonsch Natuurkundige der zeventiende eeuw. (Verhandelingen Kon. Akad. v. Wetensch.

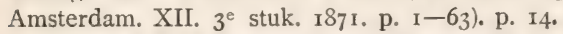

Zie ook J. E. HeEres, igo2. Rumphius' levensloop naar de mededeelingen van P. A. LEUPE. (Rumphius-Gedenkboek. I902. p. I-I6). 
voor Rumpints veel gunstiger uit dan hij waarschijnlijk na de minder heusche bejegening van den kant van Cors wel had gehoopt. MaEtsurker was van meening, dat Gouverneur Cor's wat heel hard jegens den ongelukkigen man was geweest, en dat de belangen der Compagnie wel vereenigbaar waren met andere maatregelen. Teekenend voor MAETstrkers medesevoel met het lot van Rusphits, waren wel deze beschikkingen: „, $\mathrm{OP}$ (het request) van den Coopman Ruviphius... is seresolveert en besloten, (zijn) gagie vooreerst noch tot nader ordre sal blijven voortloopen, alsoo noch niet buyten hope van grenesinge schynt te wesen; te meer syne langduyrige, goede en onopspraeckelyke diensten en dat het oock misschien noch op Hitoe met syn persoon wel wat had mogen aangesien worden: sonder nochtans boven de gagie hem iets anders wegen de Comp. goet te doen, gelyck hier een gebruyck is met personen die geen dienst en doen. Maer is evenwel in opsien van sijn persoon verstaen, dat in Rade des Gouverneurs, oock van Justitie als andere Comp. vergaderingen. daerinne voor desen plach te verschynen, oock nu (vermogens zynde) sal hebben te verschynen besonders oock overal syn oude sitplaets en rang, sonder vercleyninge in dien deele". Spreekt niet hieruit zoowel MAETsuykers streven, om den blinde zoo weinig mogelijk zijn verlies te laten gevoelen, als ook zijn juiste meening, dat Rumphic's scherp verstand en helder inzicht in belangrijke aangelegenheden door het verlies zijner oogen geen schade had geleden: En de Compagnie kon dergelijke ,langduyrige, goede en onopspraeckelyke diensten" van haar ambtenaren uitstekend gebruiken.

Rumprius bleef dus op Ambon, de belangen der Compagnic behartigend en tegelijk zich aan zijn lievelingsstudiën wijdend. Jegens de regeering maakte hij zich verdienstelijk door adviezen, zoowel schriftelijk als mondeling, over fortificatie-werken, over landbouw-toestanden, enz, terwijl de van hem gevergde werk- 
zaamheden niet zoo drukkend waren, of ze lieten hem nog voldoenden tijd om zijn werken te voltooien. Maar ook na zijn blind-worden liet het noodlot niet van hem af: vier jaar later, den 17 en Februari 1674 werden Rumpuic's' vrouw en jongste dochter slachtoffers van de hevige aardbeving, die toen Ambon teisterde. „Erbermelyck was het dien man by deze zyne lycken te zien zitten, alsmede aen te hooren zyne weeklacht, beyde op dit toeval ende zyne blindheid gepast". Toch was een zoo ernstige ramp niet bij machte een werk-zoekenden geest als RumpHits te breken; in het werk vond hij zijn troost; wel schijnt hij gedurende eenige jaren mismoedig en neerslachtig en alsof hij alle lust tot werken verloren had; maar langzamerhand komt hij ook dezen slag te boven en herstelt hij zich met een veerkracht, die bewondering afdwingt.

Het is, alsof het noodlot nu tevreden is met de offers, door RumpHits gebracht; verdere beproevingen blijven hem, wat zijn persoonlijk leven betreft, gespaard, al zullen wij straks zien, dat ook zijn wetenschappelijk werk hem meer dan eens lasten op de schouders gelegd heeft die voor menig ander te zwaar gebleken zouden zijn. Nog dertig jaar lang heeft Rumphius, hoewel lichamelijk blind, de Compagnie met raad terzijde gestaan; tot den 8en Juni I 700 bijv., bleef hij voorzitter van het "Collegie des kleynen Gerigts- en Huwelyckszaecken”, maar werd op dien datum, na zijn herhaald aandringen, als zoodanig ontslagen, daar hij, ,door syne accresserende ouderdom veele debiliteyten onderhavig" was en "door syne indispositie veel maelen dese vergadering niet conde bywonen". De Compagnie liet een zoo verdienstelijk ambtenaar niet gauw los. Dat Rumphits zelf aandrong op vermindering van zijn werkzaamheden, wijst er wel op, hoezeer zijn krachten in dien tijd afnamen; hij, wien geen werk ooit te zwaar gevallen was, voelde dat hij niet meer kon volbrengen, wat zijn positie in de 
Compagnie van hem eischte; hij wilde probeeren het wetenschappelijk werk af te maken, voor het einde daar was, en die voldoening is hem geschonken.

Het einde kwam, den 15 den Juni 1702.

Zoo was het leven van den Compagnies-ambtenaar G. E. Rumphius.

Maar dit, zijn ambtenaarsschap, was hem een "masque"; in den grond van zijn wezen was hij geheel dienaar der Wetenschap. Wel behoorde hij tot de meest nauwgezette en verdienstelijkste ambtenaren, wel heeft hij altijd de hem opgelegde officieele taken met de grootste zorg volbracht, maar toch was zijn bureau niet de plaats, waar hij zijn talenten het meest vruchtbaar kon maken; hij voelde zich pas thuis in de natuur en in zijn studeerkamer. Veelzijdig als geen ander was zijn wetenschappelijke aanleg; alles, wat de natuur hem bood, trok zijn aandacht; maar ook de geschiedenis van het land, waarheen het lot hem gevoerd had en de aardrijkskundige gesteldheid, boezemden hem belang in; zijn mooie "Ambonsche Land-Beschrijving" en "Ambonsche Historie" zijn hiervan de meest welsprekende getuigen.

Op natuurwetenschappelijk gebied heeft Rumprirs een drietal groote werken geschreven: een Amboinsch Kruidboek, een Amboinsche Rariteitkamer en een Amboinsch Dierboek. Als zijn hoofdwerk beschouwt hij wel het Kruidboek, het Herbarium Amboinense, wat voldoende blijkt uit deze zinsnede: „Onder den voorschreven Coopman Rumpuius berusten nog eenige andere schriften, doch van minder belangh, en die hy derhalven Uw HoogEdelh. niet zeer durft aenprysen, zynde de Ambonsche Rariteitkamer, bestaende in drie boecken, ende noch drie andere boecken van Land-, Lugt- en Zeegedierten dezer eylanden....”. (Uit een brief van den Gouverneur van Ambon aan de Hooge Regeering, d.d. 20 Mei 1697). 
Het Kruidboek was het eerste werk, waaraan hij, na aankomst op Amboina (1653) begon; wanneer precies hij met dezen arbeid een aanvang gemaakt heeft, is niet bekend; in ieder geval was hij in $166_{3}$ reeds sedert eenigen tijd ermee bezig (zie blz. 29). Zelf verzamelde hij zijn gegevens; zelf beschreef hij de voorkomende planten in het Latijn met de schitterende nauwkeurigheid van een geniaal liefhebber; zelf teekende hij ze "voor soo veel const in my is", voegt hij er bescheidenlijkbij. Helaas zijn deze oorspronkelijke teekeningen alle volkomen vernietigd, en geen enkele daarvan tot op heden bewaard gebleven. Maar na de groote ramp van zijn blind-worden, in het voorjaar van 1670 , moest hij dit eigen werk opgeven; hij werd nu gedwongen op anderer vaardigheid in het teekenwerk te vertrouwen; andere handen moesten op schrift brengen, wat Rumphius aan belangrijks over de geteekende planten wist, en wat hij er nog van vernam; zijn geest bleef bezielend werken, schiftte belangrijke van onbeteekenende feiten, waarheden van verdichtsels. En daarop volgde nog in 1674 het schrikkelijk ongeval, dat zijn vrouw en zijn jongste dochter trof: zij waren onder de talrijke slachtoffers, die de groote aardbeving van I7 Februari 1674 eischte. Groot was de terneerdrukkencle uitwerking, dien deze droevige ramp op onzen geleerde had; de man, die zich met een bewonderenswaardige blijmoedigheid over het verlies van zijn gezichtsvermogen had weten heen te zetten, was door deze beproeving als versuft; zijn ambtelijke werk bleef hij met de meeste getrouwheid verrichten, maar voor zijn liefhebberijstudie ontbrak hem de lust; eerst langzamerhand zien wij den werkkrachtigen geest overwinnen in den strijd om zijn voortbestaan; de altijd naar geestesinspanning hunkerende man der wetenschap ontwaakt weer uit een verdoovenden slaap.

Zoo wordt dan in 1679 en 1680 aan Rumpinus door de Hooge Regeering achtereenvolgens een "Clerck" en de ,pro- 
visioneele Assistent" DANIEL CRUL toegevoegd, teneinde hem bij zijn arbeid behulpzaam te zijn, terwijl in 1685 een zekere Jв. HogEboon teekeningen voor hem maakt. En ook Rumprits' zoon Pactis Augustus staat hem van nu af ter zijde, tenminste vanaf 1686 , in welk jaar hij, die ook Compagnies-ambtenaar geworden was, als assistent van Batavia overgeplaatst werd naar Ambon.

En zoo was door Rumphius, met de hulp van anderen, bijeengebracht een schat van wetenswaardigheden omtrent Ambon's flora en ook omtrent enkele planten uit andere deelen van ons aan weelderigen plantengroei zoo rijke Insulinde; en kon de Gouverneur DIRCK dE HAEs ervan schrijven: ,nu is "tzelfde zoo goet als ten eynde gebragt, en waren oock alreeds voor zevenhonderd ende 20 capittelen, waeruyt de twaelf boecken des geheelen werckx bestaen, de helft van de nodige figuren zoo door hem als andere teyckenaers vervaerdigt", toen den in zijn persoonlyke leven reeds zoo veelbeproefde man nog meer leed trof, maar nu in zijn wetenschappelijk werk. Door een zwaren brand, die op den I Iden Januari I68 7 de geheele Hollandsche wijk van Ambon vernietigde, werden ook Rumpinu's' boeken, verzamelingen en handschriften voor een groot deel opgeëischt: wel werd het ,principael werck ter naeuwer noot gesalveert", maar alle teekeningen, en dus ook alle voor 1670 door Rumphics zelf vervaardigde, werden een prooi van dit allesverterend vuur.

Ook dezen slag kwam de krachtige persoonlijkheid van Rcupirus te boven. Op zijn verzoek deelde de Gouverneur aan de Hooge Regeering mede dat: ,indien UEd. Achtb. meening nog is, dat hetzelfde werck tot volkomentheyt gebracht werde, zoo zal aenstaende jaer een teyckenaer herwaerts dienen gesonden te worden, dewelcke nevens desselfs soon Augustu's Runphus omtrent een ander halff oft twee jaren die schade zouden vergoeden connen; alzoo geoordeelt wert, dat gemelte werck zonder figuren weynig nut ende aensien zoude hebben, 
G. E. RUMPHIUS.

al zoude men alleen de voornaemste daervan opmaecken". Als antwoord hierop toonde de Hooge Regeering - de ruimdenkende Canphuys was toen Gouverneur-Generaal - weer haar warme belangstelling in Rumpurus' wetenschappelijken arbeid, door hem een "teyckenaer" te zenden, een scheepsjongen Philips van Eyck, die dan onder leiding van Pallu's Augustus Rumphus zich in teekenen kon bekwamen ${ }^{2}$ ).

Door aller medewerking wordt nu de schade zoo spoedig mogelijk hersteld; in het laatst van 1690 zijn de eerste zes boeken gereed, zoodat ze naar Batavia verzonden kunnen worden, om vandaar naar patria te worden verstuurd. Midden I692 vinden wij dan dit handschrift op reis naar Nederland aan boord van het schip „Waterland", dat echter zijn bestemming nooit bereiken zou. Den I 2 den September van dat jaar werd de ,Waterland", het admiraalsschip van de retourvloot, onder bevel van den Commandeur Willexr Kenp, do or de Franschen in den grond geboord, ,met volck ende al seer erbarmelyck is gesoncken, niet boven de twaelff man in de schuyt daervan afgekomen synde".

„Maar noch de zon, die den schrijver door haar stralen verblindde, noch het vuur, dat zijn geschriften verteerde, noch het water, dat ze in zijn golven begroef, waren in staat, dit zeer kostbare werk aan de letterkundige wereld te ontrooven", schrijft Henschel in zijn prachtig-uitgewerkte studie: „Vita G. E. Rumphii" ${ }^{2}$ ). En inderdaad, het was of de zorgzame beschermer van onzen geleerde, de oud-Gouverneur-Generaal Camphurs een dergelijk lot voorzien had; hem danken wij zijn

ェ) Zie over de handschriften van het Kruidboek en hun lotgevallen: J. P. Lotsy, 1902. Over de in Nederland aanwezige botanische handschriften van Rumphius. (Rumphius-Gedenkboek. 1902. p. 46-58).

2) A. G. E. Th. Henschel, i833. Vita G. E. Rumphit, Plinii Indici . . . . Vratislaviae (Breslau), 1833. p. 42. 
voorzorg, om van deze zes boeken, alvorens ze aan de willekeur van een verre reis toetevertrouwen, een afschrift te laten maken. Hoe nu ook de beweegredenen van CAuphuys voor dit copieeren waren, al was misschien zijn , voorliefde voor het copieeren van andermans geschriften al te bedenkelijk" ") -; we mogen toch niet vergeten, dat door dit afschrift een onherstelbaar verlies voorkomen is. $\mathrm{Nu}$ was het mogelijk de door Camphuys te Batavia achtergehouden copie opnieuw te laten afschrijven en de eerste copie naar Europa te zenden. Dit geschiedde dan ook en wel den 8sten Februari i696 met het schip ,Sir Janslandt”. Tegelijkertijd werden de boeken 7,8 en 9, die inmiddels door Rumphius van Amboina naar Batavia gezonden waren, na gecopieerd te zijn, naar het vaderland overgemaakt. En spoedig daarop volgden de laatste drie boeken, die ook eerst te Batavia zorgvuldig afgeschreven werden. De zorg te Batavia was inmiddels van CAuphuys, die den I8den Juli 1695 overleed, overgenomen door den heer IsAaC DE St. Martin, Raad van Indië, en na diens overlijden op i 4 April i6g6 door Cornelis Chasteleyn. En ten slotte werd den $24^{\text {sten }}$ September i 70 or nog een Auctuarium naar Batavia gezonden met verzoek om dit toch vooral te doen copieeren, daar ,van alle figuren, die daerinne leggen, seer weynig of geen minuten off affteeckeningen daervan hier gebleven syn". Met de drie laatstgezonden deelen waren ook de beide helpers van Rumphics, de "provisionele adsistent" Johan Philip Sipman en de , teyckenaer" Philip van Eyck, naar Europa vertrokken. Voor zijn vertrek had PHILIP van Eyck een soldaat, Pieter de Rurter, teekenen geleerd, zoodat deze hem bij zijn vertrek, September I 696 kon vervangen.

De Bewindhebbers in Amsterdam bewonderden het werk

Rouffaer en Muller, 1902. p. 185 , noot 6. 
G. E. RUMPHIUS.

van Rumpirus zeer; ze vonden het van ,,eene bysondere curieusheyt, en waerinne verscheyde nutte en aenmerckenswaerdige saecken souden kunnen vervat staen". Volgens de meening van Heeren Zeventienen is het ,waerlyck een werck, dat wy bevinden met veel kennisse, studie ende applicatie samengestelt ende uytgewrocht te syn; behelsende onder andere notabele stucken, verscheyde die niet alleen van speculatie en curieusheyt syn, maer die te gelyck een bysondere nuttigheyt, en light in veele, ende bysonder ten reguarde van de Moluxe speceryen, de culture ende 't havenen van dien enz., komen te geven"... Zulk een "pryselycke moeyte" willen bewindhebbers niet ,onbeloont laeten", om welke reden ze ,goedgevonden hebben, teneinde voornoemde Rumphits by provisie eenigermate dieswegen te remunereren, desselfs soon P. A. RumrHIUs, Ondercoopman ende jongst Hooft op Larique, te avanceeren ende aan te stellen tot Coopman, met een tractement van $f 60$ ter maent".

Hoe mooi de Heeren Zeventienen het werk ook vonden, toch achtten ze het niet juist geschikt om gedrukt en uitgegeven te worden. Een desbetreffend verzoek van eenige liefhebbers en boekdrukkers wordt dan ook den igden Februari i 700 afgewezen met de woorden: ,is nae deliberatie verstaen het drucken van voorsz. boecken als ondienstigh in dese in geene opsighten te excuseren". En toen de Heeren twee jaar later, den ${ }_{15}$ den September I7O2, van meening veranderd waren, en ,goedvonden de Kruytboecken van den Oudt-Coopman G. E. Rumphits in de jaren... herwaerts gesonden, soo sigh eenige liefhebbers tot het drucken van dien, het sy voor 't geheel, off wel ten deele quam op te doen, deselve dat toe te staen, dogh alles buyten kosten van de Comp."; toen meldde zich geen lief hebber aan.

Jaren verloopen, alvorens in de resolutiën van Heeren 



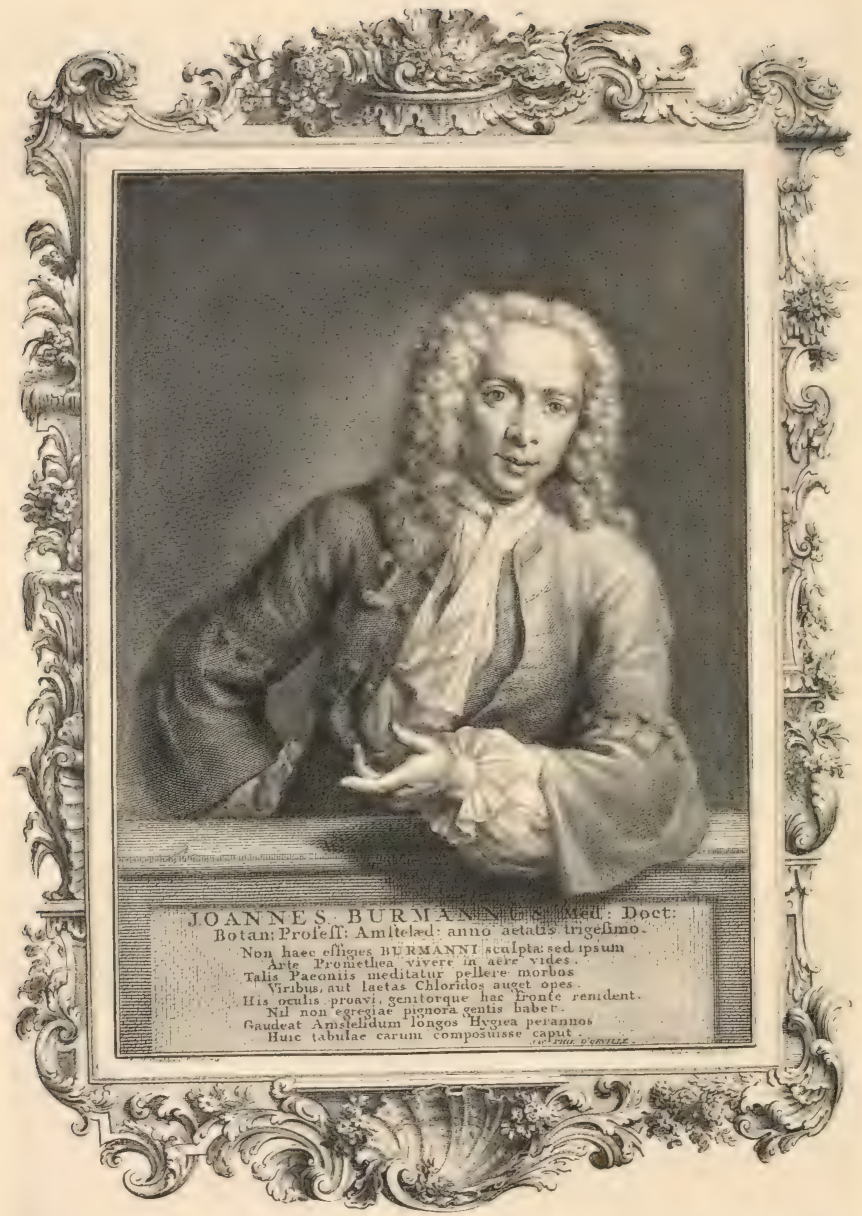


Zeventienen weer over het Herbarium Amboinense gesproken wordt: pas in 1736 blijkt de Amsterdamsche hoogleeraar Johannes Burmannus het voornemen te hebben het Kruidboek uit te geven; dit wordt hem toegestaan: „met consent om deselve boecken, buyten kosten van de Comp. vervolgens in druk te mogen uytgeven, zonder eghter daerin te brengen eenige passagien die tot nadeel van de Compagnie zouden konnen strecken". Inderdaad, Prof. Hartisg had wel gelijk, toen hij in zijn Rumpurs-biografie schreef $^{\mathrm{x}}$ ): „,alles, wat de politieke en commercieele belangen dier koloniën en de daarvan voor het moederland te trekken voordeelen betrof, werd achter een driedubbel slot bewaard, en het zoude aan de daar aangestelde ambtenaren der Compagnie als verraad zijn toegerekend, daaromtrent zonder uitdrukkelijk verlof iets wereldkundig te maken".

Oorspronkelijk had Rumphits zijn werk in het Latijn geschreven (zie zyn brief aan Heeren Bewinthebberen d.d. 20 Augustus $166_{3}$, blz. 29: een werck, daerinnen int Latyn beschreven), maar later in het Hollandsch vertaald. Burian achtte het nuttig, dit weer in het Latijn over te brengen en Hollandsche en Latijnsche tekst samen uit te geven. Zoo verscheen ,Het Amboinsche Kruidboek. Dat is beschrijving van de meest bekende Boomen, Heesters, Kruiden, Land- en Water-Planten, die men in Amboina en de omleggende eylanden vind. $\mathrm{Na}$ haare gedaante, verscheide benamingen, aanqueking, en gebruik: mitsgaders van eenige insecten en gediertens, Voor 't meeste deel met de Figuren, daar toe behoorende, Allen met veel moeite en vleit in veele jaaren vergaadert, en beschreven in twaalf boeken door Georgius Everhardes Rliphius" .... in in zes folio-

I) P. Harting, 1885. George Everhard Rumpius geschetst door ..... (Album der Natuur. 1885. p. I-I5). p. Ir. 
G. E. RUMPHiUS.

deelen in de jaren $174 \mathrm{I}^{-1} \mathrm{I}^{\mathrm{I}} \mathrm{O}^{\mathrm{I}}$ ); als zevende deel verscheen nog in 1755 het Auctuarium, eveneens door de zorgen van BURMAN ${ }^{2}$ ).

De plantensystematiek was in den tijd, waarin Rumphius zijn Herbarium Amboinense bewerkte, nog een wikkelkindje; het stelsel van indeeling, dat door Van Reede (zie blz. 21), werd gebruikt, was ook het systeem van Rumphius; een korte opgave van de titels der twaalf boeken zal voldoende zijn om deze wijze van orde-scheppen in een overweldigende veelvuldigheid van vormen te kenmerken:

Boek I: Begrypende alderley Boomen, die eetbare Vrugten dragen, en door Menschen gehavend worden;

Boek II : Behelzende de speceryagtige Boomen: dat zyn die gene, die eenige speceryagtige vrugten, schorssen, ofte welriekend hout dragen;

Boek III : Behelzende die Boomen, dewelke eenig Hers, aanzienlyke Bloemen, of schadelyke Melk van haar geven;

Boek IV: Handelende van de wilde Boomen, waar van men Timmerhout heeft;

Boek V: Handelende van de overige wilde bomen onder malkanderen ;

ז) Uitgevers van dit werk waren: te Amsterdam Françors Changuion en Hermanus Uytwerf, te 's Hage Pieter Gosse, Jan Neauluie, Adriaan Moetjens en Antony van Dole; voor de deelen I-IV bovendien te Amsterdam Jan Catuffe en te Utrecht Steven Neaulme. Daarna kwam in 1750 een nieuwe titeluitgave van de pers, nu bij Mernard Uytwerf, te Amsterdam, die door aankoop eigenaar van het recht tot uitgaaf geworden was.

2) Dit Auctuarium werd uitgegeven bij Meinard Uytwerf en de Wed. S. Schouten EN Zoon. Verdere bibliographische bijzonderheden omtrent deze uitgaven zijn te vinden in de reeds genoemde ,Eerste proeve van een RumphiusBibliographie", door G. P. Rouffaer en IV. C. Muller. (Rumphius-Gedenkboek. 1902. p. 165-220), een arbeid, zóó mooi van opzet en uitwerking, en zoo vol belangwekkende mededeelingen, dat de titel: „Eerste proeve”, wel wat heel bescheiden is. 
Boek VI: Handelende van de Heesters, zo tamme als wilde; Boek VII: Behelzende de Bosch-touwen en kruypende Heesteren ;

Boek VIII : Behelzende de Hofkruyden, zo wel die tot de kost, als Medicyn, en vermaak dienen;

Boek IX: Van Winden en omslingerende kruipende Kruiden ;

Boek X: Handelende van de Wilde Kruiden door Malkander;

Boek XI: Handelende van de overige of resteerende wilde Kruiden ;

Boek XII : Handelende van de Zeeboompjes, en steenagtige Zeegewassen, die na een Plant gelijken.

Weliswaar ontbeert een dergelijke indeeling allen wetenschappelijken grondslag; maar toch heeft ze een eigenaardige bekoring: "die Boomen, dewelke eenig Hers, aanzienelyke Bloemen, of schadelyke Melk van haar geven”, ,Bosch-touwen” voor lianen, zijn het geen bewijzen voor den onbevangen blik, waarmee Rumphius in zijn Ambonsche natuur rond zich zag? In al die hoofdstukken geeft Rusphuss niet alleen uiterlijke beschrijvingen van de besproken planten, beschrijvingen, die meestal tot in kleine bijzonderheden juist zijn, een enkele maal wel eens, vooral waar het heel kleine bloemen betreft, niet volkomen nauwkeurig; maar verder een aantal aanteekeningen, volkomen natuurgetrouw en zuiver, omtrent de produkten, die door de planten geleverd worden, de plaats, waar ze gevonden of gekweekt worden, den tijd, waarin ze bloeien, de wijze van cultuur, het gebruik, dat ervan gemaakt wordt, en wel zoowel medisch als technisch, en andere dergelijke bijzonderheden. Bovendien geeft hij zooveel mogelijk van de planten, behalve Hollandsche, Maleische en Latijnsche namen, nog die in de talen van Amboina, Ternate, Banda, Makassar, Java, soms Arabië en China, Portugal en Hindoestan. „En daarbij had 
G. E. RUMPIHUS.

hij niet", zegt Henschel in zijn meergenoemde biographie ${ }^{x}$ ), ,ZOoals VAN REEDE te beschikken over raadgevingen en kennis van geleerde Europeanen en Brahmanen, maar hij moest zijn wetenschap zelf uit het leven putten en door eigen ervaring ,,in dese Indiaense wildernisse" met grooten ijver verkrijgen". Ook al wat op de zeden en gewoonten der bevolking betrekking had, welk bijgeloof bijv. er omtrent een bepaalde plant heerschte, deelde hij mede, steeds verdichtsels van waarheid scheidend. Dan vergeleek hij zijn resultaten met de medcdeelingen van Plinics, Aristoteles, zijn onmiddellijke voorgangers Bontius, Garcia AB ORTA e.a., daarbij steeds van een groote scherpzinnigheid en een schitterende belezenheid blijk gevend.

Zuiver zijn zijn waarnemingen; is hij niet volkomen zeker van de juistheid zijner mededeelingen, dan vermeldt hij dit uitdrukkelijk; waar hij bijv. voor het in zijn tijd raadselachtige voorkomen der ,coco de mer", de vrucht der Seychellen-palm, die in Indië soms aan de kust aangespoeld aangetroffen wordt, een oplossing zoekt, daar geeft hij er een, maar met aarzeling; hij voelt heel goed het gebrek aan feitenmateriaal en hecht zelf aan zijn vermoeden, dat genoemde vruchten zouden behooren tot een onder zee groeiende plant, weinig waarde. Daartegenover heeft hij bij tal van andere onderwerpen de gelegenheid te wijzen op het eigenaardige karakter der tropische flora, op de aanwezigheid van biologische bijzonderheden in het plantenleven, waar men in Noordelijke streken niet van droomt; zoo zijn "Bosch-touwen”; de bekende bekerplanten, wier bekers niet als vruchten der planten, maar ,slegts voor een uitwas van 't blad" gehouden moeten worden; het merkwaardig en nog voor onzen tijd moeilijk te verklaren verschijnsel van cauli-

s) A. G. E. Th Henschel, I833. p. 50. 
florie, d.w.z. het te voorschijn komen van vruchten onmiddellijk uit den stam, bijv. bij Cacao, en tal van andere, belangrijke biologische waarnemingen. Van de bekende stamwoekerplant Cassytha bijv. geeft hij deze schildering: ,de voeten van de vis Polypus gelykende, namentlyck korte vingers van witagtige wratten gemaekt, waarmede sij haer aen de voorn. takken vast setten, en haer voordeel uyt een vreemt liggaem trecken, op de selfde manier als het Viscum - onze Maretakken doet, dierhalve moet men dese pootjens, voor syne wortels houden, die op den geheelen struyck soo verspreydt syn, dat men niet raden kan welcke de eerste hoofdwortel sij, daer hij syn eerste begin van genomen heeft".

Ook over de verspreiding van planten heeft Rumpric's belangrijke waarnemingen gedaan; van tal van Amerikaansche planten, die vooral door den handel van Spanjaarden en Portugeezen in onze koloniën waren terecht gekomen, vermeldt hij de vermoedelijke herkomst; bij de verspreiding van Carica Papaya bijv., waarvan trouwens reeds door JAN HLyGeN VAN Linschotex gewag gemaakt wordt, denkt RumpHiss aan de mogelijke medewerking van vogels.

Zoo is met recht het Ambonsch Kruidboek een standaardwerk van blijvende waarde, een voortdurende bron van studie, ook voor den botanicus der twintigste eeuw. Weliswaar is de nomenclatuur van tegenwoordig een geheel andere, dan de door Ruxphuts gebruikte: de officiëel aangenomen prioriteitsdatum (1753, Linnaeus' Species Plantarum) immers doet het Herbarium Amboinense daar buiten vallen; de door OtTo Kuxtze aangewende poging om het jaar 1737 als aanvang van prioriteit te doen beschouwen, zoodat RLishius' werk er ook in betrokken werd, is mislukt. Dientengevolge is het niet altijd gemakkelijk een bepaalde plant in het Herbarium Amboinense terug te vinden; belangrijke hulpmiddelen zijn wel hierbij de „Clavis 
Ilerbarii Amboinensis" van HeNschel ${ }^{\text {) }}$ en vooral de "Neuer Schlüssel" van Hassiakl $\left.{ }^{2}\right)$. Dit laatste werk heeft voor de bestudeering van Ruminus' Kruidboek zeer groote waarde, temeer daar er in opgenomen zijn de resultaten van een botanische reis door de Molukken, door den Buitenzorgschen Hortulanus Teysmany verricht (1853-1860), door wien een aantal planten, ten tijde van Henschel nog onbekend, weergevonden zijn. Behalve een uitvoerige bespreking van alle twaalf boeken van het Kruidboek, geeft HAsskarl een drietal alphabetische inhouden: een voor de Latijnsche namen van Rumpusus, een voor inlandsche namen, en een voor de wetenschappelijk-systematische namen, die in I 866 van kracht waren.

Uit het totnogtoe medegedeelde blijkt dus ten duidelijkste, hoe groote verdiensten Rumphus als botanicus had; hoe hij niet alleen door zijn floristische beschrijvingen de kennis van den plantengroei op Ambon en andere eilanden van onzen Indischen Archipel heeft gegrondvest, maar hoe hij ook in zijn Kruidboek een groot aantal wetenswaardigheden over het leven der planten heeft bijeengebracht, zoodoende een begin makend met de biologische bestudeering der tropische flora.

Veel minder gemakkelijk is het de waarde van Rumpurus' werk op zoölogisch gebied in zijn vollen omvang te overzien: wel geeft de Amboinsche Rariteitkamer ons een inzicht in zijn wijze van werken, en een kleine afschaduwing van zijn vele belangwekkende vondsten, maar toch zijn er gronden om aan te nemen, dat deze Rariteitkamer eigenlijk meer een werk, bestemd voor liefhebbers van natuurhistorische wonderprodukten, die er in dien tijd in overvloed waren, zou zijn.

Voor een juiste beoordeeling van Rumphuts als zoöloog is

I) A. G. E. Th. Henschel, 1833. p. 139-202.

2) J. K. Hasskarl, i866. Neuer Schlüssel zu Rumph's Herbarium Amboinense. (Abhandl. Naturf. Ges. Halle. IV. I866. p. 143-389). 
dit echter geenszins voldoende, waar wij weten, dat hij behalve deze Rariteitkamer nog een boek: „Van Land-, Lugt- ende Zeegedierten deser eylanden", bewerkt heeft. Of dit laatste werk nog door hem afgemaakt is, is onbekend; in 1697 nog schreef de regeering te Amboina aan de Hooge Regeering over deze beide werken: „om welcke te perfectioneeren hij zelffs weynigh moed heeft wegens zyn ouderdom ende aengro€yende swackheden". Maar toch wil hij gaarne aan het werk blijven, „om de geesten wat werck te geven, zonder het welck hy anders sorgt in melancholy zyne dagen te sullen moeten eyndigen". Helaas is echter van dit „Amboinsch Dierboek" niets bekend: het handschrift schijnt verdwenen te zijn; uitgegeven is het nooit, zoodat wij absoluut niet in staat zijn, de waarde van dit Dierboek te schatten. Wat er ooit van gedrukt is, en dit is misschien meer dan vermoed wordt, staat niet op naam van Rumphics, maar is opgenomen in de "Verhandeling der dieren van Amboina", van Ds. Valentrx. Immers het is nu wel zekerheid geworden, wat Leupe ${ }^{\mathrm{x}}$ ) en na hem tal van anderen, o. a. WARBtRG ${ }^{2}$ ) als vermoeden geuit hadden, dat nl. Valentyn bij de bewerking van zijn in de jaren $1724-1726$ verschenen "Oud- en Nieuw-Oost-Indiën" een ruim gebruik gemaakt heeft van de aanteekeningen en handschriften van RuMphics, terwijl hij het daarbij niet of maar een enkele keer noodig achtte den naam van zijn ,zwager en boezemvriend" Rumpinus te noemen. Waarschijnlijk heeft Valentijn dan ook in zijn "Verhandelingen der dieren van Amboina" 3) Ruspulus" Dierboek zoodanig ",bewerkt" of overgeschreven, dat Bukmax,

ז) P. A. LEUPE, I87 I. p. $37-38$.

2) O. IVArburf, I897. Die Muskatnuss. Ihre Geschichte, Botanik, Kultur, Handel und Verwerthung, sowie ihre Verfälschungen und Surrogate. Zugleich ein Beitrag zur Kulturgeschichte der Banda-Inseln. Leipzig. IS97. p. 320.

3) Oud- en Nieuw.Oost-Indiën. Deel III. Stuk $r$ en 2. 
(i. E. RUMPHIUS.

die in 1746 het plan opperde, om ook dit Dierboek, waarvan het handschrift, ,zoo ik verstaan heb, van zyn naastbestaande ofte nakomelingen zeer zorgvuldig bewaart" is, dit plan in I 747 reeds voorgoed opgegeven heeft. Dat VALEntyn gebruik gemaakt heeft van RuxpHus waarnemingen is dus zeker, alleen is niet na te gaan, in hoeverre dit geschied is. Kenmerkend voor VALENTYNS „oorspronkelijkheid” zijn wel de voorbeelden die Rouffaer en Muller in hun bibliographie ${ }^{2}$ ) opgeven omtrent de Paradijs-vogels als liefhebbers van Tsjampadahavruchten, waarover RumpHits in zijn Kruidboek Deel I Boek I Fol, I09, schrijft en er bijvoegt: „daarvan kan bij 't Amboinsch Dierboek parte 2, wat nader gezien en gelezen worden", en de „Beschryvinge van den Serpenticida, of Moncus”. Hoe dit echter zij, zeker is, dat Rumphius behalve zijn uit drie boeken bestaande Rariteitkamer, nog drie boeken over Land-, Lugtende Zeegedierte geschreven heeft en voornemens was, deze drie als een Dierboek samen te vatten.

$\mathrm{Nu}$ kennen wij RumpHus' dierkundig werk zeer onvolledig en mogen wij dus over zijn waarde als zoöloog geen oordeel uitspreken, al zou dit oordeel ook naar de gegevens, die wij thans hebben, heel gunstig moeten luiden. Het handschrift van de ,Amboinsche Rariteitkamer, behelzende eene Beschrijvinge van allerhande zoo weeke als harde Schaalvisschen, te weete raare Krabben, Kreeften en diergelijke Zeedieren, alsmede Hoorntjes en Schulpen, die men in d'Amboinsche Zee vindt. Daar beneven zommige Mineraalen, Gesteenten en soorten van Aarde, die in d'Amboinsche en sommige omleggende Eilanden gevonden worden", dit handschrift kwam met bekwame hulp van Sipman en Rumphius junior in 1699 gereed en werd şezonden aan één van Rumphius' beste vrienden, den Delftschen

I) Rouffaer en Muller, 1902. p. 167. 



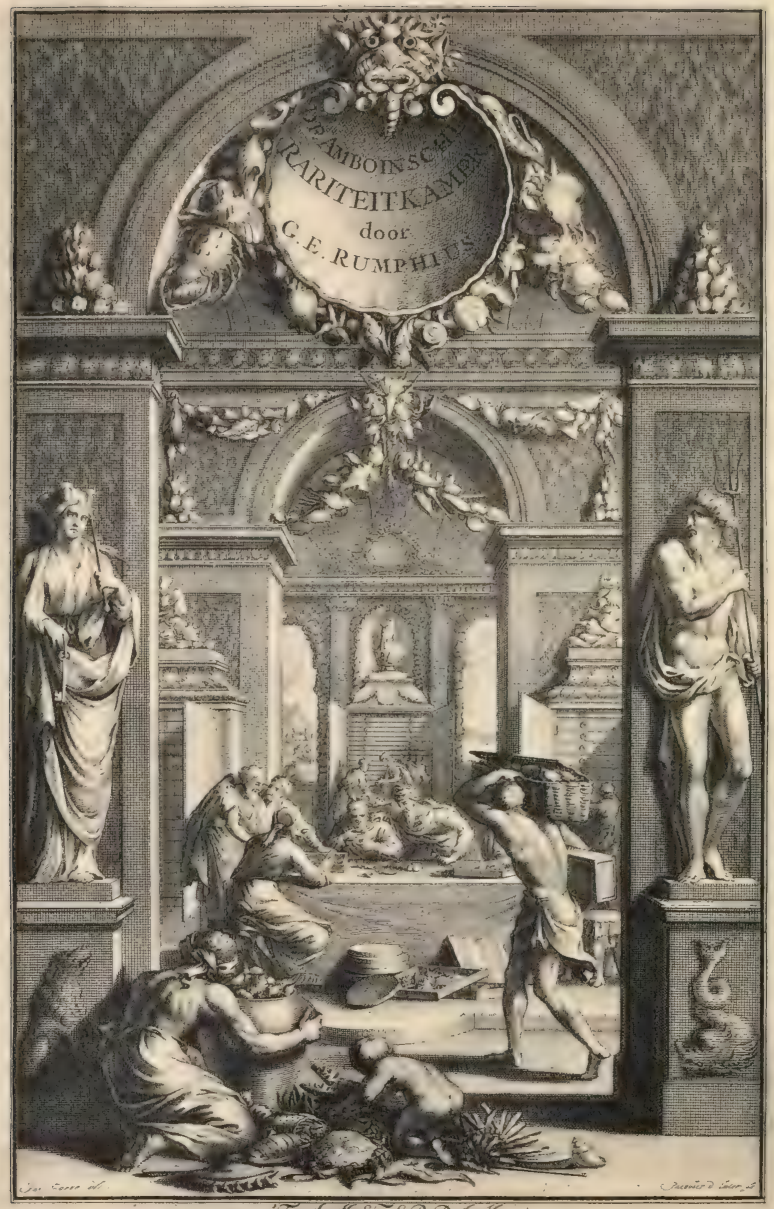

Gedrukt by FRANÇOIS HALMA Boekverkoper. 1705 
burgemeester Dr. D'ACQuet. Na het in r jor ontvangen te hebben, oordeelde D'ACQUET het raadzaam dit werk, dat van zoo groot nut kon zijn voor de talrijke liefhebber-verzamelaars van ",Schulpen en hoorntjes", die ons land toentertijd herbergde. zoo spoedig mogelijk uit te geven. Hij vertrouwde de uitgave toe aan den Amsterdamschen boekhandelaar Françors Halma, bij wien het in I705 verscheen. Halma is zoo verstandig geweest bij de verzorging van het werk de hulp in te roepen van een deskundige: Simon Schijnvoet; hij schrijft hierover in zijn opdracht aan Dr. D'Acquet : „Veele zaaken ook, Ed.Achtb. Heer, waren door den Schryver maar, als men zegt, met den vinger aangeroert, die nootwendig eene nadere uitbreidinge vereischten; gelyk'er ook zulke in 't geheel ontbraken, die er, zonder de schikking en orde van 't werk te schenden, niet aan mogten gemist worden. Hiertoe was tyd, onderzoek en arbeid van nooden; en wy willen voor Uwe Ed.Achtb. niet verbergen, dat wy zonder de hulpe en vlyt van den Heere Simon ScirvVOET, groot kenner en liefhebber dezer Frayigheden, en onzer beide geëerde vriendt, niet waren terecht gekomen; als die, alles in den grond kennende, niet alleen de aftekeningen der af beeldzelen die 'er ontbraken, maar het werk zelf met zyne nauwkeurige waarnemingen, die hetzelve eene byzonderen luister en veel lichts toebrengen, doorgaans verrykt heeft". Op een dergelijke wijze dus als Burman zorgde voor de uitgave van het Kruidboek, was door Schynvoet gezorgd, dat de Rariteitkamer meer volmaakt werd. Immers Rumpuls bezat op zijn ver van alle westersche wetenschap verwijderde woonplaats zoo goed als geen boeken over het onderwerp, dat in zijn Rariteitkamer behandeld werd en de weinige boeken, die hij bezeten had, waren door den grooten brand van 1687 vernietigd. Dus was het handschrift, zooals het uit Indië kwam, niet voor de pers geschikt; het moest hier en daar wat bijgewerkt en aan- 
G. E. RUMPHIUS.

gevuld en verbeterd worden, zoodat het meer in overeenstemming kwam met den stand der wetenschap in het Westen. Het eerste boek der Rariteitkamer, gewijd aan de „Weeke Schaalvisschen", bevat een uitvoerige behandeling van de in de Molukken voorkomende Crustaceeën, waaronder vooral zijn beschrijving van de in vele opzichten zoo belangrijke Molukkenkreeft, Limulus Moluccanus Lam., onze belangstelling verdient; verder geeft hij beschrijvingen en afbeeldingen van een aantal stekelhuidigen: Zeeëgels, Zeesterren, en Slangsterretjes en van nekele Koralen, uit welke groep echter de meeste vertegenwoordigers besproken zijn in het twaalfde boek van zijn Herbarium Amboinense; in het geheel beslaat dit eerste boek der Rariteitkamer 54 bladzijden en 16 platen. Zooals overal in zijn werken geeft Rusiphics ook hier niet een droge beschrijving der in de Molukken voorkomende diersoorten, maar vlecht hij hier en daar bijzonderheden in van groot belang omtrent het leven der dieren, hun aardrijkskundige verspreiding, hun nut voor den inlander e.a. Zoo is bijv. uitermate belangrijk, ook voor ons in den tegenwoordigen tijd nog, wat hij meedeelt over het zoo merkwaardige voorkomen van de „Wawo", Lysidice Oele R. Honst (Rariteitkamer Boek I, Hooftdeel 44, Fol. 5I-54) ${ }^{\text {I }}$. Hetgeen Rumphius ons hier verhaalt over wat hij omtrent de levenswijze van deze, twee eeuwen na zijn tijd nog bijna even raadselachtige, wormsoort waarnam, is een zoo mooi bewijs voor zijn scherpe opmerkingsgave, dat ik er hier even bij wil stilstaan. Rumphus beschrijft deze dieren als: „Wormtjens, schaars een voet lang, in de dikte zommige als zeilgaarn, doch de meeste als getweernde zyde, in klompjes door malkander vermengt, daar in men altyd d'eene grooter, dikker en langer ziet dan de andere, 't welk men voor de Moeder houd. De

×) R. Horst, I902. Over de „Wawo” van Rumphics. (Rumphius-Gedenkboek. Ig02. p. 105-108). 
coleur is veelderley. De meeste zyn donker groen, doch daar onder speelt vuilwit of geel, rood, bruyn en een weinig blauw, ... welk men de Moeder noemt heeft de dikte van het groffste zeilgaren, en zomtyds als een dunne schacht, bleekgeel of witagtig, het hooftje even buiten 't water steekende, daaraan men niets dan twee hoorentjes bekennen kan, gelyk de Slekken hebben, en aan iedere zyde vier duidelyke voetjes, gelyk rupzen".

Maar behalve deze uiterlijke vormbeschrijving doet RıMprucs ons hier een allermerkwaardigst verschijnsel kennen, dat deze wormen vertoonen: ze komen alleen op gezette tijden, en wel eenmaal per jaar, ,na zonsondergang op het water drijven, nabij die stranden, waar groote rotsen in zee staan, die vol scheuren zijn; bij brandende toortsen worden ze dan met uitgespannen doeken of fijne zeven uit het water geschept" :). En de tijd, waarop de dieren aan het strand komen is juist na zonsondergang , alleen den 2 den, $3^{\text {den }}$ en $4^{\text {den }}$ avond na de volle maan" in Februari of Maart, soms drie avonden achtereen, soms, en wel indien het weer zeer heet en droog is, slechts één avond. Dit belangrijke verschijnsel, het regelmatige optreden dezer wormen eenige dagen na volle maan, is nu, twee eeuwen nadat Rumpulus het opgemerkt heeft, nog een onopgelost vraagstuk; wel weten we, dat de vangst van Wawo nog altijd aanleiding is voor de bevolking om feest te vieren; dat ze nog steeds tusschen 6 uur 's avonds en maansopkomst gevangen worden en aan de inlanders een zeer gezochte toespijs opleveren ${ }^{2}$ ); wel is door de onderzoekingen van Dr. Hors'T gebleken, dat de wormen zich ten tijde van hun verschijnin: in geslachtsrijpen toestand bevinden en dus hiermee de jaarlijksche periodiciteit verklaard, maar waarom het dier juist

I) R. Horst, 1902. p. 105 .

2) Max Weber, I899. Bulletin van de Maatschappij tot bevordering van het Natuurkundig Onderzoek der Nederlandsche Koloniën. No, 34. 1). 7. 
(i. E. RUMPHIUS.

eenige dagen na volle maan verschijnt, is tot op heden onbekend.

Het tweede boek der Rariteitkamer beslaat de folio-bladzijden 57-I66 en behandelt uitsluitend Mollusken en wel voornamelijk tot de Gastropoden behoorende soorten. Ook op dit zoo moeilijke gebied toont Rumprius' werk, hoe een onbevangen onderzoeker met scherp waarnemingsvermogen in een oogenschijnlijken chaos orde weet te scheppen. Als het ware op het gevoel af maakt Rumphius sommige geslachten en families, die zoo volkomen juist gegroepeerd zijn, dat hun omgrenzing ook nu nog algemeen geldend is. Zijn nomenclatuur is vaak heel gelukkig gekozen; als voorvoelend de binaire nomenclatuur van Linnaeus heeft ook hij een aantal schepdieren met twee namen aangeduid, steeds een geslachtsnaam en dan een bijvoegelijk naamwoord als soortsnaam. Een belangrijk getal nieuwe soorten werden door hem beschreven; van de 359 soorten, in dit tweede boek besproken, waren er I57 nog niet bekend, hoewel er toch in den loop der zeventiende eeuw reeds een paar speciale conchyliologische werken verschenen waren ${ }^{\mathrm{I}}$ ), Behalve zijn verdiensten op morphologisch gebied, toont hij ook hier weer zijn wetenschappelijken aanleg door de bestudeering van het leven der door hem beschreven dieren; steeds deelt hij mede op wat voor zeebodem de dieren leven, hoe ze zich bewegen of hoe ze aan den bodem bevestigd zijn, dat soms ,haar koleur ook naar den grond geschikt is", d. w. z. dat ze aan de omgeving aangepast zijn, en dergelijke belangwekkende bijzonderheden meer; hij bespreekt steeds het nut, dat deze schelpdieren voor de bevolking opleveren, vermeldt hun voedzaamheid of vergiftige eigenschappen, hun

I) Bijv. MI. Lister, I685-(1693:). Historiae sive synopsis methodicae conchyliorum, quorum omnium picturae ad vivum delineatae exhibentur. 11. IV. Londini. $1685-(1693$ ?). 



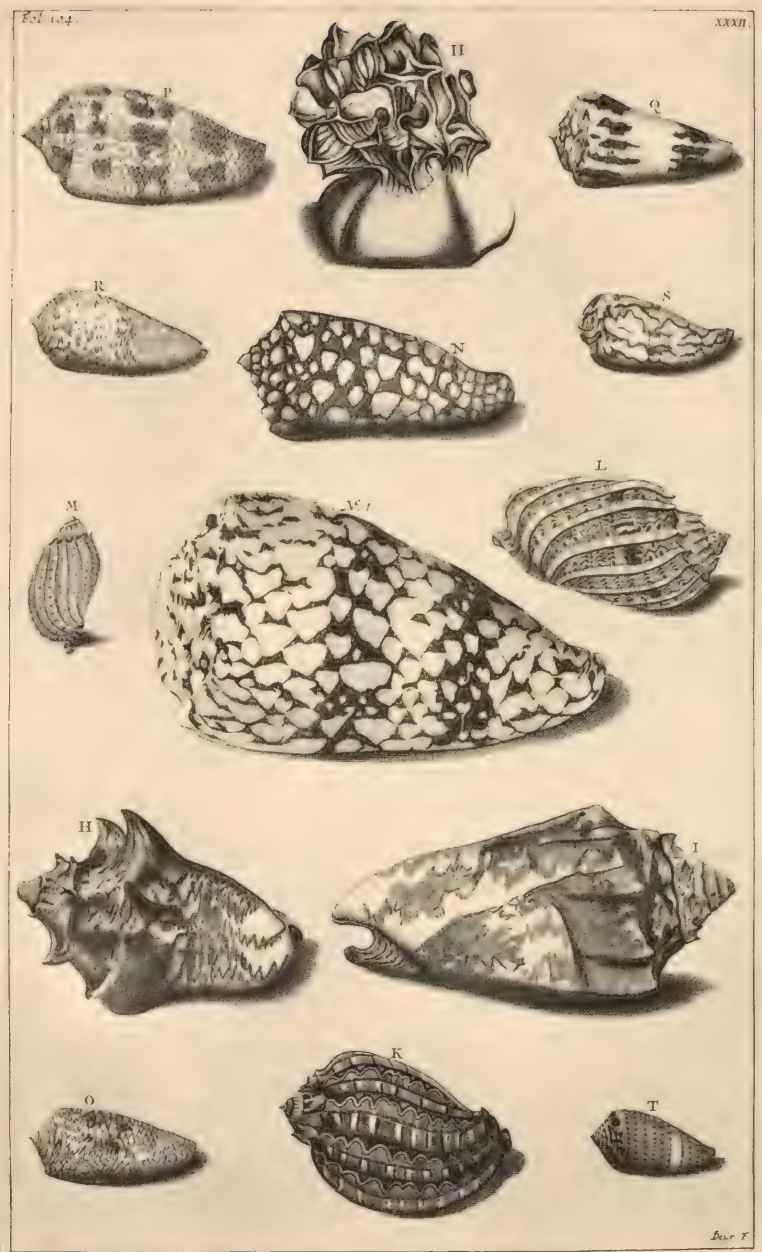


aardrijkskundige verspreiding over de Moluksche zeeën in den ruimsten zin.

Een groot bezwaar bestaat er tegen de bewerking van Rumphius' oorspronkelijke Rariteitkamer door den overigens zeer deskundigen Scinnvoet; deze heeft niet altijd streng acht geslagen op de vindplaatsen van bepaalde soorten, sommige naar zijn meening belangwekkende vormen ingevoegd, ook al behoorden ze in het geheel niet in den Indischen Oceaan thuis, en zoodoende den indruk gewekt, als zou Rumpiris zoo nu en dan van overal bijeenverzamelde schelpen als Moluksche beschreven hebben. Achter dit tweede boek is gevoegd een „Beschrijving en verdeeling der Amboinsche Hoornen en Schulpen" door Rumpirus' medewerker Sipman, door wien deze beschrijving gezonden was aan ,zijnen bijzonderen goeden vriend, den Heer J. DE JoNG", die de verhandeling weer aan Schynvoḱt heeft afgestaan. Met dit gedeelte, dat de bladzijden $187-193$ in beslag neemt, is de behandeling van het dierenrijk afgeloopen; deze beide boeken van de Amboinsche Rariteitkamer zijn dus alles, wat we thans nog van Rumpules' geschriften op zoölogisch gebied kennen. Vermelden we nu nog, dat in het reeds meermalen genoemde RumpHu's-gedenkboek Dr. J. G. DE Man een sleutel geleverd heeft op de Crustaceën in het eerste boek ${ }^{1}$ ), terwijl Prof. E. von Martens getracht heeft alle overige ongewervelde dieren, in de Rariteitkamer beschreven, te identificeeren en hun nomenclatuur in overeenstemming te brengen met de tegenwoordig heerschende opvattingen ${ }^{2}$ ).

Thans rest ons nog een indruk te geven in hoeverre Rumplic:

ז) J. G. IE MAN, 1902. Over de Crustacea (Weeke Schaalvisschen) in Rumphius' Rariteitkamer. (Rumphius-Gedenkboek. I902. p. 95-104).

2) E. von Martens, 1902. Die Mollusken (Conchyliën) und die übrigen wirbellosen Tiere im Rump'schen Rarititkammer. (Rumphius.Gedenkboek. I902. p. 109-136). 
G. E. RUMPHIUS.

een persoon ran beteekenis was voor de kennis der mineralogische, geologische en palaeontologische voortbrengselen onzer koloniën, en wij kunnen dit niet beter doen, dan met de woorden, waarmee Prof. WICHMann zijn belangwekkende studie hierover in het Rumprius-Gedenkboek ${ }^{x}$ ) besluit: ,De litteratuur vormt als het ware de roode draad, die de opvolgende geslachten met elkaar verbindt. Ten opzichte van de in de Rariteitkamer nedergelegde mineralogische en geologische gegevens is de draad verbroken geweest. Eerst tegen het einde van de 19 e eeuw heeft men een aanknooping tot stand gebracht, en zich het bestaan van zijn boek herinnerd. Zoodoende doet zich het zeldzame geval voor, dat een werk heden nog bijna even nieuw en belangrijk is, als 197 jaren geleden, toen het voor het eerst het licht zag. Dit voorrecht heeft Rumpurus te danken aan de nauwkeurigheid zijner waarnemingen, en ook aan de vertrouwbaarheid der door hem gewonnen inlichtingen, in welk opzicht hij onovertroffen is. Hij heeft daardoor oneindig veel meer nut gesticht, dan door zijnen tijd zoek te maken met het uitwerken van theoriën, waarvoor de tijd nog niet gekomen was, en die voor een oplossing nog niet vatbaar waren. Dit heeft hem tevens bewaard voor het lot van zoo velen zijner tijdgenooten, die toen eenmaal ,beroemd" waren, maar voor wier werken men heden - zoo men ze nog ter hand neemt niets dan een glimlach over heeft. Ook de natuuronderzoeker van dezen tijd eert Rumphits als zijn uitnemenden leidsman en voorganger, wiens arbeid terecht genoemd wordt: ,monumentum aëre perennius" ". Zie, zoo spreekt een bekend geoloog als Prof. Wichmann in onzen tijd over de beteekenis van een natuurwetenschappelijk lief hebber als Rumphius van twee eeuwen her.

r) A. Wichmans, 1902. Het aandeel van Rumphius in het mineralogisch en geologisch onderzoek van den Indischen Archipel. (Rumphius Gedenkboek, 1902. p. $137-164)$. 
En inderdaad, ook in het zoo moeilijke en in zijn tijd nog volkomen braakliggende gebied der levenlooze natuur weet Rumputs zich verdienstelijk te maken; enkele der meest belangrijke van zijn waarnemingen zijn wel waard, hier kort vermeld te worden: hoogst kenmerkend is bijv. zijn beschrijving van de phosphorescentie in diamant, pas in $166_{3}$ door Borte ontclekt: ",de Diamant heeft", zegt hij, ,een klein, doch scherp blixemend ronksken, waardoor ik geenszins versta een uitvaarend vonksken. maar een klein lichtje of glans, het welk in den steen gezien word". Ook over de zoogenaamde eetbare aarde, dat zijn verschillende kleisoorten, die door de inlanders en vooral door hun vrouwen gegeten worden, doet hij ons tal van mededeelingen, terwijl bovenal zijn verdienste hierin gelegen is, dat zijn beschrijving der mineralen de eerste en totnogtoe bijna de eenige poging is om een topografische mineralogie onzer Indische koloniën samen te stellen. Natuurlijk moeten wij zijn berichten beschouwen in het licht, dat de toenmalige mineralogische wetenschap nog op zeer laag peil stond: een meening, dat mineralen, als diamant, als vruchten van den bodem beschouwd werden en daar langen tijd moesten liggen, alvorens ze rijp werden, een dergelijke meening kunnen we Rumpruus toch waarlijk niet euvel duiden. Des te mooier staat daartegenover zijn volkomen juiste opvatting omtrent wezen en aard der versteeningen; terwijl vele geleerden in Europa deze voorwerpen nog als ,lusus naturae", als spelingen der natuur, beschouwden. zag Rumprics zeer goed in, dat wij hier met overblijfselen van dieren te maken hebben: hij kende zijn fossielen uit de natuur zelve; hij vond ze op de plaats, waar ze tientallen eeuwen gelegen hadden en kreeg zoodoende een helderder inzicht omtrent hun beteekenis, dan menig Europeesch onderzoeker, die ze alleen in museum-collecties zag. Zoo herkende hij een aantal versteeningen als overblijfselen van tweekleppige schelpen (Lamellibranchiaten) 
G. E. RUMPHIUS.

of van koralen; enkele Ammonieten bracht hij in verband met cle hem bekende schaal van Argonauta; maar dat hij daarentegen de eigenaardige Belemnieten, die met geen enkel levend organisme eenige overeenkomst vertoonen, niet wist thuis te brengen, moeten we hem dat als een fout aanrekenen? En evenzoo, dat hij in volkomen overeenstemming met zijn tijclyenooten, van fossiele Zeeëgels, Echiniden, vermeldt, dat ze .,eenpaarig gelooft worden, dat met eenig groot onweer aldaar greworpen worden", ook dat is een mededeeling, waarvan nu de onjuistheid buiten twijfel is, maar die toen algemeen geloofd werd. En juist zijn vermeldingen van Ammonieten en Belemnieten hebben nu kort geleden door de onderzoekingen der Siboga-expeditie (1899), van Dr. R. D. M. VerbeEK ${ }^{\text {I }}$ ) en van Dr. G. Boem ${ }^{2}$ ), geleid tot hoogst belangrijke ontdekkingen over de aanwezigheid van Jura- en Krijtformaties in onzen Indischen Archipel.

Het zwakste staat Rumphus wel in de aan de eigenlijke geologie gewijde gedeelten; waar hierbij de feiten op den achtergrond treden, en het behandelde van meer theoretischen aard wordt, daar blijkt Rumphus te veel vast te zitten in zijn onwankelbaar vertrouwen op het scheppingsverhaal van Genesis I, den Zondvloed ten tijde van Noach, en dergelijke historische bijbelverhalen meer. Zoo verklaart hij de aanwezigheid van fossiele schelpen aan de oppervlakte van het land uit den Zondvloed; weliswaar denkt hij ook aan de mogelijkheid van landopheffing door vulkanische uitbarsting, maar hecht daaraan in dit geval geen waarde, ,want men vind ze binnen in 't land op zoodanige Bergen, en op zoo groote Eilanden, die buyten

I) R. D. M. VERBEeK, 19oo. Voorloopig verslag over eene reis door het oostelijk gedeelte van den Indischen Archipel in I899. Batavia, 1900. p. 48.

2) G. Воєнм, г900. Reise-Notizen aus Ost-Asiën. (Zeitschrift deutsch. geol. Ges. LII, 1900. p. 557). 
twyffel van 't begin der Scheppinge geweest zijn". Dat eveneens zijn verklaring van de werking der vulkanen niet de juiste was, is ook uitsluitend te wijten aan de gebrekkige opvattingen, dic toentertijd heerschten.

De Ambonsche Rariteitkamer is dus, al was het werk misschien vooral bestemd voor Europeesche liefhebbers van rariteiten, al waren de wetenschappelijke mededeelingen misschien geen hoofdzaak, toch een werk van groote waarde, ook nog voor den tegenwoordigen onderzoeker op onze Indische eilanden. Des te meer valt het te betreuren, dat het Dierbock niet bekend is in den vorm, dien Runphrs eraan gegeven heeft; Valentyn, in wiens Oud- en Nieuw-Oost-Indiën het vermoedelijk geheel verwerkt is, legde zich meer toe op mooien stijl en keurige zinswendingen, dan op betrouwbaarheid; vandaar dat we RuMphits' werk niet naar VALENTyns boek mogen beoordeelen.

Behalve nu deze beide standaardwerken, Kruidboek en Rariteitkamer, zijn er hier en daar nog enkele mededeelingen van Rumphics verschenen; een aantal brieven aan Cirr. Mientzei. werden door dezen opgenomen in de Ephemerides van de Academia Naturae Curiosorum (1693). Ook daarin vinden wij tal van belangwekkende mededeelingen o.a. over kruidnagelen, over het lichten der zee, waarvoor hij geen goede verklaring weet te vinden en dat door hem ook in de Rariteitkamer besproken wordt (blz. 250). Bovendien stond Rcmpnus in briefwisseling met een aantal geleerden, vooral in Indië zelf: Gouverneur-Generaal Campulys, Herbert de Jager, Willem the Ruyne, Andreas Cleyer en anderen; ook met Europeesche geleerden correspondeerde hij veel. Helaas is over Ruminis' briefwisseling weinig bekend; terecht wordt in de RumpHit:bibliographie gezegd: „De studie, die naar waarheid teruggeeft, hoe aanzienlijk veel Rumpuus gecorrespondeerd heeft met 
allerlei soort van personen, geleerden en ongeleerden, doch allen belangstellenden, alles ter vermeerdering van zijn kennis, alles vooral ter verrijking van zijn Kruidboek en zijn Rariteitkamer,... deze zeker hoogst belangwekkende studie moet nog geschreven worden"!

Rumphics woonde weliswaar in een uithoek der wereld, verstoken van dagelijkschen omgang met andere geleerden, maar toch niet geisoleerd. Zijn verdienstelijke werkzaamheid werd algemeen bekend; van allerlei kanten trachtte men hem hiervoor te huldigen; de Heeren Bewinthebberen deden op hun manier het hunne om te toonen, hoezeer ze zijn arbeid op prijs stelden. Zij moedigden hem steeds aan op den ingeslagen weg voort te gaan en wisten werkelijk zijn Kruidboek naar waarde te schatten; zijn zoon Paulus Augustus werd, zooals we zagen, benoemd tot koopman, ,omme die pryselycke moeyte niet onbeloont te laeten, en voornoemde Rumphics bij provisie eenigermate dieswegen te remunereren".

Ook uit wetenschappelijke kringen werd hem getoond, van hoe groot belang men zijn pioniersarbeid in de tropen achtte; vermoedelijk op aanbeveling van zijn twee vrienden CLEvER en Mentzel werd hij in 168 I benoemd tot lid der Academia Naturae Curiosorum; hem werd volgens de in dat genootschap heerschende merkwaardige gewoonte de bijnaam „Plinius Indicus” gegeven. Groed bedoeld was deze ,cognomen” zeker en de leden der Academia wilden hiermede vooral uitdrukken, hoezeer Rumphics' werkkracht en veelzijdigheid hun verdienstelijk voorkwam; maar toch kunnen we DU PetiT Thouars geen ongelijk geven, als hij in zijn korte levensbeschrijving van Rumphus ${ }^{x}$ ) in de Biographie Universelle de volgende opmer-

1) L. M. A. A. Du Petit-Thouars, 1825. Artikel: „Rumpf, (George EveraRd)" in: Biographie Universelle ancienne et moderne . . . rédigée par une Société de gens de lettres et de savants. (Tome 39. p. 317-322). p. 319a. 
king maakt: "C'était pour cela que, suivant son usage, cette compagnie savante l'a nommé Pline par autonomase; mais il y avait cette différence que Pline l'Ancien avait adopté souvent sans examen ce que ses prédécesseurs lui avaient transmis, tandis que le Nouveau avait vérifiée par lui-même tout ce qu'il avait annoncé de plus extraordinaire".

Dat in den tegenwoordigen tijd de vereering door wetenschappelijke personen niet minder is, blijkt wel ten duidelijkste uit de reeds vermelde woorden van Prof. Wichminn (zie blz. 54), maar vooral ook uit de algemeene instemming, die aan de in 1902 door het Koloniaal Museum georganiseerde Rumphiusherdenking is ten deel gevallen. Tal van geleerden, botanici, zoölogen, geologen, historici, werkten daarbij samen om een zijner waardig Rumphius-Gedenkboek tot stand te brengen en inderdaad is deze Hollandsch-Duitsche eendracht met groot succes beloond. Bovendien werd hem ter eere een Rumphiusmedaille geslagen en een Rumphiusfonds gesticht met het doel deze Rumphius-medaille in goud periodiek toe te kennen ,aan natuuronderzoekers, die geoordeeld worden groote verdiensten zich verworven te hebben voor het onderzoek van den Nederlandsch-Indischen Archipel, bepaaldelijk het oostelijk gedeelte daarvan" "). Is het voor een land als het onze, met een zoo groote bron van inkomsten in de koloniën niet een betreurenswaardig feit, dat dit zoo sympathieke fonds pas ongeveer $f 7000$ bedraagt, waarvan de helft uit één legaat afkomstig? Hoe lang zal het nog moeten duren, voor de grootsche gedachte van Greshoff: "Indien eenmaal de Molukken uit hun huidige lethargie gewekt worden, dan zal er te Hila op Amboina een „Rumphius-station" moeten verrijzen als centrum voor 't natuur-

x) Zie Inleiding Rumphius.Gedenkboek. 1902. (p. VIII) en Bijlage van het Bulletin Kolon. Museum. No. 28 (p. 12 noot). 
historisch onderzoek der door Nederland zoo verwaarloosde Molukken" verwezenlijkt wordt? Waarlijk, ons land kan een man als Ruxpulcs niet genoeg in eere houden; op tal van onderzoekingsgebieden was hij de baanbreker: voor het systematisch onderzoek der flora en fauna van Indië heeft hij ons een voorbeeld gegeven als geen ander, een voorbeeld, dat totnogtoe te weinig navolging gevonden heeft. En daarbij werkte en schreef Rumpulus met een bescheidenheid en een nauwgezetheid, als helaas in personen van wetenschap te vaak ontbreken. "All for love, nothing for reward", het woord, dat Prof. Goebel ${ }^{1}$ ) als motto boven het Kruidboek zou willen plaatsen, is zoo volkomen juist gekozen.

Hoe Rumphics vanuit Europa aangemoedigd werd met zijn studiën voort te gaan, hebben we gezien; nog te vermelden valt het blijk van belangstelling, dat hem Cosimo III DE MEdicI, Groothertog van Toskane, gaf door een uitgezochte collectie „,rariteiten" waaraan RumpHus jarenlang gewerkt had, van hem als geschenk aan te nemen. Als mooi resultaat van de Rumphiusherdenking mag wel gelden het terugvinden van alle daarop betrekking hebbende papieren, waaronder brieven van RumpHIt's, en enkele voorwerpen daaruit, in het museum te Florence. Een groot deel dezer collectie, vooral schelpen, bevindt zich thans in het Staatsmuseum te Weenen.

De I $5^{\text {de Juni }}$ I 702 was een belangrijke dag voor het natuuronderzoek van Indië; een dag, waarop de eerste periode van bloei, die wij danken aan krachtige figuren als VAN REEDE en Ruishius door het overlijden van den laatste afgesloten werd.

De belangrijke ontwikkeling van dit natuuronderzoek in de zeventiende eeuw lag dus voornamelijk op het gebied van

$\left.{ }^{2}\right)$ K. Goebel, igo2. Rumphius als botanischer Naturforscher. (RumphiusGedenkboek. r902. p. 59-62). 
flora- en fauna-bestudeering; hier en daar werden de ecrste pogingen gedaan tot onderzoek der eigenlijke biologie, terwijl de anorganische natuurwetenschappen nog zeer weinig beoefend werden. Wat daarover in dien tijd gewerkt is, is uitsluitend het zeer primitieve scheikundig onderzoek der mineralen in Rumphius' Rariteitkamer Boek III, waarbij vooral een criterium was, of de mineralen in limoensap kookten en een enkele optische waarneming, als bijv. de phosphorescentie van diamant. Zoo is het jaar I7O2 geworden een punt van scheiding tusschen een bloeiperiode en de volgende "steriele" achttiende eeuw. 


\section{HOOFDSTUK III.}

\section{De achttiende E e uw.}

$1702-1816$.

Scherp is de tegenstelling tusschen het Indisch natuuronderzoek in de gouden eeuw en in het volgend tijdvak, dat een aanvang neemt na Rusphics' dood (I702) en zich meer dan honderd jaren lang voortzet tot de teruggave van onze koloniën door de Engelschen (1816): de gouden eeuw getuigend van opgewekt leven, van doelbewuste natuurstudie, zij het dan ook slechts door weinige personen, met als schitterende resultaten de grootsche werken van een VAN ReEde en een Rusphiu's; haar opvolgster getuigend van één droevig lijden: een enkele, die zijn krachten geven wil, wordt daarin door de koopmansstaatkunde der Compagnie gedwarsboomd.

Voor de Compagnie zelf was het begin der achttiende eeuw een tijdperk van uitwendigen, van schijnbaren bloei, van oogenschijnlijk belangrijke welvaart, tenminste van groote winsten. Schatten werden verdiend; aandeelen en uitkeeringen stegen al hooger en hooger; jaarlijksche dividenden van 30 , ja 40 procent waren geen zeldzaamheid; aandeelen werden verhandeld tegen het twaalfvoud hunner oorspronkelijke waarde. Steeds meer 
gebied werd aan het bezit der Compagnie toegevoegd; krachtige bestuurders en tactvolle admiraals werkten samen om het aanzien der Souvereine Maatschappij te vergrooten.

En toch waren deze kenteekenen van bloei uitwendig: de Compagnie had haar hoogtepunt reeds overschreden; innerlijk begon een periode van geleidelijk verval. Als zoo vaak had ook hier toenemende welvaart een verslapping van het geestelijk leven ten gevolge: het persoonlijk karakter harer ambtenaren liet dikwijls te wenschen over; de zorg voor geestelijke belangen werd op den achtergrond gedrongen, waar het geld al meer en meer macht kreeg en steeds meer zijn invloed deed gelden. „Het geheele raderwerk der inwendige administratie was allengs een zoodanig weefsel van intrigues geworden, dat de Compagnie nauwelijks meer op bekwame of eerlijke dienaren rekenen kon, en diefstal en onrecht, aan het algemeen belang gepleegd, niet alleen straffeloos geduld, maar verontschuldigd en zelfs beloond werden" ${ }^{ }$).

Waar zulke toestanden heerschten, was uit den aard der zaak onder de ambtenaren der O.-I.-C. iemand, begaafd met liefde en aanleg voor wetenschappelijk onderzoek, een witte raaf; temeer waar de Hooge Regeering maar zelden blijken gaf, dergelijke onderzoekingen te willen steunen en tot de openbaarmaking ervan te willen medewerken. De houding van het Indisch Bestuur gedurende deze eeuw tegenover iedere uiting van wetenschappelijke werkzaamheid, wordt wel het best gekenmerkt door de woorden, waarin uitgedrukt was de voorwaarde, gesteld aan den Hoogleeraar Donati, die zich ., met voorschrijving der Kamer van Zeventienen tot wetenschappelijke nasporingen naar Batavia begeven had, wien dan ook, uit dien hoofde, de Indische Regeering de noodige hulp daartoe beloofde,

1) H. BusNk, 19r3. Een ecuw van koloniaal bewind. (Vragen van den Dag. 1913. p. $513-605)$. p. 523 . 
doch met het bekrompene bijvoegsel, ,van tevens te zullen zorgen, dat die heeren hunnen weetlust alleen bij voorwerpen hunner studie bepaalden, en gelijk niet zelden gebeurd is, geen misbruik van het verleende verlof zouden maken" " $)$.

Weinigen waren er dan ook, die zich, ondanks de geringe belangstelling van de zijde der Regeering, toch aan werk in dienst der Wetenschap wijdden, en niemand toonde een zoo grootsche gave en een zoo onuitputtelijke werkkracht, als de grootste der zeventiende eeuw, Rumphius.

François Valentro, jonger dan Rumphics en in vele opzichten zijn leerling, was een man van ongetwijfeld groote gaven, van een aanzicnlijke werkkracht, maar zonder veel oorspronkelijkheid. Een volkomen rechtvaardige beoordeeling van VALENTINS werk op het gebied van Indisch natuuronderzoek te geven, is een uiterst moeilijke taak; aan den eenen kant komen we onder den indruk van zijn overweldigend groote kennis en het omvangrijke feitenmateriaal, waarvan zijn Ouden Nieuw-Oost-Indiën ${ }^{2}$ ) een zoo schitterend getuigenis aflegt; maar daartegenover moeten we voortdurend in het oog houden,

I) N. G. VAN KAMPen, $183 \mathrm{I}-18_{33}$. Geschiedenis der Nederlanders buiten Europa. (3 dln. in 4 bdn. Haarlem. I. IS 31 ; II. I831; III. I. I832; III. 2. I833). III. I. p. 169 .

${ }^{2}$ ) De titel luidt:

Oud en Nieuw || Oost-Indiën, || vervattende || Een Naaukeurige en Uitvoerige Verhandelinge van || Nederlands Mogentheyd || In die || Gewesten, || Benevens || Eene wijdlustige Beschrijvinge der Moluccos, Amboina, Banda, Timor, \| en Solor, Java, en alle de Eylanden onder dezelve Landbestieringen || behoorende; het Nederlands Comptoir op Suratte, en de || Levens der groote Mogols; |l als ook \|Een Keurlijke Verhandeling van 't wezenlijkste, dat men behoort te weten van $\|$ Choromandel enz. enz. \| door || François Valenty , \| Onlangs Bedienaar des Goddelijken IVoords in Amboina, Banda, enz. || in vijf deelen. \|
Te $\left\{\begin{array}{c}\text { Dordrecht } \\ \text { Amsterdam }\end{array}\right\}$
Joannes van Braan,
, Boekver-
bij \{
Gerard Onder De Linden, koopers.
MDCCXXIV.
Met Privilegie. 



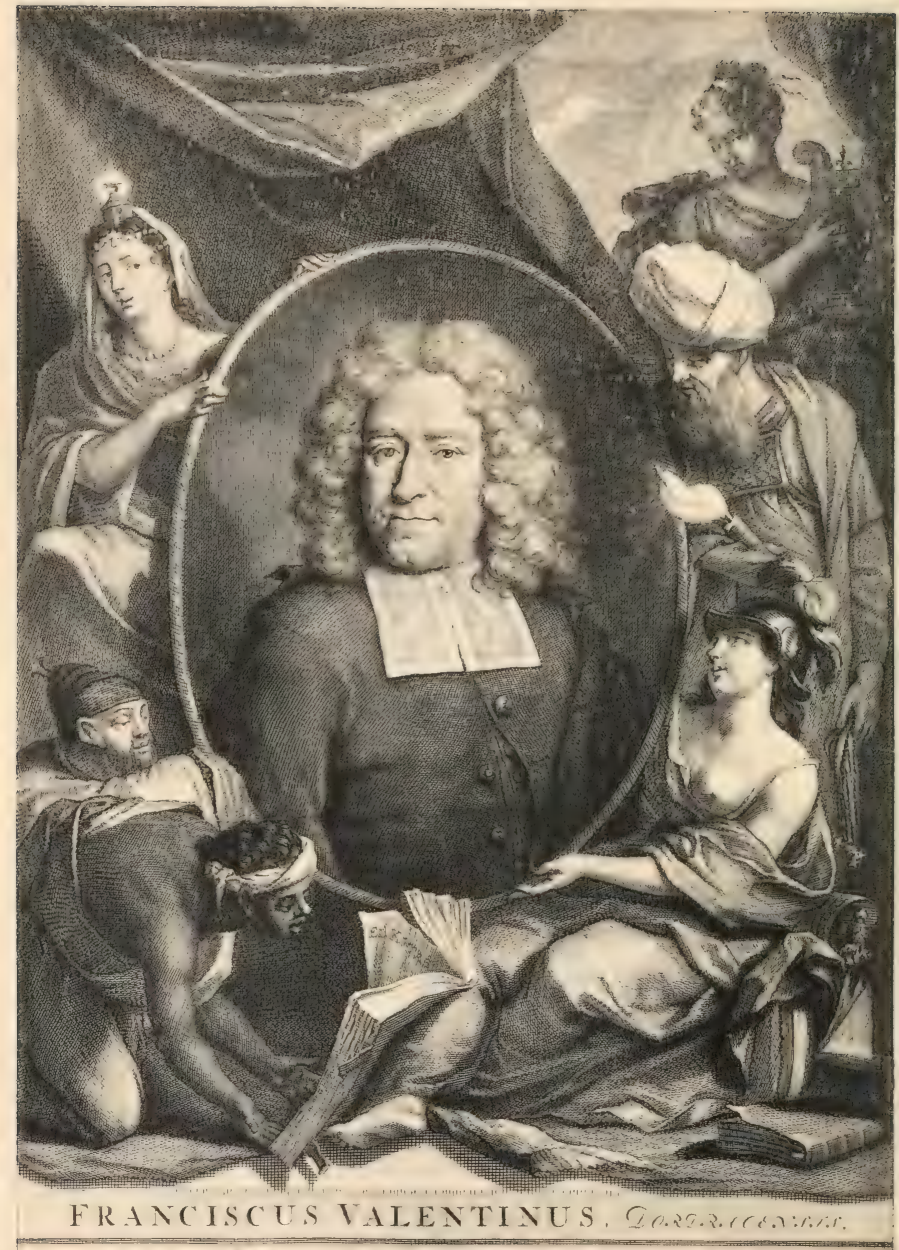

vipe. VERBI DIVINI MINISTER AYBOIXFXSIS.tiat: 
van hoe weinig originaliteit en hoe weinig eerlijkheid zijn handelwijze met betrekking tot Rumpir's' Dierboek (zie blz. 47) ons spreekt. Valentyn was een werker in den goeden zin des woords, maar hij was ook een ijdele persoonlijkheid, die zich niet schaamde, handschriften van zijn overleden leermeester en verwant Rumphius als de zijne uit te geven.

Dordtenaar van geboorte (I666), gaf hij reeds als jongen van een jaar of twaalf blijk van grooten aanleg en van buitengewonen ijver, vooral op taalkundig gebied, studeerde theologie en was reeds op zeventienjarigen leeftijd proponent, vertrok Mei 1685 naar den Oost, waar hij spoedig na aankomst "door zijn innemend gedrag en gepaste vrijmoedigheid", zegt VAN Kampen $^{\mathrm{I}}$ ), met den Gouv.-Gen. Canphuss in kennis kwam, die hem op zijn verzoek als prediker naar Ambon zond. Hier kwam hij onder invloed van Rumphits, die hem een leermeester was voor de Maleische taal en door wiens hulp hij ook met Ambons natuurlijke gesteldheid vertrouwd raakte. Op Ambon vertoefde hij van 1686 tot 1694 , welk verblijf echter onderbroken werd door een verplaatsing naar Banda, vanwaar hij na een tienmaandsche afwezigheid weer naar Ambon terugkeerde. In I 694 vertrok hij naar het vaderland, om eerst in I705 naar Indië en in I707, dus lang na Rumpinus' dood, naar Ambon weer te keeren, in 17I4 voorgoed de tropen te verlaten en zich in het vaderland te vestigen, waar hij de uitgave van zijn Oud- en Nieuw-Oost-Indiën verzorgde (I 724 - I 726 ).

VALENTINS werk op natuurwetenschappelijk gebied maakt geheel den indruk van compilatie-arbeid, van een ineenvlechten van talrijke belangwekkende bijzonderheden, die hij aan anderer werk, en wel voor een deel aan het handschrift van Rumpinus' Dierboek ontleende. Van oorspronkelijk natuuronderzoek, van

ז) N. G. van Kampen, 183r. II. p. 398. 
DE ACHTTIENDE EEUW.

zelfstandige beoefening der natuurwetenschap was bij hem eigenlijk geen sprake; hij was in de eerste plaats letterkundige en zocht maar al te vaak zijn kracht in mooie zinswendingen, in gezwollen taal en in omhaal van woorden. De meening van VAN Kampen ${ }^{\mathrm{I}}$ ): „Gelijk Rumphius de voortbrengselen van Amboina en den omtrek voor den Natuurkundige beschreven heeft, zoo heeft VALENTyn zulks voor den gewonen lezer en liefhebber gedaan, en maakt daarom ook geene aanspraak op bijzondere botanische of zoölogische kunde of rangschikking, maar slechts op de gave van goede en nauwkeurige waarnemingen", lijkt mij dan ook in drie opzichten onjuist, en wel: I e was Rumphius' Rariteitkamer veeleer een goed populair boek, dan Valentyns werk; $2 \mathrm{e}$ maakte Rumphius ook geen ,aanspraak op bijzondere botanische of zoölogische kunde of rangschikking", en $3^{\mathrm{e}}$ waren de ,goede en nauwkeurige waarnemingen" niet van VALENTyN, maar van anderen.

Daarmede is echter volstrekt niet gezegd, dat Valentyns Oud- en Nieuw-Oost-Indiën voor onze kennis der natuur waardeloos zou zijn; het boek bezit ontegenzeggelijk groote verdienste en is nog steeds een belangrijke bron van ons weten, maar daartegenover is een lofprijzing als een boek, waarin ,al hetgeen hij ons heeft medegedeeld het kenmerk van eenvoudigheid en waarheidsliefde draagt" " ${ }^{2}$, even onjuist als onverdiend.

Zelfstandig natuurwetenschappelijk onderzoek is in de achttiende eeuw schaars, vooral op het gebied der organische natuur. Dank zij de koopmansstaatkunde der O.-I.-C., die zelfs reizen naar het binnenland als weglooperij en vagabondage beschouwde en met kettingstraf bedreigde, is dan ook de geheele periode van het begin der eeuw tot 1778 een trooste-

I) N. G. van Kampen, I83r. II. p. 399.

2) W. R. vaN Höevell, 1839. p. 35 . 
looze woestenij, waarin zich slechts hier en daar kleine oasen bevinden.

Enkele bijdragen in dezen tijd tot onze kennis der tropenwereld danken wij aan een klein getal expedities, die meest met politieke doeleinden uitgerust werden en wier leden nu en dan een gedwongen oponthoud op een der eilanden gebruikten, om flora en fauna en vooral de nuttige gewassen te bestudeeren. Het meeste resultaat hebben wel opgeleverd de tochten van Bovgainville, van James Cook en van Provost.

Bougainville's tocht, die tot voornaamste doel had de Falklandseilanden aan Spanje terug te geven, was een reis om de wereld ( I 766-i769), waarop van onze koloniën bezocht werden Boeroe, Boeton, Saleyer en Java. Als natuuronderzoeker ging mee Commerson, die in 1773 op Mauritius stierf en dus waarschijnlijk geen deel had in BougainviLle's reisbeschrijving. Commersons plantenverzamelingen bevinden zich in Parijs en Genève.

Ook James Cook werd op zijn eerste reis ( 1768 - I 77 I) door den natuuronderzoeker Sir Joseph Banks vergezeld, die zich in onzen Archipel vooral met het verzamelen van visschen bezig hield, terwijl de Fransche onderzoeker P. Sonnerat zich aansloot bij een door Porvre, den Gouverneur van Mauritius uitgeruste expeditie onder bevel van Provost. Deze expeditie, die in de jaren $1771-177^{2}$ plaats vond, is van het drietal de meest succesvolle geweest; Sonnerat keerde in 1773 naar Frankrijk terug, waar in 1776 zijn reisverhaal als boek verscheen ${ }^{\mathrm{x}}$ ). In 't bijzonder mogen zijn vogelplaten genoemd worden en zijn beschrijving van muskaat en kruidnagelen in de Molukken.

I) P. Sonnerat, 1776. Voyage à la Nouvelle Guinée [par les Séchelles et les Philippines] dans lequel on trouve la description des Lieux, ...... et des détails relatifs à l'Histoire Naturelle dans le Regne Animal et le Regne Végétal. Paris 1776. Duitsche vertaling: Reise nach Neu-Guinea. Leipzig 1776. 
Maar gelukkig was onder' de Nederlanders in de koloniën de liefde voor de natuur nog niet geheel ingeslapen, het voorbeeld van Nicolans Witsen, den Amsterdamschen Maecenas, die steeds bereid was wetenschappelijk onderzoek te steunen en de kosten van ontdekkingsreizen op zich te nemen ${ }^{\mathrm{x}}$ ) en die ook op zijn kosten een keurcollectie teekeningen van Javaansche planten maken liet, welke verzameling zich thans in Teylers Museum bevindt ${ }^{2}$ ), wekte navolging. Met behulp van teekeningen, grootendeels door Samuel Fallours, ziekentrooster op Amboina, gemaakt, vermoedelijk met steun van den Amboinschen Gouverneur Balthasar Covett en door Cornelis de Vlaning uit Indië meegebracht, bewerkte Louis Renard, agent van den Koning van Frankrijk te Amsterdam, omstreeks I 720 zijn groote werk over de Moluksche visch- en kreeftenfauna ${ }^{3}$ ).

Maar het meest in bijzonderheden bekend zijn de lotgevallen der teekeningen, vervaardigd door den kunstenaar J. C. Loten $\left.{ }^{4}\right)$. LOTEN, als onderkoopman in I73I naar Indië gegaan, werd spoedig aangesteld als fiscaal van java's Noordkust, met standplaats Semarang, keerde I74 I naar Batavia terug, vertoefde I744-I750 als Gouverneur van Makassar op Celebes, werd benoemd tot Raad extraordinaris en in 1752 tot Gouverneur

I) Zie over NicolaAs Witsen het boeiend geschreven artikel: M. Greshoff, 1909. NicolaAs Witsen als Maecenas. (Album der Natuur. 1909. p. I25-I53. m. portr.).

2) Zie D. Lubach, i 867 . Notes bibliographiques. II. Plantae javanicae pictae. (Archives du Musée Teyler. I. p. 140-I43).

En D. Lubach, i880. Teekeningen van Javaansche planten, bezorgd door NicolaAs Witsen. (Album der Natuur. I880. p. 3i-32).

3) L. Renard, 1754. Poissons, écrevisses et crabes de diverses couleurs, et figures extraordinaires, que l'on trouve autour des Mouluques et sur les côtes des terres australes. Amsterdam. 1754. fol. De catalogus der bibliotheek-TEYLER vermeldt het bestaan van een $\mathrm{I}^{\text {en }}$ druk van $\mathrm{I} 7 \mathrm{I} 8$.

4) P. J. van Houten, I906. Twee natuurlief hebbers uit de ise eeuw. (Bulletin Kol. Mus. Haarlem. No. 34. 1906. p. 7I-8I). 
van Ceylon. Hier was het, dat Loten, die vroeger zelf zich met het teekenen van Indische dieren had beziggehouden, het teekentalent ontdekte van DE BEvere, een jongen man van grootendeels inlandsche af komst. De BEvERE wordt door Loten in huis genomen en eenigszins in de teekentechniek onderricht; LOTEN zegt van hem in een zijner brieven, dat hij was ,een jongeling, van inlandsche Ceylonsche ouders geboren, bij mij inwonende en mij zeer veel in het afteekenen helpende". Het blijkt dus, dat ook LOTEN zelf zich nog tijdens zijn verblijf op Ceylon. met teekenen bezighield. Het kunstenaarstalent van DE BEvere ontwikkelde zich schitterend; streng nauwgezet werker, fantaseerde hij nooit, gaf hij met een bewonderenswaardige vaardigheid en vastheid van hand lijnen en kleuren weer, yoornamelijk van vogels, maar ook wel van zoogdieren, visschen, planten, enz. LOTEN maakte bij al deze platen ,Aanteekeningen om indertyd te kunnen dienen tot het in order brengen van het geene ik successive heb verzameld zo in tekenen naar het leeven als geschrift om eenig licht te kunnen bybrengen tot de Natuurlyke Historie van Oost-Indiën en voornamelyk van Java, Celebes en Ceylon". Bij Loten's vertrek van Ceylon naar Batavia als ,Raad ordinair van Indië" ging De Bevere mee, die ook daar teekeningen vervaardigde o.a. van aldaar aangebrachte Moluksche papegaaien. In 1758 repatrieerde Loten als Admiraal der retourvloot, vestigde zich daarna te Fulham bij Londen, later te Utrecht, waar hij 25 Februari 1789 overleed $^{\mathrm{I}}$ ).

Het was dus wel geen wetenschappelijk onderzoek, dat door

1) Van Lotex's platenverzameling is o.a. gebruik gemaakt voor de illustratie van G. EDwards, 1758. Gleanings of natural history, exhibiting figures of quadrupeds, birds, insects, plants, etc. Most of which have not, till now, been either figured or described. With descriptions of seventy different subjects, designed, engraved and coloured after nature on fifty copper-plate prints. London, 1758. 
DE ACHTTIENDE EEUW.

al deze bekende en onbekende kunstenaars beoefend werd, veeleer een uiting van liefde voor het schoone, kleurenrijke en indrukwekkende der Indische dierenwereld. Onderzoek van zuiver wetenschappelijken aard, naspeuringen over het leven der dieren ontbreken in deze eeuw geheel.

Eén richting van natuurwetenschap was er, die buiten het bereik der Compagnies-achterdocht viel en wier licht niet verduisterd worden kon door de invloedrijke domperpolitiek dier dagen, namelijk de sterrenkunde. In de inleiding zagen we reeds, hoe door de zeevaarders onzer zestiende eeuw, door de Houtmans, Huygen van Linschoten, en zooveel anderen hier en daar wetenschappelijk sterrenkundig onderzoek was verricht, weliswaar zonder veel systeem en meer met het oog op de practische resultaten, maar toch als pioniersarbeid vermeldenswaard. Dat was ook het eenige gebied, waarop in de achttiende eeuw, tenminste in de eerste helft, zelfstandig onderzoek in onze koloniën verricht werd.

Onder de Indische predikanten was te dien tijde een wetenschappelijke drang merkbaar, die zich meest kenbaar maakte in taal- en letterkundige studiën, in bijbelvertaling en in vertaling van Javaansche en Maleische sagen, maar zich ook wel eens in natuurwetenschappelijke richting bewoog. Zoo was de eenige zelfstandige werker in dien tijd een predikant, JoHAN Maurits Mohr, geboren (Aug. i7 I6) Duitscher, maar reeds op I6-jarigen leeftijd te Groningen als student ingeschreven. Even twintig jaar oud, werd MoHr voor de Indische kerken aangenomen, deed eerst eenigen tijd dienst bij leger of vloot en aanvaardde in Februari 1739 het predikambt bij de Portugeesche Gemeente te Batavia. MoHr's predikantenloopbaan was een glansrijke, al waren er, vooral in het begin, tallooze moeilijkheden voor hem te overwinnen. O.a. bekleedde hij van I 745 tot 1753 het rectorsambt van het door den G.-G. Van ImHoff 
opgerichte Seminarium te Batavia ${ }^{2}$ ). Omstreeks 1750 begint MoHr zich op sterrenkundige studiën toe te leggen; tenminste in dat jaar en enkele volgende jaren worden hem door den Leidschen hoogleeraar Johannes Zuloffs en een zekeren J. PAAUW Jr., misschien instrumentmaker, boeken en instrumenten gezonden: astronomische verrekijker, heliometer, pluviometer, zee-octant, enz. In I76I werd door hem voor het eerst de ware lengte van Batavia vastgesteld, in welk jaar hij de passage van Venus over de zon waarnam. Batavia's ligging bepaalt hij op $6^{\circ} 9^{\prime}$ zuiderbreedte en $106^{\circ} 50^{\prime}$ oosterlengte van Greenwich. Maar dit betrekkelijk primitief ingerichte onderzoek geeft MoHR geen bevrediging; hij moet een observatorium hebben, om zich daar geheel in zijn astronomische studies te verdiepen. Van de O.-I.-C. is geen hulp te verwachten; er blijft hem niets anders over, dan zelf een gebouw te stichten, waartoe hem zijn groot fortuin in staat stelt. Hoe Molr zoo onmetelijk rijk geworden is, is onbekend; $V_{\text {Етн }}{ }^{2}$ ) vermoedt, dat zijn huwelijk met de Weduwe VAN Gehren , ,de voorname bron van zijn rijkdom zal geweest zijn". In ieder geval was MoHr niet rijk, toen hij Europa verliet en kunnen we ons niet voorstellen, dat hij van de 90 gulden 's maands, welk salaris later tot 130 gulden verhoogd werd, ,onmetelijke rijkdommen” overlegde, ook al nemen we in aanmerking, dat het rectoraat van het Seminarium hem IOo० gulden per jaar extra opbracht.

"De heer MoHR", schrijft de reeds genoemde wereldreiziger Botgainville ${ }^{3}$ ), ,eerste leeraar van Batavia, een man van onmetelijke rijkdommen, maar veel achtingswaardiger door zijne

r) Zie P. J. Veth, i885. Johan Maurits Mohr (Gids, i885. 4e Serie. $3^{\text {e Jrgng. }}$ III. p. $55-87$ ). p. 69 .

2) P. J. VeTH, 1885. p. 67 .

3) Zie P. A. LeuPE, I864. Iets over den Nederlandschen Sterrekundige Johan Maurits Mohr te Batavia. (Bijdr. tot de taal, land-en volkenkunde van Ned.-Indië. Nieuwe volgreeks. Zevende deel. 1864. p. 160-I6S). p. 162. 
DE ACHTTIENDE EEUW.

kundigheden en geneigdheid tot de wetenschappen, heeft aldaar - Batavia - in een tuin van een zijner lusthuizen, een sterreschouwplaats, die ieder koninklijk geslacht eer zoude aandoen, laten oprigten". Verder vindt Bougainville ,het lofwaardigste" in dezen sterrekundige, dat hij, ,die buiten kijf de rijkste der kinderen van Urania is, er zelf waarnemingen doet".

Het was Morrs bedoeling, het observatorium gereed te hebben voor Juni I 769 , wanneer weer een overgang van Venus voor de zon verwacht werd, en inderdaad vinden wij dan ook in de Verhandelingen van de Holl. Maatschappij van Wetenschappen te Haarlem ${ }^{\mathrm{I}}$ ) een "Waarneming van Venus bij haren

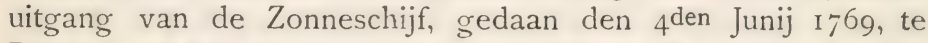
Batavia, op het observatorium, leggende op 6 graden 12 minuten zuider breedte". Reeds vroeger had MoHr aan de Holl. Maatschappij zijn waarnemingen over den overgang van 6 Juni 176I gezonden, en deze opgenomen gezien in het VIIle deel der Verhandelingen ${ }^{2}$ ). Toch geven deze uiteenzettingen den lezer een onbevredigenden indruk; wij vinden in deze mededeelingen, evenals in een derde, naar aanleiding van den overgang van Mercurius over de zon (IO Nov. $1769^{3}$ ), slechts vermelding van de gebruikte instrumenten, opgave van de omstandigheden, waaronder de waarnemingen geschiedden, en die alleen ten opzichte der binnen- en buitenaanraking van de randen der hemellichamen bij den uitgang der planeet van de zonnevlakte, voldoende nauwkeurigheid toelieten, en een zeer beknopte opgave der voorloopig bereikte resultaten. Moнk belooft spoedig de daaruit afgeleide berekeningen van Batavia's lengte te zullen mededeelen, maar hij heeft deze belofte niet gehouden, of zijn berekeningen zijn verloren gegaan. Ten-

I) Verhandelingen Holl. Mij. van Wet. Haarlem. XII. Berichten. p. 123-r30.

2) Verhandelingen Holl. Mij. van Wet. Haarlem. VIII. p. 380 .

3) Verhandelingen Holl. Mij. van Wet. Haarlem. XII. Berichten. p. I3I-134. 
minste in de verdere Verhandelingen der Holl. Maatschappij is daarvan niets te vinden. Het eenige, wat nog verder van MoHR's astronomisch werk bekend is, zijn de mededeelingen, door bemiddeling van Cook geplaatst in de Philosophical Transactions (1772), waar hij vermeldt, dat hij met behulp van Venus' overgang, van een aantal zonsmiddaghoogten, van eenige emersies en immersies van den eersten satelliet van Jupiter, en van twee maaneclipsen, de breedte van zijn Observatorium bepaald heeft op $6^{\circ} 10^{\prime}$ en het lengteverschil met de Parijsche sterrenwacht op $104^{\circ} 30^{\prime}$ (verschil Parijs-Greenwich $2^{\circ} 20^{\prime} 24^{\prime \prime}$, dus Batavia-Greenwich $\left.106^{\circ} 50^{\prime}\right)$, en opnieuw belooft, dat zijn waarnemingen ,zelfs binnen weinige dagen, zoo God wil, aan de Hollandsche Maatschappij, zullen worden overgemaakt". Ook hiervan is niets gekomen.

Behalve op het gebied der sterrenkunde, vestigde MoHr ook zijn aandacht op vulkanische verschijnselen: de ontzettende uitbarsting van den Papandajan, op den I Iden Augustus I772, een ramp, die ongeveer 3000 slachtoffers maakte, gaf hem aanleiding aan de Hollandsche Maatschappij te zenden een .,Berigt nopens het springen en instorten van den brandenden zwavelberg, met het droevige gevolg van dien op het eiland Java, in de maand Augustus I $77^{2}$, voorgevallen, met bijgevoegde aanmerkingen nopens dit verschijnsel" ${ }^{x}$ ).

MoHr overleed den 28en October I775. "Openhartig met zijne vrienden, meedoogend met ellendigen, bescheiden tegen allen" noemde hem zijn Bataviasche ambtgenoot VERMEer in zijn lijkrede; „Nimmer bezoedelde hij zijn leeven met dat vuil bedrijf, dat hier zoo meenig eenen de woorden in de keel deet smooren: nimmer werd zijne eerlijkheid en deugd, zelfs niet van de vuilste kwaadaardigheid, in verdenking gebracht; in alles

x) Verhandelingen Holl. Mij. van Wet. Haarlem. XIV. Berichten, p. $82-96$. 
DE ACHTTIENDE EEUW.

poogde hij eerlijk onder $u$ te wandelen en door reine en eenvoudige zeeden, door een vrolijke gemoedsgesteldheid veraangenaamd, u de deugd beminnelijk te maken".

Man van groote wetenschappelijke gaven, stond hij als mensch en als geleerde, bij allen in hoog aanzien, al zal misschien menig ambtenaar der O.-J.-C. moeilijk een glimlach van meerderheidsbesef hebben onderdrukt bij de gedachte, dat MoHr zulke schatten aan de wetenschap offerde: Indië was toch alleen goed, om er geld te verdienen, niet om het er uit te geven.

In het vaderland vinden wij in dezen tijd, na 1750 , een opleving van wetenschappelijk werk; in het bijzonder de natuurwetenschap werd hierdoor begunstigd: op verschillende plaatsen van ons land werden genootschappen gesticht ter bevordering van wetenschap en geestelijk leven; de gedachte, dat wetenschappelijk onderzoek een belangrijke bron van volkswelvaart kon zijn, had zich baan gebroken.

Zoo ontstaan achtereenvolgens in 1752 de Hollandsche Maatschappij der Wetenschappen te Haarlem, in 1769 het Bataafsch Genootschap der proefondervindelijke IVijsbegeerte te Rotterdam en het Zeeuwsch Genootschap der Wetenschappen te Vlissingen (in I90 I naar Middelburg verplaatst), en in 1773 het Provinciaal Utrechtsch Genootschap van Kunsten en Wetenschappen te Utrecht, waarvan de eerste twee zich in het bijzonder op natuurwetenschappelijk gebied bewegen, het derde vooral oudheidkundige studiën bevordert, terwijl het laatstgenoemde in den meest algemeenen zin wetenschappelijk onderzoek steunt.

Op initiatief van Mr. H. H. van DEN Heuvel, griffier van het Hof van Justitie te Utrecht, besloot de $25^{\text {ste }}$ Algemeene Vergadering der Hollandsche Maatschappij (2 I Mei I777) een oeconomischen tak dier Maatschappij te stichten, die ook in 
onze Oost-Indische koloniën zou moeten werken. Met dat doel werden tot Directeuren der Maatschappij gekozen de GouverneurGeneraal Van Riemsdijk, de Directeur-Generaal Reinier de Klerk en diens schoonzoon Mr. Jacobls Cornelis Matthaels RadelMACHER, aan wie een voorloopig programma werd verzonden met verzoek, tot deze stichting te willen medewerken. RaDERMACHER had reeds lang met eenige vrienden plannen beraamd, om „,de fraaye letteren en kundigheden te Batavia en in de overige Oostersche volksplantingen op den troon te vestigen". „Men begreep (en dus begrijpen het ook vele uitmuntende mannen in het vaderland), dat, indien er in deze Oostersche gewesten immer eenige voortplanting van het Evangelie plaats kan hebben, de smaak voor kunsten en wetenschappen daartoe aanleiding moet geven, gelijk, voor twee eeuwen, de hervorming der letteren die der godsdienst voorafging, even als de blozende dageraad het opkomen van de zon". Deze woorden, aan het voorbericht, dat het eerste deel der Verhandelingen van het Bataviaasch Genootschap vooraf ging, ontleend, toonen ten duidelijkste, hoe het doel eigenlijk was bevordering van het Evangelie en van de volkswelvaart, en de beoefening van wetenschappen en kunsten slechts middel.

J. C. M. RAderincher stamde uit een Zeeuwsch geslacht, dat, oorspronkelijk uit Aken en in 1599 naar Middelburg gekomen, reeds sedert een eeuw bewindhebbers aan de O.-I.-C. geschonken had. Zoo kwam ook JACoBus, de op 30 Maart I74I geboren tweede zoon van den Thesaurier-Generaal der vorstelijke domeinen Johan Corvelis Rader.iacher, nadat hij op veertienjarigen leeftijd wees geworden was, door bemiddeling van zijn oom SAucEL, bij de O.-I.C. in betrekking en vertrok als jongen van zestien jaar met den rang van Onderkoopman naar den Oost. Een voorspoedige loopbaan wachtte hem hier; na vier jaar ( I $76 \mathbf{I}$ ) werd hij tot Koopman bevorderd, en reeds 
DE ACHTTIENDE EEUW.

het daaropvolgende jaar tot Opperkoopman, een voor een 2 I-jarigen man niet geringe waardigheid. $\mathrm{Na}$ een zesjarig verblijf in de tropen werd hij ,na Nederland verlost", waar hij zijn tijd o. a. gebruikte, om te Harderwijk tot meester in de rechten te promoveeren. In het begin van 1767 naar Indië teruggekeerd, werd hij in I768 Schepen van Batavia en een half jaar later Baljuw en Kerkmeester. Dit ambt bekleedde hij een achttal jaren, totdat hij Io October I775 door Heeren Bewindhebbers tot Raad-extraordinair benoemd werd.

Gedurende zijn verblijf in Europa was RADERMACHER sterk onder den invloed gekomen van de nieuwe beweging in wetenschappelijke kringen; geen wonder, dat hij het plan opvatte, na zijn terugkeer naar Indië, ook daar in het belang der algemeene welvaart de herleving van kunsten en wetenschappen te bevorderen, ook daar een centrum van wetenschapsbeoefenaars te stichten. Zoo was hem het programma der Hollandsche Maatschappij, waarin de stichting van een oeconomischen tak, die ook in Indië voedsel zou moeten vinden, aangekondigd werd, wel in hooge mate welkom, maar evenzeer waren zijn plannen meeromvattend, op veel ruimer leest geschoeid; hij wilde een volkomen zelfstandig genootschap. De tegenwerking, die hij reeds eenigen tijd van de zijde der O.-I.-C. had ondervonden, was door het optreden van zijn schoonvader REINIER DE KLeRK als Gouverneur-Generaal gebroken. Als resultaat van RADERMachers pogen, daarin gesteund door zijn vrienden Mr. W. van Hogendorp en den predikant J. Hoovman, werd het Bataviaasch Genootschap van Kunsten en Wetenschappen opgericht, aldus het oudste wetenschappelijk genootschap, door een koloniseerende mogendheid in haar bezittingen gesticht. Den $24^{\text {en }}$ April 1778 gaf Zijne HoogEdelheid de GouverneurGeneraal DE KLerK zijn ingenomenheid met de plannen te kennen, en aanvaardde hij het Opper-directeurschap. Op I Juni 
1778 vergadercie het bestuur voor de eerste maal, samengesteld uit: Raderiacier als Voorzittend directeur, de dirigeerende leden Mr. J. de Meyer, J. van Iperen, J. Hoovian, S. Bartlo, Mr. W. van Hogendorl', H. N. Laclé, J. van dek Steege, Mr. E. Blomhert en Mr. P. Gevers, en den secretaris F. vox Wermb ${ }^{\mathrm{r}}$ ). Zoo was door RADERMACHERS invloed en werkkracht in Indiè een instelling tot stand gekomen, bestemd eens een middelpunt van wetenschappelijk leven te worden, met perioder van bloei en van verval, van opgewekte werklust en van verslappende lusteloosheid. Reeds bij resolutie van 30 Juni 1778 werd door de Hooge Regeering ,goedgevonden en verstaan de Bestuurders van dit Genootschap te authoriseeren tot het aangaan van zoodanige Societeit, onder de zinspreuk: Ten nutte van het Gemeen, en hen teffens te accordeeren van hun programma en andere papieren in Comps. Boekdrukkery te laaten drukken, mits het papier dat daartoe zal worden gebruikt uitkoops in Compagnies Kassa betalende" "2).

Wèl is de houding der Compagnie ten opzichte van wetenschappelijk onderzoek veranderd door den invloed van DE KLERK; vóór zijn optreden zou het stichten van een dergelijk genootschap niet ,zo een edel en lofwaardig voornemen" genoemd zijn. Weliswaar werden aan de Heeren Directeuren en Leden van het Genootschap "Conditien en verpligtingen, aan de welke zy genegen zyn zig eensgezind vrywillig te onderwerpen", op-

1) Zie P. BreEker, 1853. Overzigt der geschiedenis van het Bataviaasch Genootschap van Kunsten en Wetenschappen van $1778-1 S_{53}$. (Verhand. Bataviaasch Gen. v. K. en W. XXV. 1853. p. I-24).

P. J. Veth, I $\$ 57$. Het Bataviaasch Genootschap van Kunsten en Wetenschappen. 6 stukken. (Gids. I857. Nieuwe Serie ro Jrgng. I. p. 217-237-249; $35^{6}-372 ; 687-704$ en II. p. $\left.375-398-422\right)$.

2) Zie H. 'T. Ler Kinderen, 1878. Het Bataviaasch Genootschap van Kunsten en Wetenschappen gedurende de eerste eeuw van zijn bestaan. $17 \gamma S-1 S ; S$. Gedenkboek. Batavia. 1878. Bijlage B. p. XI. 
gelegd, maar deze voorwaarden waren niet drukkend; natuurlijk mocht het Genootschap geen handelingen verrichten in strijd met de belangen der O.-I.-C.; de vijfde paragraaf der Statuten vermeldt deze, eenigszins beperkende, bepalingen: „Het Genootschap sluit geheel en al buiten den kring zijner onderzoekingen alle berichten, die de Oost-Indische Compagnie eenigszins zouden mogen aangaan; maar zal daar tegen alle Kunsten en Wetenschappen poogen te bevorderen".

Gedurende den eersten tijd was het genootschapsleven krachtig; onder RADERMACHERs leiding en met medewerking van den secretaris VoN WuRMB begon het zijn werkzaamheden, werden talrijke prijsvragen uitgeschreven, die vooral betrekking hadden op den landbouw, en verschenen de eerste deelen der Verhandelingen ${ }^{\mathrm{T}}$, waarin steeds de bekroonde antwoorden opgenomen werden en die voor het overige gevuld werden met wetenschappelijke bijdragen, door de leden bewerkt. Zooals het meestal in dergelijke genootschappen gaat, vormde ook hier zich een kleine kern van ernstigwillende mannen, waaromheen een groot aantal mannen, wier medewerking alleen in geldelijken zin eenig nut had. RADERMACHER zelf leverde voor de Verhandelingen een twaalftal artikelen, waaronder bijv. een „Beschrijving van het eiland Borneo, voor zoo verre het tot nu toe bekend is”, een "Bericht wegens de zware aardbeving van den 22 sten January anno I780", voorts beschrijvingen van het Koninkrijk Jacatra en de stad Batavia, van Sumatra, van Japan, van Celebes, Flores, Soembawa, Lombok en Bali. Na in I78I tot Raad-ordinair benoemd te zijn, keerde RADERMACHER in

I) Verhandelingen van het Bataviaasch Genootschap van Kunsten en Wetenschappen. Deel I. Batavia-'s Hage. I 779. $8^{\circ}$ en $4^{\circ}$.

Idem. $\mathrm{I}^{\mathrm{e}}-3^{\mathrm{e}}$ Deel. Herdruk. Rotterdam-Amsterdam. I78r, I784, I787. $8^{\circ}$.

Idem. $\mathrm{r}^{\mathrm{e}}-6^{\mathrm{e}}, 8^{\mathrm{e}}-9^{\mathrm{e}}$ Deel, $2^{\mathrm{e}}$ Druk. Batavia. $\mathrm{r} 820-\mathrm{r} 827.8^{\circ}$.

Idem. $\mathrm{I}^{\mathrm{e}}-2^{\mathrm{e}}$ Deel. $3^{\mathrm{e}}$ Druk. Batavia. I825-1826. $8^{\circ}$. 
${ }_{17} S_{3}$ wegens gezondheidsredenen naar het Vaderland terug, op welken tocht hij met zijn vrouw bij een aan boord der "Java" (waarop hij als vice-admiraal der retourvloot reisde) uitgebroken Chineezen-oproer om het leven kwam. Het Bataviaasch Genootschap verloor in hem veel; hij was de ziel en stichter ervan; door zijn krachtig voorbeeld scheen het een groote toekomst tegemoet te gaan. Het bestuur kwam na zijn vertrek in handen van Adrianan Moens, Directeur-Generaal van Nederlandsch-Indië, die hem in het voorzitterschap opvolgde. Behalve de moreele leiding, dankte het genootschap aan RADERMACHER nog het bezit van een eigen lokaal, van een belangrijke boekenverzameling en van een groote collectie natuurhistorische en ethnografische voorwerpen.

Den meesten steun ontving Radermacher van de leden Van Hogendorp, Van Iperen, Hoovman, v. D. Steege, Titsingh en Von Wurmb. Door hun arbeid konden de eerste deelen der Verhandelingen geregeld verschijnen; weliswaar begon reeds in 1782 , nadat 3 deelen het licht gezien hadden, een vermindering van werkzaamheden merkbaar te worden, maar dit verschijnsel moest grootendeels worden toegeschreven aan den Engelschen oorlog en de daaruit voortkomende moeilijkheden. Zoo verscheen het vierde deel eerst in 1786 , het vijfde in I790, het zesde in I792, maar daarna is dan ook de eerste bloeiperiode van het Genootschap geëindigd.

De belangrijkste verhandelingen met natuurwetenschappelijke onderwerpen in deze deelen zijn van de hand van den secretaris Fred. von Wurmb, aan wien o. a. verschillende „Bijdragen tot de Natuurlijke Historie” en een overzicht van "De orde der palmboomen" te danken zijn, en van den Spaanschen natuuronderzoeker Noronia, die na bestudeering der Flora van Manilla naar Java kwam, aldaar van den G.-G. Alting en het Genootschap veel steun ontving, en dan ook in de Verhandelingen 
DE ACHTTIENDE EEUW.

mededeelingen deed verschijnen over verschillende Javaansche planten (o. a. Altingia excelsa), met een catalogus, waarin Latijnsche en Maleische namen naast elkaar vermeld werden. $\mathrm{Na}$ Radermachers vertrek was Von Wurmi de ziel van het Genootschap; hij verzorgde bibliotheek en kabinet, begon den aanleg van een plantentuin op een stukje grond aan de Amanusgracht gelegen, door het dirigeerend lid S. BARTLO daartoe aan het Genootschap ten geschenke gegeven, en deed zoodoende pogingen aan Indië opnieuw, na den tuin van den G.-G. CAmpurys op het eiland Edam, een plantentuin te schenken. Wat er na Von WUrubs dood, die voor het Genootschap een zwaar verlies was $(5$ Dec. I $78 \mathrm{I})$ van den plantentuin geworden is, is onbekend. Later (I79I) is opnieuw getracht een botanischen tuin te stichten, thans op een door het dirigeerend lid F. Schocwman afgestaan, aan de Molenvliet gelegen terrein, maar ook deze tuin is zonder een spoor na te laten, verdwenen ${ }^{\mathrm{I}}$ ).

Langzamerhand verdwijnt de werklust van het Genootschap; ongeveer 1792 begint een twintigjarig tijdperk van diepe rust. Het eenige belangrijke, wat in deze jaren in onze tropen verricht wordt, is het onderzoek van LeschexatlT DE LA Totr, die op een wereldreis (1800-1804) ook Java, Madoera en Timor bezocht en daar mooie floristische studies maakte. Zijn verzamelingen, opgenomen in het Muséum d'Histoire Naturelle te Parijs, stelden later anderen in staat een aantal nieuwe soorten van Java te beschrijven en een Flora van Timor samen te stellen.

In Europa werd intusschen ook met ijver aan de bewerking der tropische flora gearbeid: Nicolaas Lalrens Burian, de zoon van Johannes, den Kruidboekuitgever, begon in 1768 zijn

1) Zie M. Greshoff, ISgI. Naar aanleiding van het overlijden van G. J. FiLET. (Teysmannia. II. p. 170-175). p. 173-175.

P. H. v. D. KEMP, 19I4. De stichting van den botanischen tuin te Buitenzorg. (Nieuwe Gids. 1914. p. 388-410). p. 39r. 
„Flora Indica" ${ }^{2}$ ) in het licht te geven, gebaseerd op de verzamelingen van reizigers, als bijv. Hermaxv (zie blz. i2) en vooral belangrijk, omdat zijn werk het eerste was, waarin de Linneaansche nomenclatuur werd toegepast, zoodat het dientengevolge tal van nog tegenwoordig geldende namen bevat. De meestal verwaarloosde plantendeelen, vruchten en zaden, waren het onderwerp van GAERTNERS beroemd werk ${ }^{2}$ ), waarin ook van een aantal tropische planten uitvoerige vrucht- en zaadbeschrijvingen gegeven werden.

De nieuwe eeuw begon onder zeer ongunstige omstandigheden; de banden waarin het Genootschap door de officiëele waardigheden der bestuurders gekneld was, waren op den duur belemmerend voor een vrije ontwikkeling; een ingrijpende hervorming was dringrend noodzakelijk. Wij zien Ross, den voorzitter, alle krachten inspannen om aan den druk der omstandigheden weerstand te bieden en opnieuw leven te brengen in den toestand van verdooving, maar tevergeefs. De Nederlandsche ondernemingsgeest ontbrak; iedere poging tot bezieling stuitte onverbiddelijk af op het gebrek aan levenskracht, waarvan de gansche Koloniaal-Nederlandsche maatschappij in die dagen zoo droevig getuigenis aflegde. Ook Ross' hervormingen, die in het midden van 1802 hun beslag kregen, werkten niets uit; het Genootschap bleef slapen.

Slechts een der leden voelde zich geroepen de wetenschap te dienen: de Engelschman Thomas Horsfield

Horsfield, die eerst Noord-Amerika bereisd had, kwam in I 802 naar Java, om daar zijn botanische en mineralogische

×) N. L. Burman, r 768 . Flora indica Nicolai Laurentii Burmanni: Cui accedit series zoophytorum indicorum, nec non Prodromus Florae Capensis. Lugduni Batavorum, C. Hofk; Amstelaedami, J. Schrelder. I768. $4^{\circ}$.

2) J. Gaertner, i $788-1791$. De liructibus et Seminibus Plantarum. (Stutt gart-Tübingen, $1788-1791$ ). 
DE ACHTTIENDE EEUW.

onderzoekingen voort te zetten; met ondersteuning van Genootschap en Regeering, die hem een vrije woning, een studielokaal, de hulp van een teekenaar der Semarangsche marineschool en een vrij hoog honorarium toezegde, legde hij zich vooral toe op onderzoek der geneeskrachtige Javaansche planten. Zoo waren Batavia's omstreken, Buitenzorg, Preanger, Cheribon en Java's noordkust achtereenvolgens het terrein zijner werkzaamheden. Horsfield kende geen zelfbeperking; hij gaf zich geheel aan zijn werk. Hoe verder zijn werk vorderde, des te grooter bleek hem het braakliggende terrein, dat in steeds ruimer omvang voor zijn oogen zichtbaar werd; ten slotte vatte hij het plan op, een uitvoerige Flora Javana te bewerken, met welk doel hij zich te Soerakarta vestigde. Botanisch onderzoek ${ }^{i}$ ) vereenigde hij met geologisch-mineralogische en zoölogische studiën, maar van al wat hij vond en van al wat hij aan het Genootschap meedeelde, kon voorloopig niets gedrukt worden uit gebrek aan... drukletters. Zijn onderzoekingen op dierkundig terrein vatte hij later samen in een groot werk ${ }^{2}$ ), terwijl zijn insectenverzamelingen het materiaal leverden voor een werk van W. Sharpe MacLeay ${ }^{3}$ ).

Nieuw leven kwam er na de overgave van onze koloniën aan de Engelschen; de Luitenant-Generaal Sir Sta.Mford Raffles was een man vol liefde voor de wetenschap: terecht zag hij

^) Als resultaat hiervan verscheen T. HoRsfieLd, 1838-i852. Plantae Javanicae rariores, descriptae .... quas in insula Java, annis $1802-1818$, legit et investigavit - - E siccis descriptiones et characteres plurimarum elaboravit J. J. Bennet; observationes structuram et affinitates praesertim respicientes passim adjecit R. BRown. Londini, $1838-1852.4^{\circ}$.

2) T. Horsfield, I824. Zoological researches in Java and the neighbouring islandis. London, $1824 \cdot 4^{\circ}$.

3) IV. Sharpe Macleay, I825. Annulosa javanica, or an attempt to illustrate the natural affinities and analogies of the Insects, collected by THOmas HorsfiELD. London, 1825 . 
in, hoe grooten invloed ten goede het Bataviaasch Genootschap kon uitoefenen, en hoe gering die invloed was in den tijd waarin hij het bestuur aanvaardde (I8II). RAFFLES had in Bengalen de werking van de "Asiatic Society of Calcutta" gezien, een instelling, vijf jaar jonger dan het Genootschap, maar met veel meer levenskracht. Onmiddellijk pakt RAFFLES de zaak aan: in Batavia moest meer wetenschappelijk leven komen en een tak van de Asiatic Society te stichten, leek nutteloos; dus besloot hij het Bataviaasch Genootschap te hervormen. Op alle manieren steunde hij het Genootschap, en wekte de leden op tot werken; de wetenschappelijke Engelschen, die zich na de overgave op Java gevestigd hadden, waren hem als een staf, die hem bij de uitvoering van zijn grootsche plannen moest terzijde staan. Het Genootschap bood hem het voorzitterschap aan; de Gouverneur-Generaal Lord Minto werd Protector. "Spoedig ontwaakte dan ook", zegt VAN HoËvelL ${ }^{x}$ ), ,de ingesluimerde geest van werkzaamheid der voortreffelijke inrigting met jeugdige kracht. Hij moedigde anderen niet alleen met woorden aan, maar gaf zelf het voorbeeld, en werd de voorganger in de baan der letteroefeningen. Als Voorzitter des Genootschaps hield hij zelf in de vergaderingen verhandelingen en redevoeringen, die van zijne uitstekende bekwaamheid getuigden. Daarvan was tot dusverre nog geen voorbeeld geweest, dat het hoofd des bestuurs het niet beneden zich achtte, in eigen persoon mededeelingen te doen. Onbegrijpelijk was dan ook de invloed, dien dit op de andere leden des Genootschaps uitoefende". Daarin lag Raffles' groote bezielingskracht; hij was niet alleen voorzitter, maar ook werkend lid. RAFFLES was een man van groote organisatorische gaven; weliswaar liggen zijn studiën meer op geschiedkundig

ז) W. R. van HoËvell, I839. p. 67. 
DE ACHTTIENDE EEUW.

en geografisch terrein, dan op dat der natuurwetenschappen: zijn "History of Java" is hiervan een monument, een getuige voor de opgewekte kracht waarmee RAFrLes zich aan zijn wetenschap gaf. Dat echter ook de tropische natuur zijn aandacht bezighield, blijkt uit een door hem gepubliceerde lijst van zoölogische voorwerpen, op Sumatra verzameld ${ }^{x}$ ). Bovendien had hij gedurende zijn verblijf in de tropen verzamelingen van natuurvoorwerpen en levende dieren bijeengebracht, welke verzamelingen met al zijn geschriften en teekeningen verloren gingen doordat op het schip, dat hem in Februari 1824 van Benkoelen huiswaarts brengen zou, brand uitbrak. RAFFLEs zelf slaagde er ternauwernood in, zich in veiligheid te brengen.

De Engelsche overheersching had dus op Java voor het wetenschappelijk onderzoek gunstige gevolgen gehad: er was nieuw leven gebracht, de weg voor voortzetting na de teruggave was den Nederlanders gemakkelijk gemaakt. Maar toch kunnen wij, met alle waardeering voor RAFFLEs en zijn Engelsche medewerkers, niet nalaten hier te wijzen op het vreemde en volkomen onjuiste der bewering van HeEREN $^{2}$ ), die van het Engelsche tusschenbestuur meende te moeten getuigen: „Während ihres fünfjährigen Besitzes ward eine so kluge und so milde Verwaltung eingeführt, dasz es seit der Rückgabe Eingebornen und Europäern schwer zu werden scheint, sich wieder an Holländische Herrschaft zu gewöhnen. Auch hat jener kurze Besitz der Britten ein helleres Licht über die merkwürdige Insel verbreitet, als die zweihundertjährige Herrschaft der Holländer". Een dergelijke lofprijzing der Engelschen met volkomen negatie

I) S. RAFFLES, IS22. Descriptive catalogue of a zoölogical collection, made in account of the Hon. East India Company in the island of Sumatra and its vicinity. (Transactions Linnean Society. XIII. 1822).

2) A. H. L. Heeren, 1830. Handbuch der Geschichte des Europäischen

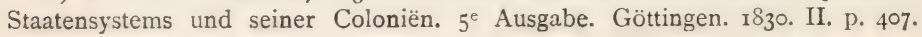


van al het goede door onze Compagnies-ambtenaren, door VAN REeDE en Rumphius tot stand gebracht, is toch wel wat heel ver bezijden de waarheid.

Arm aan resultaat, was de achttiende eeuw een overgangsperiode naar een nieuw tijdvak, waarin voor ons Indië betere tijden zouden aanbreken; het verlichte bestuur van Willem I, de ruime opvattingen van $\mathrm{Zijn}$ Algemeenen Secretaris FALCK, en de groote bekwaamheid der drie Commissarissen-Generaal v. D. Capellen, Elout en Buyskes waren de drie factoren, die Indië's bloei zouden bewerken; de man, wien wij de herleving van het natuuronderzoek in de eerste plaats danken, was C. G. C. Reinivardt. 


\section{HOOFDSTUK IV.}

\section{De Natuurkundige Commissie.}

\section{(I816-I850). \\ Opkomst van 's Lands Plantentuin.}

\section{Het daghet in den Oosten.}

Met vol recht mogen we dit zoo vaak gebruikte en zoo vaak misbruikte woord toepassen op den eersten tijd van Neêrlands herstel; voor Indië begint een periode van nieuwen opbloei, van verjongde levenskracht. De vooruitziende geest van FALCK, den Algemeenen Secretaris van den Souvereinen Vorst, gevoelde hoezeer het onderzoek onzer herkregen koloniën van belang was, hoe groot de verantwoordelijkheid onzer natie was bij het aanvaarden van het bestuur dezer bezittingen; hij was doordrongen van de gedachte, dat deze gewesten niet alleen finantieel voordeel moesten opleveren, maar dat wij, als koloniseerende mogendheid, ook moreele verplichtingen te hunnen opzichte hebben. „Ons moet niet langer”, zoo schrijft hij aan REINWARDT, „de verdienste ontgaan van onze koloniën even grondig te kennen als onze naburen de hunne. Java alleen zal in de rijken der Natuur tot de belangrijkste waarnemingen en ontdekkingen aanleiding geven". 



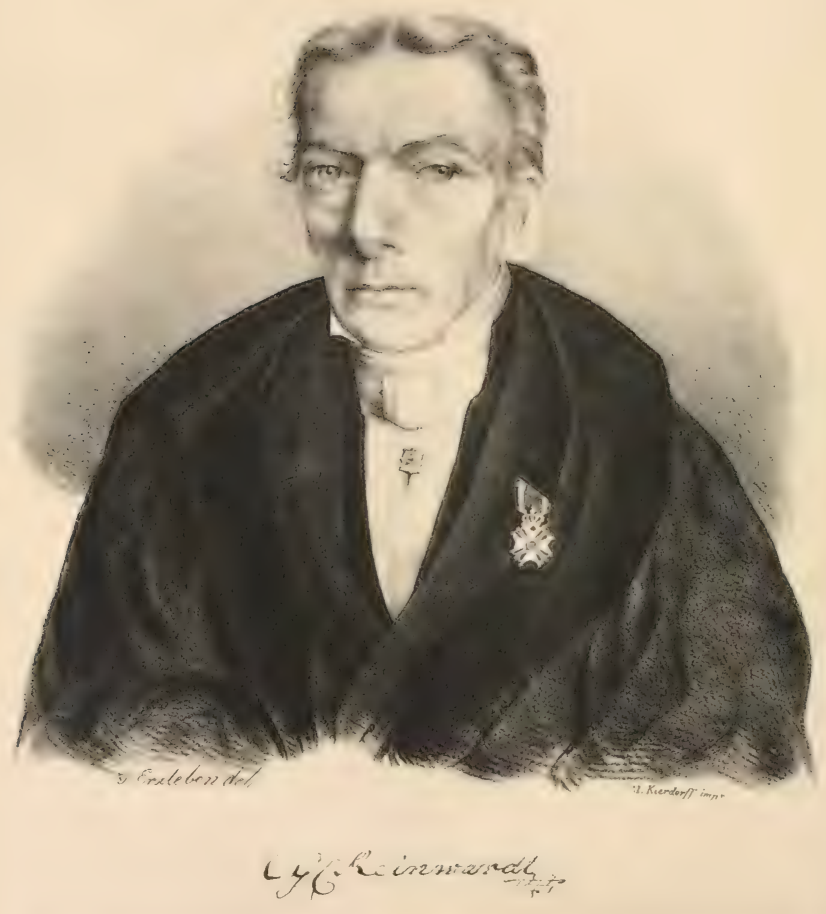

C. G. C. REINWARDT. 
Het was op voorstel van de drie Commissarissen-Generaal, dat FALCK aan REINwARDT deze uitnoodiging zond: te willen aanvaarden het nieuwe ambt van ,Directeur tot de zaken van Landbouw, Kunsten en Wetenschappen op Java en de naburige eilanden" en het was een gelukkige gedachte, juist een man als REINiward voor deze waardigheid te kiezen.

Caspar Georg Carl Reinwardt ${ }^{5}$ ) was in 1787 als veertienjarige jongen uit zijn geboortestadje Lüttringhausen (Pruisen) naar Amsterdam gekomen, waar zijn oudste broeder het beheer eener apotheek op zich genomen had. CASPAR wordt als apothekersleerling in de geheimen der kruidkunde ingewijd; beide broeders toonen een uitnemenden wetenschappelijken aanleg; terwijl broers liefhebberij vooral scheikundig onderzoek was, koos CAspar de plantkunde als zijn hoofdvak. Reeds spoedig trok dit broederpaar de aandacht der Amsterdamsche geleerdenwereld, waarvan vele uitmuntende vertegenwoordigers hun met raad en daad terzijde stonden; in het bijzonder de jongere CASPAR schijnt algemeen gewaardeerd te worden. Terwijl hij op het punt staat, na eenigen tijd aan het Athenaeum illustre onzer hoofdstad gestudeerd te hebben, zich voor de voltooiing zijner medische studiën naar de Göttingsche Georgia Augusta te begeven, wordt hij, vooral door de krachtige aanbeveling van zijn Amsterdamschen leermeester G. VRoLIK, door de Harderwijksche Hoogeschool tot hoogleeraar beroepen, als opvolger van den overleden botanicus Schicht (I I Juni I Soo). En dit verwondert geenszins indien wij kennis nemen van de aanbevelende woorden, die Vrolik hem meegaf: „een man van buitengemeene vorderingen in schei- en kruidkunde, maar ook van een steeds werkzamen en veelomvattenden geest".

I) Zie P. J. Veth, 1884. Caspar George Carl Reinwardt. (In zijn: Ontdekkers en Onderzoekers. Zevental levensschetsen. Leiden, 1884. p. 95-149). 
Voordat hij aldaar het hooge ambt aanvaardde, schonk de Harderwijksche Senaat hem, den 27-jarigen, nog het doctoraat in de geneeskunde en de natuurlijke wijsbegeerte honoris causa. Het is, alsof REINWARDT voorgevoeld heeft, wat nog eens zijn levenstaak zou worden: zijn inaugureele rede ,over de geestdrift waarmede de beoefenaars der Natuurlijke Historie, en inzonderheid der Kruidkunde, voor hunne studiën bezield zijn", stelde hij onder een motto, waarin we van zijn eigen toekomst een groot deel weerspiegeld vinden, de woorden var Fonteneile: "De plantkunde is geene stilzittende, trage wetenschap, die men, zooals de wiskunde en de geschiedenis, kan verkrijgen in de schaduw der studeercel. $Z_{i j}$ vordert, dat men bosschen en bergen doorkruise, steile rotsen beklautere, zich wage aan den rand der afgronden". Zeven jaar lang bekleedde REINwARIT op verdienstelijke wijze het hoogleeraarsambt, weliswaar nog meer opnemend dan voortbrengend werker, totdat Koning LoDEwiJk hem tijdens Zijn bezoek aan de Harderwijksche Hoogeschool, aanzocht voor de betrekking van Directeur van een aan te leggen plantentuin met diergaarde en natuurhistorisch museum. REINIVARDT zal dit verzoek wel niet van ganscher harte verheugd hebben; het ambt van Directeur eener vorstelijke menagerie was niet bijzonder aantrekkelijk, terwijl ook de ijdelheid en wispelturigheid Zijner Majesteit voor $\mathrm{Zijn}$ ondergeschikten onaangename eigenschappen waren. Toch moest REINwARDT aan dit vorstelijk verzoek wel gehoor geven, en dus zien we hem in 1808 eerst naar Soestdijk, daarna naar Haarlem vertrekken, en nog later naar Amsterdam, telkens wanneer een koninklijke gril de residentie geliefde te verplaatsen. Koning Lodewijk scheen met zijn geleerden dienstknecht wèl ingenomen te zijn; Zijn goedhartigheid zorgde, kort voor Zijn aftreden, dat REINWARDT in een ,,veilige haven” kwam: den eersten Juli I 810 ontvangt hij zijn benoeming tot Hoog- 
leeraar in de plantkunde aan het Amsterdamsche Athenaeum en tot buitengewoon Hoogleeraar in de scheikunde.

Zoo was de levensloop geweest van den man, aan wien in 18I 5 (I 5 Januari) de organisatie van Onderwijs, Geneeskundigen dienst, Landbouw, Nijverheid en Wetenschappelijk Onderzoek in Indië opgedragen werd, een taak, te veelomvattend voor de werkkracht van één persoon, ook voor een ,,steeds werkzamen geest", als die van Reinwardt.

Bevordering van natuuronderzoek was wel de meest aantrekkelijke taak voor den geleerde: weliswaar vermeldt het tweede artikel van het Koninklijk Besluit als zijn plicht, om „onze Commissarissen-Generaal, alsmede Gouverneur-Generaal in rade, te dienen van consideratien en advies over alle poincten en questien over welke zy respectievelyk goed zullen vinden hem te raadplegen speciaal voor zooveel die betrekking hebben tot de cultuur van den grond, de houtbosschen daaronder begrepen; tot de maatregelen ten nutte der openbare gezondheid, tot de opvoeding der jeugd, enz.", en schijnt dus zijn opdracht in de eerste plaats op de practijk gericht, maar daarnaast vinden we een meer ideëele opvatting van het doel zijner werkkring in artikel I 4 van hetzelfde Kon. Besl.: „Hoofdzakelijk echter, en om zich ter vervulling der plichten bij art. 2 omschreven des te beter te bekwamen, zal hij den aard van den grond en deszelfs voortbrengselen nauwkeurig gadeslaan, delfstoffen opsporen en nuttige waarnemingen doen omtrent het dierenrijk. Van alle merkwaardigheden zal hij trachten zich een of meerdere exemplaren te verschaffen, teneinde het Kabinet van Natuurlijke Historie te Amsterdam hoe langer hoe meer te verrijken". Met het doel, hem ,in de rigtige uitvoering van zijn last" terzijde te staan, werden hem ter beschikking gesteld de teekenaar A. J. Bik en de Harderwijksche hortulanus W. Kent. Van hoe groot belang ReivwaRdTs zending door de geleerde wereld be 
schouwd werd, blijkt uit de aan het Kon. Besl. van I 5 Januari i 8 I 5 als Bijlage toegevoegde lijst van ongeveer honderd vragen, op zeer verschillende onderwerpen betrekking hebbend ${ }^{\mathrm{x}}$ ).

Maar REINWARDT was er de man niet naar, te wachten tot Heeren Commissarissen-Generaal hem om "consideratien en advies" vroegen; uit eigen beweging gaf hij aan de Hooge Regeering een aantal plannen ${ }^{2}$ ) ter overdenking op alle hem toevertrouwde gebieden; wel een der eerste en in de gevolgen het meest verstrekkende voorstel was dat, hetwelk hij den I 5 en April I 8 I 7 tot het besturend driemanschap richtte: „, Ie om aan mij authorisatie te verleenen tot het doen aanleggen van eenen kruidtuin, geschikt ter aankweking van gewassen en tot het doen van landbouwkundige proeven, en zulks op een gedeelte der tuingronden op Buitenzorg, tot dat einde door Zijne Excellentie den Gouverneur-Generaal aangeboden, en $2^{\mathrm{e}}$ tot Hortulanus van den Plantentuin op Buitenzorg te benoemen en aan te stellen JAMEs HoOPER, op een maandelijksch traktement van een honderd en vijftig gulden enz." Het was REINWARDTS bedoeling, aan den hortulanus Hooper, die reeds een tocht naar China medegemaakt had en zes jaar lang aan den beroemden plantentuin van Kew was werkzaam geweest, het dagelijksch beheer van den Buitenzorgschen Hortus op te dragen, om dan den Harderwijkschen hortulanus KENT te kunnen medenemen op de onderzoekingstochten, die hij in het vooruitzicht had.

De bestemming van den nu gestichten ,'s Lands Plantentuin", de inrichting, die wij vanaf het jaar I 8 I 7 als het middelpunt van het wetenschappelijk botanisch onderzoek van Java

r) Zie W. H. de Vriese, i 858 (en J. Pijnappel). Reis naar het Oostelijke gedeelte van den Indischen Archipel in het jaar i82 I door C. G. C. ReinwardT. (Amsterdam, 1858). p. 37-48.

2) Zie P. H. v. D. KeMP, I9r4. p. II-r3. 
en de Buitenbezittingen kunnen beschouwen, was tweeërlei; in de eerste plaats zal ,zulk eene plaats niet alleen kunnen dienen ter aankweking van vele gewassen, die in onze kolonie inlandsch zijn, maar men zal aldaar ook voorloopig de kultuur van vele andere nuttige gewassen kunnen beproeven", en bovendien ,zal zij al nader geschikt zijn tot een kweekschool en verzamelplaats van planten, welke van hier voor onderscheidene kruid. tuinen en soortgelijke stichtingen in verschillende gewesten en in Nederland verlangd worden". De bestudeering van Indische planten, die in onherbergzame streken groeien, om dus van merkwaardige gewassen een meer nauwkeurige kennis te verkrijgen, lag dan ook volkomen in de lijn van ReINWARDTs ruime opvattingen.

$\mathrm{Na}$ het overwinnen van talrijke moeilijkheden, vooral door het gebrek aan werkvolk veroorzaakt, kon den iSden Mei i I $_{7}$, dus nauwelijks een maand, nadat REINwARDT zijn voorstel bij Commissarissen-Generaal had ingediend en door deze bestuurderen hierop een beslissing was genomen, een aanvang met de werkzaamheden gemaakt worden. Die datum, door Treub ${ }^{\mathrm{x}}$ ) terecht ,de geboortedag van 's Lands Plantentuin" genoemd, is een keerpunt in de geschiedenis van het koloniaal-wetenschappelijk onderzoek. Vaak, zoo bijv. door DE Vriese ${ }^{2}$ ) en VETI ${ }^{3}$ ) wordt de wetenschappelijke beteekenis van 's Lands Plantentuin onderschat; Vetr's woorden: ,niet enkel, en zelfs niet in de eerste plaats, tot bevordering van de wetenschappelijke kennis der plantenwereld, maar vooral met het doel om het nuttig gebruik op te sporen dat van vele planten kan gemaakt worden, en om zich de gelegenheid te openen tot

I) M. Treub, IS92. Korte Geschiedenis van 's Lands Plantentuin. (In: 's Lands Plantentuin te Buitenzorg. I8 Mei I8I7-I8 Mei is92. Batavia. p. I-58). p. 7 .

2) W. H. De Vriese, 1858 (en J. Pijnappel). p. 58.

3) P. J. Veth, 1884. p. 117. 
DE NATUURKUNDIGE COMMISSIE.

allerlei proeven in het belang der verschillende takken van industrie in Indië en in het Moederland", zijn dan ook een gedeeltelijke miskenning van REINwARDTs ruim-opgezette plannen en worden terecht tegengesproken door TRELB, die met liefde gebruik gemaakt heeft van de gelegenheid, hem door zijn ambt van directeur van den Plantentuin geboden, uit de archieven dier instelling een geschiedkundigen ontwikkelingsgang samen te stellen en wien wij dan ook een tweetal historische overzichten danken; één, een uitvoerige "Geschiedenis van 's Lands Plantentuin te Buitenzorg" "), waarvan helaas slechts het eerste gedeelte verschenen is, hetwelk het tijdvak $1817-18+4$ behandelt en een andere „Korte Geschiedenis van 's Lands Plantentuin", versierd met de portretten der leiders (REINWARDT, Blume, Hasskarl, Binnendijk, Scheffer) en een inleiding vormend tot het gedenkboek ter gelegenheid van het 75-jarig bestaan uitgegeven ${ }^{2}$ ). Nadrukkelijk zegt Treub ${ }^{3}$ ): „Uit al het aangehaalde blijkt, dat de meening, als zoude te Buitenzorg oorspronkelijk een proeftuin zijn gesticht, uit welken zich eerst veel later een botanische tuin ontwikkeld zou hebben, door de geschiedenis geheel wordt weersproken. Een botanische tuin was het, tot welks oprichting op Java den I 5 den April I8I 7 werd besloten, eene wetenschappelijke instelling dus, wier groote praktische beteekenis van den aanvang af werd voorzien en voorbereid". Zoolang ReinwardT in Indië bleef, berustte bij hem het hoogste beheer van 's Lands Plantentuin; hij was echter uit den aard zijner werkkring heel weinig te Buitenzorg, zoodat Hooper dan ook de dagelijksche leiding in handen had. De talrijke reizen, door REINWARDT, vergezeld van KENT, gedaan,

r) M. Treub, I8S9. Geschiedenis van 's Lands Plantentuin te Buitenzorg. I. Van 1817 tot 1844 . (Meded. 's Lands Plantentuin. VI. r889. 79 pp.).

2) Zie M. Treub, 1892 .

3) M. Treub, 1892. p. 5 . 
stelden hem in staat steeds meer materiaal voor den Plantentuin bijeen te brengen, planten en zaden naar Buitenzorg te verzenden, waar ze dan door Hooper's zorgen een plaats in den tuin vonden. Maar niet alleen de flora der bezochte streken wekte REINWARDT's aandacht; zijn veelomvattende geest hield zich bezig met het onderzoeken en verzamelen van natuurvoorwerpen in den ruimsten zin; een in Juli 1817 aangevangen reis der CommissarissenGeneraal v. D. Cafellen en Elout, door Reinwardt meegemaakt, welke reis zich over bijna geheel Java, van Cheribon tot Besoeki, uitstrekte, stelde hem in staat voortdurend te verzamelen, van alles, wat zijn aandacht trok, preparaten te maken, skeletten en huiden te bewaren en een groote collectie insecten bijeen te brengen. Alle op deze tochten ten behoeve der wetenschap gemaakte verzamelingen werden, met nog een belangrijke hoeveelheid schelpen en koraalgewassen uit de Molukken, een aantal mineralen en delfstoffen uit Java, China, Bengalen, verzonden met het linieschip "Amsterdam" om na aankomst in het vaderland aan verschillende musea te worden rondgedeeld. In September I8I8 volgde met de "Ida Aleida" een tweede bezending; in Februari ISI9 een derde, waaronder tal van zeldzame vogels en insecten, planten voor 's Rijks Academietuinen en teekeningen van A. J. Br, den teekenaar, die REINWARDT toegevoegd was, en een keurbende Indische kleederdrachten. Al deze verzamelingen, de resultaten van twee jaren ingespannen arbeid, van onvermoeid reizen en trekken, werden door het spel der zee vernietigd; de drie schepen werden door hevige stormen overvallen en verongelukten: het noodlot wilde wèl den onvermoeibaren REINwARDT tarten! "Zou het te verwonderen geweest zijn", zegt P. J. VETH ${ }^{1}$ ), ,zoo hij, dit wreede spel van het noodlot moede, alle verdere nasporingen opgegeven

ェ) P. J. VETH, I884. p. I29. 
DE NATUURKUNDIGE COMMISSIE.

en de handen in den schoot gelegd had?" Veeleer werkten al deze tegenslagen als krachtige prikkel; in den loop van 1819 ondernam Reinwardi nog groote tochten naar de Preangerbergen Salak en Gedeh, waar hem in 't bijzonder de groote uitgestrektheid van het nog te bewerken gebied opviel. Het schijnt, dat Neptunus voor een dergelijk onverwinbaar doorzettingsvermogen eerbied koesterde; van nu af aan eischte hij geen enkel van REINwardT's zendingen meer als slachtoffer zijner zeeën op.

Intusschen was REINwARDT's tijd, bestemd voor zijn verblijf in Indië, verstreken; oorspronkelijk was deze op twee jaar bepaald, hoogstens tot vier te verlengen, doch REINWARDT wilde geen onvoltooid werk achterlaten. Door medewerking van den Gouverneur-Generaal V. D. CAPELLEN, een man met een ruimen blik en een ruime schatkist (misschien beschouwde hij deze wel eens als te ruim), verkreeg hij verlenging van zijn opdracht en werd hem in Juli 1820 toegestaan tot het einde van I $82 \mathrm{I}$ in de tropen te blijven, om dan in September 1822 het ambt van Hoogleeraar te Leiden te aanvaarden, een waardigheid, waartoe hij reeds in 1819 , na den dood van den grooten BRtGMANS, geroepen was, en ondertusschen in dezen tijd een reis te maken naar Timor, de Molukken en Noord-Celebes. Van deze reis, die belangrijke resultaten opleverde, kwam hij in Maart I 822 te Buitenzorg terug, om 24 Juni d. o. v. naar het vaderland scheep te gaan.

De indruk, dien wij krijgen, als wij de resultaten van REINwARDT's werk in het belang van de natuurwetenschap overzien, is ongetwijfeld die van teleurstelling. REINwaRDT's arbeidzaamheid was, wij zeiden het reeds, onbegrijpelijk; zijn organisatorisch talent heeft aan Indië den Plantentuin geschonken; zijn altijd-werkende geest en zijn onvermoeibaar lichaam stelden hem in staat, reizen en bergbeklimmingen te ondernemen, waarvoor menig ander 
teruggedeinsd zou zijn; de liefde voor zijn vak heeft hem bij het maken van zijn verzamelingen steeds bezield en hem behoed voor neerslachtigheid, die toch zoo licht het gevolg van de aan zijn verzamelingen overkomen rampen had kunnen zijn. Maar met dat al hadden wij van een man als REINWARDT meer mogen verwachten, wat zijn professoraat betreft; wat hij na de aanvaarding van dit ambt te Leiden verricht heeft, was in hooge mate teleurstellend. Zeker, het is begrijpelijk, dat een nauwgezette persoonlijkheid als ReINivarDT ongetwijfeld was, zooals VЕTH ${ }^{\mathrm{I}}$ ) ter zijner verdediging aanvoert, ,of geen of een aitsteknd leeraar wilde zijn, en volkomen besefte, dat hij, het laatste kiezend, daaraan al zijn krachten had te wijden", maar onbegrijpelijk en onwaardig is $\mathrm{m}$. i. de verklaring, die VETH geeft: ,te meer daar hij de verbazende vorderingen had in te halen, door de natuurkundige wetenschappen, en inzonderheid door de chemie, in het tijdperk zijner zevenjarige uitlandigheid gemaakt". Op nog een eigenaardige gevolgtrekking in de overigens uitmuntende REINIFARDT-biographie van VETI ${ }^{2}$ ) wil ik hier de aandacht vestigen: VетH haalt uit Reirwardt's inaugureele rede ( 3 Mei $1823^{3}$ ), de woorden aan: ,daarom heb $\mathrm{ik} \mathrm{mij} \mathrm{in} \mathrm{Indië} \mathrm{op} \mathrm{de} \mathrm{studie} \mathrm{der} \mathrm{natuur} \mathrm{toegelegd,} \mathrm{zooveel} \mathrm{de}$ talrijke verplichtingen aan mijne veelzijdige taak verbonden, maar eenigszins veroorloofden", en vindt hierin een verklaring, ,waarom hij tot het einde van zijn lang leven de nog steeds hier en daar opduikende hoop heeft teleurgesteld, dat hij een duurzaam gedenkteeken van zijne nasporingen stichten zou'”. Voor een verschil in werkzaamheid tijdens de Indische periode

ז) P. J. Veth, I884. p. I39.

2) P. J. VETH, I884. p. I4I.

3) C. G. C. REINWARdT, I $\$ 23$ Redevoering over hetgeen het onderzoek van Indië tot uitbreiding der natuurlijke historie heeft toegebragt, vertaald door M. Siegenbeek. Amsterdam. I823. 
DE NATUURKUNDIGE COMMISSIE.

en tijdens zijn Hoogleeraarschap is de veelomvattendheid van den Indischen werkkring toch geen verontschuldiging.

Hoe dit nu zij, het is niet te ontkennen, dat het verder verloop van REINIVARDT's wetenschappelijk leven over het algemeen teleurstelling gewekt heeft, en gedeeltelijk met recht. REINWARDT, die getuige zijn inaugureele redevoeringen en zijn voordrachten, die hij in het Kon. Ned. Instituut (de tegenwoordige Kon. Acad. van Wet.) hield, over een zeer vloeiende en welgevormde stijl beschikte, heeft zich nooit de moeite gegeven, zijn talrijke in Indië opgedane ervaringen tot een boek te verwerken en niet meer gepubliceerd dan een zeer klein getal wetenschappelijke verhandelingen, terwijl toch in zijn nalatenschap een belangrijk dagboek van zijn laatste reis gevonden werd, kort na zijn overlijden (8 Maart 1854) door het Kon. Inst. voor Taal-, Land- en Volkenkunde van Ned.Indië uitgegeven $\left.{ }^{ }\right)$. Hierin vinden we, behalve een uitvoerige levensbeschrijving door DE VRIESE, nog afgedrukt een door Reinivardt gehouden voordracht $(27$ Dec. 1827 in het Kon. Inst.): „Over de natuurlijke vruchtbaarheid der Oost-Indische eilanden, en bijzonder van Java, en over de waarschijnlijke oorzaken daarvan", en voorts o. a. opgaven van al wat door REINWARDT ten behoeve der musea naar het vaderland verzonden is. Bovendien heeft DE VRIEsE gezorgd voor een eenigszins samenhangende uitgave van REINWARDT's plantenverzamelingen ${ }^{2}$ ), een grootsch opgezet, maar onvolledig gebleven werk, gewoon-

r) De uitgave van dit dagboek werd bezorgd door ReInwaRdT's leerling en opvolger W. H. DE VRIESE en den Delftschen hoogleeraar J. Pijnappel; het werk werd versierd met platen van ReINwardT's teekenaars A. J. en J. T. BIK en van den $\mathrm{I}^{\mathrm{en}}$ luitenant Q. M. J. Verhuell, wiens belangrijke insectenverzameling met REINWARDT'S derde zending verloren gegaan was. Zie p. 9o, noot $\mathrm{r}$.

2) Plantae Indiae batavae orientalis, quas in itinere per insulas archipelagi indici Javam, Amboinam, Celebem, Ternatem, aliasque annis 1815-1821 exploravit Casp. Georg. Carol. Keinwardt. Lugduni Batavorum. 1856. 



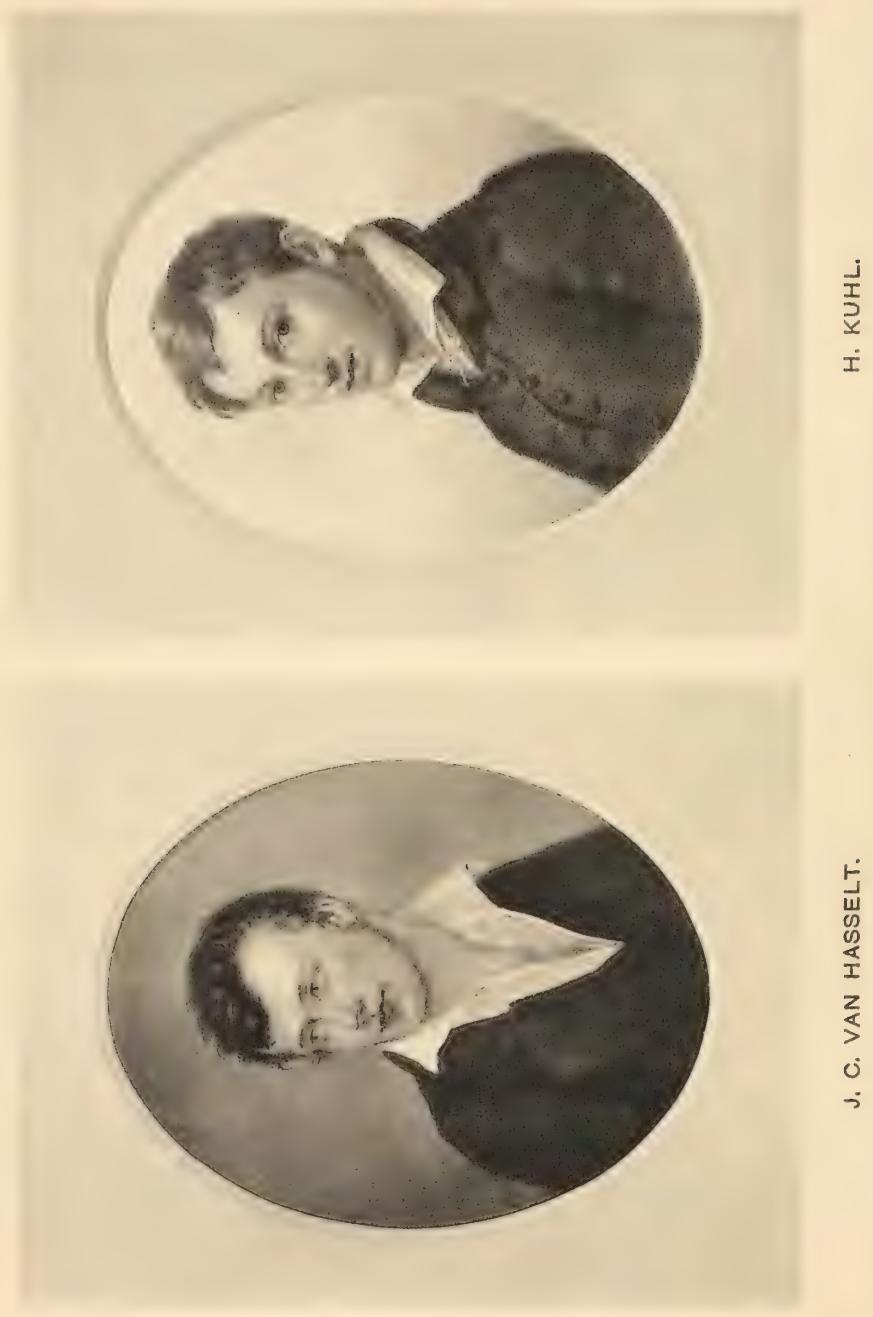


lijk als „Plantae Reinwardtianae” bekend. DE Vriese ontving bij de bewerking hulp van Miquel, Weddell, Buse en van de Saxde LACoste, terwijl behalve mossen en levermossen, slechts een I4-tal phanerogamenfamilies verschenen zijn.

Onze Regeering achtte gelukkig met de zending van ReinWARDT haar taak, het Indisch natuuronderzoek te bevorderen, niet afgeloopen; een nog veel grootscher plan werd ontworpen en in de bijzondere aandacht des Ministers aanbevolen door Van Siwinderen en Temminck, hoogleeraren te Groningen en te Leiden; een in waarheid "Koninklijk" besluit kroonde den ${ }_{2}$ den Mei 1820 de voorbereidingen. Op dien dag werd de "Natuurkundige Commissie voor Nederlandsch-Indië" in het leven geroepen.

„In aanmerking nemende", aldus vangt het bedoelde K. B. aan, „de aanstaande terugkomst van den heer REININARDT, en willende meer en meer bevorderen de kennis van de natuurlijke gesteldheid en van de voortbrengsels in de Oost-Indiën .... Hebben besloten en besluiten: De Heeren H. Kunl, Doctor in de Wis- en Natuurkunde en J. C. VAN HAsselt, worden benoemd om, onder de orders van onzen Gouverneur-Generaal, de Nederlandsche bezittingen in Oost-Indië te bereizen, met het bepaalde doel, om de wetenschappelijke kennis van de voortbrengselen der Natuur, in die landen, uit te breiden". Uit deze woorden blijkt, hoezeer het wetenschappelijk karakter der Indische Commissie op den voorgrond gesteld werd, hoe er dus een belangrijke wijziging ten goede gekomen was in de richting, waarin de Regeering meende te moeten werken. REINWARDT's opdracht was, zagen we, in de eerste plaats op de practijk gericht; de taak, aan het vriendenpaar KLHL en Van Hasselt opgelegd, was van zuiver ideëelen aard. Hun werd nog toegevoegd een ontleedkundige G. van RAALTEN en een teekenaar J. Keultjes. Behalve dat zij de beschikking kregen over een 
DE NATUURKUNDIGE COMMISSIE.

belangrijke som voor aankoop van instrumenten en hulpmiddelen, werd hun toegezegd, dat zij na afloop der reis, die op vier à zes jaar berekend was, nog gedurende drie jaar een gratificatie van $f$ I 200 zouden ontvangen, teneinde de in Indië bijeengebrachte aanteekeningen, afbeeldingen en verzamelingen te kunnen bewerken.

Hoe was de aandacht der Regeering gevallen op de twee jonge mannen KuHL en VAN Hasselt? Wie was de raadsman in deze zaak, door wiens invloed werd dit ondernemende studentenpaar voor een dergelijke zware taak uitgekozen? Ongetwijfeld was dit VAN SwINDEREN, die reeds op 29-jarigen leeftijd professor aan de Groningsche Hoogeschool was en die door zijn gemakkelijken omgang, zijn ideale gaven als leermeester, KuHL en VAN Hasselt zoowel aan zich als aan elkaâr gehecht wist te maken. Van VAN Swinderen is het getuigenis gegeven, dat hij was ,,de steeds plannen beramende, de geestdriftige, de arbeidzame", en inderdaad blijkt wel uit de levensgeschiedenissen van zijn leerlingen KuHl en Van Hasselt, hoe groot de prikkelende en aanvurende invloed was, die van hem als hoogleeraar in zijn jonge jaren (later heette hij „een ongemeen deftig en suffisant professor") uitging.

De levensgebeurtenissen van KuHL en VaN Hasselt zijn nauwverbonden; vanaf het oogenblik hunner kennismaking waren zij steeds met elkaar; samen verheugden zij zich in een voordeel, aan een van hen te beurt gevallen, samen overwonnen zij de moeilijkheden, die zij op hun weg ontmoetten. Hun beider lotgevallen na te speuren en aan het vergeetboek te ontrukken, hun jong en krachtig levensvuur, hun aanleg en wetensdrang, onweerstaanbaar zelfs in de vermoeiende en uitputtende tropen, hun liefde voor hun werk, hun geduldvolle toewijding en geduldelooze onderzoekingsbegeerte, dat alles tot één levensware en warmte-stralende schildering te ver- 
werken, is de taak geweest, waaraan GRESHOFF ${ }^{\mathrm{I}}$ ) een deel van zijn arbeid van groote waardeering gewijd heeft. Greshoff's biographie van KLHL en VAN Hasselt is niet alleen een levensbeschrijving, het is een levensafspiegeling, die het leven zelf weergeeft en den lezer doet gevoelen van hoe edelen aard de persoonlijkheid dier beide vrienden was. Treffend zijn de woorden, die GRESHOFF in het laatste stukje van zijn zoo vol warmte geschreven schets zegt: ,'t Is waar dat zij zichzelven niet gespaard hebben, maar konden zij het? Verbiê de lava, dat zij gloei...." Treffend om de groote tragiek, die er achter verborgen ligt, maar heerlijk aandoend om de groote warmte van karakter van levensbeschrijver en beschrevenen, waarvan deze woorden getuigen.

Het jaar 1797 was beider geboortejaar; Johan CoenraAi van Hasselt was de oudste zoon van den Doesburgschen burgemeester en werd op 26 Juni geboren; KuHL's vader was voorzitter van het gerechtshof in Hanau aan den Main, de merkwaardige half-Nederlandsche stad, waaraan we ook onzen Rumpinus danken, en waar Heinrich Kunl den 17 den September het levenslicht zag. Beiden toonden reeds vroeg liefde en neiging voor natuurstudie; beiden zijn, wij mogen wel zeggen ontdekt door Prof. Van Swinderen. In Januari i8I6 wordt Vax Hasselt aan de Groningsche Hoogeschool ingeschreven als medicinae studiosus, teneinde later in staat te zijn voor zichzelf en zijn moeder, (zijn vader stierf in ISIS) te kunnen zorgen. Maar in zijn vrijen tijd gaf VAN HAsselt zich geheel aan zijn natuurhistorisch werk; de onzekerheid als dienaar dier ideale wetenschap een loonend beroep te kunnen vinden, dwong hem, daarnaast zich op medische studiën toe te leggen. Dat-

r) M. Greshofr, igo3. Kuhl en Van Hasseit. Een episode in het Nederlandsch-Indisch natuuronderzoek. (Album der Natuur. 1903. p. I-22 en 60-88). 
zelfde dualisme vinden wij in KunL terug: in een zijner brieven aan zijn vriend HENDrik Bole treffen wij de volgende hiervoor gretuigende uitlating aan: "De rechtsgeleerdheid wil mij volstrekt niet in het hoofd, en ik geloof daarom het best te doen met de geneeskunde als mijn hoofdvak te kiezen, wanneer er zich niet schielijk een gunstiger uitzicht opent, dat ik mij geheel en uitsluitend aan de natuurlijke historie kan wijden". Heeft KuHL een voorgevoel gehad van wat komen zou? Het moet ons, die achteraf den ganschen loop van zaken kunnen beschouwen, wel treffen van hoe merkwaardig-profetischen aard deze woorden zouden worden.

Op een voetreis in gezelschap van eenige collega's kwam Van Swinderen in den zomer van i 8 i 6 te Hanau, kort voordat KuHL naar Heidelberg zou vertrekken om daar medicijnen te gaan studeeren. Als vanzelf komt het tot een kennismaking tusschen den jongen KuHL, die door den persoonlijken omgang met een paar voortreffelijke geleerden, onder wie de bekende botanicus K. F. von Gaertner, en door de hulp en leiding, die hij aan het naturaliën-ruilkantoor van zijn overleden leermeester, dokter LEISLER, gaf, reeds op jongensleeftijd groote natuurhistorische kennis bezat en den wat ouderen, maar als persoon nog jeugdigen, professor VAn Swinderen. De Groningsche hoogleeraar toonde hierbij over een zeldzame menschenkennis en een groote welwillendheid te beschikken; hij rustte niet voordat hij aan KuHL een assistentsplaats aan zijn museum had aangeboden en zoodoende de wetenschap en KuHL beiden een grooten dienst had bewezen. KuHL ging dus niet naar Heidelberg om daar tegen zijn natuur in medisch student te worden, maar hij trok naar ons land, naar Groningen, waarheen hem een aantrekkelijke werkkring onder Van Swinderen lokte. Zoo kwam ook hij in aanraking met VAN HASSELT, een kennismaking, die tot een levensvriendschap leiden zou. KuHL's groote faunis- 
tische kennis en VAN HASSELT'S meer theoretische physiologische studiën vulden elkaar aan; KtHL had het groote voordeel, dat hij al zijn tijd aan natuur-historisch werk geven kon, dat hij in gezelschap van VAN SwindEkEN tochten maakte en zoo ook de voor hem vreemde en daardoor aantrekkelijke zeefauna leerde kennen; VAN Hasselt moest een groot deel van zijn dagen afstaan aan geneeskundigen arbeid, maar leerde hierdoor op breeder basis werken en de niet-systematische vakken, als physiologie, waardeeren.

Een door de Groningsche Philosophische Faculteit, waarschijnlijk wel op VAN Siwinderen's voorstel, uitgeschreven prijsvraag: ,Over de geleidelijke overgangen in de klasse der zoogdieren", zette beide vrienden aan het werk; KuHL, met zijn ongetwijfeld grooter aanleg en zijn betere kennis van diervormen, behaalde de gouden eerepenning, Van Hasselt kreeg de zilveren, terwijl aan beiden het eere-lidmaatschap van het Natuurkundig Genootschap aangeboden werd (I8I 7 ). Samen werkten zij aan vergelijkend-an atomische onderzoekingen; hun "Beiträge zur vergleichende Anatomie" verscheen als resultaat daarvan in 1820 ; en samen maakten zij in 1818 een voetreis door Duitschland, waar ze o. a. met Lorenz OKen kennis maakten. In den tijd op het museum bewerkte KuHL nog een index van de museumvoorwerpen en van enkele oudere plaatwerken, waarvan de nomenclatuur niet meer in overeenstemming met die van KuHL's tijd was.

In het begin van I8I9 kreeg Kthl van uit den Haag een tijding, die hem ,als een electrische schok" trof, zoo schreef hij aan VAn Swinderen: de Minister deelde hem mede, dat „,de gunstige rapporten, welke aan den Koning gedaan waren, Hoogstdenzelven het oog op hem hadden doen slaan, als iemand, die met vrucht eene of meer koloniën van den Staat zou kunnen bereizen, ten einde de alsnog ongekende schatten, welke de 
DE NATUURKUNDIGE COMMISSIE.

natuur aldaar zoo ruimschoots oplevert, aan de geleerden van het moederland en van Europa te doen kennen". En Kunl, die wel begreep, hoe hij deze opdracht aan den invloed va: VAn Sininderen en Temminck te danken heeft, weet niet, hoe hij hun zijn vreugde zal meedeelen. Teneinde volkomen voor deze zware taak berekend te zijn, wordt hij eerst door de Regeering in staat gesteld, studiereizen naar Londen en Parijs te ondernemen, om daar de schitterende verzamelingen van British Museum en Muséum d'Histoire naturelle door te werken. Zoo gaat hij in April 1819 met Temmnck naar Londen, waar hij reeds als bekende ontvangen wordt: de Engelschen beschouwden hem, zegt Greshoff, als ,a coming man”. De rijke collecties van British Museum, van Linnean Society, van Kew Gardens hielden hem een viertal maanden bezig; den 6den Augustus vinden we hem te Groningen terug, waar hij op dien day honoris causa tot Doctor phil. bevorderd werd. Op de reis naar Parijs vergezelt VAN Hasselt hem; KunL besteedt al zijn tijd aan de verzamelingen van het Muséum, waarbij hij hulp en voorlichting genoot van Cuvier, Lamarck en Humboldt, alsook aan de plantencollecties van LeschenaulT DE LA TOUR (zie blz. 8o); VAN Hasselt's doel was het bezoeken van klinieken en hospitalen, maar toch kan hij niet nalaten een groot deel van den dag met KunL in het museum door te brengen. Reeds deze studiën in Europeesche musea stelden KuHL, in staat, een werk te schrijven van groote beteekenis, een getuigenis voor zijn groote gaven: „Beiträge zur Zoologie”, in I 820 te Frankfurt verschenen, een vooral systematische arbeid, waarin vele nieuwe soorten van gewervelde dieren beschreven werden. Daarnaast bewerkte hij een uitvoerige monographie der papegaaien, die in het negende deel der Nova Acta Ac. Caes. Leopold., een plaats vond, het geleerde genootschap, dat reeds Rumphius onder zijn leden telde, en in KuHL's tijd o. a. nog REINwARDT, 
Blume, Temminck, Van Sivinderen. Kort na hun terugkomst uit Parijs promoveerde VAN Hasselt ( 3 Mei I 820) op een dissertatie over de veranderingen tijdens de ontwikkeling der kikvorschen.

Inmiddels was het Koninklijk Besluit verschenen, waarbij aan hen beiden de opdracht gegeven werd, het natuuronderzoek van Oost-Indië op zich te nemen, en zij wachtten niet langer dan noodig was om zich van de noodige hulpmiddelen en uitrusting te voorzien. In Juli 1820 reeds vertrokken ze van Texel, hielden zich onderweg bezig met het onderzoek der zeefauna en van Madeira's rijke planten- en dierenwereld, waarvan ze steeds uitvoerige berichten aan VAN SiwindEREN stuurden, om in Dec. $18_{20}$ in Bantam den Javaanschen bodem te betreden, en kort daarna Batavia, het einddoel hunner zeereis, te bereiken. Terstond begaven ze zich van hier naar Buitenzorg, het centrum van regeering en wetenschap, waar v. D. CAPELLEN hen hartelijk ontving, en waar ze ook REINIARDT troffen, zich voorbereidend voor zijn laatste groote reis. De rijke natuur van Bogors omgeving hield hen den eersten tijd bezig; deze streek, het best onderzochte deel van Java, gaf hun voldoende materiaal om zich in de Indische fauna en flora in te werken, en natuurlijk vulden zij, dank zij hun aangeboren speurdersnatuur, ook hier nog tal van ontbrekende stukken in onze kennis aan, ook hier ontdekten zij een aantal nieuwe soorten. Hoe zeer ze het groote belang inzagen van nauwkeurige faunistische en floristische studiën voor andere biologische vakken, als bijv. diergeographie, een belang, dat in onzen tijd van overheerschende physiologische en biologische onderzoekingen vaak te klein geschat wordt, blijkt uit een opmerking van Kunl in een in Juli $182 \mathrm{I}$ te Tjihandjawar, aan den voet van den Pangerango, geschreven brief: „Het is inderdaad zeer merkwaardig, dat geene van al onze slangen op het vaste land van Indië voorkomt. Dit schijnt mij niet alleen een merkwaardig feit voor de geographische 
DE NATUURKUNDIGE COMMISSIE.

verspreiding der ophidia, maar iets zeer merkwaardigs voor de geschiedenis van het ontstaan van Java" "). Belangrijk zijn ons vooral deze woorden ter kenschetsing van KunL's verziende blik, wanneer we bedenken, dat in I $\delta_{2}$ I van eenige vaststaande evolutie-theorie nog geen sprake was.

Behalve Buitenzorgs omgeving werden de hieromheenliggende Preangerbergen: Salak, Gedeh, Pangerango bezocht en beklommen, tochten, op zich zelf reeds zwaar en vermoeiend, maar voor hen uitputtend, omdat natuurlijk in die tropische streken het verzamelde materiaal zoo spoedig mogelijk bewerkt moest worden. En toch wisten KuHL noch VAx Hasselt zich in hun arbeid te beperken, zichzelf te dwingen een langen tijd achtereen rust te nemen: er was nog zoo ontzaglijk veel te doen. Van Hasselt, de minst vurige, en eigenlijk ook de meest overleggende der twee vrienden, gevoelde dit wel als een naderend gevaar; uit zijn brieven blijkt, hoe hij vaak voor KunL's gezondheid bezorgd was, hoe hij vaak tevergeefs gepoogd heeft, KunL tot zelfbeperking te dwingen. En het noodlot wilde, dat VAN HAsselts bezorgdheid helaas niet overbodig was: na een uiterst moeitevollen tocht werden zij, overnachtend in een primitief opgeslagen hut, door zware tropische regens overvallen; uitgeput en doornat kwamen ze in Buitenzorg aan. Zijn ijzeren gezondheid deed VAN Hasselt herstellen, maar de lichamelijk veel zwakkere KuHL was tegen een dergelijke zware inspanning niet bestand; een leveraandoening deed de ziekte een ongunstig verloop nemen; KuHL stierf den I $4^{\text {en }}$ September 182 I te Buitenzorg, nog geen negen maanden na zijn aankomst in Indië. De woorden van Van Hasselt: .,KuHL's te arbeidzame geest was niet geschikt voor een land als Java, waar alles rust vordert", waren maar al te waar!

I) Algemeene Konst- en Letterbode. 1822. I. p. 99. 
Vol wanhoop klinken VAN HAsselt's woorden, waarin hij aan hun beider leermeester en vriend, VAN Swinderex, dit schrikkelijk bericht meedeelt: „Ik heb mijn vriend verloren!" En dan treft ons het waarachtige medegevoel van $r . \mathrm{L}_{\mathrm{A}}$ PELLEx, den Gouverneur-Generaal, en we krijgen eerbied voor hem als mensch, wanneer we zien, hoe deze Vax Hasselt de eenzaamheid verlichten wil, hoe deze hem in zijn huis opneemt, om hem daar te laten verplegen, om zijn door een zoo droeve ramp geschokte energie te doen herleven.

Twee dagen na KunL's dood, den i6en September, stierf ook Keultjes, de bekwame en zeer werkzame teekenaar der commissie.

Het eerste werk, dat VAN HAsselt ter hand nam na zijn herstel, was het zooveel mogelijk in orde brengen van al het totnogtoe verzamelde zoölogische materiaal; de reeds begonnen studiën over de flora aan te vullen en uit te werken, zoodat ze, indien noodig, naar Europa gezonden konden worden; verder voltooide hij in dezen tijd een monographie over de Indische hoogere Zwammen, die merkwaardige natuurkinderen, wier aantrekkelijkheid voor natuuronderzoekers altijd van een bijzondere bekoring is. KunL schreef er reeds over in een van zijn brieven; hij vermeldde, hoe hun kleuren, die in onze streken vaak dof en onaanzienlijk zijn, in deze tropische wouden zich veel sterker en helderder voordoen.

Pogingen om de door Kurl's overlijden opengevallen plaats te doen bezetten door hun vriend $\mathrm{H}$. Bore, die toenmaals assistent van TEmminck te Leiden was, faalden; de regeering was te besluiteloos om terstond het werk met kracht door te zetten. Zoo blijft Vax Hasselt alleen met VAx RaAlten, voor zoover hun gezondheidstoestand het toeliet zich bezighoudend met wetenschappelijk onderzoek. Eerst in Augustus I 822 ondernemen ze samen een tocht naar Bantam, waar de onherberg- 
DE NATUURKUNDIGE COMMISSIE.

zame en woeste natuur den onvermoeibaren onderzoeker nieuwe moeilijkheden in den weg legde, maar ook weer schatten van nieuw onderzoekingsmateriaal aanbood. Een jaar lang blijven ze hier. steeds nog verzamelend, steeds onderzoekend en afbeeldend, strijdend met het klimaat, met de hun gezondheid ondermijnende tropische ziekten, tengevolge waarvan VAN RAALteN in Maart 1823 het werk staken moest. De steeds zorgzame V. D. CApelles zond nu den teekenaar J. TH. Bik naar Bantam, om VAN RAALTEN, die naar Buitenzorg terugging, zooveel mogelijk te vervangen. En ook voor VAN HAssELT zou deze onderzoekingstocht te zwaar blijken; eind Augustus I823 wordt hij opnieuw aangetast door een hevige buikziekte, zoodat BIK alles in het werk stelt hem zoo spoedig mogelijk naar Buitenzorg te vervoeren. Een tocht met onbeschrijfelijke bezwaren wordt volbracht; op zijn verzoek reizen VAN RAALTEN en een medicus, dr. Heyl hen tegemoet. Begin September komt de treurige stoet te Buitenzorg; alle verzorging, alle welwillendheid van VAN DER CAPELLEN schoot te kort; ook VAN Hasselt werd het slachtoffer van den helaas te grooten ijver, door de eerste leden der Natuurkundige Commissie tentoongespreid. Hij overleed den Sen September I82.3; hem en zijn boezemvriend KuHL werd één graf gegraven; één gedenkteeken, door VAN DER CAPELLEN opgericht, herinnert den bezoeker van Buitenzorgs schaduwrijken tuin aan de zoo vroeg geëindigde levens dezer pioniers.

Het eerste, zoo vol moed begonnen, gedeelte van de werkzaamheid der Indische Natuurkundige Commissie had hiermede een droevig einde gevonden. Op VAN RaAlten kwam nu de verantwoordelijkheid te rusten voor de gemaakte verzamelingen; dank zij zijn goede zorgen en zijn groote nauwkeurigheid werd alles volkomen geordend in het Rijks-Museum van Natuurlijke Historie te Leiden ontvangen. En aan TEMminck komt de eer 
toe, van deze belangrijke verzamelingen te hebben gemaakt, wat er in de ongunstige omstandigheden, waarin ons Rijk in dien tijd verkeerde, van gemaakt kon worden. De door KunL en VAN HAsselt bijeengebrachte verzamelingen werden zooveel doenlijk aan specialisten ter bewerking toevertrouwd: Cuvier en $V_{\text {ALENCIENNES namen in hun standaardwerk }}{ }^{\mathrm{x}}$ ) de beschrijvingen der visschen op; BorE verzorgde in zijn „Erpétologie" "), waarvan echter, nadat een aflevering verschenen was, de verdere uitgave door den Belgischen opstand verhinderd werd, de Amphibiën, DE HAAN de insectenverzamelingen. Temmnck zelf nam in zijn "Planches coloriées d'oiseaux" ${ }^{3}$ ), een aantal vogelbeschrijvingen op en in zijn ,Monographies de Mammalogie” +) bewerkte hij de zoogdieren van KunL en VAx HAsselt.

De botanische verzamelingen en aanteekeningen werden bewerkt door Blume in zijn ,Bijdragen tot de flora van Ned.Indië" 5) en zijn ,Rumphia, sive observationes botanicae” 6), twee standaardwerken van groote beteekenis, maar waarin helaas te veel op BLuME's naam staat en te veel de schijn gewekt wordt, als zou BLcme zelf al het hierin bewerkte materiaal verzameld hebben. Hoeveel de geleerde schrijver, die volgens getuige-

I) G. Cuvier et M. Valenciennes, I828-i 849 . Histoire naturelle des poissons. Paris, Strasbourg et Bruxelles. 1828-1849. 22 vol. $4^{\circ}$.

2) H. Boie, 1830. Erpétologie. (Van dit werk is mij geen exemplaar bekend).

3) C. J. Temimnck et le Baron Meiffren Laugier de Chartrouse I83S1839. Nouveau recueil de planches coloriées d'oiseaux, pour servir de suite et de complément aux planches éluminées de Buffon. Paris, $1838-39.5$ vol. gr. in 4 .

4) C. J. Teminck, I827-I84I. Monographies de Mammalogie, ou description de quelques genres de mammifères, dont les espèces ont été observées dans les différens musées de l'Europe. Paris et Leiden. 1827-1841. 2 vol. $4^{\circ}$.

5) C. L. Blume, I825-1826. Bijdragen tot de flora van Ned.-Indië. Uitgegeven door C. L. Blume. Batavia. 1825-1826. 2 vol. ( 7 afleveringen).

6) C. L. Blume, $1835-1848$. Rumphia, sive observationes botanicae imprimis de plantis Indiae orientalis tum penitus incognitis, tum quae in libris Rheedii, Rumphii, Roxburghii, Wallichii, aliorum recensentur. Lugduni Batavorum, Amstelodami. 1835-1848. 4 vol. fol. 
nissen een ijdel en despotiek man geweest moet zijn, hierbij aan Kun en VAx Hasselt te danken had, was zijn inziens niet de moeite waard te vermelden! En nog een ander werk, tegenwoordig buitengewoon zeldzaam, en onder invloed van den Belgischen opstand eveneens onvoltooid gebleven, is op de Orchideeën-monographie van KuHL en VAN HAsselt gebouwd: prof. J. G. S. VAN BREDA, hoogleeraar te Gent, begon in I827 de uitgave ran zijn groot folio-werk ${ }^{\mathrm{T}}$ ) over de verzamelingen van Orchideeen en Asclepiadeeën, door Kuhl en VaN Hassert bijeengebracht. Zoo heeft ook prof. F. A. W. Miquel in zijn „Flora van Nederlandsch-Indië" een volledige opsomming gegeven van de door K'HL en Van Hasselt, ,verwant door een onbluschbaar verlangen naar natuuronderzoek en door een schranderheid van geest" ${ }^{2}$ ), bijeengebrachte plantencollecties.

Reinwardt had Indië verlaten; Kunl en Van Hasselt waren gevallen. Voor Plantentuin en Natuurkundige Commissie waren dit ernstige gebeurtenissen. Voor zijn vertrek had REINwaRdT overwogen, in hoeverre VAN Hasselt de aangewezen man voor zijn opvolger zou zijn; het bezwaar, dat hij veel op reis zou zijn, en toch ook nu hij alleen stond als lid der Natuurkundige Commissie, een zware taak te vervullen had, deed Reinward besluiten, niet hem, maar , den adjunct bij mij, en inspecteur der vaccine, C. L. Blusie, voor te stellen, die sedert eenigen tijd eene meer dan gewone neiging voor de beoefening der kruidkunde heeft betoond en in deze wetenschap reeds aanmerkelijke vorderingen gemaakt heeft. Hij is daarenboven reeds

r) J. G. S. van Breda, I827-I829. Genera et species Orchidearum et Asclepiadarum quas in itinere per insulam Java collegerunt Dr. H. KuHL et J. C. vaN Hasselt. Vol. I. Gent, $1827-1829$. Van dit zeldzame werk bevindt zich een exemplaar in de bibliotheek van het Koloniaal Instituut.

2) F. A. W. Miquel, I855. Flora van Nederlandsch-Indië. 3 dln. met I bijvoegsel Sumatra. Amsterdam-Utrecht-Leipzig. 1855-1860. III. Inleiding. p. VI. 



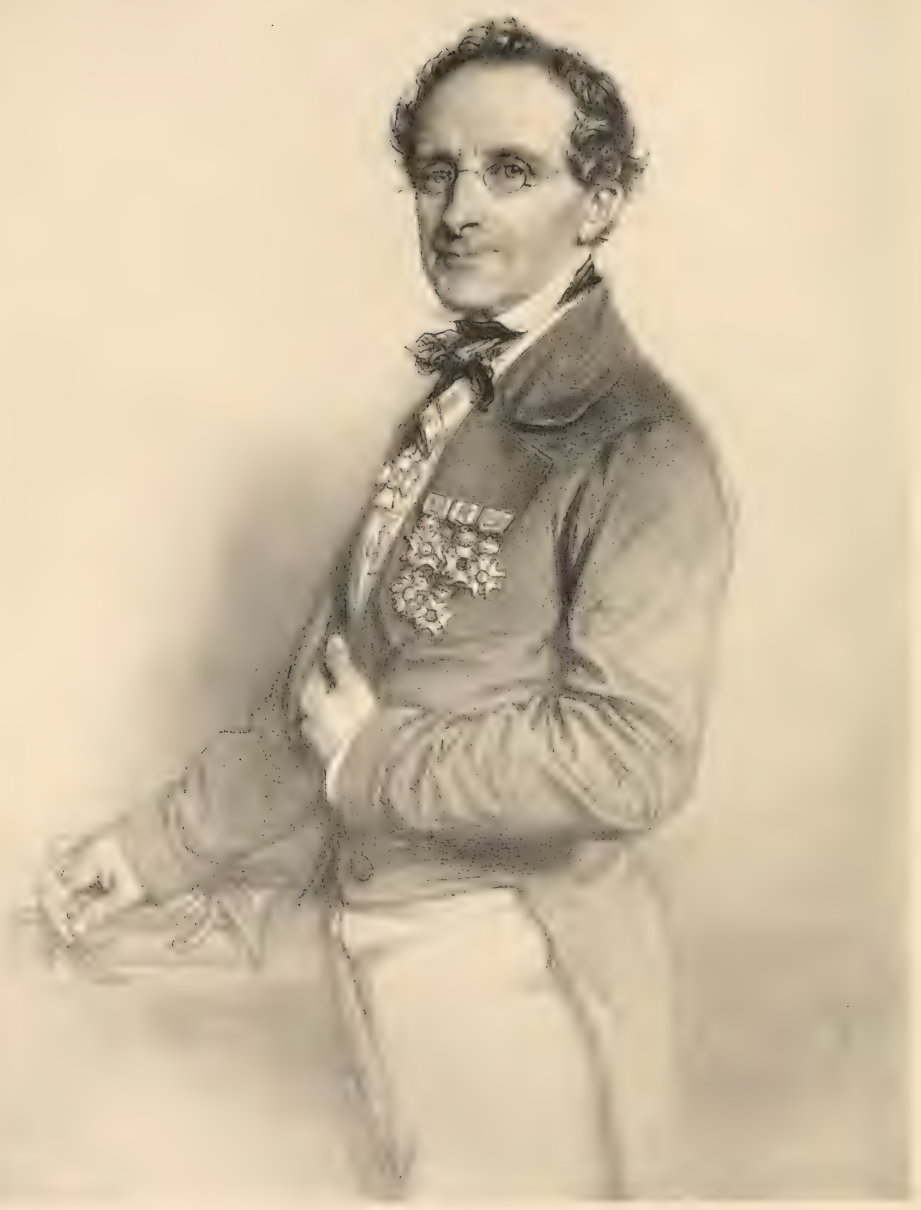

C. L. BLUME. 
bekend met al hetgeen tot den gemelden tuin betrekking heeft en deze zijne nieuwe betrekking zal voor hem tevens gedeeltelijk eene vergoeding zijn voor den thans ophoudenden post van adjunct bij mij". De beide hortulani J. Hoorer en IV. Kext bleven aan den tuin verbonden.

Carl Ludivig Bluie (geb. te Brunswijk 9 Juni i796, overl. te Leiden 3 Febr. I862) was ten volle berekend voor zijn nieuwe ambt. Terstond na de aanvaarding dezer betrekking (zijn benoeming had I I Juni I $\$ 22$ plaats), maakte hij een begin met het catalogiseeren van de voornaamste in den Hortus Bogoriensis aanwezige planten; ruim een half jaar later, den Isten Februari i 823, was het werk voltooid, en kon de „Catalogus van eenige der merkwaardigste zoo in- als uitheemsche gewassen te vinden in 's Lands Plantentuin te Buitenzorg" in het licht verschijnen. Van 912 opgesomde planten zijn er 330 met $R$. gekenmerkt, wat beteekende, dat deze planten reeds in manuscript door Reiniwardt beschreven waren. Blumie heeft zijn tijd in Buitenzorg goed gebruikt; hard en nauwgezet werker, heeft hij daar schatten aan botanisch materiaal bijeengebracht, die hem nu en later moesten dienen bij de bewerking van zijn reeds genoemde groote werken (zie blz. I07). Op zijn voorstel werd een zekere Alexander Zippelius in Dec. 1823 aan den Plantentuin werkzaam gesteld, om in Juni 1825 den hortulanus Kent, die tot ,assistent bij den Inspecteur der koffiecultuur voor het regentschap Limbangan" benoemd werd, te vervangen en dus 2 e hortulanus te worden. Zoo scheen de Plantentuin zich in regeeringsgunst te mogen verheugen, en een tijd van grooten bloei te zijn ingetreden, onder een hoogst bekwaam en werkzaam directeur Blume, en een tweetal zeer kundige en volijverige hortulani Hooper en ZipPelius.

In het voorjaar van 1826 pakten zich donkere wolken

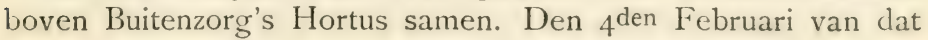


jaar had de Commissaris-Generaal, Burggraaf uU Bus ine Gisignies, het bestuur der Koloniën van v. D. CAPELLEN overgenomen, met de uitdrukkelijke lastgeving, hem in een vertrouwelijke opdracht verstrekt, zooveel mogelijk de Indische finantiën, die door $\checkmark$ D. Capellen's wel wat al te royaal beheer in ongunstige positie waren gekomen, weer in evenwicht te brengen. En als een der eerste slachtoffers van de bezuinigingswoede vinden we 's Lands Plantentuin. In een rampzalig besluit van 7 Augustus I $\$ 26$ wordt door Du Bus de post van Directeur van 's Lands Plantentuin opgeheven en wordt bepaald, dat voortaan slechts één hortulanus, onder de on middellijke bevelen van den Gouverneur-Generaal den tuin zal beheeren; zoodra Hooper of ZipPELIUS vertrok, zou hij niet vervangen worden. Juist in denzelfden tijd vertrok BLuME om gezondheidsredenen naar Europa, zoodat de opheffing van het Directeurschap geen moeilijkheden opleverde. Hoezeer we ook de bezuinigingsmaatregelen mogen goedkeuren, toch was dit radicale besluit, waardoor ReINwaRdT's stichting ernstig werd bedreigd, naar TREUB'S meening om tweeërlei redenen niet gerechtvaardigd ${ }^{ }$): „I $\mathrm{I}$ toonde de Regeering in het moederland de bezuiniging niet zoover te willen doorvoeren, door de benoemingen van nieuwe leden voor de Indische Commissie, en derhalve het natuuronderzoek van Indië krachtig te willen doorzetten; Du Bus was dus „plus royaliste que le roi", en 2 e wilde Du Bus zelf de invoering van nieuwe cultures krachtig bevorderen: thee, kaneel, kruidnagelen, peper, katoen, papaver, wijnstok, moerbeziën voor zijderupsenteelt, al die planten werden beurtelings onderzocht en hun cultuur in Buitenzorg's tuin beproefd; commissies ter bevordering van den landbouw werden in het leven geroepen, zoodat we Du Bus niet mogen verwijten, den land

I) M. Treub, I889. p. 25 . 
bouw verwaarloosd te hebben". Bovendien werd in 1829 op voorstel van de Hoofdcommissie van Landbouw, besloten tot „,den aanleg van den Gouvernements-Tuin te Weltevreden", een tuin, ,voornamelijk bestemd, om in de eerste plaats alle soorten van vruchtboomen te bevatten, die men op Java en in den Indischen Archipel aantreft, even zoo zeer als die planten en heesters, die eenige geneeskundige deugd bezitten, en vooral eindelijk die plantgewassen, die reeds zijn of zouden kunnen worden, voorwerpen voor den landbouw, handel en de consumptie" "). De geheele zaak maakt sterk den indruk, alsof het Du Bus in de eerste plaats om opheffing der directeurswaardigheid te doen was; het lijkt mij dan ook volstrekt niet onmogelijk, dat het besluit van 7 Aug. I 826 meer een persoonlijken aanval op den toenmaligen directeur Blume, wiens hooghartigheid en ijdelheid wij reeds kennen, bevatte. De „gezondheidsredenen", waarom Blume aftrad, kunnen zeer goed een papieren voorwendsel geweest zijn.

BLuME's werkzaamheid tijdens zijn Indische periode was buitengewoon; zoowel in het belang van den tuin, als in dienst der wetenschap, gaf hij zich geheel; tijdens de jaren 1822-1826 nam de tuin onder zijn beheer steeds in beteekenis toe. En al heeft Buume in later jaren, in zijn hoedanigheid van Directeur van 's Rijks Herbarium te Leiden, heel wat plannen beraamd, die, indien ze ten uitvoer gebracht waren, den ondergang van den tuin tengevolge zouden gehad hebben, toch mag dit alles ons niet Blume's groote verdiensten jegens den Hortus Bogoriensis doen vergeten. Behalve de samenstelling van den Catalogus, op zichzelf een omvangrijk en hoogst verdienstelijk werk, waarin vooral de beschrijvingen van talrijke nieuwe p. $7-8$.

I) Javasche Courant, dd. I8 April r829, no. 47. Zie P. H. V D KenP, I9I4. 
DE NATUURKUNDIGE COMMISSIE.

soorten van beteekenis zijn, werkte ButıE ook nu reeds aan zijn ,Bijdragen" "), waarvan in 1825 en 1826 ter Landsdrukkerij in Batavia een zeventiental afleveringen verschenen, tezamen een boek van meer dan elfhonderd bladzijden vormend. En van al deze bladzijden waren er slechts weinige van andere hand, al het overige danken wij aan BLLME's energie ${ }^{2}$ ). Bovendien bevatten ook de deelen 9, ro en I I van de Verhandelingen van het Bataviaasch Genootschap, hetwelk in die jaren omstreeks I $8_{25}$ in betrekkelijken bloei verkeerde, een viertal mededeelingen van zijn hand, waaronder één van meer geographischen aard: "Over de gesteldheid van het gebergte Gedé".

En de voortzetting van dit krachtig wetenschappelijk werk, dat voor de toekomst van zoo groote beteekenis zou kunnen worden, werd door het noodlottige besluit onmogelijk gemaakt, gelukkig slechts voorloopig.

Dat de Regeering in het moederland deze gevoelens van haar Commissaris-Generaal niet geheel deelde, en de bezuinigingsplannen niet zoover wilde doorvoeren, blijkt wel uit de verdere lotgevallen van de Natuurkundige Commissie, die, hoezeer ook nu en dan door geldelijke moeilijkheden in haar werkzaamheid belemmerd, toch nog tal van jaren na VAN HAsselt's overlijden een opgewekte levenskracht toonde. Nog voor het bericht van VAN HASSELT's dood het vaderland bereikt had, werden bij K. B. van 5 December 1823 tot leden der Natuurkundige Commissie benoemd Dr. H. BorE, sedert eenigen tijd conservator aan Temmincks Museum, en Dr. H. Macklot, een

ז) Zie p. 107, noot 5 .

2) Een ander belangrijk werk van Blume met betrekking tot de flora van Indië was:

Flora Javae nec non insularum adjacentium, auctore Carolo Ludovico Blume, adjutore Joanne Baptista Fischer. Bruxelles, r828. 3 vol. fol.

en: Flora Javae et insularum adjacentium. Nova Series. Scripsit Carolus Ludovicus Blume. Tomus primus. Amstelodami, I858. fol. 
vriend van BoIE en door zijn bemiddeling ook aan het Nuseum aangesteld, terwijl ter vervanging van den overleden teekenaar Keultjes aan hen werd toegevoegd Salonon Müller, een jonge man van eenvoudige afkomst, maar roor wien een belangrijke rol in het natuuronderzoek van onze koloniën weggelegd was. Een paar maanden later benoemde de Koning nog als teekenaar der Commissie een zekeren J. C. DE BRUYx, een kunstschilder, die echter al spoedig vervangen werd door P. van OORT.

Het vertrek dezer nieuwe leden zou nog langen tijd vertraagd worden: het bericht van VAx HAsselt's dood en de daarop volgende aankomst in Leiden van zijn verzamelingen en aanteekeningen hadden uitstel wenschelijk gemaakt. BorE's hulp aan het Museum bij de bewerking van dit kostbare materiaal was nog dringend noodig; Muiller's bekwaamheid in het prepareeren van dieren kwam ook hier goed te stade, en zoo werd het December $I_{2} 5$, eer de vier reizigers Texel verlieten.

Boie, Macklot en Müller waren buitenlanders. Boie’s vader was staatsraad aan het Deensche Hof en Landvoogd van ZuidDitmarsen, waar Hendrik den $4^{\text {en }}$ Mei 1794 te Meldorf geboren werd. Gedwongen zichzelf een bestaan te veroveren, vertrok hij in I8I2 naar Kiel, om zich daar op rechtswetenschap toe te leggen, hoewel hij eigenlijk met hart en ziel natuurlief hebber was. In I I $4_{4}$ verwisselde hij Kiel met Göttingen, om het volgend jaar ook deze hoogeschool te verlaten en naar Heidelberg te trekken. Hier voleindigde hij in I8I 7 zijn rechtenstudie, maar werd kort daarna door den Hoogleeraar Tiedemann, die hem om zijn grooten ijver en zijn liefde voor dierkundig onderzoek krachtig steunde, aangezocht voor het ambt van conservator aan het Heidelbergsch Zoölogisch Kabinet. In I \$2 I riep TEMMINCK hem van dezen post naar Leiden, om daar te helpen bij de organisatie en de bewerking van het Museum van Natuurlijke 
Historie $^{1}$ ). BorE had in I $\delta_{2} \mathrm{I}$ van de Heidelbergsche Universiteit het doctoraat honoris causa in de wijsbegeerte ontvangen.

Heinkich Cirristian Macklot, Frankfurter van geboorte (20 October 1799), werd, na een drietal jaren als apothekersleerling te hebben gewerkt, in 1818 te Heidelberg als student ingeschreven, en promoveerde hier I5 April 1822 tot Doctor in de Wis- en Natuurkunde en de Geneeskunde. Op BoiE's verzoek kreeg hij een werkkring aan het Leidsche Museum.

De laatste van het drietal buitenlanders, Salomon Müller, was de zoon van een Heidelbergschen herbergier. Hij kwam door een toeval met Boie en MACKLot in aanraking, wien de ijver en bekwaamheid van den jongen SALovon terstond opviel. Op hun voorstel kwam hij naar Leiden, waar ook TEмminck, die waarlijk met lofprijzingen niet royaal was, van MüLlers bekwaamheid een goeden indruk kreeg, en dan ook in 1825 aan den Minister meldde, ,dat Müller, zoo noodig, wel berekend was als reiziger op zich zelf op te treden'.

In een ongunstigen tijd (Juni 1826 ) kwamen de vier mannen in Indië aan: v. D. CAPELLEN had in Februari het bestuur aan Du Bus overgegeven, en welke plannen deze ontwierp, zagen we reeds: geld was er niet beschikbaar; in het Kon. Besluit hunner benoeming was van bezoldiging niet gesproken, alleen waren BoIE en MACKLOT ,ten opzigte der personeele uitrusting en provisioneele bezoldiging" gelijkgesteld met ambtenaren

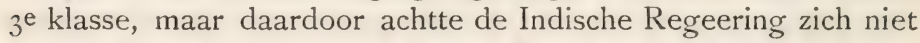
verplicht hen te onderhouden. BoIE klaagt dan ook herhaaldelijk in zijn brieven over de behandeling, die ze van Du Bus ondervonden; de oorlog op Midden-Java was wel een ernstig beletsel

r) Zie de korte biographie van BoIE in Handel. en Geschr. v. h. Indisch Genootschap: „Onderzoek leidt tot waarheid", V. r858. p. 8r. en

J. A. Susanna, i83o. Levensschets van Hendrik Boie. (In: Magazijn voor Wetenschappen enz. verzameld door N. G. van KAMPEN. X. 1830. p. 203). 
voor de regeering, „mais le traitement indigne, qu'on fait essuyer ici à une commission scientifique, envoyée par le roi, est au dessous de toute critique", en het is alleen te danken aan den eerbied, dien hij voor den Administrateur van Onderwijs enz., VAx EwIjk, heeft, dat hij de bijzonderheden niet in Europeesche dagbladen publiceert. De iste secretaris van Du Bus, VAN DE PoLL, durft hem vragen, of 3000 gulden per jaar voldoende zou zijn voor alle onkosten der Commissie en geeft hun te verstaan, dat ze de verstandigste partij zouden kiezen, door maar zoo gauw mogelijk naar huis terug te keeren. VAN RAALTEN staat aan de Commissie zijn spaarpenningen af, BoIÉ tracht zijn lotgenooten moed in te spreken en spoort ze aan geduld te hebben, en TEMminck richt een scherp schrijven tot den Minister om hem te verzoeken, den CommissarisGeneraal over het schandelijke van deze behandeling te willen onderhouden. Maar intusschen had Du Bus zelf gevoeld, dat het zoo niet langer ging: hij verstrekte hun een paar keer voorschotten, en betuigde zijn leedwezen over de vertraging, die de regeling hunner bezoldiging ondergaan had; de Regeering was ongeloofelijk overweldigd door dringende zaken. Du Bus scheen echter wel tijd te kunnen vinden, den Franschman DIARD in staat te stellen een reis naar het nog volkomen onbekende Borneo te maken, wat voor de leden der Natuurkundige Commissie natuurlijk achteruitzetting beteekende.

Eindelijk, in Februari 1827 , wordt hun positie geregeld; acht maanden na hun aankomst in Indië neemt de Luit. Gouv.-Gen. Merkus een besluit, waarbij aan Bore en Micklot een salaris van $f 500$, aan VAN RAALTEN van $f 300$, en aan MüLler en VAN OORT van $f 200$ 's maands toegekend wordt. In dien tijd had BoIE in de omstreken van Buitenzorg, die reeds door KuHL en VAN Hasselt grondig onderzocht waren, belangrijke waarnemingen over de vogelbevolking gedaan, vooral 
over hun levenswijze, hun vlucht, hun geluid, en steeds deelde hij in zijn brieven, о. a. aan TEmminck, hierover bijzonderheden mede. Een tijdlang wordt in de residentie Krawang vertoefd (Dec. IS26-Mei 1827), waar VAN RAalten op jacht door een rhinoceros zwaar verwond werd, maar gelukkig herstelde. Besloten wordt, dat de Commissie een aanvang zal maken met het onderzoek van het nog zoo weinig bekende Sumatra. Zippelius, de tweede hortulanus van Buitenzorgs tuin, sluit zich bij hen aan; het vertrek naar Sumatra wordt vastgesteld op eind September. Maar ook deze maand September zou, als reeds driemaal vroeger, voor de Commissie noodlottig worden: haar leider BoIE wordt kort na 's Konings verjaardag (25 Augustus) ernstig ongesteld, om den $4^{\text {en }}$ September te vallen als vierde slachtoffer van het tropisch natuuronderzoek. Met hem verloor de Indische Natuurkundige Commissie een talentvol en energiek leidsman.

Het pleit voor Macklots karakter, dat hij besloot aan de regeering voor te stellen, in BorE's plaats te benoemen den Franschen onderzoeker DIARD, een man van buitengewoon groote gaven, maar een zeer eigenaardige persoonlijkheid, die zich door zijn scherp en lang niet altijd even billijk optreden en gedrag tal van vijanden gemaakt had en bij Teminnck dan ook niet gunstig aangeschreven stond. Maar Diard was, zooals reeds door zijn zending naar Borneo bleek, een troetelkind der regeering; waren het Du Bus' Fransche neigingen, die hen tot elkaar brachten? En Temminck zag heel goed in, dat het voor het onderzoek van Indië van groot belang zou zijn, als DiARD de leiding op zich wilde nemen, en dat het verreweg het verstandigste was, hem voor ons land te winnen, en zoodoende zijn betrekkingen met het Muséum te Parijs te doen ophouden. Bovendien had TEmminck ook vrij sterke Fransche sympathiën, zoodat Diards landaard hem wel aanstond. Diard 
zou voorloopig te Buitenzorg blijven; MAckLot kreeg een aanschrijving om met zijn vier medeleden een expeditie te gaan meemaken naar de Zuidwestkust van Nieuw-Guinea, op welken tocht Makassar en Amboina bezocht zouden worden, terwijl ze op de terugreis Timor zouden bezoeken. Het zoo weinig bekende Nieuw-Guinea, nog slechts door enkele reizigers bezocht, Sonnerat in $177^{6}$ (zie blz. 67), Duperrey, Dumont d'Urville, Lesson (1824 en 1827), en wel vooral aan de Noordkust, had voor de leden der Commissie groote bekoring: ongelukkig moest de commandant van de Triton, het expeditieschip, reeds na zes weken verblijf voor de kust van NieuwGuinea wegens het groote aantal zieken aan boord tot vertrekken besluiten. In October $1 \$_{2} 8$ kwamen MACkLot en zijn metgezellen op Timor aan, waar de Commissie voor het onderzoek der ertsen ruim een jaar bleef en waar twee der leden, de botanicus Zippelits en de anatoom Vax RaAtex, de eenige overgeblevene van de oorspronkelijke Commissie, den dood vonden (31 Dec. 1828 en 17 April 1829). Zoowel in zoölogisch, als in mineralogisch en botanisch opzicht was deze Tritonexpeditie van groot belang.

Toen zij in het laatst van 1829 te Buitenzorg teruggekeerd waren, werd aan DiARD en MACKLOT de titel van "dirigeerend lid der Natuurkundige Commissie" toegekend, terwijl de Commissie bij Kon. Besl. van 25 Juli I 830 aangevuld werd met den botanicus P. W. Korthals en de preparateurs D. H. R. vax Gelder en B. N. Overijik. De overgebleven leden vertoefden tot de aankomst der nieuw benoemden op Buitenzorg, om dan in Mei I831 gezamenlijk, uitgezonderd DiARD, die voor de regeling te Buitenzorg bleef, een reis langs de noordkust van Java te ondernemen en langs de zuidkust terug te keeren. In het volgend voorjaar vertoefde de Commissie in Krawang, toen daar op 8 Mei het Chineezen-oproer uitbrak. Daarbij werden alle 
DE NATUURKUNDIGE COMMISSIE.

Europeesche huizen te Poerwakarta door brand vernield, ook dat, waarin MlıckLot verblijf hield en waar hij al zijn resultaten van de tochten naar Nieuw-Guinea en Timor en waarschijnlijk ook een aantal manuscripten van BorE bewaarde. MaCkLot zelf kon nog bijtijds vluchten; van zijn bezittingen werd niets gered. Bij een gevecht, den 12 en Mei daarop met de Chineezen geleverd, werd MACKLOT door lanssteken vermoord.

Teneinde alles weer zooveel mogelijk in orde te brengen, vertrok de Commissie naar Buitenzorg; maar het scheen alsof de moed om opnieuw aan het onderzoek te beginnen, sterk verminderd was. Een vol jaar hielden de overgebleven vijf leden te Buitenzorg verblijf om pas in Mei 1833 weer een onderzoekingstocht aan te vangen, en wel naar de Padangsche landen: Van OORT, Korthals en Müller vertrokken hierheen, terwijl Van Gelder en Overdijk in Januari I834 volgden.

Ook deze Sumatra-tocht zou één van de leden der Commissie als offer eischen, en weer was het de Septembermaand, die noodlottig werd: 24 September 1834 sterft P. van Oort te Padang, na een ruim achtjarig verblijf in Indië. Tot het laatst van 1835 bleven de anderen op Sumatra; voornamelijk Tapanoeli en de residentie Padang werden onderzocht. In December van dat jaar werden alle verzamelingen naar Europa verzonden.

Het had de aandacht van den Gouverneur-Generaal getrokken, dat van de talrijke reizen, door de leden der Natuurkundige Commissie gemaakt, nog zoo weinig vruchten gezien waren; het bewerken der resultaten ging z.i. niet vlug en vooral niet systematisch genoeg. De grootsche plannen door TEMMincK gemaakt, om o.a. een uitvoerig verzamelwerk: Galérie zoölogique, waarvan BorE's Erpétologie het eerste deel zou vormen, uit te geven, waren door allerlei ongunstige omstandigheden, o.a. door den Belgischen opstand en zijn gevolgen, niet tot uitvoer gekomen. Om nu de werkwijze der Commissie zoo 
goed mogelijk te regelen, vaardigde de Gouverneur-Generaal, na overleg met DiARD, een resolutie uit (27 Februari 1836 ), waarbij bepaald werd, dat Korthals en MüLler, vergezeld van den aan de Commissie toegevoegden officier van gezondheid Horner, een Zwitser van geboorte en zeer bekwaam geoloog, een tocht van vier maanden naar Borneo's Zuidoosthoek zouden maken; Korthals zou in het bijzonder voor plantenverzamelingen, MüLler voor dierkundige studies en HORner voor mineralogisch onderzoek zorgen; na terugkomst zouden Korthils en Müller naar Nederland terugkeeren om daar gedurende twee jaar aan de bewerking van hun verzamelingen mede te helpen; aan HorNer werd opgedragen, in den loop van 1837 Noord-Celebes te gaan onderzoeken, om dan op gelijke voorwaarden naar Europa te vertrekken. In deze resolutie van den Gouverneur-Generaal vinden we de namen van Overdik en Van Gelder niet vermeld; zij hadden den dienst der Commissie verlaten om een werkkring te vinden aan het onder leiding van Diard staande Museum van Natuurlijke Historie, gesticht met ondersteuning der regeering door het Bataviaasch Genootschap, waarvan de zeer bekwame Chef van den Geneeskundigen Dienst, Dr. E. A. FrITze, in dezen tijd secretaris was. Het kwijnend bestaan van dit museum was aanleiding, dat het in I $S_{44}$ opgeheven werd, waarna de verzamelingen naar Leiden overgebracht zijn.

De bloeiperiode van de Natuurkundige Commissie is na MüLler's vertrek eigenlijk voorbij; wel worden opnieuw leden aangesteld: 4 Februari 1838 Dr. E. A. Forsten, een van de weinige Nederlanders, wien, nadat hij door omstandigheden buiten zijn schuld en tegen zijn wil een vol jaar te Buitenzorg vrijwel werkeloos had doorgebracht, een reis naar Celebes werd opgedragen, na afloop waarvan hij de Molukken als arbeidsveld koos en hier op Amboina 3 Januari 1843 overleed. Forstex 
was een psychisch zeer krachtige persoonlijkheid, die hoewel hij in de tropen voortdurend met ingewandsaandoeningen te kampen had, toch erin slaagde, belangrijke verzamelingen bijeen te brengen (o.a. drie exemplaren van den tot dien tijd nog vrijwel onbekenden Nautilus I'ompilius).

In het begin van $\mathrm{I}_{42}$ wordt nog als lid der Commissie benoemd de geoloog C. A. L. M. Schivaner, Doctor in de Wisen Natuurkunde, Mannheimer van geboorte. Ook hij werd door geldgebrek gedwongen eerst ruim een jaar te Buitenzorg in werkeloosheid door te brengen; eerst daarna werd hem van regeeringswege het onderzoek naar steenkolenlagen opgedragen; met dat doel vertoefde hij van I843 tot I847 op Borneo ${ }^{\mathrm{I}}$ ). Zijn zoölogische arbeid was bijzaak; hoofdzaak voor hem was de bestudeering der geologische gesteldheid van dit nog zoo weinig bekende eiland en tevens het ethnographisch onderzoek. Schwaner was de eerste reiziger, die den tocht van Bandjermassin naar Pontianak door de binnenlanden van Borneo volbracht. Na tot 1850 te Buitenzorg vertoefd te hebben, werd hem in dat jaar opnieuw een reis naar Zuidoost-Borneo opgedragen; voordat hij zich aan deze taak kon gaan wijden, stierf hij 30 Maart i85 I te Buitenzorg.

Ook was nog aan de Commissie toegevoegd de teekenaar H. von Gaffron, die zich evenals Schwaner verdienstelijk gemaakt heeft door de aanwijzing van steenkolenlagen in de buurt van de rivier Riam Kiwa. Von GAFFron is administrateur van de kolenmijn Oranje-Nassau te Pengaron (Z.-O.-Borneo) geweest; later assistent-resident van Billiton. Zijn geschriften betreffen voornamelijk het voorkomen van ertsen in Zuid-Borneo.

г) C. A. L. M. Schwaner, 1853. Borneo. Beschrijving van het stroomgebied van den Barito en reizen langs eenige voorname rivieren van het zuid-oostelijk gedeelte van dat eiland. Op last van het Gouvernement van Nederl. Indië gedaan in de jaren 1843-47. (Uitgegeven door het Koninklijk Instituut voor de taalland- en volkenkunde van Nederlandsch-Indië). Amsterdam, 1853. 
In het vaderland werden de belangen van het natuuronderzoek behartigd door een Commissie, bestaande uit de drie Hoogleeraren Blume, Reiniwardt en Temmick; aan hen werd steeds advies gevraagd over de te nemen maatregelen en de te benoemen personen. Ingesteld den i ien September I $8_{37}$, had deze Commissie tot eersten plicht de verzorging en bewerking der talrijke verzamelingen te leiden. Müller en Korthals, die met verlof gekomen waren, moesten over de door hen bijeengebrachte collecties aan deze commissie verslag uitbrengen. En opnieuw werd een grootsch plan tot het uitgeven van een standaardwerk ontworpen; dit zou den langen titel: „Verhandelingen der Nederlandsche Natuurkundigen betreffende de voortbrengselen en gesteldheid der Nederlandsche overzeesche bezittingen" dragen. In tegenstelling met de overige plannen omtrent uitgave van de resultaten der Indische Commissie, kwam dit plan tenminste gedeeltelijk tot uitvoering; tusschen de jaren 1839 en 1847 verschenen drie folio-deelen: „Verhandelingen over de natuurlijke geschiedenis der Nederlandsche Overzeesche bezittingen door de leden der Natuurkundige Commissie en andere schrijvers, uitgegeven op last van den Koning door C. J. Temminck"; één deel bevatte de door KoRTnALs bewerkte plantkunde, één deel de zoölogische onderzoekingen door Müller en Schlegel, en één deel Land- en Volkenkunde, voornamelijk door Muíler bewerkt.

Ook nog op andere wijze toonden deze adviseurs hun taak grondig op te vatten; in 1842 diende de Commissie een "Concept-reglement voor de Natuurkundige Commissie op Java" bij den Minister in, terwijl op haar raad in Mei 1846 een ministerieel besluit verscheen, bevattende „Bepalingen tot beteren waarborg, dat de dagboeken enz. der Nat. Commissie in Ned.-Indië niet verloren gaan". Beide reglementen zijn van een zeer practischen opzet, maar hebben slechts één nadeelige 
DE NATUURKUNDIGE COMMISSIE.

eigenschap: ze zijn ontworpen, toen het te laat was. Wie er belang in stelt, kan ze in hun geheel afgedrukt vinden in de belangrijke dissertatie van H. J. VeTr, den geschiedschrijver der Indische Commissie ${ }^{\mathrm{x}}$ ). De salarisregeling werd vastgesteld; ieder lid zou na zesjarig verblijf in Indië, drie jaar Europeesch verlof krijgen, om hier zijn waarnemingen te komen uitwerken; na tien jaar lid der Commissie geweest te zijn, hadden de onderzoekers aanspraak op pensioen. Alle dagboeken, verzamelingen, enz. werden Rijkseigendom; de verzending naar Europa werd geregeld. Al deze bepalingen zouden misschien van groot nut geweest zijn, indien ze twintig jaar vroeger gemaakt waren; thans, nu de Commissie zichzelf overleefd had, was ze niet meer geschikt voor hervorming en niet krachtig genoeg voor herleving.

Het was een langzaam afsterven, waardoor de eens zoo roemvol begonnen arbeid der Commissie uitgeput werd; een droevig en weinig eervol einde werd haar beschoren door het Kon. Besl. van I7 April I850, waarvan het eerste artikel luidt: „De Nat. Commissie in Ned.-Indië wordt bij deze ontbonden'. Het dirigeerend lid Schwaner, volgens een uitdrukking van Teminck: „un rénégat, qui semble avoir pris la science comme marchepied pour parvenir au but, qu'il se proposait d'atteindre", bleef tot zijn dood, in het volgend jaar, in Indië.

Wij verlieten 's Lands Plantentuin toen deze, in beginsel zoo belangrijke inrichting door de bezuinigingsbepalingen van den Commissaris-Generaal Du Bus, zich op den rand van den afgrond scheen te bevinden (blz. I I2). En nog kwam er geen einde aan de noodlottige gebeurtenissen, die ten opzichte dezer instelling plaats grepen: allereerst het vertrek van Zippelius,

ז) H. J. Verh, 1879. Overzicht van hetgeen, in het bijzonder door Nederland, gedaan is voor de kennis der fauna van Nederlandsch-Indië. Dissertatie. Leiden, 1879. p. 99 en p. I14. 
die nog niet, zooals H. J. Vetir het voorstelt ${ }^{\mathrm{x}}$ ), een , gewezen hortulanus" van 's Lands Plantentuin was, maar waarschijnlijk een werkkring bij de, door de regeering in het moederland ondersteunde, Natuurkundige Commissie veiliger achtte dan een ambt aan 's Lands Plantentuin, geheel afhankelijk van Du Bu's' willekeur. Maar erger dan dit wetenschappelijk verlies was het dreigende besluit, door Du Bus 4 September I 827 genomen. De radicale hervormingen, door hem in 1826 ingevoerd, vergden nog te veel van de schatkist; de belangrijke som van $f 200$ 's maands, bestemd voor het onderhoud van 's Lands Plantentuin, werd ingetrokken en bepaald, dat de benoodigde gelden ontleend moesten worden aan de voor het beheer van den Buitenzorgschen Paleistuin toegestane som van $f$ I500. Wij kunnen Du Bus niet verwijten, dat hij trachtte de verwarde Indische finantiën weer in orde te brengen, maar verwonderd mogen wij ons toonen over de manier, waarop dit geschiedde: de Commissaris-Generaal krijgt $f$ I 500 per maand voor zijn tuin, een luxe-voorwerp bij uitnemendheid, terwijl de wetenschappelijke Hortus Bogoriensis af hankelijk gemaakt wordt van de willekeur van den Gouvernementsintendant. Zeker, de Plantentuin bleef bestaan, in naam tenminste, maar het is voor de ruime ontwikkeling een ramp geweest, dat een militair het opperbeheer in handen had.

Toch houdt, wij kunnen wel zeggen ondanks Du Bus, het besluit van 1827 de kiem in zich van een later zeer nuttig gebleken instelling: de bergtuinen. Bij de gronden van het Paleis behoorde ook een gedeelte bergtuin te Tjipannas in de Preanger Regentschappen; aangezien dit geen wetenschappelijke instelling was, maar een lusthof van den GouverneurGeneraal, wordt deze tuin door Du Buss niet opgeheven, terwijl

r) H. J. Veth, 1879. p. 51. 
DE NATUURKUNDIGE COMMISSIE.

de onkosten eveneens uit de som van $f$ i 500 bestreden moesten worden. Dientengevolge noemt de Comm. Gen. in zijn besluit tegelijkertijd den tuin van het Paleis te Buitenzorg, 's Lands Plantentuin en de inrichting te Tjipannas als één geheel. De drie andere bergtuinen: Tjibeureum (tegen de helling van den Gedeh), die op den top van den Pangerango en die te Kandang Badak (in het zadel tusschen Gedeh en Pangerango) werden eerst later, toen weer een bloeitijd aangebroken was (I 839 en I840), aangelegd. Een merkwaardig voorbeeld van inzicht in de beteekenis van den Hortus Bogoriensis vermeldt TREuB ${ }^{\mathrm{r}}$ ): „Toen de Capitaine de Corvette Fabre en de natuuronderzoeker BéLANGÉ, van goede aanbevelingen voorzien, aan de Regeering verzochten, op Java nuttige gewassen te mogen verzamelen, werd hun toegestaan uit den tuin te Buitenzorg al datgene te nemen, wat zij noodig hadden (Besl. van 30 Mei I 828 no. 13)".

De nawerking dezer besluiten van 1826 en 1827 deed zich tien jaar lang gevoelen. Wel werden er door de beschikkingen der opeenvolgende Gouverneurs-Generaal enkele kleine veranderingen in de regeling betreffende 's Lands Plantentuin gebracht: in November 1829 werd bijv. bepaald, dat de Hortulanus ondergeschikt zou zijn aan den Chef der Natuurkundige Commissie, en werd de Hortulanus Hooper, die in Dec. 1830 met verlof naar Europa vertrokken en op reis overleden was, eerst tijdelijk, en na 5 Maart i831 definitief vervangen door J. E. Teysinnnn, maar toch kunnen wij ons volkomen aansluiten bij de woorden, waarmee TEYsmann zelf dit tijdvak van weinig belangstelling voor den Hortus kenmerkte: „Onder het bestuur van de Gouverneurs.Generaal VAN DEN Bosch en BAUd (Januari I830Februari 1836 ) werd de Plantentuin als niet bestaande beschouwd".

s) M. 'TReub, I889. p. 4I. 



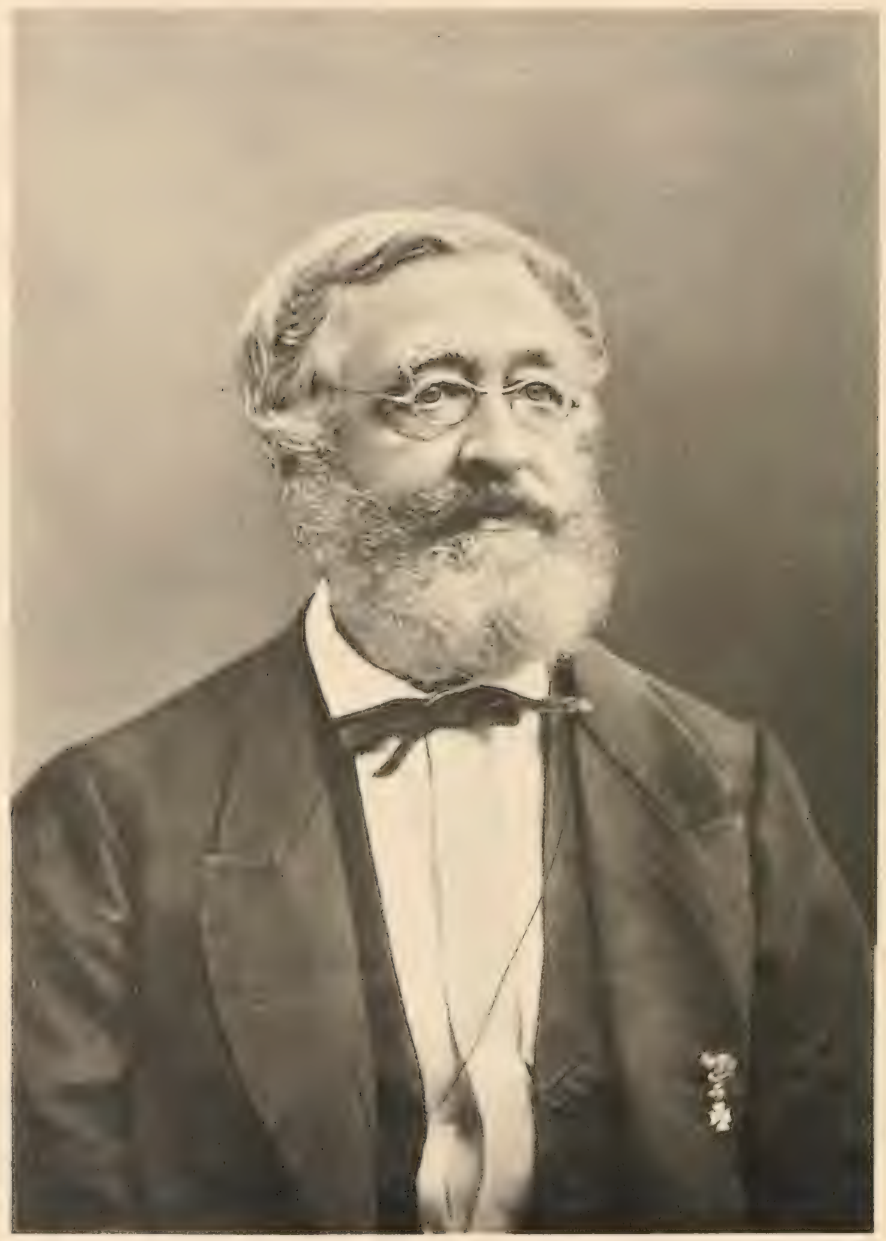

J. E. TEYSMANN. 
Toch waren de bepalingen van 2 I November 1829 en 5 Maart $1_{3} 1$ volstrekt niet zonder belang, maar het waren factoren van het toeval af hankelijk, die deze weinige regeeringsbemoeiingen van zoo groote gevolgen deden zijn. En deze factoren waren de karakters van Hortulanus Tixsmann en van den chef der Natuurkundige Commissie Diard.

Johannes Elias Tersmann ${ }^{1}$ ) had, volgens het oordeel van den eigenaar der buitenplaats „Menten berg”, waar de oude TEysmanN tuinbaas was, dominee moeten worden, al was zijn karakter verre van zachtzinnig en zijn oordeel, hoewel steeds rechtvaardig, nooit ontziend of in overbeleefde termen gekleed. Maar Temsinann JR. aangetrokken door het beroep van zijn vader, werd tuinknecht op verschillende landgøederen en kwam in $1 \delta_{30}$ in dienst bij den nieuwbenoemden Gouv.-Gen. Van den Boscr. In Buitenzorg werd hij reeds spoedig, zooals we zagen, de vervanger van den eersten hortulanus van 's Lands Plantentuin, Hooper. En juist Teysmann was degene, wiens levensloop volkomen saamgeweven werd met het opnieuw ontwaken der hem toevertrouwde botanische instelling; niet aan een waardig uiterlijk ontleende hij zijn invloed, evenmin aan parlementaire of diplomatieke handigheden, maar aan de open natuur en de rondborstigheid van karakter, die hem zoozeer eigen was. Wat Tersmann meende, dat zei hij en wat hij zeide, werd door hem gemeend. En er moest heel wat gebeuren, voordat TErsman. een plan door hem in het belang van zijn tuin geacht, zelfs al was dit tegen den zin van den Gouverneur-Generaal, liet varen. Het meest kenmerkend is wel het bekende antwoord, door Texsmann aan een der Gouverneurs-Generaal gegeven, toen deze hem verweet, ten opzichte van enkele maatregelen (het betrof het vellen van boomen) geen rekening met de

x) M. Treub, i8go. J. E. Teysirann. Eene korte schets. (Teysmannia. I. p. $I-12)$. 
DE NATUURKUNDIGE COMMISSIE.

wenschen van Zijne Excellentie gehouden te hebben. Het kwam tot een gesprek, waarin TEssuann op niet al te fijngeslepen wijze zijn meening verdedigde, zoodat de Gouv.-Gen. hem toevoegde: "Wie is hier meester, mijnheer Teysmann, u of ik?" En terstond klonk het antwoord: „Ik, Excellentie, zoolang u mij niet ontslagen hebt".

De eerste zes jaren, door Teysmann als hortulanus te Buitenzorg doorgebracht, waren voor hem een leertijd; hij trachtte zoo goed het ging zonder de belangstelling der Hooge Regeering, 's Lands Plantentuin in beteekenis te doen toenemen, zette het onder REINWARDT en Blume begonnen werk voort en zal door zijn persoon aan menig intendant van den Gouv.-Gen. eerbied afgedwongen hebben.

Onder het bestuur van den nieuwen landvoogd De Eerens, opvolger van BAUD, werd een nieuwe koers ingeslagen: een wetenschappelijk ontwikkeld man werd aan den Plantentuin verbonden. Het was J. K. HASSKarL ${ }^{\mathrm{I}}$ ), ruim drie jaar jonger dan Teysmann, maar in kennis verre zijn meerdere. Geboren te Kassel 5 Dec. i8i i, bezocht Justus Karl Hasskarl, na de verhuizing zijner familie, te Bonn het gymnasium. Maar in deze richting gingen zijn verlangens niet: hij wilde reizen en de wereld zien. Spoedig verwisselde hij het gymnasiastenpakje tegen dat van tuinmansjongen aan den botanischen tuin te Poppelsdorf bij Bonn, ging daarna plantkunde studeeren en kwam door bemiddeling van den Bonner hoogleeraar Goldfuss met een reeder uit Rotterdam in aanraking, die hem het aanbod deed, met een van zijn schepen een reis naar Indië te maken. Het plan, dat Justus bij een neef van den Rotterdamschen reeder te Batavia zou logeeren, ging niet door: de neef liet hem buiten zijn deur. Gelukkig voor HAsskarL, die geen onder-

r) Zie bijv. J. G. Boerlage, IS94. In memoriam. Justus Karl Hasskarl en zijn botanische werken. (Teysmannia. I894. p. I29-r48). 
komen had, vond hij in den reeds genoemden chef van den Geneeskundigen Dienst, Dr. FrITZE, een welwillend beschermer. Door FRITzE's invloed en door de krachtige medewerking van DiARd, den chef der Natuurkundige Commissie, kreeg Hasskarl (20 Dec. 1837) een aanstelling als assistent-hortulanus, waarbij hem op voorstel van den waarnemenden intendant Schirtex uitsluitend het botanisch gedeelte opgedragen werd. In het advies, door dezen militair aan de Gouv.-Gen. ter benoeming van HASSKARL uitgebracht, vinden wij de volgende eigenaardige opmerking: „Doch ten einde alle botsingen voor te komen, welke uit deze afgescheiden betrekkingen zouden kunnen voortvloeien, is het wenschelijk, dat zij beiden onmiddellijk onder de bevelen van den Intendant van het huis worden geplaatst". En doordat deze bepaling ook in HassKarL's benoemingsbesluit is opgenomen, is de militaire invloed op 's Lands Plantentuin nog verscherpt, en heeft de Hortus Bogoriensis, een wetens shappelijk-botanische inrichting, dertig jaar lang (tot I868) onder militaire dictatuur gezucht. Als vergoelijking voor die dwaze maatregel wordt er bijgevoegd: ,dat de geschillen, het vak betreffende, door het dirigeerend lid der Natuurkundige Commissie worden beslist".

Het was een zegen voor Buitenzorg's Tuin, dat het driemanschap Diard-Tersiann-Hasskarl steeds klaar stond zijn belangen te verdedigen, een zeldzaam Fransch-NederlandschDuitsch verbond van groote beteekenis. Want wat voor gevaren er van de zijde der militaire beheerders dreigen konden, blijkt uit een gouvernementsbesluit van i I Sept. I $\$ 40$, waarbij Tersmanv van het toezicht op den bergtuin te Tjipannas ontheven werd, op voorstel van den Kapitein-Intendant Stuten, en wel om de volgende practische redenen: ,dat er ter laatstgenoemder plaatse sedert jaren greene aardappelen aangeplant zijn, zoodat dit artikel voor het gebruik van het Gouvernementshuis te Buiten- 
zorg elders is moeten worden aangekocht"! Een verschrikkelijk verzuim van den nalatigen Teysmann! Maar het troost ons, dat reeds het volgend jaar gedaan werd, alsof dit besluit nooit grenomen was, en juist gelden voor het onderhoud der bergtuinen - er waren drie nieuwe bijgevoegd - toegestaan werden. HasskarL's verdiensten ten opzichte van 's Lands Plantentuin werden door Prof. TRELB als volgt samengevat ${ }^{1}$ ): ,In de eerste plaats werd hij, hoewel onder Teysianx geplaatst, ongemerkt diens bekwaamste en beste leermeester. In de tweede plaats was hij met zeldzamen ijver en groote bekwaamheden toegerust, de persoon, die de door DiARD gewenschte systematische rangschikking der planten in den tuin, uitvoerde, en Tersmain de noodzakelijkheid ervan leerde inzien. In de derde plaats was Dr. HasskarL de vervaardiger van den belangrijken tweeden catalogus van den tuin, voor welks samenstelling een zeer groot aantal gewassen was gedetermineerd en in den tuin uitgeplant".

„Op dit oogenblik nog dankt 's Lands Plantentuin te Buitenzorg in de allereerste plaats zijn wetenschappelijke beteekenis aan de voor een halve eeuw ingevoerde systematische rangschikking in den botanischen tuin. Aan dit denkbeeld, door Hasskarl het eerst verwezenlijkt en waaraan Teysmann, soms de hoogste tegenwerking trotseerend, streng de hand heeft gehouden, dankt de Buitenzorgsche instelling thans de mogelijkheid, om een gemakkelijk station te zijn voor buitenlandsche botanisten, die eenige maanden aan de bestudeering der tropische plantenwereld willen wijden". En ook de samenstelling van den tweeden catalogus was een werk van groote verdienste; de eerste, reeds achttien jaar geleden door Blume bewerkt, was natuurlijk door alle veranderingen in den Plantentuin geheel

ז) M. TREUB, I892, p. I3. 
verouderd. Hasskarl's tweede catalogus was reeds in 1839 gereed, maar kon door allerlei omstandigheden pas in 1844 verschijnen, nadat de bewerker met verlof naar Europa vertrokken was ( 184.3 ).

In de jaren $18_{37}-I S_{4} I$ waren het de driemannen DiARs, Teysmann en Hasskarl, die voor Buitenzorg's belangen streden; tegen een toenemende tegenwerking en een misplaatst militair opperbestuur verdedigden zij ReINwardT's instelling met een steeds krachtiger beleid. Want het waren niet alleen de dwaze bepalingen van ondeskundige militairen, waardoor de ontwikkeling van den Plantentuin belemmerd werd; veel ernstiger was de bestrijding door hooggeplaatste deskundigen, door niemand anders dan Blume en Von Siebold. Oogenschijnlijk met volkomen wetenschappelijke bedoelingen hadden deze beide heeren, van wie een nog wel Directeur van den Buitenzorgschen Tuin was geweest, in 1839 een plan ontworpen eener "Vereeniging tot invoering en aankweeking van Japansche gewassen in Nederland" en den Minister van Koloniën verzocht, aan den uittezenden kruidkundige (Dr. J. PIERot) alle mogelijke hulp van de zijde van Buitenzorgs ambtenaren te willen verschaffen. DuRd maakte van deze gelegenheid zeer handig gebruik, om de regeering te adviseeren, dat de door Pieror bijeengebrachte verzamelingen zouden moeten komen aan alle wetenschappelijke inrichtingen, aan de vereeniging van de Heeren Von Siebold en Blume, aan de Academie-tuinen van Leiden en Utrecht, maar ook aan den Buitenzorgschen Hortus.

Voorloopig was dus van Blume's en Vov Sieroln's plannen weinig nadeel te verwachten; twee veranderde omstandigheden zouden echter den toestand minder gunstig maken: DiARD vertrok in September I 84 I naar Europa en werd een jaar later opgevolgd door Schwaner, wiens eenige wensch was ongestoord op Borneo te kunnen reizen en die zich dus van de zaken den 
Plantentuin betreffende al heel weinig aantrok en bovendien werd de „Vereeniging tot invoering en aankweeking van Japansche gewassen in Nederland" omgezet in een "Koninklijke Nederlandsche Maatschappij tot aanmoediging van den Tuinbouw". Onder bescherming des Konings voelden de Heeren Von Siebold en Blume zich machtig; hun optreden werd met den dag onbeschaamder ${ }^{x}$ ): ze begonnen met aan den Gouverneur-Generaal lijsten te zenden van planten ,welke in 's Lands Plantentuin aanwezig, ter aankweeking in Nederland ten spoedigste verlangd worden" en kwamen er ten slotte toe, aan den minister van koloniën te verzoeken ,te willen zorgen, dat de planten, welke door ons uit 's Lands Plantentuin zullen worden aangevraagd, gedurende eenige jaren aan geene andere worden afgeleverd". En ingevolge ministerieele opdracht, wordt door den Gouverneur-Generaal Merkus in dien zin een besluit uitgevaardigd.

Ook in andere richting trachtte BLume de wetenschappelijke ontwikkeling van Buitenzorgs tuin tegen te werken. Reeds in I 84I had HASSKaRL, krachtig gesteund door DiARD, voorgesteld een bibliotheek en een herbarium aan te leggen; het eerste werd toegestaan; tot den aanleg van een herbarium kon de regeering nog niet besluiten.

In 1844 zette Teysmann ook dit door en wel op de hem zoo kenschetsende wijze. „Op I4 Maart I 844", aldus schrijft Prof. Treub in zijn Korte Geschiedenis ${ }^{2}$ ) ,herhaalde Teysmann het vroegere voorstel van HASSKARL, om een Herbariumlokaal te bouwen, en den $9^{\text {en }}$ April daaraanvolgende schreef hij aan den Intendant, dat een gedeelte der balken, benoodigd tot het bouwen van een Herbarium in 's Lands Plantentuin, reeds waren ingekocht, en hij zoo spoedig mogelijk een begin met het werk

ז) Zie M. Treub, 1892. p. 18-19.

2) M. Treub, 1892. p. 19 . 



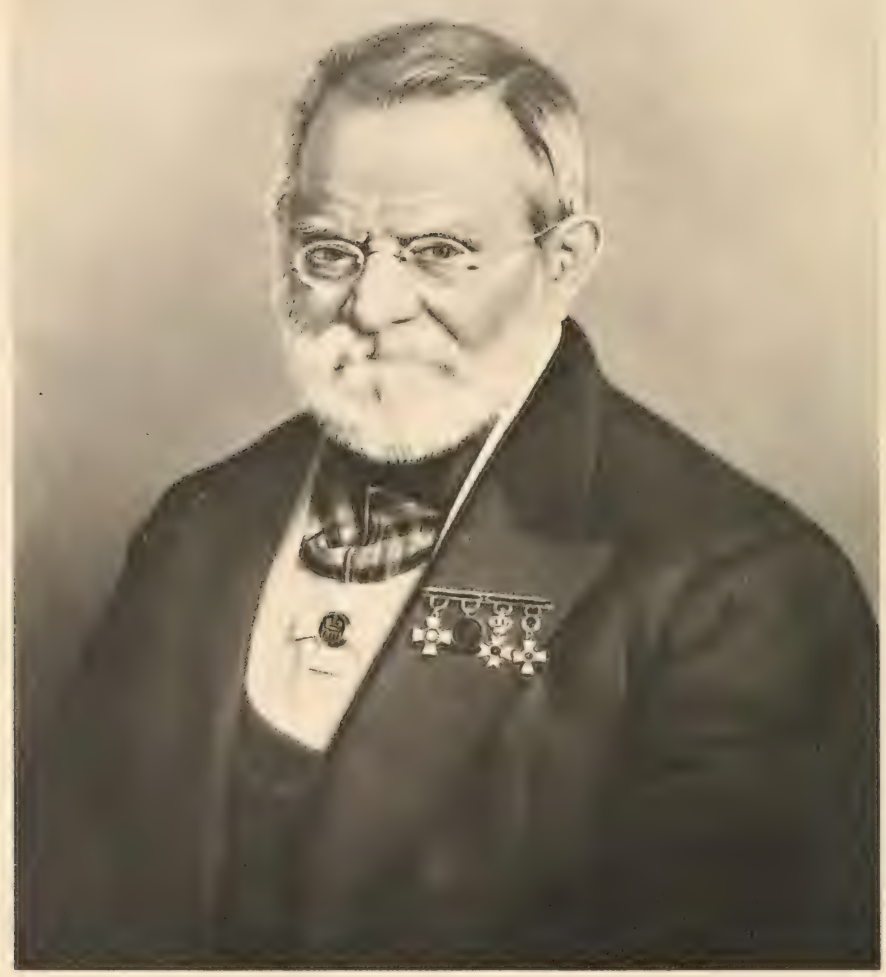

J. K. HASSKARL. 
wenschte te maken". Maar dezelfde Bucve, nu in zijn hoedanigheid van „Directeur van 's Rijks Herbarium”, vond in Teysmann's plannen een ernstige bedreiging voor zijn inrichting; hij deed aan den Minister van Kolonien (December 1844) een drietal voorstellen, die om hun brutale termen alleen reeds waard zijn, hier vermeld te worden ${ }^{\mathrm{I}}$ ): „I $\mathrm{e}$. Te verbieden, dat iemand van degenen, die bij de Natuurkundige Commissie of bij 's Lands Plantentuin op Java zijn aangesteld.... aan een ander, onder welk voorwendsel ook, eenige gedroogde planten of andere kruidkundige voorwerpen afsta, als zullende alle botanische verzamelingen bij uitsluiting aan 's Rijks Herbarium te Leijden worden afgeleverd; 2 . Te gelasten, dat alle reeds verzamelde kruidkundige collecties, zoo bij 's Lands Plantentuin op Java of vanwege de leden der Natuurkundige Commissie, als speciaal die van den Heer Junghunn, zonder eenige uitzondering, onverwijld door tusschenkomst van de Hooge Indische Regeering, naar Nederland worden afgezonden ten behoeve van

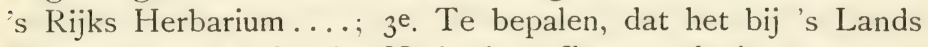
Plantentuin aan te houden Herbarium alleen zoodanige gewassen zal bevatten, welke daarin worden aangekweekt...." BLumE had voor deze voorstellen moeilijk een autocratischer toon kunnen vinden. Het advies van Schwaner luidde natuurlijk overeenkomstig BLume's voorstellen; JunghuHn gaf in krasse termen zijn misnoegen over dergelijke maatregelen te kennen en Teysmann slaagde erin, door een zeer gematigd en oordeelkundig advies, de Regeering te overtuigen van het dolzinnige en sterk onrechtvaardige van BLume's bedoelingen. De Indische Regeering besloot dan ook Buume's eischen als niet gredaan te beschouwen.

De deskundige hulp van Hasskarl moest Tersmann missen;

x) M. Treub, 1892. p. 20. 
hem was in November 1843 verlof verleend; ook de Zwitsersche botanicus Zollinger, die Hasskarls plaats na diens vertrek ingenomen had, was na vijf maanden weer op reis getogen.

HassKarl kon het echter in Europa niet lang uithouden; zijn geschokte gezondheid was daar reeds spoedig hersteld; in het begin van 1846 vinden wij hem weer in Buitenzorg terug. Maar door meeningsverschil over de hem te geven positie ontstemd, vroeg HASSKARL spoedig ontslag en vertrok nog in hetzelfde jaar weer naar Europa. Hoewel Teysuann en HassKARL in deze zaak lijnrecht tegenover elkander stonden, belette dit hen toch niet elkaars verdiensten te waardeeren. Hasskaris werkzaamheid ten dienste der zoo belangrijke Buitenzorgsche instelling had hiermede een einde gevonden; een werkzaamheid van buitengewone beteekenis, zooals duidelijk blijkt uit de uiteenzetting, door Treub ${ }^{x}$ ) gegeven. Behalve de tweede catalogus, verschenen van zijn hand nog een aantal verhandelingen in wetenschappelijke tijdschriften: "Tijdschrift voor Neerlands Indië", „Verhandelingen van het Batav. Gen.”, „Tijdschrift voor Natuurlijke Geschiedenis en Physiologie”, „Beiblätter zur Flora", terwijl hij tevens tijdens zijn eerste Indische periode, een pas in 1865 verschenen werkje schreef over enkele nuttige planten van Java ${ }^{2}$ ).

$\mathrm{Na}$ Hasskarls vertrek stond Teysmann dus weer alleen; hulp van Schwaner kon hij niet verwachten. Als opvolger werd door Teysmann Zollinger voorgesteld, die hem reeds tijdens HASSKarls verlof vijf maanden geholpen had, en steeds op zijn reizen voor Buitenzorg verzamelde; van hoogerhand werd

ז) M. Treub, I889. p. $72-76$.

$\Rightarrow$ J. K. Hasskarl, i865. Aanteekeningen over het nut, door de bewoners van Java aan eenige planten van dat eiland toegeschreven, uit berichten der inlanders samengesteld. Amsterdam, 1865 . 
echter de candidatuur van een zekeren VAN GEsker zeer bevorderd, wiens benoeming dan ook spoedig volgde. Maar gelukkig voor TErsiann bleef van Gesker slechts korten tijd werkzaam; na twee jaar (begin I 849) werd deze wegens moord veroordeeld en ontslagen. Zollinger was naar Europa vertrokken en had in zijn vaderland een goede betrekking gevonden.

In datzelfde jaar begint opnieuw een Leidsch hoogleeraar, voor wien de antwoorden, door Teysiann aan Buume gegeven, waarschijnlijk niet duidelijk genoeg waren, een veldtocht tegen den Planteniuin. "Het invoeren van gewassen van Amerika, Kaap de Goede Hoop enz. in den tuin van Buitenzorg, is steeds door mij zeer vreemd gevonden", meent bedoelde hoogleeraar. Prof. De VRiese, te mogen opmerken. Waarop Tersidicn terecht antwoordt: ,Er ontbreekt nu nog maar aan, dat alle reeds vroeger ingevoerde kultuurplanten, al ware het slechts de koffie, die thans millioenen aan het Gouvernement oplevert, weder worden uitgeroeid". En als DE VRIEsE probeert, aan het zijns inziens verkeerde ruilen van planten een eind te maken, door Wardsche kisten ledig naar Buitenzorg te zenden, die dan gevuld naar Leiden moesten terugkeeren, dan merkt TEysmann op: ,Ik zal hem doen weten, dat ik van mijne zijde alles zal aanwenden, om hem zijne kisten ledig terug te zenden", terwijl hij in een verslag meedeelt: „Het voornaamste, waarmede deze tuin in het afgeloopen jaar beschonken werd, bestaat in 8 ledige kisten, van Prof. DE VRIEse, directeur van den Kruidtuin der Hoogeschool te Leiden".

Bovendien acht DE VRiese de opengevallen plaats van assistent-hortulanus een uitstekend middel, om direct invloed op den gang van zaken in Buitenzorg te kunnen uitoefenen: een jong, bekwaam tuinknecht, Simon Binnendijk, door De VRifse speciaal daartoe opgeleid, wordt door zijn invloed als opvolger van den mislukten Van Grskler uitgezonden. Tersmann doorziet De Vriese's 
bedoeling zeer goed: "maar ik beschouw de bedoelingen van ZEd. HGde daarheen te leiden om den Plantentuin van Buitenzorg gedeeltelijk onder zijn beheer te brengen". Toch kan DE VRIEse geen klagen hebben over de wijze, waarop steeds vanuit Buitenzorg aan zijn wenschen voldaan is, ,maar het schijnt nu zijn (DE VRIESE's) gevoelen te zijn, dat zijn protégé en zendeling geheel Java in een doosje zal inpakken en aan ZEd. HGde doen toekomen". Binnendijk werd I9 Juli 1850 benoemd; een belangrijke rol in de geschiedenis van 's Lands Plantentuin was voor hem weggelegd.

Volkomen op zichzelf staand, zonder eenig verband met Natuurkundige Commissie of Plantentuin, werkte nog in Indië Dr. Pieter Frederik Hendrik Fromberg, op aanbeveling van den beroemden Utrechtschen Hoogleeraar G. J. Mulder, benoend tot landbouwscheikundige der Indische Regeering ${ }^{\mathrm{I}}$ ). Oorspronkelijk apotheker van beroep, liet FrOMBERG zich op 30-jarigen leeftijd (hij was geboren i9 Febr. 18 I I te Amsterdam) nog te Utrecht inschrijven als student in de Wis- en Natuurkunde, legde hier zijn candidaatsexamen af, werkte te Edinburgh drie jaar onder leiding van den landbouwchemicus Johnston, en promoveerde 30 Juni 1847 te Utrecht op een "Physiologischchemische verhandeling over de bestanddeelen der planten, in verband met het plantaardig leven". Kort hierop werd FronberG naar Indië gezonden, waar hij spoedig na aankomst tot „Agrikultuurchemist" der Regeering aangesteld werd. In de eerste jaren was hij veel op reis, om Java uit eigen aanschouwing te leeren kennen; zijn eigenlijke werkzaamheid, nadat hij zich in $185 \mathrm{I}$ te Buitenzorg gevestigd had, valt dan ook in de volgende periode. En nog een ander onderzoeker moet hier vermeld worden,

ז) Zie D. W. Rost van Tonningen, i859. Dr. Pieter Frederik Hendrik Fromberg. (Bataviaasch Handelsblad. 7 Febr. 1859; Hand. en Geschr. Indisch Genootschap. VI. p. $7 \mathrm{r}-78$ en Natuurk. Tijdschr. Ned.-Indië. XVI. p. 393-402). 
wiens onderzoek wel niet speciaal voor Indië van belang geweest is, maar wiens in Soerabaya gedane ontdekking een zoo belangrijk gevolg gehad heeft, dat ze hier niet vergeten mag worden: Julius Robert Mayer, die volgens Ostivald ${ }^{1}$ ) ,zu den Forschern zu rechnen ist, deren ganzes Leben der Durchführung eines einzigen groszen Gedankens gewidmet bleibt". MAYER was 25 Nov. 18 i 4 te Heilbronn geboren, bezocht een Seminarium en de Universiteit Tübingen, om medicijnen te gaan studeeren, en werd na afloop van zijn studietijd scheepsdokter op de Hollandsche driemaster ,Java”. Reeds onderweg had hem de opmerking van een ouden stuurman, dat de zee na hevige stormen steeds aanzienlijk warmer was dan tevoren, belang ingeboezemd, en toen nu MAYEr tijdens zijn verblijf te Soerabaya (4 Juli-27 Sept. I840) verschillende matrozen een aderlating deed ondergaan, bemerkte hij dat Europeanenbloed in de tropen een veel lichtere kleur heeft, dan in Noordelijke streken; ook vond hij hiervoor spoedig de verklaring, dat de hooge temperatuur in deze omgeving veel minder warmteproductie, en dus veel minder oxydatie in het lichaam noodig maakt. Dat bracht hem op het spoor van de wet van het behoud van arbeidsvermogen en van de mogelijkheid, dat beweegkracht in warmte wordt omgezet en omgekeerd. Langzamerhand begint zijn opvatting hierover te rijpen: in Juni I84 I zendt hij een verhandeling: "Ueber die quantitative und qualitative Bestimmung der Kräfte” aan Poggendorf voor zijn Annalen der Physik und Chemie. Maar Poggendorf weigert de opname, stuurt zelfs het handschrift niet terug, deels, omdat hij het werk van MAYER niet rijp en nog niet voor publicatie geschikt acht, deels ook omdat er in de wetenschap een verlangen naar feiten heerschte en .

х) Wilh. Ostwald, I909. Julius Robert Mayer. (In zijn: Grosse Männer. Leipzig, 1909. p. $6 \mathrm{i}-100)$. p. 67 . 
natuur-philosophische beschouwingen minderwaardig geacht werden. De eerste grond was volkomen terecht ${ }^{\mathrm{I}}$ ), waar MAYER zelf schrijft, dat hem pas in het najaar van I $\$_{4}$ I de zaak helder voor den geest stond. Daarom zendt hij in Maart 1842 zijn klassiek geworden verhandeling: „Bemerkungen über die Kräfte der unbelebten Natur" aan LiebiG, die dan ook spoedig aan dit artikel een plaats in zijn ,Annalen der Chemie und der Pharmazie" inruimt. En de tweede beweegreden was oorzaak, dat Poggendorf ook nog in I847 opname van Helmholtz' „Ueber die Erhaltung der Kraft" weigerde.

Ook in dit tijdvak ontbraken niet de zeereizen, meest met een politiek doel gedaan door oorlogsschepen, aan boord waarvan zich dan natuuronderzoekers bevonden, die met het botanisch en zoölogisch onderzoek der bezochte streken belast waren. Weer zijn het Franschen, aan wie wij de belangrijkste expedities in dezen tijd danken. Allereerst de reis van de „Uranie” onder leiding van FREYCINET (I8I 7-1820), waaraan als botanicus Gaudichaud deelnam. Van onze koloniën werden o.a. bezocht Timor, Alor en de oostelijke Molukkeneilanden Poeloe Pisang, Rawak en Waigeoe. Nadat de „Uranie” bij de Falklands eilanden vergaan was, werden de verzamelingen, die voor 't grootste deel gered waren, op de „Physicienne” overgebracht en de reis naar Frankrijk met dit schip voortgezet. Het reisverhaal ${ }^{2}$ )

I) Zie A. von Oettingen, igog. Robert Mayers wissenschaftlicher Entwicklungsgang im Jahre I84r. (Abh. d. math. phys. Klasse der Kgl. Sachs. d. Wiss. Bd. 31. No. III. 1909).

2) L. DE Freycinet, 1824-1844. Voyage autour du monde, exécuté sur les cor vettes l'Uranie et la Physicienne, pendant les années 1817-1820. Paris, 1824-1844.

Histoire du Voyage. 2 tom. (4 vol.), 1825-1837.

Zoölogie par Quoy et GaIMARD. I vol. I824. Magnétisme terrestre. I vol. I842. Botanique par Cha. Gaudichaud. I vol. 1826. Météorologie. I vol. I844. Observations du pendule. I vol. r826.

Navigation et Hydrographie. 2 tom. I vol. 1826. 
waarin Agrardi, Persoon en Schwaegrichex de Kryptogamen bewerkten, Quor en Amard het deel Zoölogie, verscheen in de jaren I824-I844. Dan volgt de tocht van de "Coquille" onder leiding van Duperrey ${ }^{1}$ ), die van onzen Archipel vooral Waigeoe, Boeroe en Ambon, later ook Soerabaya bezocht. De apotheker Lesson zorgde voor het bijeenbrengen der verzamelingen; bij de bewerking der zoölogische collecties verleende Garnot hulp, terwijl Dumont d'Urville, de tweede officier der Coquille, Bory de St. Vincent en Brogriart aan het botanisch gedeelte hun medewerking verleenden. Dezelfde DuMONT D'URVILLE was gedurende I826-1829 commandant van de "Astrolabe”, aan boord waarvan de apotheker Lesson weer voor de verzamelingen zorgde; verschillende plaatsen in het oostelijk deel van ons Indië werden bezocht. Van het reisverhaal $^{2}$ ) dat in $s_{30}-1 s_{34}$ verscheen, werd het plantkundig deel bewerkt door Lessos en Richard. Ten slotte was het weer Dunont D'Urville, die de laatste Fransche expeditie in

I) L. J. Duperrey, 1826-I8 38 . Voyage autour du monde, exécuté par ordre du Roi. sur la corvette „LaCoquille”, en I822-I825, publié par L. J. DUPERrey. Paris, $1826-1838$.

[Histoire], Hydrographie et physique, I829-1830.

Histoire du voyage, 1826 .

Botanique, i 828, par M. M. d’Urville, Bory de St. Vincent et Ad. Brogniart. Cryptogamie par Bory de ST. Vincent.

Zoölogie, I826-I838 par Lesson et GARNot.

2) J. Dumont D'URville, I830-1834. Voyage de la corvette l'Astrolabe, exécuté par ordre du Roi, pendant les années $1826-1827-1828-1829$, sous le commandement de M....

Histoire du voyage. Paris, $1830-1833.5$ tomes en 10 part. $8^{\circ}$ et Atlas. 2 tom. fol.

Faune entomologique de l'Océan Pacifique par le Dr. Borsduval. Paris, i $8_{32}$. Zoölogie par Quor et Gaimard Paris, 1830-r833. 4 vol.

Botanique par A. Lesson et A. Richard. Paris, I832. I vol.

Philologie par D'URville. Paris, $1833-1834$. 2 tom. en I vol.

Observations nautiques, météorologiques, hydrographiques et de physique.

Paris, $183.3-34.2$ tom. en $\mathrm{x}$ vol. 
dien tijd leidde: de tocht naar de Zuidpool en den Grooten Oceaan met de "Astrolabe” en de "Zélée”. Bezocht werden o.a. Ternate, Ambon, Aroe-eilanden, Ceram, Makassar, Mindanao, Batavia en Zuid-Sumatra. Van de door den scheepsdokter Dr. HombroN bijeengebrachte plantenverzamelingen werd een deel door hemzelf, een deel door Montagne en Decaisne bewerkt. Het geheele reisverhaal $^{\mathrm{I}}$ ) verscheen in $184 \mathrm{I}-\mathrm{I} 854$ als standaardwerk van 23 tekstbanden en 6 banden atlas.

In het laatste deel van dit tijdvak vinden we nog de expeditie der "Samarang", in de jaren 1843-1846, onder leiding van den commandant Sir E. Belcher ${ }^{2}$ ).

Van groote beteekenis waren al deze reizen wegens de belangrijke bijdragen tot de kennis der tropische zeefauna en den plantengroei van de bezochte eilanden. Voorloopig nog orienteeringsarbeid, zou al dit onderzoek later strekken tot grondslag voor de wetenschap, die van de verspreiding der dieren en planten een verklaring geven moet: de zoögeographie van ons Indië en de plantenaardrijkskunde.

Overzien we nu nog eens, wat de eerste helft der negen-

I) J. Dumont d'Unville, I84i-i854. Voyage au Pôle Sud et dans l'Océanie sur les Corvettes l'Astrolabe et la Zélée, exécuté par ordre du Roi pendant les années 1837-r840. Sous le commandement de M. J. Duiront D'Urville. Publié sous la direction de M. JACQuinot.

Histoire du voyage par Dumont d'Urville et C. A. Vincendon-Dumoulin. Paris, $184 \tau-\mathbf{r} 846$. 10 vol.

Zoölogie par Hombron et JACQuinot. Paris, i846. 5 vol.

Botanique par les mêmes et Decaisne et M. C. Montagne. Paris, I845, 2 vol. Anthropologie et Physiologie humaine par Dumoutier. Paris, 1854. I vol. Minéralogie et Géologie par J. Grange. Paris, i846. 2 vol.

Physique par Vincendon-Dumoulin et Coupvent-Deseors. Paris I846. I vol. Hydrographie par Vincendon-Dumoulin. Paris, 1843-1847. 2 vol.

2) E. Belcher, I848. Narrative of the voyage of H. M. S. Samarang, during the years $1843-46$; employed surveying the islands of the Eastern Archipelago, accompanied by a brief vocabulary of the principal languages. With notes on the natural history of the islands, by A. Adams. London, I848. 2 vols. 
tiende eeuw voor het Indisch natuuronderzoek opleverde, dan blijkt, dat de Regeering volkomen overtuigd was van het nut eener grondige bestudeering onzer Oostersche koloniën en dat ze daaraan schatten heeft ten koste gelegd. Gebrek aan systeem in werkzaamheid, gepaard met ontmoedigende tegenwerking van het noodlot, was oorzaak, dat de resultaten niet bleken te zijn als verwacht had mogen worden; daarbij kwamen menschelijke fouten als ijdelheid en onverdraagzaamheid, heerschzucht en afgunst, die vaak in de beslissingen over belangrijke zaken een te groote rol speelden.

Belangrijk is de vooruitgang in deze periode op het gebied van kennis der flora en fauna; vooral de plantengroei der Indische eilanden werd in het bijzonder bewerkt. Een toepassing vond de kennis der floristiek in de plantengeographie, ten opzichte waarvan JcxGHuHs verdiensten onsterfelijk zijn ${ }^{\mathrm{I}}$ ). West-Java werd door de meeste reizigers als arbeidsveld gekozen, Oost-Java vooral door JunghuHn en ZoLlinger bereisd. Uit den aard der zaak hadden bijna alle floristische onderzoekingen betrekking op phanerogamen; toch ontbraken ook kryptogamen niet in de collecties: vooral Fungi, die op den onderzoeker steeds weer bekoring uitoefenen, werden verzameld (KLHL, Van Hasselt, Junghunn).

En de resultaten der Natuurkundige Commissie op het gebied der dierenwereld waren misschien niet in overeenstemming met de ontzaglijke offers, die dit onderzoek geëischt had, onbelangrijk waren ze in geenen deele. Zoo vinden we reeds in 1846 een baanbrekende verhandeling van SALomon Miuller over de Zoögeographie ${ }^{2}$ ) van Ned.-Indië.

x) Zie het volgende hoofdstuk.

2) Sal. MÜller, i846. Ueber den Character der Thierwelt auf den Inseln des Indischen Archipels, ein Beitrag zur zoölogischen Geographie. (Arch. f. Naturgesch. XII. 1. 1846. p. 109-128). 
DE NATUURKUNDIGE COMMISSIE.

Geologische studies worden vooral gemaakt door Horsfieli, Horner en JunghuHn; palaeontologische verzamelingen van de op Java zoo belangrijke Tertiair-formatie alweer door JungHUHN ${ }^{\mathrm{I}}$ ). En behalve deze meer beschrijvende wetenschappen vinden we in deze bloeiperiode een eerste begin van toegepaste wetenschap: landbouw-scheikundige onderzoekingen van FromberG, cultuurbevordering door 's Lands Plantentuin onder Teysmann en Hasskarl.

Met de opkomst en ontwikkeling der natuurwetenschappen in Europa ging een steeds krachtiger leven in ons Indië samen.

г) Zie K. Martin, I9Io. Junghuhn's Ansichten über die versteinerungsführenden Sedimente von Java. (Junghuhn-Gedenkboek, I910. p. 95-104) en het volgende hoofdstuk. 



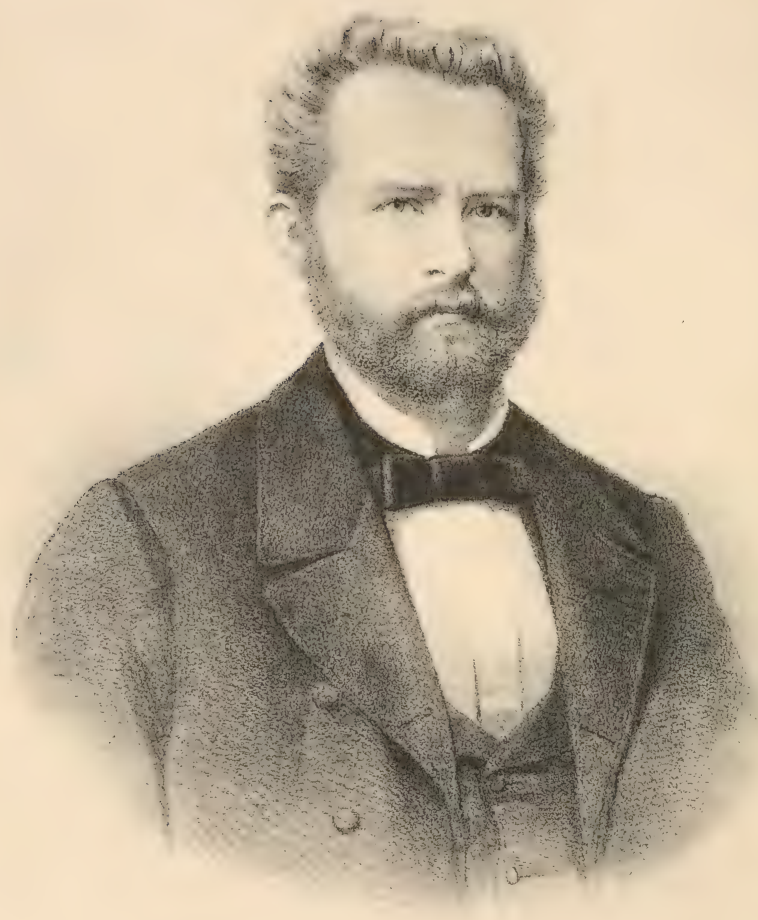

F. W. JUNGHUHN. 


\section{HOOFDSTUK V. \\ F. W. Junghuhn.}

Officieel bestond de Natuurkundige Commissie, op het oogenblik der opheffing, uit drie personen: Salodion Müller, die in Europa vertoefde, en wien den rgden Juli eervol ontslag verleend werd, in te gaan op I Jan. I850, Schwaner in Indië, en F. W. Junghuhn, eveneens met verlof in Europa. Deze laatste, bestemd om op het gebied van Indisch Natuuronderzoek een der groote mannen te jworden, werd in het ontbindingsbesluit als lid der Commissie vermeld, en was ook reeds 25 Mei I 845 als zoodanig aangesteld, dus naar de letter lid der Commissie. Maar Junghunns karakter was er in het geheel niet naar, zich in het keurslijf eener officieele commissie te kunnen schikken en zich aan het oppergezag van mannen als Blume en Temminck te willen onderwerpen.

Franz Wilhela Junghun was in den volsten zin een persoonlijkheid. Het gedenkboek, bij de viering van het eerste eeuwfeest zijner geboorte uitgegeven (I909), doet reeds op de eerste bladzijden, in de chronologische tabel zijner levensgebeurtenissen, inzien, dat Juxghums niets hooger stelde dan zijn zelfstandigheid. En deze drang naar onafhankelijkheid gaf 
F. W. JUNGHUHN.

hem, waar dit noodig was, een karaktermoed tegenover hooger geplaatsten en een onmeedoogende strijdkracht voor wat hij als rechtvaardig beschouwde, dat wij, al mogen zijn uitingen wel eens wat te fel geweest zijn en al zag hij van zijn aanvalsstandpunt de verdiensten van de betrokken personen vaak in een te ongunstig licht, toch niet anders dan grooten eerbied kunnen hebben voor dezen man, van wien niet getuigd kan worden, "dat hij geen vijanden had".

Wilskracht kenmerkte het geslacht der Mansfelder Junguunns; grootvader en vader waren beiden mannen van temperament, gemakkelijk in den omgang zoolang niets hen hinderde, maar standvastig en misschien wat eigenzinnig, indien hun meening verdedigd moest worden, zich verheffend boven de kleinsteedsche geest, die het gansche stadje, waar ook LuTHERs jeugdjaren doorleefd werden, doortrokken had. Is het wonder, dat de jonge FRANZ, die zijn geheele jeugd thuis doorbracht, zijn karakter niet leerde verloochenen? De eerste tien jaren van zijn leven (26 October I 809 was hij geboren), was hij eenig kind; een paar jongere zusjes stierven vroeg, terwijl de andere kinderen ro tot I 6 jaar jonger waren dan FRAnz, de oudste van het gezin. Zijn opvoeding en onderwijs lieten dan ook niets te wenschen over; privaatlessen leidden hem voor de universiteit op. Zestien jaar oud (September I 825), trekt hij naar Halle, om daar zijn voorbereidende kennis te volmaken, doet na anderhalf jaar zijn toelatingsexamen en wordt nu ( I Juli I 827) als medicinae studiosus ingeschreven. Maar deze geregelde studie kan den avontuurlijken FRANZ geen bevrediging schenken; na twee jaar, vaak door reizen naar Thüringen, den Harz en Brunswijk onderbroken, geeft hij het op en verlaat Halle, om naar Mansfeld terug te keeren. Hier doorleeft hij een jaar van zijn ,Sturm- und Drangperiode"; hier houdt zijn steeds onderzoekende geest zich bezig met de bestudeering 
der fungus-flora van Mansfelds omgeving; hier publiceert hij zijn eerste wetenschappelijke verhandeling ${ }^{2}$ ) over nog weinig bekende paddestoelen, zijn lievelingsplanten (,eine Traumwelt der Pflanzen" noemt hij ze), maar hier ook dwaalt zijn geest af en vinden we hem in het voorjaar ernstig gewond door een poging tot zelfmoord. In deze jaren komt JunGHuHNs denken in opstand tegen de hem door den Archidiaconus HEck ingeprente bijbelleer; hij zoekt uitkomst en ziet die in een wanhoopsbui alleen in den dood. Maar zijn krachtig gestel overwint den aanval; JunGHuHN zelf ziet er steeds met zekere angstvalligheid op terug; hij zwijgt er zooveel mogelijk over.

Als de gevolgen van deze droevige daad voorbij zijn, is ook de crisis in zijn geestelijk leven geweken. Toch is in Berlijn, waarheen hij in den zomer van i 830 vertrok, om zijn medische studiën te voltooien, Junghuns geestesstrijd nog niet volstreden. „Des Lebens Rad hat rücksichtslos an ihm herumgeschliffen. Aber zuletzt hat sich herausgestellt: der spröde Stein, an dem es schliff, war trotz seiner rauen Aussenseite doch ein Diamant”, zegt MAx Schimd zoo mooi in zijn „FraNz JunghumN" ${ }^{2}$ ). In Maart I83 I neemt hij deel aan een duel, waarbij zijn tegenstander volkomen ongedeerd bleef; hijzelf werd verwond. Evenwel was het niet in het belang van het oorlogvoerende Pruisische leger, waarbij hij in April in dienst trad en spoedig Compagnies-chirurg te Laubach werd, de hem daarvoor opgelegde straf reeds nu ten uitvoer te brengen; eerst ,als die Armee demobil gemacht und auf den Friedensfusz gesetzt wurde", zoo merkt Junghunn niet zonder bitterheid zelf

I) F. Junghuhn, 1930. Observationes mycologicae in species fungorum tam novas tam male cognitas. ("Linnaea", V. 1830. p. $388-410$ ).

2) Max C. P. Schmidt, rgog. Franz Junghuhn. Biographische Beiträge zur hundertsten Wiederkehr Seines Geburtstages. Leipzig, 1909. p. 63. 
F. W. JUNGHUHN.

in zijn "Flucht nach Afrika" ") op, werd hij (25 December I831) gevangen genomen en naar de vesting Ehrenbreitstein gebracht, ( I Januari), waar hij zijn tienjarige vestingstraf zou moeten doorbrengen. Maar een karakter als JunGHuHN laat zich niet dwingen; nadat hij een tijd lang gehoopt heeft op begenadiging en deze nog steeds uitblijft, besluit FRAnz zich zelf de vrijheid te hergeven; eerst schroomvallig, later met zeker welbehagen houdt hij zich, alsof de maandenlange gevangenisschap zijn geestesleven verstoord heeft en hij daardoor krankzinnig geworden is. Door drie geneesheeren werd hij voor ,total wahnsinnig" en zijn verstand voor ,hoffnungslos verloren" verklaard. Prachtig is de ironie, waarmee Juxghunn over de geneeskundige behandeling schrijft: „Sie überhäuften mich, fast mitleidig, mit den probatesten und auserlesensten Pülverchen und Tränkchen. Da gab es Resolventia, Alterantia, Narcotica und Belladonnapülverchen die Menge, die aber natürlicher Weise einen andern Weg als den beabsichtigten durch den Tractus Intestinorum nehmen muszten - weil ich bange war, davon wirklich toll zu werden". En als gevolg werd Junghunss wensch vervuld: hij werd minder nauwlettend gadegeslagen. Eindelijk, I 3 September I833, aangedreven door een ,nahmenlose Wehmut, eine Sehnsucht nach dem Busen der alliebenden Natur, von der ich so lange getrennt war", besluit hij te wagen; en het gelukt. Twintig maanden had hij geleden.

Een half jaar dient hij in Algiers bij het vreemdelingenlegioen; na een ongesteldheid wordt hij met verlof gestuurd, trekt naar Toulon en Parijs en komt hier met de botanici De Jussieu, Brongniart en Persoon in aanraking. Hier verneemt hij, dat de Koning van Pruisen hem begenadigd heeft en wordt hij door PERsonon overgehaald, in Nederlandschen dienst te treden.

г) 1834. Zie Max C. P. Schmidt, 1909. p. 168. 
F. W. JUNGHUHN.

$\mathrm{Na}$ een afgelegd examen ontvangt hij I 2 Januari $1 \$_{35}$ zijn benoeming tot officier van gezondheid $3^{\mathrm{e}}$ klasse, bestemd voor Java; I3 October zet hij te Batavia voet aan wal.

Thans heeft hij het land zijner droomen bereikt, het bekoringrijke eiland, waar hij bevrediging voor zijn drang naar natuuronderzoek vinden zou. Door één verlofsperiode onderbroken (27 Aug. 1848-18 Juli I 855), wordt zijn verdere leven aan het naspeuren van Java's rijke natuur, van plantengroei en dierenwereld, van vulkanengeschiedenis en tempelhistorie, gewijd. Onvermoeid en rusteloos is hij altijd door aan den arbeid; machtige, onweerstaanbare aantrekking oefent op hem de steeds boeiende tropische natuur uit. Hij vergeet, dat hij eigenlijk geneesheer is, stelt de belangen van zijn patiënten achter bij die vạn zijn wetenschap; de herhaalde reizen, die de Regeering hem opdraagt, zijn hem een te groote verlokking en een veel meer ideale levenswijs, dan het geestdoodende hospitaalleven. Eerst is het de ruimdenkende FrITzE, de chef van den Geneeskundigen Dienst, die hem op zijn inspectiereizen meeneemt, zelf de geologie van Java bestudeert en aan zijn adjudant de studie van den plantengroei opdraagt. Met hem makkt Jungiunn reizen door de Preanger Regentschappen, door Oost-Java van Semarang tot Besoeki, en vooral worden hierbij de talrijke en bekendste vulkanen bezocht. En na Fritze's overlijden (Mei I839), maakt Juxghurn vanuit Batavia vaak uitstapjes naar Wijnkoopsbaai, Gedeh, Pangerango, Bandoeng met den Malabar. In dezen tijd moet ook een voorloopige toevoeging van Jungriurn aan de Natuurkundige Commissie plaats gehad hebben; maar deze opdracht was van korten duur. JuxGHuHn's geest was niet geschikt voor lid van een commissie; als zoodanig verloor hij te veel van zijn zelfstandigheid. En na Fritze is het de G.-G. Merkus, later zijn het Rochussen en PAHUd, aan wie zijn wetenschappelijke werkzaamheid belang- 
rijker toescheen, dan zijn taak als officier van gezondheid. Aan hen dankt hij den steun der Regeering en de herhaalde toestemming om Indië te mogen bereizen: door hun medewerking bezoekt hij de residentie Kedoe, eenige malen de Preanger, Midden-Java, Salatiga, Krawang, eigenlijk geheel Java en buiten Java de Batak-landen op Sumatra (Oct. I840-Maart 1842). Ondertusschen had hij na afgelegd examen zijn benoeming ontvangen tot officier van gezondheid $2 \mathrm{e}$ । klasse.

In Mei i 845 wordt Junghunn definitief benoemd tot lid der Natuurkundige Commissie, onder gelijktijdige toekenning van zijn eervol ontslag als officier van gezondheid. Veel verandering brengt hem deze onderscheiding niet; het vergemakkelijkt zijn reizen eenigszins, maar overigens blijft zijn levenswijs vrijwel dezelfde. Aan het oppergezag, dat Blume en Temminck over de Natuurkundige Commissie meenen te hebben, stoort JunghunN zich volstrekt niet; zijn wetenschappelijke mededeelingen zendt hij niet naar Holland voor de „Verhandelingen over de natuurlijke geschiedenis" want, zegt hij in de voorrede van zijn "Java": "Ik voelde geene roeping om bij het optreden voor het publiek met een wetenschappelijken arbeid, zulks te doen als de dienaar van een mede-natuuronderzoeker, en ik was niet onbescheiden genoeg om den wensch te koesteren, dat mijn geringe arbeid zou worden opgenomen in zulk een kostbaar werk als de "Verhandelingen enz." Junghunn had een grenzenlooze verachting voor de ijdelheid der Leidsche hoogleeraren, en wist dit dan ook zeer vaak door fijnen spot en scherpen hekel te doen blijken.

Zoo doorleeft hij van de dertien jaar, die zijn eerste verblijf in Indië duurde, er bijna tien met reizen; zijn medische plichten in Batavia, Weltevreden, Buitenzorg en Djokjakarta namen hem slechts gedurende ruim drie jaar in beslag. Maar ook zijn krachtig lichaam is tegen een dergelijke inspanning niet vol- 
komen bestand; in Augustus 1848, verzwakt door de tropische hitte, waartegen hij meermalen in de koelte der bergen bescherming zocht, gaat hij met verlof, voorloopig voor drie jaar, later tot zeven jaar verlengd. Wel was dit verlof ,om gezondheidsredenen" toegestaan, maar Junghunn, die in zijn leven de woorden van Schiller: „Es ist der Geist, der sich den Körper baut" '), zoo volkomen bewaarheid heeft, was niet van zins dezen rusttijd voor rust te gebruiken. Hij heeft het in die dertien jaar verzamelde materiaal pas gedeeltelijk verwerkt en gepubliceerd; in Europa zet hij zijn onderzoekingen en beschrijvingen met kracht voort; reeds in 1850 verschijnt zijn grootste werk: "Java, deszelfs gedaante, bekleeding en inwendige structuur" " $)$, oorspronkelijk in het Duitsch geschreven, met hulp o. a. van De Vriese en Molkenboer vertaald en met gouvernementssubsidie uitgegeven. In 1853 volgde een, tweede verbeterde uitgave". Alle uitgeverspractijken en publicatieverwarring zullen wij terzijde laten; men kan hierover voldoende inlichtingen vinden in de volledige Junghunv-bibliographie ${ }^{3}$ ).

JunGHUHv's rustelooze natuur kan hem niet lang in de studeerkamer houden; reizen moet hij, landen zien, gebergten en flora's onderzoeken; ook zijn verloftijd wordt hiervoor gebruikt. Gansch Europa is eigenlijk nog te klein in omvang; vooral de Europeesche berglanden trekken hem met groote kracht: Alpen, Pyreneën, Kaukasus, die alle bezoekt hij; hier komt tot hem de herinnering aan zijn geliefde Java, dat hem altijd weer terugroept.

Tijdens Juxghuns's verlof wordt tot ontbinding van de

ז) Zie Max C. Р. Sснмidt, 1909. p. 76.

2) F. Junghunn, I $850-$ r854. Java, deszelfs gedaante, bekleeding en inwendige structuur. 4 dln. Amsterdam, 1850-1854.

Duitsche vertaling door J K. HassKarl. Leipzig, I852-I854.

3) Zie W. C. Muller, rgro. Junghuhn-Bibliographie. (Junghuhn-Gedenkbock, 1910. p. $309-356)$. p. $326-333$. 
F. W. JUNGHUHN.

Natuurkundige Commissie besloten; maar tevens werd bepaald, dat de leden Schwaner en Junghin op dezelfde wijze werkzaam konden blijven. Zoo bestond voor Junghuns het vooruitzicht, na afloop van zijn verlof naar Indië terug te keeren en zich opnieuw aan de bestudeering der talrijke vraagstukken op het gebied van Java's flora en geologie te wijden. Pas in Juli I 855 eindigde zijn verloftijd en begaf hij zich aan boord der „Minister Pahud" met Java als bestemming.

Maar Junghunn was tijdens zijn tweede verblijf in Indië niet meer de krachtige man van vroeger; bovendien werd hij na HASSKARL's vertrek ( 1856 ) belast met de inspectie der kinatuinen en daardoor genoodzaakt zijn zuiver-wetenschappelijk werk min of meer te verwaarloozen. Wel reist hij nog veel en brengt hij op zijn reizen nog een belangrijke verzameling planten bijeen, maar zijn tijd van productie is voorbij; na 1855 verschijnen van zijn hand alleen mededeelingen, jaarverslagen en strijdschriften met betrekking tot de kinacultuur. In de tweede helft van I86I is de groote Ferdinand von Richthofen eenigen tijd zijn gast. Langzamerhand worden de lichaamskrachten gesloopt; hij hoopt in Europa te herstellen, vraagt en verkrijgt daarom verlof, maar nog voor zijn vertrek uit Lembang overvalt hem een hevige leverziekte, die noodlottig worden zou.

In den vroegen morgen van 24 April 1864 kwam het einde van een krachtig leven.

JunGHuHn's eerste Indische periode is verreweg de meest vruchtbare geweest. Veelzijdig als weinig anderen, bezat JunghuHN een zeldzame gave om op betrekkelijk weinig gegevens juiste en logische redeneeringen te bouwen, maar vond toch zijn groote kracht in scherpe waarneming en objectieve feitenbeoordeeling. Van huis uit plantkundige, wordt vooral het gansch braakliggende gebied der plantengeographie zijn studievak; overal weet hij uit de meest weelderige planten- 
formatie één of meer kenmerkende vormen te kiezen; steeds slaagt hij er in, een juist beeld van den plantengroei te ontwerpen. Gewoonlijk vrij sober van stijl, wordt Juxghuns als hij zich laat gaan, als de machtige indruk der tropische natuur hem meesleept, welsprekend en warm van taal, weet hij zijn lezer een schilderij voor oogen te brengen, overweldigend als de natuur zelve. En toch vergeet hij daarbij nooit de strenge eischen, door de wetenschap gesteld, nooit fantaseert hij of kleurt zijn landschapsschildering te sterk; waarheid wordt door hem steeds, zoowel in zijn wetenschappelijk als in zijn persoonlijk leven, als het hoogste goed beschouwd. Kenmerkend zijn de woorden, die op den muur van Junghunv's laboratorium geschreven stonden: "Amicus Plato, sed magis amica veritas".

De beschrijving van den plantengroei op Java, door JunghunN in het eerste deel van zijn ,Java" ${ }^{\text {) }}$ gegeven, is tot grondslar greworden voor de moderne planten-geographische onderzoekingen, door tal van geleerden op Java gedaan. Door zijn onvermoeide reizen en trekken, was hij in staat de geheele flora van dit rijkste der Indische eilanden te overzien. „Indefessus hic naturae scrutator omnes propemodum Javae montes adscendit et solertissime pervestigavit, atque eo maxime meruit, quod altitudines supra maris aequor, quas singulae species in montium jugis tenent, accurate annotaverit atque ita exstruxerit phytogeographiae javanicae fundamenta" getuigt MiQuel ${ }^{2}$ ) van hem. Vooral voor de Preangerbergen, in het algemeen voor West-Java, is Junghurin's indeeling in plantengordels (zeespiegel2000 voet; $2000-4500$ voet; $4500-7500$ voet en $7500-10,000$ voet) doeltreffend gebleken; in Oost- en Midden-Java vond hij plaatsen, waar de plantengroei sterke afwijkingen vertoonde

ז) F. Junghumn, 1850. Java, I. p. 218-671.

2) F. A. W. Mrquel, 1855. Flora van Nederlandsch-Indië. Amsterdam, Utrecht-Leipzig, I855. III. Inleiding. p. VII. 
F. W. JUNGHUHN.

en niet in een dergelijk algemeen schema ondergebracht kon worden ${ }^{\mathrm{x}}$ ).

Met wetenschappelijke plantenbeschrijving heeft JunghunN zich weinig beziggehouden, zijn verzamelingen voor een deel berustend in 's Rijks Herbarium te Leiden, werden grootendeels door anderen bewerkt. Behalve een belangrijk aantal geschriften o. a. van Nees von Esenbeck, De Vriese, Miquel, Dozy, MolKENBOer en HASSKarL ${ }^{2}$ ), verscheen in de jaren i 85 I- I857 een belangrijk werk over JunghuHs's verzamelingen van Javaansche en Sumatraansche planten: „Plantae Junghunianae" ${ }^{3}$ ), om onbekende redenen onvoltooid gebleven. Wat er in dien tijd onbewerkt gebleven is, benevens het door Juxghurs tijdens zijn tweede Indische periode verzamelde, is door Koorders onderzocht, en in een viertal publicaties beschreven ${ }^{4}$ ).

Dat ook de voorgeschiedenis van Java's flora JunGHuHn's aandacht geboeid heeft, blijkt uit de rijke verzameling fossielen uit het tertiaire tijdvak, door hem op zijn reizen bijeengebracht en in Europa bewerkt door GöPPERT ${ }^{5}$ ), die zich op zeer nauw-

I) Zie voor verdere bijzonderheden: S. H. KOORders en J. F. Niermeyer, rgro. JUNGHUHN's verdiensten voor de plantengeographie van Java. (JunghuhnGedenkboek. 's Gravenhage, 1910. p. 241-266).

2) Zie F. Junghunn, 1850. Java, I. p. 179-198.

3) Plantae Junghuhnianae. Enumeratio plantarum, quas in insulis Java et Sumatra, detexit Fr. Junghumn. Leiden, 1851-1857. (4 afl. p. I-570). Medewerkers hieraan waren: W. H. DE Vriese, F. A. W. Miquel, J. H. Molkenboer, L. A. J. Burgersdij, J. K. Hasskarl, C. Benthali, A. Spring, A. J. de Bruyn, F. Dozy, L. H. Buse, C. Montagne, R. B. van den Bosch en C. M. van der SANDE Lacoste.

4) S. H. Koorders, r908-I910. Plantae Junghuhnianae ineditae. I-IV. (I, Versl. Gew. Verg. Wis- en Natuurk. Afd. Kon. Ak. Wet. XVII. p. r56-160; II. Ibidem. p. $780-782$; III. Ibidem. p. $948-955$; IV. Junghuhn-Gedenkboek, 1910. p. $151-198)$.

5) H. R. Göpert, I854. Die Tertiärflora auf der Insel Java, nach den Entdeckungen des Herrn FR. JunghuHN beschrieben und erörtert in ihren Verhältnisse zur Gesammtflora der Tertiärperiode. ('s Gravenhage, 1854). 
gezette wijze van deze taak gekweten heeft. Met het onderzoek van zijn verzameling dierlijke fossielen was JuxGHun minder gelukkig: Herklots, die de bewerking hiervan op zich genomen had, kon door herhaalde ernstige ongesteldheid niet meer publiceeren dan een deel der echinodermen-vondsten ${ }^{1}$ ); gelukkig echter heeft een Duitsch-Nederlandsch onderzoeker, de Leidsche Hoogleeraar Dr. K. MARTin, later (i879) HerkLots' taak overgenomen en de bewerking van JunghuHss belangrijke ontdekkingen tot een goed einde gebracht ${ }^{2}$ ).

Hoewel JunghuHN eigenlijk geen geoloog, maar botanicus was, waren toch zijn terreinbeschrijvingen, zijn landschapsschetsen, zijn teekeningen van profielen en zijn kaarten uitnemend verzorgd, zoodat ook in dit opzicht zijn "Java" een standaardwerk biijft van groote waarde. Op zuiver geologisch gebied is JuNGHun niet altijd gelukkig geweest in zijn onderzoek; toch heeft hij ook hier belangrijke ontdekkingen gedaan en wist hij ook op dit moeilijke gebied zijn eigen opvattingen met succes te verdedigen. "Vooral hoog is hem de verdienste aan te rekenen", getuigt Verbeek ${ }^{3}$ ) van Junghuns, ,dat hij optrad tegen de theorie der „Erhebungs-Kratere” bij de vulkanen, en hier heeft men voorzeker met een geologisch feit te doen. Hij bewees duidelijk, dat de vulkanische kegelbergen, door het uitwerpen van losse en vaste stoffen om een centrum, zichzelf successievelijk opbouwen, dat de helling der aschlagen en lavastroomen, van de kraters tot aan den voet der vulkanen, oorspronkelijk is en niet aan latere opheffingen is toe te schrijven,

2) J. A. Herklots, 1854. Fossiles de Java; Description de restes fossiles d'animaux des terrains tertiaires de lîle de Java, recueillis sur les lieux par M. Franz Junghuhn. Leide, 1844 .

$\left.{ }^{2}\right)$ K. Martin, 1879-1880. Die Tertiärschichte auf Java. Nach den Ent. deckungen von $F_{R}$. JUNGHUHN bearbeitet. Leiden, I879-I880.

3) R. D. M. Verbeek, I910. Junghuhn als geoloog. (Junghuhn-Gedenkboek, 1910. p. 105-I20). p. I19. 
F. W. JUNGHUHN.

en ook dat eene verheffing van den ondergrond daarbij geen rol speelt. Die theorie moge nu zeer verouderd schijnen, in Junghunn's tijd werd zij nog door veel geologen als juist aanaangenomen en zij werd gesteund door de autoriteit van een LEOPOLD von Buch!', Dat JunghuHn ook op geologisch gebied verdienstelijk werk heeft kunnen leveren, dankte hij voornamelijk aan zijn onbevangen oordeel over feiten, aan zijn vrij-zijn van alle bestaande theorieën, waardoor hij zonder vooringenomenheid tegenover de natuurvraagstukken te staan kwam.

Onwillekeurig komt men bij de beschouwing van een zoo grootsche figuur in ons Indisch natuuronderzoek, als die van Franz Wilheli Junghuhn, tot een vergelijking met den grootste onder zijn voorgangers, Rumphics. En dan blijken beide mannen in meer dan een opzicht overeenkomst te vertoonen: beiden gaven zich met al hun kracht en al hun willen aan de taak, die zij zichzelf hadden opgelegd, beiden kenden geen rust in het land, waarheen het lot hen gevoerd had, en waar de rijke, ongerepte natuur hun zooveel te zien en te overdenken gaf, dat hun geheele leven hieraan gewijd werd; beiden beschikten over een scherp waarnemingsvermogen, over een onbevangen blik op de juistheid van overgeleverde verhalen en op de waarde der ontdekte feiten. Maar daarnaast vinden wij ook punten van verschil. Rumputus leefde in een tijd van naief geloof, van bijna kinderlijke vereering voor de ontzagwekkende wonderen der schepping, zoodat hij meestal blijft staan bij een objectieve natuurbeschrijving, al laat hij zich wel eens tot theoretiseeren verleiden. Junghunn is een kind van zijn tijd, van de woelende en naar oplossing zoekende negentiende eeuw, voor wie geen feitenkennis maar feitenverklaring hoofdzaak is. RumpHits wonend op een eiland, ver van de ,beschaafde" wereld, rustig genietend van de mooie Ambonsche natuur; Junghumn, een man vol kracht en strijdlust, wien de gansche wereld te 
klein lijkt, zoeker naar waarheid in zijn wetenschap en in zijn wereldbeschouwing. Maar ondanks alle verschil in persoonlijkheid en in levensbeschouwing, beiden eerbiedwekkende mannen, wier naam in de geschiedenis der natuurwetenschap door alle ceuwen heen zal voortleven: Rumpuius de Indische Plinius, Junghunn de Humboldt van Java. 


\section{HOOFDSTUK VI.}

\section{Algemeene natuurwetenschap na $\mathbf{1 8 5 0 .}$}

Zooals goede vruchtboomen, in andere streken overgeplant, ook daar onder goede verzorging goede vruchten kunnen dragen, evenzoo zal een hier te lande welgewassen en krachtige tak van wetenschap bij liefderijke verpleging ook in onze tropen tot intensief leven en bloei gebracht kunnen worden. Zoo werden van alle langzamerhand zelfstandig geworden natuurwetenschappen stekken opgekweekt en naar Indië overgebracht. En evenals de tuinman zijn jonge boompjes vooral gedurende den eersten tijd met groote zorg beschermen moet, zoo moet ook degene, aan wien de verpleging der jonge wetenschap is toevertrouwd, maar al te waakzaam zijn, dat haar niet van een of andere zijde nadeel toegebracht wordt. Gelukkig echter waren voor deze verzorging meestal mannen aangewezen, die met alle kracht de soms vrij heftige tegenwerking ontwapenden en erin slaagden, hun kweekelingen tot gezonde forsche boomen te doen opgroeien. Zoo zien wij in Indië verrijzen een Magneto-meteorologisch Observatorium, een Landbouwscheikundige Onderzoekingsdienst, een uitstekend georganiseerd Mijnwezen, terwijl de reeds lang bestaande Plantentuin ook 
weer aan nieuwe inrichtingen het aanzijn schonk. Alleen de oude boom, de oorspronkelijke instelling van het algemeen natuuronderzoek, de Natuurkundige Commissie, was gestorven; in haar plaats kwamen gelukkig een aantal kleinere, oogenschijnlijk zonder eenige verwantschap, alle goede en rijke vruchten afwerpend.

De toenemende omvang der natuurwetenschappen was oorzaak, dat de onderzoekers niet meer het gansche gebied van natuuronderzoek konden beheerschen, dat ieder werker zich speciaal ging toeleggen op een of ander onderdeel. En dit had weer tengevolge, dat in het tijdvak na 1850 een samenvattende behandeling der uiteenloopende richtingen van onderzoek vrijwel onmogelijk was; dat wij dus den ontwikkelingsgang van iedere tak van wetenschap op zichzelf moeten beschouwen, zoodat in de volgende hoofdstukken het plantkundig onderzoek, de studie der dierenwereld, scheikundige arbeid, geologische ontdekkingen en meteorologisch werk alle een afzonderlijke bespreking zullen vinden.

Toch is ook in dezen tijd het verband tusschen die zelfstandige wetenschappen niet afwezig. Twee richtingen zijn er, waarin onderzoekers van verschillenden huize samengaan; twee gebieden, waarop zoölogen en botanici, geologen en chemici, meteorologen en oceanografen elkander ontmoeten kunnen en van elkanders hulp kunnen gebruik maken. Die gebieden zijn het wetenschappelijk vereenigingsleven, waaraan onverbreekbaar zijn verbonden de algemeen-natuurwetenschappelijke tijdschriften, en de expedities, onderzoekingsreizen soms van enkele personen, soms op grooter schaal georganiseerd door een of andere instelling.

Tot 1850 was het Bataviaasch Genootschap voor Kunsten en Wetenschappen het centrum van alle wetenschappelijk vereenigingsleven, zoodat de Verhandelingen tot dat jaar ook wel 
belangrijke mededeelingen op natuurwetenschappelijk gebied bevatten. Maar na I9 Juli I850 komt een andere vereeniging: de Natuurkundige Vereeniging te Batavia (na 20 Februari 1860 Koninklijke N. V.), een deel van het genootschapswerk overnemen; de oudere der twee zusters kon zich van dien dag af meer op taal- en volkenkundige studiën toeleggen; de Koninklijke Natuurkundige Vereeniging van Nederlandsch Indië werd het verkeersmiddelpunt van alle natuuronderzoekers.

Leidsman in deze nieuwe richting was de officier van gezondheid Dr. P. BleEker, een man van zeldzame toewijding aan zijn studie en van een enorme werkkracht, waarvan de lijst zijner geschriften achter zijn autobiografie, een 700-tal in de jaren I 846 - I 878 , een beeld geeft. BLEEkER's groote verdiensten zijn gelegen in zijn krachtigen aandrang tot wetenschappelijk leven; van huis uit zoöloog, werd hij ook op dit gebied een der meest vruchtbare werkers, maar toch is de invloed, dien hij uitoefende op algemeen natuurwetenschappelijk gebied van veel verder strekkende gevolgen geweest.

In een, vooral uit psychologisch oogpunt, belangrijk „Levensbericht van Pieter Bleeker, door hemzelven" "), vinden wij een uiteenzetting van zijn gansche leven, van zijn streven, oorspronkelijk alleen voor zijn wetenschap, later ook voor statistische oeconomie en sociale vraagstukken met betrekking tot Indië.

Een zeer eenvoudige omgeving was het, waarin Pieter Bleeker io Juli i8I9 geboren werd. De vader had een kleine zeilmakerij te Zaandam en moest trachten daarmee voor zijn groot gezin, waarvan echter slechts vier kinderen volwassen werden, het onderhoud te verdienen. Door hulp van een vriend zijner ouders werd PIETER apothekersleerling te Amsterdam,

I) P. Bleeker, i877. Levensbericht van Pieter Bleeker door hemzelven. Met een voorwoord van P. HARTING. (Jaarboek Kon. Ak. v. Wet. 1877. p. 5-159). 



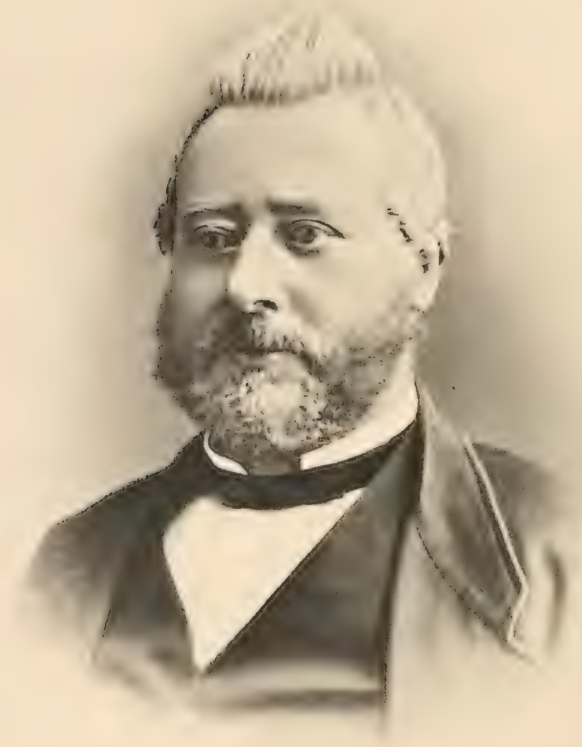

P. BLEEKER. 
daarna te Haarlem, waar hij in staat was, naast zijn werk de clinische school te bezoeken. Dat was in de jaren $1838-1840$. Maar ook dit bevredigde hem niet; TEYLER's rijke bibliotheek had voor hem veel meer verlokkends, dan de dorre medische colleges. Hij legde met zoo weinig mogelijk inspanning het examen af voor ,stedelijk heelmeester en plattelandsgeneeskundige" (1840) en verbond zich, na tweemaal getracht te hebben aan 'Temminck's museum geplaatst te worden, als officier van gezondheid bij het Indische leger. In Maart 1842 bereikte hij Batavia, waar hij terstond als adjudant aan den Chef van den geneeskundigen dienst werd toegevoegd. Spoedig na zijn aankomst begon hij den weinigen vrijen tijd, dien zijn bureauwerk hem liet, te gebruiken voor de organisatie van wat hij voor de bevordering van het natuurwetenschappelijk leven het meest noodzakelijk achtte: een Tijdschrift, uitsluitend gewijd aan natuur- en geneeskunde. Als resultaat van zijn werk verscheen in 1844 de eerste jaargang van het "Natuur- en Geneeskundig Archief van Nederlandsch-Indië". Wel waren hiervan slechts een viertal deelen verschenen, voor een groot deel gevuld met eigen werk, toen de ondernemende BLEEKER door overplaatsing naar Semarang genoodzaakt werd de uitgave te staken, maar toch was het in het geheel niet onvruchtbaar geweest: het was de voorlooper, de wegbereider voor de „Koninklijke Natuurkundige Vereeniging”, en haar nog steeds bloeiend, in reeds meer dan zeventig deelen verschenen „Natuurkundig Tijdschrift voor Nederlandsch Indië”.

Maar door zijn vriendschap met W. R. Baron van Hoëveld, die omstreeks 1846 wegens zijn vooruitstrevendheid de ongenade der regeering op zich had geladen, en door een paar statistische bijdragen in zijn "Archief", was ook BleEkER in I 847 niet langer een persona grata; tegen den zin van zijn chef, Dr. W. Bosch, werd Bleeker van zijn adjudantschap ontheven 
ALGEMEENE NATUURIVTENSCHAP NA I850.

en naar Semarang overgeplaatst. Deze jaren, vooral r 848 , waren weinig vruchtbaar voor zijn zoölogisch werk; de medische studiën, waartoe zijn praktijk hem dwong, waren oorzaak van het verschijnen eener monographie over de dysenterie, een belangrijke arbeid, die hem te Utrecht het doctoraat honoris causa bezorgde, een waardigheid, hem reeds vroeger door Leidens Senaat verleend voor zijn eerste geneeskundig-topografische bijdragen in het Archief. In I 848 schreef hij slechts één zoölogisch artikel, nauwelijks 8 bladzijden lang, maar van groote gevolgen. Dit artikel verscheen teSingapo re in het ,Journal of the Indian Archipelago and Eastern Asia". Een zeer scherp gesteld verwijt aan den G.-G. Rcchussen, waarin hij o. a. zeide: ,The year I 846 will be noted in the history of Netherlands India as the last year of the decennium of scientific activity", was aanleiding, dat de G.-G. hem wilde dwingen, deze woorden terug te nemen, en na BlEEkER's weigering hem wilde ontslaan. Maar dank zij de standvastigheid van den Legercommandant werd BleEker niet ontslagen. Wel werd hij tijdens de tweede Bali-expeditie naar Soerabaja verplaatst en vandaar naar Ambarawa. In $\mathbf{1} 849$, bij de oprichting van de geneeskundige school voor inlanders, zette zijn vroegere chef, Dr. Bosch, door, dat aan Bleeker de leiding gegeven werd. Zoo kwam hij in dat jaar weer naar Batavia, waar hij zijn verderen Indischen tijd doorbracht.

In deze jaren was het, dat BleEker de stichting der Natuurkundige Vereeniging bewerkte; niet tegenover, maar naast het Bataviaasch Genootschap moest de nieuwe instelling werkzaam zijn; ten bewijze hiervan het feit, dat BLEEkER zelf in I 853 nog secretaris van het Genootschap was en als zoodanig bij gelegenheid van de verschijning van het $25^{\mathrm{e}}$ deel der Verhandelingen, een geschiedenis van het Genootschap samengesteld heeft (zie blz. 77, voetnoot I.) En dat BleEker goed gezien 
heeft, blijkt uit het bloeiende vereenigingsleven, waarvan beide instellingen thans nog getuigen.

De onmogelijkheid, een grootsch opgezet werk over de vischfauna van Ned. Indië, zijn "Atlas ichthyologique”, in Indië zelf te doen drukken, deed hem in 1860 besluiten pensioen te vragen, om zich in Nederland te gaan vestigen en daar zijn studiën te blijven voortzetten. Behalve voor zijn wetenschappelijk werk vond BleEker hier nog lust en gelegenheid in staatsaangelegenheden de belangen van Indië voor te staan; hij nam de redactie van het „Tijdschrift voor Ned.-Indië" van VAN HoËvell over en werd in 1864 benoemd tot Staatsraad in buitengewonen dienst, wel een bewijs, hoezeer de liberale regeering van THORBECKE zijn bekwame adviezen wist te waardeeren. En een tijdlang verheugde BlEEkER zich in een groote populariteit, n.l. toen in 1860 hier te lande een cholera-epidemie uitbrak en hij in een brochure, binnen een maand twaalfmaal herdrukt, het Indische cholera-mixtuur publiceerde, dat hier spoedig den naam „BLeEkers drank” kreeg. Talrijke malen poogde hij ook het wetenschappelijk leven in ons land te versterken, evenals hij dit in Indië gedaan had, trachtte hij de werkzaamheid van wetenschappelijke instellingen, als de Koninklijke Akademie van Wetenschappen, het Haagsche Koninklijke Zoölogisch Botanisch Genootschap, meer intensief te maken, maar ook hier bleek zijn geest te voortvarend voor de behoudende Nederlanders. Het op zijn aandrang opgerichte ,Nederlandsch Tijdschrift voor Dierkunde" moest in 1873 wegens gebrek aan krachtige medewerking, ophouden te bestaan. En intusschen had hij steeds meer nieuwe moeilijkheden te overwinnen, vooral van finantieelen aard, bij de uitgave van zijn "Atlas". Hij slaagde er niet in, zijn monumentaal werk te voltooien; negen deelen, waarvan het negende incompleet, ongeveer vier vijfde van het geheel, zijn verschenen; de 
rest is als bouwstof achtergebleven. Op 24 Januari 1878 werd dit veel bewogen, door krachtigen drang geleide, leven afgesneden.

Reizen, en in sterke mate reizen in tropische streken, liggen niet binnen ieders bereik. Aan weinige uitverkorenen is het gegeven, volkomen zelfstandig een wetenschappelijken onderzoekingstocht te ondernemen. Als een gelukkige omstandigheid mogen wij het dus beschouwen, dat in dezen tijd enkele vereenigingen zich op het onderzoek der tropen gaan toeleggen; de sedert 1850 bestaande Koninklijke Natuurkundige Vereeniging voor Nederlandsch.Indië, het in 1873 opgerichte Nederlandsch Aardrijkskundig Genootschap (na I 888 Koninklijk N.A.G.) en de „Maatschappij ter bevordering van het Natuurkundig Onderzoek der Nederlandsche Koloniën", om de lange naam eerst wel eens als "VALEnTyN-maatschappij" aangeduid, thans als gedachtenis aan haar stichters ook wel ,TREUB-SERrurierMaatschappij" of kortweg "TREUB-Maatschappij" genoemd.

De Koninklijke Natuurkundige Vereeniging had in 1850 de natuurwetenschappelijke belangen van het Bataviaasch Genootschap overgenomen; het Aardrijkskundig Genootschap kan thans terugzien op een veertigjarig bestaan, waarin ook de kennis van Indië's fauna en flora van de door het Genootschap uitgeruste expedities veel voordeel getrokken heeft.

Het initiatief voor de ,Maatschappij ter bevordering van het Natuurkundig Onderzoek der Nederlandsche Koloniën" is te danken aan den ruimen en practischen blik van TREuB, die tijdens zijn eerste Europeesch verlof als directeur van 's Lands Plantentuin (1887-I888) van de herlevende belangstelling in onze tropen gebruik maakte voor de organisatie van een "Commissie tot Bevordering van het Natuurkundig Onderzoek der Nederlandsche Koloniën", een commissie van geleerden, die niet over fondsen beschikte, maar aan onderzoekers, die een studiereis wilden gaan maken, zedelijken steun verleende bij onderhande- 
lingen met de regeering. In Indie richtte TREuB na zijn terugkeer een „Indisch Comité van Wetenschappelijk Onderzoek" op, met ongeveer hetzelfde doel; hij zelf werd de eerste voorzitter daarvan. De werkkring der Commissie werd belangrijk uitgebreid door Dr. L. Serrurier, directeur van 's Rijks ethnographisch museum, die erin slaagde (I 890 ) naast de Commissie een Maatschappij te stichten, beschikkend over een door "Directeuren” bijeengebracht kapitaal, waaruit de onkosten van wetenschappelijke expedities bestreden konden worden. De samenwerking van Commissie, Comité en Maatschappij is van groote vruchtbaarheid geweest, zoodat verschillende belangrijke onderzoekingstochten gevolgd zijn. De Commissie is ten slotte geheel in de Maatschappij opgenomen.

Van regeeringswege ontbrak in het eerste gedeelte van het nu te bespreken tijdvak vrijwel alle initiatief voor floristisch of faunistisch onderzoek; meldde daarentegen een reiziger zich om hulp voor onderzoekingen aan, dan werd meestal aan deze verzoeken gevolg gegeven. Maar het ondernemen van zulke reizen werd volkomen aan particulieren overgelaten, met het gevolg, dat men in de periode, die we nu behandelen, nog minder stelselmatig te werk ging, dan tijdens het bestaan der Indische Commissie. Wel is de opmerking van VETH $^{\mathrm{I}}$ ): ,nu voor een groot deel van Insulinde de algemeene trekken van flora en fauna bekend waren, nu kon het voortgezet onderzoek langs anderen weg op meer doeltreffende en zeker op veel minder kostbare wijze worden verkregen", grootendeels juist, maar daartegenover betoonde de regeering in dezen tijd een zoodanige slapte en laksheid in het bevorderen van het natuurkundig onderzoek, dat hiervoor geen verdediging te vinden is. Een belangrijke fout was het gebrek aan samenwerking

3) H. J. VETh 1879. p. I23. 
ALGEMEENE NATUURIVETENSCHAP NA 1850.

tusschen Nederlandsche en Indische bestuurderen zeker, maar grooter fout lag m. i. in de energiedoodende onverschilligheid voor het onderzoek en in de achterdocht, die aan sommige uitstekende onderzoekers ten deel viel.

In 1855 werd door den toenmaligen Gouverneur-Generaal Duymaer van Twist een reis naar de Molukken en de Minahassa gemaakt, op welken tocht hij door BLEEkER vergezeld werd. Als resultaat van deze onderzoekingsreis verscheen BleEkERs reisverhaal ${ }^{\mathrm{I}}$ ), een uitvoerig werk, waarvan WARBURG $^{2}$ ) in 1902 getuigt: „Die Reiseergebnisse legen ein glänzendes Zeugniss ab für die grosse Begabung des Verfassers". Zooals te verwachten was, is dit reisverhaal vooral uit zoölogisch oogpunt van beteekenis; belangrijk zijn echter ook BLEEKERs statistische en kultuurhistorische mededeelingen over handels- en kultuurplanten.

Van groote wetenschappelijke gevolgen was het verblijf van een Engelschman in onzen Archipel in dezen tijd: AlfreI) Russel Wallace, tijdgenoot en strijdmakker van Darivin. Onder ongunstige omstandigheden opgegroeid, had WALLACE alles aan zichzelf te danken: begonnen als leerjongen in een timmermanswerkplaats, had hij op zijn $25 \mathrm{e}$ jaar reeds verschillende beroepen: landmeter, horlogemaker, schoolmeester achter den rug, toen hij op goed geluk, vergezeld door BATEs, naar Zuid-Amerika trok om daar de omgeving van Pará en de Amazonerivier wetenschappelijk te onderzoeken ( 1848 - I852). Op de terugreis verloor hij zijn geheele verzameling, maar kon van de verzekeringssom ruim een jaar te Londen leven, om daar zijn reiservaringen te boek te stellen.

I) P. Bleeker, 1857. Reis door de Minahassa en den Molukschen Archipel, gedaan in de maanden September en October 1855 in het gevolg van den gouverneur.generaal Mr. A. J. Duymaer van Twist. 2 dln. Batavia, i857.

$\Rightarrow$ O. WARBurG, I902. Die botanische Erforschung der Molukken seit Ruirps Zeiten. (Rumphius-Gedenkboek, 1902. p. 63-78). p. 69. 


\section{ALGEMEENE NATUURWETENSCHAP NA 1850.}

De reislust was in hem aangewakkerd: het volgend jaar (IS54) ging hij op kosten der Engelsche regeering, die hem eerst vrijen overtocht op een oorlogsschip beloofd had, naar Singapore en begon daar voor eigen rekening zijn achtjarigen tocht door den Maleischen Archipel, eerst in Malakka, daarna op Borneo, waar hij reeds een eerste artikel over het ontstaan van nieuwe soorten ${ }^{\mathrm{I}}$ ) schrijft. Vervolgens bereist hij Celebes, het land, dat hem in het bijzonder aantrekt, omdat het nog zoo geheel ,terra incognita" is en naar zijn meening, die hij in een brief aan BATEs te kennen geeft, zoölogisch misschien belangrijk is, omdat Malakka, Borneo, Sumatra en Java eigenlijk slechts één zoölogisch gebied zouden vormen. Hier vinden we een eerste aanduiding van wat uit zijn verdere onderzoekingen tot "lijn van WALLACE" geworden is, daarmee het grootste van alle zoölogische problemen uit onzen Indischen Archipel, dat der zoögeographie, treffend. Van Celebes trekt WALL.ıcE verder door den Archipel: o.a. bezoekt hij de Molukken, Timor, Bali en Lombok, Java en Sumatra.

$\mathrm{Na}$ zijn eerste artikel over het ontstaan van nieuwe soorten, waarin hij zich overtuigd aanhanger van soortsveranderlijkheid toont, laat WALLACE in 1858 een tweede volgen, geschreven op Ternate, terwijl een hevige malaria-aanval hem dwong, niets te doen, dan te denken. Toen kwam hem plotseling de gedachte aan Malthus' „Essay on the principle of population” te binnen, een werk, dat hij twaalf jaar tevoren gelezen had en dat hem nu op het spoor bracht van het, hoe ontstaan nieuwe soorten". Zijn artikel ${ }^{2}$ ) daarover zond hij aan D.siwn, die op aandrang van Lrell en HonKer ook zelf een korte uiteenzetting

I) A. R. WALLACE, I855. On the law which has regulated the Introduction of New Species. (Ann. and Mag. Nat. Hist. I855).

2) A. R. Waltaci, IS5S. On the tendency of varieties to depart indefinitely from the original type. (Journ. Linn. Soc. Zoöl. III. p. 53-62). 
van zijn eigen theorie schreef, zoodat de beide verhandelingen samen (I Juli $\mathrm{I}_{5} \mathrm{~S}$ ) in de vergadering van de Linnean Society voorgelezen konden worden. In Engeland teruggekeerd (1862) begon WALLACE zijn reisverhaal te bewerken, dat tot een belangrijk werk, zijn meest populaire "The Malay Archipelago" is geworden ${ }^{x}$ ).

Dan volgde in 1857 de Oostenrijksche expeditie met de „Novara” onder leiding van B. von WüllerstorF-Urbair, waaraan KarL von Scherzer en Georg von Frauenfej, deelnamen. Het doel was een reis om de wereld; de tocht werd echter, nadat het grootste deel afgelegd was en onze OostIndische koloniën bezocht waren, wegens de ernstige politieke omstandigheden, waarin Oostenrijk in $\mathrm{s} 859$ verkeerde, in $\mathrm{Val}$ paraiso afgebroken, vanwaar zoo spoedig mogelijk huiswaarts gezeild werd. Behalve een populaire reisbeschrijving door VoN Scherzer, verscheen over deze reis een standaardwerk ${ }^{2}$ ), waaraan door tal van zoölogische, botanische en geologische specialisten meegewerkt werd.

Door regeeringsbemoeiing werden in dezen tijd reizen gemaakt door Dr. H. A. Bernstein, C. B. H. von Rosenberg en D. S. Hoedt.

r) A. K. Wallace, 1864. The Malay Archipelago. The Land of the OrangUtan and The Bird of Paradise. (London. I uitg. 1S64). Nederlandsche vertaling door prof. P. J Veth. (Amsterdam 1870-I $87 \mathrm{I}$ ).

$\left.{ }^{2}\right)$ Reise der oesterreichischen Fregatte Novara um die Erde in den Jahren r857, 1858, r859 unter dem Befehl des Commodore B. voN Wüllerstorf URbair. Wien, I86i-I875. Beschreibender Teil von Dr. K. von Scherzer, z Bde gr. $8^{\circ}$. Het wetenschappelijk gedeelte, in $18 \mathrm{kwartodeelen}$ werd bewerkt voor zoover den plantengroei betreft door A. Grunow, J. Krempelhuber, H. W: Reichardt, G. Mettenius, J. Milde en E. Fenzl, het geologisch werk door F. v. Hochstetter, M. Hoernes, F. v. Hauer; termijl de zoölogie door J. Zelebor, A. v. Pelzeln, F Steindachner, R. Kner, L. Redtenacher, H. de Saussure, J Sichel, G. L. Mayr, T. Brauer, J. R. Schiner, C. Feliner, R. Felder, A. R. Rogenhofer, C. Heller, E. Grebe en G. von Frauevitild bewerkt werd. 
Dr. H. A. Beristein was geneesheer aan het gezondheidsetablissement te Gadok bij Buitenzorg, en kreeg door bemiddeling van Schlegel, die Temminck als directeur van het Leidsche museum opgevolgd was, steun van de regeering voor een door hem ontworpen reis naar Nieuw-Guinea en Halmaheira, en wel een vaste maandelijksche toelage, benevens reis-, verblijf- en uitrustingskosten. In Nov. 1860 vertrok hij van Batavia naar Ternate en Batjan, waar hij een half jaar voor het Leidsche museum verzamelde, daarna naar Halmaheira, Morotai, de Obieilanden, Gebeh, Dammer enz. Toen hij zich (voorjaar 1865) eindelijk op reis begaf naar het hoofddoel zijner tochten, NieuwGuinea, overleed hij onderweg. Bernstern was ongetwijfeld een zeer bekwaam man, die echter naar verhouding van zijn gaven niet voldoende heeft gewerkt. Slechts enkele ,,voorloopige mededeelingen nopens reizen in den Molukschen Archipel"' ${ }^{\text {I }}$ ) verschenen van zijn hand; de waarschijnlijk belangwekkende brieven aan Schlegel, den nieuwen directeur van het Leidsche museum, zijn nooit uitgegeven, wel daarentegen zijn dagboek, verzorgd door S. C. J. W. van Musschenbroek ${ }^{2}$ ).

Het werk van Rosenberg en Hoedt was ook niet zonder beteekenis; het verschafte vrij veel materiaal aan het RijksMuseum, bouwstoffen voor BLEekers onderzoekingen en voor publicaties van Schlegel en Syellen van Vollenhoven.

De „Preussische Expedition nach Ost-Asiën” (1860-62) was een zeer succesvolle tocht; de zoölogische resultaten werden door E. vox MARTExs verwerkt tot een standaardwerk ${ }^{3}$ ), in vele

;) Tïdschr Ind. Taal-, Land. en Volkenk. XVI. I864. p. 399-495 en XVII. IS69. p. 79-109.

f S: C. J. W. van Musschenbroek. I $88_{3}$. Dagloek van H. A. Bernstein's laatste reis, van Ternate naar Nieuw-Guinea, Salawati en Batante, 17 ()ct. 186.4In April rSú5. (Bijdr. Taal-. Land-en Volk. v. N.-I., $4^{\mathrm{e}}$ r. VII, ISS3. p. I-io5).

5) E. YON MARTExs, 1S67-1876. Die Preussische Expedition nach (Ost-Asiën. Zoölogischer Teil. 2 Bde. (Berlin, Band I, IS76; Band II, 1867). 
opzichten één der beste zoölogische geschriften over onzen Archipel.

Een Amerikaansch hoogleeraar, A. S. BICKMore ${ }^{x}$ ), bereisde van 1865-1S66 ons Indië, waarbij hij zich voornamelijk tot taak stelde, de door Rumphius beschreven schelpen in de Molukken weder te verzamelen, en zoodoende met de Rariteitkamer ten grondslag een uitvoerige studie der schelpenfauna in de Molukken te maken.

In het bijzonder waren het drie Italianen G. Doria, O. BECCARI en L. M. D'Albertis, die zich in dezen tijd groote verdienste verworven hebben ten opzichte van de faunistische en floristische kennis van den ganschen Archipel (I865-1867); hun verzamelingen kwamen aan het Museum van Natuurlijke Historie te Genua. Doria was voornamelijk zoöloog; Beccari verzorgde het verzamelde botanische materiaal. BeCCARI's "Nelle foreste di Borneo" ") is een van de meest boeiende reisverhalen, die ooit over Indië geschreven zijn; zijn "Malesia" "3) een prachtig standaardwerk over onzen rijken Archipel.

Verder verdienen nog vermelding de tochten van A. B. Meyer (1870-1873), die door zijn studiën op Celebes in staat was, samenwerkend met WigGLEsworTh ${ }^{4}$ ), een uitnemend boek over de vogelfauna van dit belangwekkend eiland uit te geven en van Miklucho-Maclay (1872-i878), die vooral Nieuw-Guinea bezocht.

De eerste expeditie, voornamelijk met diepzee-onderzoek als doel uitgerust, was de grootsche Challenger-expeditie (1872-

r) A. S. Bicknore, I 668 . Travels in the East-Indian Archipelago.(London, 1868),

$\Rightarrow$ O. BECCARI, I902. Nelle foreste di Borneo; viaggi e richerche di un naturalista. (Firenze, J902).

3) O BeccarI, I877-I89o. Malesia, Raccolta di osservazione botaniche intorno alle piante dell' archipelago indo-malese e papuana. I.-III. (Genova, 1877-1890).

4) A. B. Mever and L. W. Wigglesworth, i 898 . 'The birds of Celebes and the neighbouring islands. (Berlin, I898). 2 vol. 
I 876). De Challenger bezocht alleen het oostelijk deel van onzen Archipel (Banda-Zee, Arafura-Zee); de wetenschappelijke leiding was in handen van prof. C. Wrville Trouson, bijgestaan door John Murray, H. N. Moseley en R. yox WillearuesSim. Behalve het bewonderenswaardige Challenger-report ${ }^{2}$ ), verscheen over dezen tocht een populair reisverhaal van de hand van Moseley ${ }^{2}$ ).

Daarna begon ook ons land zijn roeping op dit gebied te gevoelen; het Aardrijkskundig Genootschap rustte de eerste Nederlandsche expeditie uit, die voorbereid werd door den oud-Kolonel W. F. VersteEc; en die voorlooper zou worden van een aantal andere, sommige met schitterende resultaten, andere minder succesvol. De Midden-Sumatra-Expeditie (Februari I877-Februari I879) stond onder leiding van luitenant ter zee Schociw Sintvoort, terwijl deelnemers waren D. D. Vetif, A. L. va. Hisseit en J. F. Syelleman. De leider stierf onderweg; de zoöloog Snellemax moest in 1878 om finantieele redenen teruggeroepen worden, waarna VAN HAssELT voor het verzamelen van zoölogisch en botanisch materiaal zorgde. Een groot werk ${ }^{3}$ ), waarvan de uitgave verzorgd werd door prof. P. J. Vetir, bevat o. a. twee deelen gewijd aan de zoölogische

s) Report on the Scientific Results of the Voyage of H. M. S. Challenger, during the years $1872-1876$, under the Command of Captain Georte S NARES and the late Captain F. T. Thomson, prepared under the superintendence of the late Sir C. Wyville Thouson and now of John Murral. 50 vol. $t$ I. Narrative. (3 vols.); II. Physics and Chemistry. (2 vols.); III. Deep-Sea deposits. (I vol.); IV. Botany. (2 vols.); V. Zoology. (to vols.); VI. Summary. (2 vols.) (London, I880-I895).

2) H. N. Mosticy, IS79. Notes by a naturalist on the Challenger being an account of various observations made during the voyage of H. M. S. Challenger round the world, in the years $1872-1876$. London, 1879.

3) Midden-Sumatra. Reizen en onderzoekingen der Sumatra-expeditie, uitgerust door het Aardrijkskundig Genootschap. $1877-1879$. (Leiden, 1881-18u2. $4 d \ln$. in $5 \mathrm{bdn}$ ). 
resultaten, waaraan door tal van specialisten: A. A. W. Hubrecit, M. Schepman, J. G. de Man, H. Albarda, C. Ritsemia Czn, A. de Bormans, P. C. T. Snellex, F. M. v. D. Wulf, G. L. Mayr, A. W. M. van Hasselt en R. Horst meegewerkt werd, en een deel botanie, bewerkt door A. L. vax Hasselt en J. G. Boerlage, met hulp van W. F. R. Suringar, C. A. J. A. Oudemans, C. M. v. D. Sande Lacoste, H. F. Jonkman en D. de Loos.

In dezen tijd, omstreeks 1880 , vallen ook de reizen van den Engelschman H. O. Forbes ${ }^{x}$ ) die de eilanden Ambon, TimorLaut, Timor en Boeroe bezocht $(1878-1883)$ en van den Zweedschen onderzoeker $\mathrm{C}$. Bock, die met regeeringssteun een tocht door Borneo, van Koetei naar Bandjermasin, maakte. Een paar jaar later ging Dr. Bock in opdracht van de Berlijnsche Akademie van Wetenschappen in de Java-zee en de Moluksche zee rifdieren verzamelen (I 885); de Russische hoogleeraar A. A. Korotneff bezocht het westelijk deel van den Archipel; Sidney Hicksox verzamelde land- en zeedieren in Noord-Celebes, de Sangi- en Talaut-eilanden (I885-I886), terwijl E. Modiglinni een begin maakte met zijn Indische studiereizen door allereerst de Westkust van Sumatra en Nias te bezoeken (1886), om dan later de Bataklanden (1891) en de Mentawei-eilanden (1894) als onderzoekingsterrein te kiezen. Van beteekenis is nog Guillemards "Cruise of the Marchesa" $(\mathrm{I} 882-\mathrm{I} 884)^{2}$ ), waarin, vooral in het tweede gedeelte, belangrijke mededeelingen over ons Indië voorkomen.

De herleefde belangstelling in het natuuronderzoek onzer Koloniën zou blijken van blijvenden aard te zijn. En het is

э) H. O. Forbes, 1885. A naturalist's wanderings in te Eastern Archipelago, a narrative of travel and exploration from 1878 to 1883 . London, $\mathrm{ISS}_{5}$.

2) F. H. H. Guillemard, 1886. The cruise of the Marchesa to Kamschatka and New Guinea with notices of Formosa, Liu-Kiu and various islands of the Malay Archipelago. London, 1886. 2 vols. 
vooral de in het voorjaar van 1887 ontworpen, in de jaren I888-I889 uitgevoerde reis van den Amsterdamschen hoogleeraar Dr. Max Weber en Mevrouw Dr. A. Werer-Van Bosse, een tocht naar de Padangsche Bovenlanden, naar West-Java en naar Zuid-Celebes en Flores, die niet alleen om zijn directe resultaten, het verzamelde zoölogisch materiaal, maar vooral om de indirecte gevolgen, de prikkel tot navolging, van beteekenis werd. De belangrijke studies, vooral op het gebied van zoetwaterfauna en invertebraten, door verschillende medewerkers neergelegd in een grootsch vierdeelig werk ${ }^{\mathrm{x}}$ ), bewijzen wel hoeveel een enkel onderzoeker in een aan fauna rijk land als Indië, in betrekkelijk korten tijd kan tot stand brengen.

Intusschen had ook de Nederlandsche regeering haar goeden wil getoond, door in 1883 een som van $f$ I0,000.- op de begrooting uit te trekken, teneinde daaruit onderzoekingsreizen van Nederlanders te steunen, voorloopig een papieren maatregel, die weinig resultaat had. Door gebrek aan overeenstemming tusschen Regeering en Aardrijkskundig Genootschap kwam in het begin geen der ontworpen plannen tot uitvoering, totdat er meer voortgang kwam door de besluiten tot een expeditie naar de Kei-eilanden en een tocht naar de Kleine Soendaeilanden. De voorgenomen reis van MAX WEBER was nu een gereede aanleiding, samenwerking te zoeken, met het gevolg, dat de door het Kon. Ned. Aardr. Gen. gesteunde onderzoekingstocht van Prof. Dr. A. Wicmmaxi: (IS88-1890) 2) naar Flores, Timor, Rotti en enkele andere eilanden, door W Wrer, die zich reeds in Indië bevond, kon voorbereid worden en dat

1) Max Wener, 1800-1907. Zoölogische Ergebnisse einer Reise in Niederländisch-Ost-Indiën. 4 dln. (Leiden, 1890-1907).

2) A. Wichmann, 1890-1S92. Bericht uiber eine im Jahre $1885-1889$ in Auftrage der Niederl. Geogr. Gesellsch ausgefuhrte Reise nach dem Indischen Archipel. (Tïdschr. Kon. Ned. Aardr. Gen. $2^{\mathrm{c}}$ serie. VII, IS90. p. 907-094; VIII, 1891. p. 188-293 en IX, 1892. p. 161-276). 
voor zoover het Flores betrof, IVELER's en Wicmuanv's reizen konden samenvallen. Het voornaamste doel, waarvoor deze expeditie van Wicmusy werd uitgerust, was het geologisch onderzoek der bezochte eilanden; echter werd ook zoölogisch materiaal verzameld. Voorts werd met hulp van het K. N. A. G. door Dr. H. F. C. TEN KATE een tocht ondernomen naar de Timorgroep en Polynesië ${ }^{x}$ ), waaraan ook belangrijke faunis. tische waarnemingen te danken zijn, terwijl de Kei-eilanden het doel eener kleine expeditie waren, voor een deel bekostigd door A. LAxgey, waaraan deelgenomen werd door R. Postiumes Neves, reeds spoedig wegens ziekte teruggekeerd en vervangen door H. O. W. Planten en C. J. M. Wertheim. De verslagen dezer succesvolle expeditie verschenen in het Tijdschrift K. N. A. G., en later tot een bundel ${ }^{2}$ ) vereenigd, terwijl de geologische verzameling door Prof. MARTIx bewerkt werd ${ }^{3}$ ).

De mooie resultaten, door deze verschillende expedities verkregen, waren indirect ook te danken aan Dr. C. P. SLurter, die toentertijd een leeraarswerkkring bij het middelbaar onderwijs te Batavia vervulde, bovendien conservator was aan het Museum van de Koninklijke Natuurkundige Vereeniging en een uitstekende helper en raadgever was voor allen, die in dezen tijd onderzoekingstochten in onzen Archipel ondernamen.

$\mathrm{Na}$ de totstandkoming van TREUB's Commissie (7 Januari 1888) en de omzetting hiervan in de ,Maatschappij" werd ook van

I) H. F. C. TEN KATE, 1894. Verslag eener reis in de Timorgroep en Polynesië. (Tijdschr. Kon. Ned. Aardr. Gen. $2^{e}$ serie XI, 1S94. p. 195-24(), 333-3()0, $54 \mathrm{I}-638,659-700,765-8 \mathrm{I} 8,8$ I9 -822 . Ook afzonderlijk 3 I I pp.).

$\Rightarrow$ H. O. W. Plantên en C. J. M. IVertheim, I892-1893. Verslagen van de wetenschappelijke opnemingen en onderzoekingen op de Key-eilanden, gedurende de jaren 1889-r890, met inleiding van prof. C. M. KaN. (Tijdschr. Kon. Ned. Aardr. Gen. $2^{\text {e }}$ serie IX, 1892 en X, 1893 . Ook afzonderlijk).

3) K. Martin, 1890. Die Kei-Inseln. (Tijdschr. Kon. Ned. Aardr. Gen. ze serie VII, I890. p. $24 \mathrm{I}-280$ ). 
die zijde, niet alleen finantieele, maar vooral moreele steun verleend aan enkele onderzoekers: Prof. A. A. W. Hubrecht, die op uitnoodiging van de Koninklijke Natuurkundige Vereeniging met een regeeringssubsidie in I890-9 I Indië bereisde, vooral met het doel embryologisch materiaal te verzamelen en Dr. J. F. van Bemielen, thans hoogleeraar te Groningen, die eerst aan de West-Javaansche kust en in Deli zoölogische collecties bijeenbracht, en later (I89I) deelnemer werd aan de YZERMAN-expeditie, uitgerust met het doel de mogelijkheid van spoorwegbouw dwars door Sumatra na te gaan, een expeditie, waaraan ook de houtvester Dr. S. H. Koorders deelnam, maar die door de snelheid van bewegen uit natuurhistorisch oogpunt niet het verwachte resultaat gehad heeft ${ }^{\mathrm{x}}$ ).

Een periode van krachtig leven in de Trecb-SerrurierMaatschappij begon met de uitrusting van de eerste der drie Borneo-expedities (1893-1895), de drie tochten, aan welker voorbereiding TReub zelf zoo'n werkzaam aandeel had. Deelnemers aan deze eerste reis waren Prof. G. A. F. Molengraaff voor geologie, Dr. J. BütтाкоғEr, directeur der Rotterdamsche Diergaarde, voor zoölogie, Dr. H. HALl.IEr, assistent aan 's Lands Plantentuin, voor plantkunde, en Dr. A. W. Niecwenilis, tegenwoordig hoogleeraar te Leiden, als officier van gezondheid. Hoewel de expeditie door in de binnenlanden heerschende onrust niet het beoogde doel, doorkruising van Borneo, bereikte, waren haar wetenschappelijke resultaten geenszins gering.

Een nieuwe expeditie had onder gunstiger omstandigheden plaats (I896-1897); leider was Dr. A. W. Niecwexulis, terwijl de Duitsche graaf $F$. vox Berchthold voor het verzamelen van

3) J. F. van Bemmelen, 1895. Dwars door Sumatra. Tocht van Padang naar Siak onder leiding van den hoofdingenieur der Staatsspoorwegen J. W. IJzEranas, beschreven door de leden der expeditie J W. IJZFinan, J. F. VAN liemmelen. S. H. Koorders en L. A. Baknuis (Haarlem-Batavia, 1S(5)5). 
zoölogisch materiaal zorgde. Ongeveer een jaar duurde de tocht: in Juli 1896 van Poetoes Sibau (boven-Kapoeas) vertrokken, kwamen de onderzoekers in het midden van 1897 in Samarinda aan. $\mathrm{Om}$ van de op deze reis verkregen aanraking met de Dajaks zooveel mogelijk partij te trekken, ging Dr. Nieuwenhurs ingevolge opdracht van de Nederlandsch-Indische Regeering voor de derde maal het binnenland van Borneo in en bereikte ook thans zijn doel. Op deze derde expeditie werd hij niet door een zoöloog vergezeld; bijgestaan door een inlandschen helper, slaagde hij er toch in mooie verzamelingen bijeen te brengen, die zich thans evenals al het zoölogisch materiaal der vroegere Borneo-expedities, in het Leidsche Museum bevinden en daar bewerkt zijn. Van de hoeveelheid arbeid, door deze drie expedities verricht, geven MolengraffF's en Nieuwenhuis' boeken ${ }^{\mathrm{I}}$ ) een duidelijk beeld.

In 1892 begon de Leidsche hoogleeraar Dr. K. Martin zijn reis naar de Molukken in opdracht van het „Koninklijk Instituut voor Taal-, Land- en Volkenkunde van Nederlandsch-Indië", een voornamelijk geologische onderzoekingstocht ${ }^{2}$ ), later gevolgd door meer algemeen Indische studiereizen van denzelfden hoogleeraar; voorts vertoefde Prof. E. Selenka in 1890 op de Groote Soenda-eilanden voor het verzamelen van embryologisch materiaal; Dr. A. Strubell bracht een verzameling bijeen van land- en zoetwatermollusken op Java en de Molukken; Prof. Richard Semon deed op de terugreis van zijn Australische onderzoekingstocht ook Java en de Molukken aan, waarvan in

i) G. A. F. Molengraaff, I900. Dorneo expeditie. Geologische verkenningstochten in Centraal-Borneo. (Leiden en Amsterdam, 1900).

A. W. NiecWenhuis, 1900. In Centraal-Borneo. (Leiden, 1900) en r904-1906, Quer durch Borneo (Leiden, 1904-1906).

2) K. Martin, iS94. Reisen in den Molukken, in Ambon, den Uliassern, Seran und Buru. (Reisverhaal. Leiden, i894). K. Martin, 1903. Idem. Geologischer Teil. (Leiden, 1903). 
een groot standaardwerk ${ }^{2}$ ) de resultaten bewerkt zijn en waarover hij zijn mooie "Im Australischen Busch" ") schreef. Verder zijn te vermelden de tochten van Whitehead ${ }^{3}$ ) door Borneo en de reizen van Bedot en Pictet door den ganschen Archipel met een belangrijk zoölogisch werk ${ }^{4}$ ) als resultaat.

Van groot belang om de uit de resultaten getrokken conclusies waren de reizen der neven P. en F. SARAsin, die vooral Celebes als onderzoekingsveld kozen en daar van 1893 tot 1896 , later nog van 1902 tot 1903 vertoefden. Hun standaardwerk is: „Materialiën zur Naturgeschichte der Insel Celebes" 5), in vijf deelen, terwijl ook een mooi reisverhaal van hun hand verscheen ${ }^{6}$ ). De Duitsche hoogleeraar W. Küкenthal bereisde, gesteund door de Senckenbergische Naturforschende Gesellschaft in 1893 en 1894 voornamelijk de Noord-Molukken en bracht hier een groote hoeveelheid wetenschappelijk materiaal bijeen. beschreven in verschillende deelen Abhandlungen van het genoemde genootschap ${ }^{7}$ ), terwijl een meer populair boek: „Forschungsreisen in den Molukken und in Borneo" zijn reisverhaal bevat. Alfred Madss, de later zoo bekende Sumatra-reiziger

1) R. Semon, r894-r9o3. Zoölogische Forschungen in Australiën und dem Malaiïschen Archipel. 5 Bde. (Jena, 1894-1903).

2) R. Semon, 1896. Im Australischen Busch und an den Küsten des Korallenmeeres. Reiseerlebnisse und Beobachtungen eines Naturforschers in Australien, Neu-Guinea und den Molukken. (Leipzig, 1896).

3) J. Whitehead, 1893. Exploration of Mount Kina Balu, North Borneo. (London, 1893).

4) C. Pictet et M. Bedot, I893. Compte rendu d'un voyage scientifique dans l'archipel malais. (Genève, 1893).

5) P. und F. Sarasin, I898-1905. Materialiën zur Naturgeschichte der Insel Celebes. 5 Bde. (Wiesbaden, 1898-1905).

$\left.{ }^{6}\right)$ P. und F. S.Arasin, 1905. Reisen in Celebes ausgeführt in den jahren 1893-1896 und 1902-1903. 2 Bde. (Wiesbaden, 1905).

7) W. KÜKENTHAL, IS96-1903. Ergebnisse einer zoologischen Forschungsreise in den Molukken und in Borneo. (Abhandl. Senckenberg. naturf. Gesellsch. Bd. XXII, (reisverhaal) en XXIII-XXV, 1896-1903). 
ALGEMEENE NATUURIVTENSCHAP NA I 850.

deed zijn eerste tocht naar de Mentawei-eilanden in het voorjaar van $\left.1897^{\prime}\right)$, vooral uit ethnographisch oogpunt van belang; op een van zijn latere Sumatra-reizen ${ }^{2}$ ), werd hij (1908) vergezeld door Dr. P. J. Klemweg DE ZivaAn, die mooi materiaal voor zoölogische onderzoekingen bijeenbracht, dat in Amsterdam bewerkt werd. Verder moeten in de laatste jaren der negentiende eeuw nog vermeld worden de reizen op Sumatra van Dr. Walther Volz, een Zwitser, wiens dierkundige collecties in de "Zoölogische Jahrbücher" bewerkt zijn, en een kort bezoek van de Duitsche Valdivia-expeditie ${ }^{3}$ ) onder leiding van CARL CHUN aan Sumatra's Westkust.

Deze laatste jaren der negentiende eeuw zouden bestemd zijn in Nederland en in Indië groote dingen te zien gebeuren. Er was reeds lang, in de eerste plaats door Prof. Hubrecht, in de bijeenkomsten van de Treub-Maatschappij gesproken over de wenschelijkheid van systematisch zeeonderzoek van den ganschen Archipel, waar de zee een tweemaal zoo groot oppervlak beslaat als het land, en waar door het groote aantal eilanden en eilandjes met grillig gevormde kustlijnen een ontzaglijke strandlengte gevonden wordt. Plannen werden gemaakt, en in 1897 werd besloten tot het ondernemen van een exploratietocht vooral door Indië's Oosthoek onder leiding van Prof. Max Weber. Maatschappij, Regeering en particulieren werkten samen, zoodat H. M. Siboga, een tweeschroefskanonneerboot voor den Indischen dienst, met volle natuur-

I) A. MaAsS, 1902. Bei liebenswürdigen Wilden. (Berlin, 1902).

2) A. MaAss, 1904. Quer durch Sumatra. (Berlin, 1904).

A. MaAss, 1910-1912. Durch Zentral Sumatra. 2 Bde. (Berlin, r9ro-r9r2). De zoölogische publicaties der specialisten-medewerkers in deel III).

3) Wissenschaftliche Ergebnisse der Deutschen Tiefsee-Expedition auf dem Dampfer Valdivia, 1898-1899. Herausgegeben von CarL Chun. 20 Bde nog niet voltooid. (Jena, 1902-19..).

C. Chun, 1902. Aus den Tiefen des Weltmeeres. (Jena, 1902). 
wetenschappelijke uitrusting den I 6den December I 898 Amsterdam en 7 Maart 1899 Soerabaja verlaten kon onder commando van den toenmaligen Luitenant t. Zee re klasse, thans Vice-Admiraal G. I. Trdeman. De wetenschappelijke staf bestond uit: Prof. Max Weber als leider, Mevr. Dr. A. Weber-van Bosse, aan wie belangrijke algenstudies over onzen Archipel te danken zijn, Dr. J. Verslurs, thans hoogleeraar te Giessen en docts. H. F. Nierstrasz, tegenwoordig hoogleeraar te Utrecht als zoölogen en Dr. A. H. Schnidt als medicus met uitstekende zoölogische bekwaamheden. Het fotografeerwerk werd door den Heer Nierstkasz, het teekenwerk door den Heer J. W. Huvsmans, teekenaar van 's Lands Plantentuin, verricht. De tocht ging van Soerabaja uit langs Bali, Lombok, Soembawa, Soemba door de Flores-straat naar Saleyer, door de straat van Makassar, Celebes-Zee, langs Halmaheira, Batjan, Obi, Waigeoe naar Nieuw-Guinea, vandaar naar Ceram, Misool en Ambon, Aroe, dan naar Boeroe en door de straat van Boeton naar Saleyer, weer naar Ambon, en langs Timor, Flores, Soembawa, Kangean en Bawean terug naar Soerabaja, waar de Siboga 26 Februari 1900 aankwam. De resultaten dezer expeditie zijn schitterend; een reeks monografiën ${ }^{\mathrm{I}}$ ) over de oceanografische waarnemingen, de fauna en flora van stranden, riffen, plankton en diepzee, bewerkt door een lange rij van specialisten-onderzoekers, ieder zijn bijdrage gevend over zijn arbeidsveld, toont ons hoe uitnemend zoowel expeditie als uitwerking van materiaal verzorgd waren. De wensch van Prof. Weber, waarmee hij de eerste dier reeks monografiën besluit: „Puisse l'oeuvre du Siboga, dont le présent article constitue l'introduction, contribuer à augmenter nos connaissances sur cette ensoleillée partie du globe, qui

r) Siboga-Expeditie. Uitkomsten op zoülogisch, botanisch, oceanographisch en geologisch gebied, uitgegeren door MAX WEBER. Tot nu toe verschenen att. I-73. (Leiden, 1902-1914). 
nous offre tant de questions du plus haut intérêt" " $)$, is, dank zij Prof. Weber's werkkracht en organisatie, op de meest schitterende wijze in vervulling gegaan. En mevrouw WeBERVAN Bosse heeft den gewonen lezer een grooten dienst bewezen door haar : „Een jaar aan boord H. M. Siboga”, een aantrekkelijke reisbeschrijving ${ }^{2}$ ).

De nieuwe eeuw opent de reeks Nieuw-Guinea expedities, tochten naar het groote eiland, dat, eigendom van drie koloniseerende mogendheden en nog zoo weinig bekend, een aantrekkingskracht uitoefent op den ontwaakten ondernemingsgeest der Hollanders. Van oudsher had de mystiek van een sneeuwgebergte in de tropen zijn bekoring op onderzoekingsreizigers uitgeoefend; een prachtig-gedokumenteerde arbeid van Wichmann ${ }^{3}$ ) geeft hiervan een uitnemend overzicht. Weer is het de Treub-Maatschappij, die deze taak op zich neemt; regeeringssubsidie en hulp van particulieren brengen weer steun en in 1903 vertrekt de Noord-Nieuw-Guinea-Expeditie ${ }^{4}$ ) onder leiding van den Utrechtschen hoogleeraar Wichuann, bijgestaan door Dr. L. F. DE Beaufort en Mr. H. A. Lorentz als zoölogen, den off. v. gezondheid G. A. J. v. D. SANDE als ethnograaf, terwijl een mantri van den plantentuin voor botanische verzamelingen zorgt, een succesvolle onderzoekingstocht van een half jaar, waarvan wij het reisverhaal ${ }^{5}$ ) aan Mr. LoRENTZ danken.

1) MAX WEBer, 1902. Introduction et description de l'Expédition. (Uitk. en onderz. der Siboga-expeditie. Monographie I, I59 pp.). p. I52.

2) A. Weber-VAN Bosse, 1904. Een jaar aan boord H. M. Siboga. (Leiden. 1904).

3) A. Wichmanv, 1909-1912. Entdeckungsgeschichte von Neu-Guinea. (Nova Guinea I-II. vol. I. bis 1828 ; vol. II. I $^{\text {re }}$ partie, I828-1885; vol. II. $2^{\text {me }}$ partie, 1885-1902. Leiden, 1909-1912).

Zie ook A. Wichmans, 1905. Het onderzoek van Nieuw-Guinea in vroegere eeuwen. (Bull. Treub-Maatschappij. N ${ }^{\circ}$. 49. 1905 . I2 pp.).

4) Zie Bulletin v. d. Treub Maatschappij. $\mathrm{N}^{\circ}$. $4 \mathrm{I}-47$.

9) H. A. Lorentz, 1905. Eenige maanden onder de Papoea's. (Leiden, igu5). 
Dan volgt de "Zuidwest-Nieuw-Guinea-Expeditie" ") van het Kon. Ned. Aardr. Genootschap, daartoe door het in I902 bijeengebrachte VETH-fonds in staat gesteld (I904-I905), waaraan deelgenomen werd door M. Posthumes Merjes, E. J. DE Rochemont en J.W. R. Kocir, en gedurende welke wel faunistisch verzameld werd, al bleef het eigenlijke doel der expeditie, in het Sneeuwgebergte door te dringen, onbereikt. Gunstiger resultaat had weer de ,Maatschappij”, die in 1907 de ,Zuid-Nieuw-GuineaExpeditie" ${ }^{2}$ ) organiseerde onder leiding van Mr. H. A. Lorextz, met J. W. vax Nochurs en G. M. Versteeg als tochtgenooten, van wie Lorextz zoölogische en Versteeg plantenverzamelingen bijeenbracht. Sedert hebben weer twee Nederlandsche NieuwGuinea-Expedities plaats gehad, waarvan de eerste ${ }^{3}$ ), onder leiding van Lorextz, en met Vax Nounuys, Dr. L. S. A. M. vox Röser en luit. D. Habbema als deelnemers den Ssten Nov. I 909 op een hoogte van 446 I M. de eeuwige sneeuw op den Wilhelminatop bereikte, en de tweede (kapitein A. Franssex Herderschee leider; G. M. Versteeg, Dr. A. A. Pulle, Dr. P. F. Hibrecirt en luit. L. A. SNell deelnemers; I9I2-I9I ${ }^{4}$ )) eerst kort geleden teruggekeerd is. De bewerking van al het op deze reizen bijeengebrachte materiaal, zoölogisch, botanisch, geologisch, ethnografisch, geschiedt door een aantal Europeesche onderzoekers, die allen hun arbeid publiceeren in een groot standaardwerk: „Nova Guinea” s).

r) De Zuidwest-Nieuw-Guinea-Expeditie 1904-1905 van het Kon Ned. Aardr. Genootschap. (Leiden, I908).

2) Zie Bulletin van de Treub-Maatschappij. $\mathrm{N}^{\circ} \cdot 50,52-5 \mathrm{~S}$.

3) Zie Bulletin van de Treub-Maatschappij. No.59-64 en H. A. Lorextz. I913. Zwarte menschen-Witte bergen. (Leiden, I9I3).

4) Zie Bulletin van de Treub-Maatschappij. No. 65-68.

5) Nova Guinea. 1903. Uitkomsten der Ned. Nieuw-Guinea Expeditie in 190,3 onder leiding van Dr. A. Wichuavs. (Leiden, r9o5-heden).

Idem. I907 en rgog. Uitkomsten der Ned Nieuw-Guinea Expeditie in 1907 (1909) onder leiding van Mr. H. A. Lorentz. (Leiden, rgoS-heden).

Idem, 1913. Uitkomsten der Ned. Nieuw-Guinea Expeditie in 1912-1913 onder leiding van A. Franssex Herderschee. (Leiden, 1913-heden). 
ALGEMEENE NATUURWETENSCHAP NA I 850 .

Naast deze min of meer ,particuliere" expedities werd het onderzoek van Nieuw-Guinea vanaf 9 Juni 1907 ook van Regeeringswege ter hand genomen ${ }^{x}$ ): met een juiste carteering van Zuid-Nieuw-Guinea als voornaamste doel werd een exploratiedetachement uitgerust, dat, in den eersten tijd geleid door de kapiteins A. J. Gooszen, Weber en A. B. IV. Schineffer, naar de aanwijzingen werkte van den zelfstandigen assistent-resident. Vanuit Merauke maakte dit detachement tochten, waarbij de Julianatop werd ontdekt. Daarna besloot het Gouvernement in I 909 tot uitrusting van drie nieuwe exploratie-detachementen: een onder kapt. F. J. P. SACHSE (Humboldt-baai), een onder kapt. A. Franssen Herderschee (Mamberamo) en een onder leiding van F. H. Dumas en kapt. K. F. Kосн (vanuit Fak-Fak). Zuiver natuurwetenschappelijk werk was bij deze exploratiedetachementen uit den aard der zaak bijzaak; deskundigen gingen in den regel niet mede, behalve mijningenieurs voor geologisch onderzoek: Dr. J. K. van Gelder, O. G. Heldring en Dr.P.F. Hubrecht. De belangrijkste botanische verzamelingen. werden op deze tochten bijeengebracht in de buurt van Merauke (I907-igo8) door den off. v. gez. B. Branderhorst en door den off. v. gez. der Humboldtbaai-expeditie (I9IO) K. GjelleruP.

Meer gegevens op zoölogisch en geologisch gebied werden bereikt door expedities van deels andere, deels gemengde nationaliteit: de Nederlandsch-Duitsche Grensregelings-Commissie en een tweetal Engelsche Expedities in Nederlandsch-Nieuw-Guinea.

De gemengde Nederlandsch-Duitsche Grensregelings-Commissie (Juni-November 1910$)^{2}$ ), waarin opgenomen was het

1) Zie A. J. Gooszen, 1913. Hoe Nederlandsch-Nieuw-Guinea geëxploreerd. werd en wordt. (Tijdschr. Kon. Ned. Aardr. Gen. $2^{\text {e }}$ serie, XXX. 1913. p. 638-651).

2) Uittreksel uit het verslag der Commissie ter voorbereiding van de aanwijzing eener natuurlijke grens tusschen het Nederlandsche en het Duitsche Gebied op Nieuw-Guinea. (Den Haag, I9ı. Met foto's en 4 kaarten). 
exploratiedetachement onder leiding van kapitein F. J. P. SACHsE, bestond, wat het Nederlandsche gedeelte betreft, uit den luit. t. zee y e klasse J. L. H. Luymes, den genoemden kapitein Sachse, den off. v. gezondheid K. Gjellerup, den geoloog Dr. P. F. Hubrecut en den zoöloog Dr. P. N. van Kanpen, terwijl de Duitsche afdeeling gevormd werd door Prof. Dr. L. Scirultze als leider, aan wien toegevoegd was de luit. t. zee 2 e kl. A. F. H. Dalhuisen, voorts bergassessor Stollé en Dr. Kopp als geneesheer. Het geologische werk op deze expeditie werd verricht door Dr. Hubrecrit, het zoölogisch werk door Dr. van Kampen, terwijl de off. v. gez. GJeLlerup voor het verzamelen van planten zorgde. Het faunistisch en floristisch materiaal is of wordt nog bewerkt; het is eigendom van het Departement van Landbouw te Buitenzorg.

Eind 1908 of begin 1909 deed de British Ornithologists Union een verzoek aan onze Regeering, om vanuit de Otakwa een expeditie naar het Carstensz-gebergte te mogen ondernemen, welk verzoek werd toegestaan, mits de expeditie plaats vond na I Januari I9IO. De eerste georganiseerde tocht (Jan. 1910-April 1911) ${ }^{\mathrm{I}}$ ) onder leiding van W. Goodfellow, met als deelnemers A. F. R. Wollaston, C. G. Rawling en Dr. Eric Marsiall, aan wie een Nederlandsch dekkingsdetachement was toegevoegd, had niet het verwachte resultaat; de groote moeilijkheden ondervonden in de moerassige streken langs de Mimika-rivier, die men moest doortrekken, alvorens den voet van den Carstensz-top te bereiken, waren oorzaak, dat van een beklimming moest afgezien worden en de tocht afgebroken werd.

1) C. G. Rawling 19r3. The land of the New Guinea Pygmies. An account of the story of a pioneer journey of exploration into the hearts of New Guinea. (London, I913). en:

A. F. R. Wollaston, r912. Pygmies and Papuans, the Stone-Age to-day in Dutch New Guinea. (London, I912). In het appendix een voorloopige behandeling der vogels door OGILvie-Grant. Zoölogische resultaten zijn verder gepubliceerd in Transact. Zoolog. Soc. of London XX, r9r 4. 
ALGEMEENE NATUURIETENSCHAP NA I 850.

Maar de tweede expeditie (Sept. 1912-Maart I9I3) had gunstiger resultaat, daar ze op 30 Januari $19{ }_{1} 3$ de sneeuwgrens tusschen de beide Carstensz-toppen bereikte. Deze expeditie bestond uit Dr. Wollaston en C. Boden Kloss, terwijl het welslagen van dezen onderzoekingstocht grootendeels te danken is aan den leider van het dekkingsdetachement, Ie luitenant der infanterie A. VAN DE WATER. De verzamelingen dezer expedities, die zich in het British Museum bevinden, worden daar bewerkt.

Dat ook in het begin van de twintigste eeuw tal van particuliere onderzoekers reizen naar onzen rijken Archipel ondernamen, ligt voor de hand; het voetspoor der voorgangers wijst hun den weg; belangrijke vondsten van vroegere reizigers zijn hun een prikkel, om bijzondere deelen van den Archipel te gaan bewerken. Al deze personen en expedities op te sommen, zou in dit bestek ondoenlijk zijn; uit de groote massa de voornaamste kiezende, noemen wij achtereenvolgens de tochten omstreeks 1900 van den Duitschen geoloog Dr. G. Boенм ${ }^{x}$ ), die vooral de Molukken tot onderzoekingsveld koos en naar aanleiding van door de Siboga op Misool gevonden fossielen, o.a. dit eiland bezocht; het exploratiewerk van de beide Freiburger Molukken-expedities (1906-1907 en I9IO-I9II) ), onder leiding van Dr. K. Deninger, die op de tweede expeditie vergezeld werd door den zoöloog Dr. E. Stresemann en den physicus Dr. O. D. Tauers; de reis van den geoloog Dr. J. IVanner $^{3}$ ) naar de Molukken en Timor (1907); de Sundaexpeditie uitgerust door de „Frankfurter Verein für Geographie

I) Zie de titels van zijn publicaties bij VERBEEK, I9I 2. p. IS6-IS7. ( $N^{\circ}$. 2 I I I - 2 I 22).

$\Rightarrow$ Hierover is nog geen algemeen werk verschenen, wel publicaties bijv. van Stresemand. (Journ. f. Ornith. I9I3. p. 597 el Novitates Zoölogicae XXI, I9I4. p. 25).

3) Zie de titels van zijn publicaties bij VerbeEk, I9r2. p. 207. (N०.2376-2383). 
und Statistik" onder leiding van Dr. J. Elizert $\left(1907^{-1}\right)$; de zeer belangrijke tocht van Dr. H. Mertox en Dr. J. Rotx naar de Aroe- en Kei-eilanden (Oct. 1907-Aug. 1908 ²)), gesteund door de Senckenbergische naturforschende Gesellschaft, die ook twee deelen harer "Abhandlungen" ter beschikking gesteld heeft voor de mededeeling der resultaten, die vooral op zoögeographisch gebied van groote beteekenis zijn; het werk van den geoloog A. Torler ${ }^{3}$ ) in Djambi (Sumatra); de geologische reis van Prof. Dr. K. Martin en Mevr. H. Martin-Icken (I9IO ${ }^{4}$ )): de tocht van den mijningenieur E. C. Abendanon naar Celebes $\left(1909-1910^{5}\right)$ ), die ook belangrijke zoölogische verzamelingen bijeenbracht, welke in Amsterdam bewerkt zijn ${ }^{\circ}$ ); het bezoek van Dr. en Mevrouw L. F. DE Bealfort aan het zoo belangwekkende en weinig bekende eiland Waigeoe en aan Ceram (I 909I9IO), welks resultaten voor de zoögeographie belangrijk zijn geweest ${ }^{7}$ ); het onderzoek van Dr. J. P. KreIwEG DE ZwAAx op

3) J. Elbert, 19ir-1912. Die Sunda-Expedition des Vereins für Geographie und Statistik zu Frankfurt a. Main. Festschrift zur Feier des 75-jährigen Bestehens des Vereins. 2 Bde. (Frankfurt a. MI. 19I I-1912). Aan de tweede band werd o. a. meegewerkt door onze langenooten Dr. W. van Bemaei.en, Dr. H. Halimer en Mej. Dr. C. Popta.

$\Rightarrow$ H. Merton, I9II-rgr3. Ergebnisse einer zoölogischen Forschungsreise in den südöstlichen Mlolukken. (Aru- und Kei-Inseln). (Abh. Senckenb. naturf. Gesellsch. XXXIII u. XXXIV, ı9ı-r913. Hierin Reisebericht XXXIII. p. $\mathrm{x}-208$ ).

3) Zie de titels van zijn publicaties bij Vereeek, I9I2. p I35. ( $N^{\circ}$. I 402-1408).

4) K. Martin, igi . Vorläufiger Bericht über geologische Forschungen auf Java I. (Sammlungen geol. Reichsmuseums. Leiden, IX. p. I- 76 ).

5) Zie de titels van zijn publicaties bij VFRBEEK, I912. p. 172. (No. 1922-1924).

6) Door Prof. Dr. Max IVerer. (Zoetwatervisschen. Bijdragen tot de Dierkunde, uitg. door Artis XIX, 1913. p. 197-213) en J. H. KRLine. Zoetwatermollusken. (Ibidem. XIX. p. 217-236).

7) L. F. DE BEAUfort, I9r3. Short narrative of the voyage. (Bijdragen tot de Dierkunde XIX. p. 3-5). De bewerking der resultaten werd door verschillende medewerkers gepubliceerd. (Ibidem. XIX. p. 9-164). 
ALGEMEENE NATUURIVETENSCHAP NA 1850.

Nias $^{x}$ ) (1910), waarvan het zoölogisch materiaal eveneens in Amsterdam bewerkt is ${ }^{2}$ ), en de tocht van Prof. Dr. G. A. F. Molengraaff met den mijningenieur F. A. H. Weckherlin de Marez Oyens en den door de Regeering toegevoegden mijningenieur Dr. H. A. Brouwer $\left(191 \mathrm{I}^{3}\right)$ ), gedeeltelijk een uitvloeisel van Wanners reis, en waarop door De Marez Ovens een mooie verzameling van zoetwatervisschen is bijeengebracht, bewerkt door Prof. Dr. Max Weber en Dr. L. F. de Beaufort ${ }^{4}$ ).

Het voornaamste doel, dat al deze reizigers en expedities beoogden, was na de bestudeering van flora en fauna, zoowel recent als historisch, niet alleen de bekendheid met Indië's plantengroei en dierenwereld, maar vooral het verwerken van de langs dezen weg verkregen resultaten voor de oplossing van grootsche problemen: het ontstaan en de ontwikkeling van onzen Archipel door de eeuwen heen tot zijn tegenwoordigen toestand, problemen in de eerste plaats van zoögeographische en geologische natuur, die dank zij den ingespannen arbeid van velen ons thans veel helderder voor oogen staan en veel meer een goed einde beloven, dan voor een twintigtal jaren.

En indien over eenigen tijd deze vraagstukken hun beantwoording hebben gevonden, dan zal Nederland met trots mogen wijzen op den door Nederlanders verrichten arbeid.

x) J. P. Klemweg de Zivaan, r913-rgr4. Die Insel Nias bei Sumatra. I. Die Heilkunde der Niasser. (Den Haag, 1913). II. Anthropologische Untersuchungen iber die Niasser. (Den Haag, 1914).

2) De bewerking hiervan door een aantal specialisten zal gepubliceerd worden in het derde deel van J. P. KLEIWEG DE ZWAaN. t. a. p.

3) G. A. F. Molengraaff, igr I. Mededeelingen omtrent de Timor-expeditie (Tijdschr. Kon. Ned. Aardr. Gen. $2^{\text {e }}$ serie, XXVIII, i9ı I. p. $470-475$ en $839-840$ ).

4) Max Weber en L. F. DE Beaufort, 1912. On the freshwater fishes of Timor and Babber. (Versl. K. A. W. Amsterdam 29 Juni 1912. p. 235-240). 


\section{HOOFDSTUK VII.}

\section{De verdere ontwikkeling van 's Lands Plantentuin en het plantkundig onderzoek na $\mathbf{1 8 5 0}$.}

's Lands Plantontuin was behouden gebleven. De vijanden van Buitenzorg's instelling hadden in Teysmaxi een verdediger ontmoet, die, aanzien noch rang ontziende, iederen aanvaller wist te ontwapenen door zijn karaktervastheid en zijn buitengewone openhartigheid. Als nog in 1856 de groote Utrechtsche scheikundige G. J. Mulder in een geheim schrijven aan den Minister van Koloniën de meening verkondigt, dat men z. i. zich in Java's Plantentuin te weinig toelegde op den invoer van nuttige gewassen, en veel te veel belang hechtte aan het kweeken van sierplanten, dan antwoordt Tersians, onder overlegging van een lijst van 50 planten, ,die hun verspreiding of in kultuur brengen op Java aan den Plantentuin te danken hebben”, eenvoudig dit: „De door den hoogleeraar gegeven wenk: er behoort alzoo naar mijne meening steeds op uitgezien te worden, wat er van andere gewesten naar Java kan worden overgebracht, om daar gekweekt te worden, en na in een kweektuin aldaar beproefd te zijn, overgebracht te worden op die gronden en in die streken, welke tot het in het groot 
kultiveeren de beste zijn, komt dus wat laat, wijl dezelve reeds sedert 40 jaren is in practijk gebracht". En in die lijst treffen wij aan: twee kaneelsoorten, notenmuscaat, kruidnagelen, suikerriet, kina, kamfer, katoen, enz.

Maar daartegenover is Teysmann's houding jegens den jongen Binnexdijk, die hem eigenlijk eenigszins opgedrongen is, volkomen welwillend, vooral nadat hij BiNNENDIJK heeft leeren kennen en waardeeren. Want de nieuwe assistent-hortulanus was een jonge man van groote bekwaamheid; vooral in het vervaardigen van plantbeschrijvingen toonde hij zich spoedig de gelijke van zijn chef; samen stelden zij reeds in 1852 een nieuwen, nooit verschenen, catalogus samen, een taak, die de krachten van den pas aangekomen Birnevdijk wel wat te boven ging. Samen publiceerden zij ook in verschillende jaargangen van het Natuurkundig Tijdschrift van Ned.-Indië, een 270 -tal plantenbeschrijvingen ${ }^{x}$ ) voor een deel voorloopers van den in I 866 uitgegeven derden catalogus.

Wetenschappelijke botanische hulp kreeg Teysmann in deze periode allereerst weer van HASSKARL, die, teruggekeerd van zijn tweejarige reis naar Zuid-Amerika ${ }^{2}$ ) en benoemd tot „Directeur van de Kina-plantsoenen", zooveel deze werkkring hem toeliet Teysunn, met wien de oude vriendschapsband hernieuwd was, steun verleende bij het bewerken en beschrijven van Buitenzorg's plantenschat. Hoewel ook deze, Hassiarl's derde Indische periode slechts anderhalf jaar duurde, vond hij toch nog gelegen-

1) Zie J. M. JANSE, r892. Wetenschappelijke onderzoekingen verricht aan of met behulp van 's Lands Plantentuin. (In: „'s Lands Plantentuin". 18 Mei 181718 Mei 1892. p. 235-378). p. 248.

2) Zie W. H. DE VRIESE. De Kina-boom uit Zuid-Amerika overgebragt naar Java onder de regeering van Koning Willem III. 's Gravenhage, I855 en KARL Müller, 1873. Die Verpflanzung des Chinabaumes und seine Kultur. (Unsere Zeit, 1873. p. $62-74,186-215,258-274$ ). 
heid een boekje te publiceeren: „Retzia, sive observationes botanicae", waarvan hij na zijn terugkomst in Europa een tweeden druk bezorgde. Want Hasskaki's gezondheid had door de inspannende vermoeienissen in het Andes-gebergte en door droevige huiselijke omstandigheden zeer geleden en naar het schijnt is ook Iuxghuns's kritiek op de organisatie der kinacultuur op Java mede een oorzaak geweest, dat de eigenlijke stichter dier cultuur in het midden van 1856 met verlof naar Europa vertrok, welk verlof nooit zou eindigen. Immers, nadat door de zeereis zijn gezondheidstoestand aanmerkelijk verbeterd was, vestigde hij zich te Kleef en wijdde hij zijn verdere leven aan de wetenschap. Hier bewerkte hij (I S6I en I 866) de sleutels op de beide Indische Klassieken: Van ReEde's Hortus Malabaricus ') en Rumpints' Herbarium Amboinense ${ }^{2}$ ); hier verschenen nog een aantal andere studies van zijn hand, meest floristische, over tropische plantenfamilies. Bijna 40 jaar lang zou Hasskarl, door de Nederlandsche Regeering met een pensioen van $f 1000$ beloond, zich nog met zijn lievelingsstudiën kunnen bezighouden; op 82-jarigen leeftijd (5 Januari I 994 ) ging de nooit rustende man de eeuwige rust in.

Terwijl Junghum hem in 1856 opvolgt als inspecteur der kina-cultures, maar zich door zijn reizen niet veel met 's Lands Plantentuin kan inlaten, krijgt Tersuans in 1859 opnieuw botanische hulp van S. KLKz, die onder den naam van J. Aminv als soldaat bij het Indische leger in dienst grekomen, op zijn verzoek bij 's Lands Plantentuin geplaatst wordt, daar gedurende zijn geheelen militairen diensttijd (tot I864) uitstekend behulpzaam is in het determineeren van toegezonden planten, en dan ook in IS64 een

ז) Zie p. 23, noot 2,3 en 4 .

2) Zie p. 46 , noot 2 . 
'S LANDS PLANTENTUIN NA I850.

paar verhandelingen ${ }^{5}$ ) publiceert. In dat jaar vertrekt KuRz naar Engelsch-Indië, waar hij ook nog botanisch werkzaam is geweest.

Teysmann zelf doet in dezen tijd reizen door den geheelen Archipel: in 1855 bezoekt hij Bantam, Preanger, Banjoemas en Krawang; in 1857 Palembang en de Lampongsche districten, iis 1859 geheel Java, Madoera en Bawean, en in gezelschap van Prof. De VRiese, wiens meening omtrent Teysmann geheel veranderd is, de Molukken, in I86I gaat hij naar Bagelen en in I $\$ 6_{3}$ naar Siam. Dan schijnt er een tijdje stilstand geweest te zijn, waarna wij in 1869 weer aanteekeningen vinden over een reis naar Bangka, in 1874 naar Bangka, Riouw, Liengga en Timor; het volgende jaar naar Borneo's westkust, dan naar Billiton, Molukken, Celebes (1877).

Terwijl Hasskari, Teysmann, Binnendij en Kurz in Indië zelf aan de bestudeering der tropische flora werken, vinden wij in Europa een tweetal geleerden, die van materiaal, hun uit Buitenzorgs tuin toegezonden, een dankbaar gebruik maken voor hun geschriften: ten eerste ZoLLINGER, de Zwitser, dien wij reeds in het jaar 1844 aan den Plantentuin aantroffen en die ook nog van I854 tot I8,59 Oost-Java bereisde, maar toen door herhaalde ongesteldheden veel minder werkkrachtig was, dan in zijn eerste periode. Teruggekeerd in zijn vaderland, kon ZoLlisger de bekoring van dien steeds weer boeienden plantengroei niet vergeten; hij blijft arbeiden en geeft o.a. een werkje: "Gedachten over Plantenphysiognomie in het algemeen en over die der vegetatie van

I) S. Kurz, I864. Korte schets der vegetatie van het eiland Bangka. (Nat. Tijdschr. v. N.-I., XXVII. p. 142-235).

S. KuRz, I865. Eenige kruidkundige mededeelingen. (Nat. Tijdschr. v. N.-I., XXVIII. p. 164-I68). 



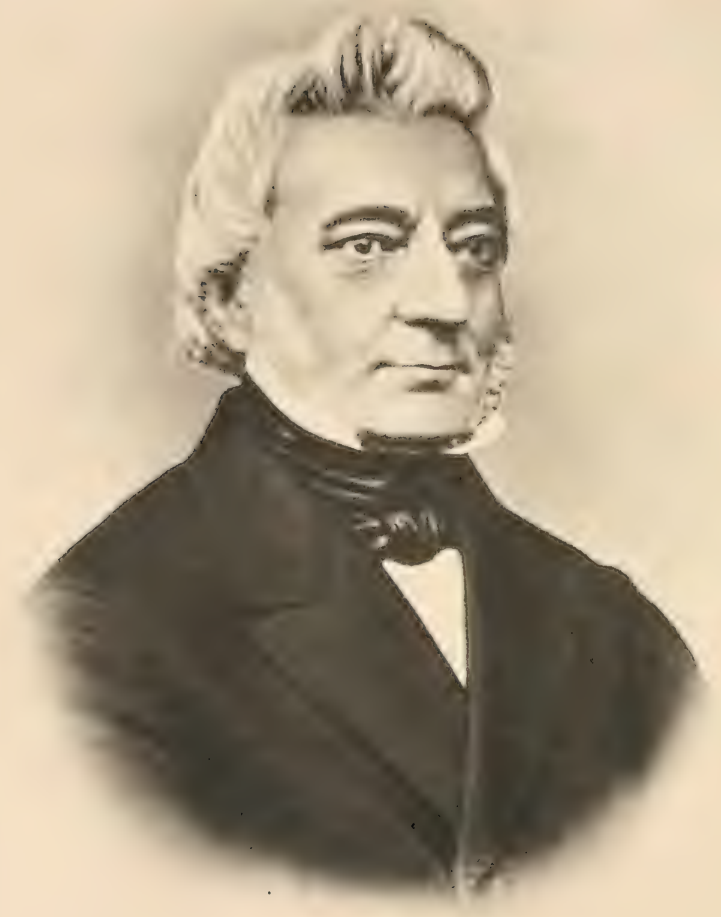

F. A. W. MIQUEL. 
'S LANDS PLANTENTUIN NA 1850.

Java in het bijzonder" uit, voorts artikelen in het Nat. Tijdschr. ${ }^{\mathrm{I}}$ ).

En naast ZolLINGer valt hier een man te vermelden, die nooit den bodem onzer Indische koloniën betreden heeft en wien wij toch zeer belangrijke bijdragen tot de kennis van Indië's plantengroei danken: F. A. W. Miquel, geb. 24 October I 8 I I, hoogleeraar te Utrecht, later tevens directeur van 's Rijks Herbarium te Leiden ${ }^{2}$ ). Miquel was een zoon van den burgemeester van Bentheim, werd door zijn vader voor de universiteit klaargemaakt en ging in $1 \$ 29$ naar Groningen om daar in de letteren te studeeren. Maar al spoedig verwisselde hij deze studie met die der medicijnen en der natuurwetenschappen, beantwoordde twee botanische prijsvragen en vestigde daardoor de aandacht der geleerden op zich. Tot doctor medecinae gepromoveerd, werd hij werkzaam aan het Binnengasthuis te Amsterdam, daarna lector aan de Clinische School te Rotterdam, bedankte voor een beroep als hoogleeraar aan Deventers Athenaeum, omdat daar een hortus ontbrak. Totdat hij den 2 den Maart 1846 het professoraat aan het Athenaeum te Amsterdam aanvaardde; dertien jaar later deze inrichting met de Utrechtsche Universiteit verwisselde, om in I 862, na BLuME's dood, tevens met het directeurschap van 's Rijks Herbarium belast te worden. Negen jaar bleef MrQuel deze ambten waarnemen tot hij 23 Januari I87 I aan de wetenschap ontviel, gesloopt door een ongeneeslijke kwaal, die hem reeds bij herhaling het arbeiden zoo moeielijk gemaakt had.

I) H. Zortrager, IS57. Observationes botanicae novae. (Nat. Tijdschr. v. N.I., XIV. p. $145-176)$.

H. Zoldiniter, 1859. Iets over de natuurlijke geschiedenis van Madoera. (Nat. Tijdschr. v. N.-I., XVII. p. $243-248$ ).

$\Rightarrow$ Zie C. J. Matthfs, rS72. Levensberigt van F. A. W. Mrgcei.. (Jaarb. Kon. Ak. Wet., I872. p. 29-49, met bibliographie). 
'S LANDS PLANTENTUIN NA I 850.

Mincel was een man, die zijn eigen leven gemaakt heeft tot wat het geworden is; met systematische onderzoekingen begon hij en zijn gansche leven heeft hij in die richting gewerkt, zich gegeven eerst aan de flora van zijn nieuwe vaderland, getuige zijn medewerking aan VAN HALL's ,Flora Belgii Septentrionalis" van I832 en zijn ,Disquisitio geogr.botanica de plantarum Regni Batavi distributione" van i 837 , om dan langzamerhand naar de studie der tropischegewassen over te hellen, gevoelend hun groote aantrekkelijkheid, al kent hij alleen kasplanten en zoo vaak geminachte herbarium-exemplaren. Vooral de Cycadeeën zijn het, die zijn aandacht trekken, daarnaast de Suriname-collecties van H. C. Focke en de plantenpalaeontologie: zoowel Limburgsche krijtflora, als fossiele Cycadeeën. Als standaardwerken zijn daarna van zijn hand verschenen "Flora van Nederlandsch-Indië" (1 855 ) en de „Annales Musei Botanici Lugduno-Batavi" (I863-i869). Een veelzijdig systematicus was Miquel, een bescheiden man, als plantenkenner en plantenbeschrijver ook in het buitenland gewaardeerd, zooals o. a. blijkt door het lidmaatschap der Zweedsche Academie, waar hij von Martils, Hugo von Mohl, Brongniart, Alexander Brayx, Asa Gray, De Candolle en Joseph Dalton Hooker als botanische medeleden had.

Door zijn voorliefde voor tropische plantenfamilies, voor de flora van ons Indië, komt hij met TeysuAvn in aanraking, ontvangt uit Buitenzorg steeds meer materiaal voor zijn onderzoekingen en bewijst omgekeerd aan TEysuans den dienst, zijn plannen bij de Regeering te verdedigen. Want Teysmann wilde groote veranderingen in Buitenzorgs' tuin tot standbrengen, en had daartoe reeds zestien jaar lang gevochten en bij de Indische regeering nota's ingediend, die echter meest onbeantwoord bleven.

In I $85 \mathrm{I}$ was TEysuann begonnen met een memorie over "vele punten den plantentuin alhier betreffende" en in I 862 
begint de Indische regeering, dank zij de geschiedkundige neigingen van den Gouverneur-Generaal SLOET raN de: BeEle, het belang van Tersmanss plannen te begrijpen. In April $186_{3}$ wordt aan den Minister van Koloniën aanstelling van een ",wetenschappelijk gevormden botanicus" gevraagd en op aandrang van Mrquel besluit de minister hiertoe. Weder door Mrǫuef's invloed wordt hiertoe aangewezen de candidaat aan de Utrechtsche Universiteit R. H. C. C. Scheffer, die na voltooiing van zijn studie onder Miquels leiding, in Buitenzorg het ambt van directeur zou aanvaarden en dan eerst ,door Tersmann's rijke ervaring worden voorgelicht". En tegelijk met de benoeming van dezen nieuwen directeur wordt de Plantentuin uit de boeien van het militair régime bevrijd en wordt de Intendant der Gouvernements-Hotels aangeschreven: „om in overleg met den Hortulanus van 's Lands Plantentuin te Buitenzorg, J. E. Tersmann, voorstellen te doen omtrent de afscheiding van het park en den plantentuin".

Teysmanis had volgehouden en overwonnen. 's Lands Plantentuin was herboren!

De nieuwe directeur van den Hortus Bogoriensis was een nog jonge man, maar begaafd met een wilskracht, die hem tot het overwinnen van groote moeilijkheden in staat stelde. Door zijn innemende persoonlijkheid had hij zich de genegenheid van zijn lecrmeester MrQcel verworven: door zijn bescheidenheid en zijn liefde voor planten werd hij meer de vriend dan de chef van den zesendertig jaar ouderen Texsisix.

Scherfer's vader was een energiek en wetenschappelijk hoogstaand geneesheer te Spaarndam, waar Rcdolpir HermaN Christian Carei, i 2 September I 844 geboren werd; achtereenvolgens woonde de familie Scheffer te Spaarndam, Poortugaal, Utrecht en Weesp, totdat Ritolpir in 1862 naar Utrecht terugkeerde, om hier medicijnen en natuurwetenschappen te gaan 
'S LANDS PLANTENTUIN NA 1850.

studeeren. In i 864 legde hij summa cum laude het candidaatsexamen in de wis- en natuurkunde af. Het was op Miquel's raad, dat de jonge Scheffer de toestemming van zijn vader vroeg, om zich op de plantkunde te mogen gaan toeleggen en dan in de toekomst als Directeur van 's Lands Plantentuin op te treden. Zoo gebeurde het ook, met het gevolg, dat RUdulph een groot deel van zijn studietijd in het Leidsche Rijks-Herbarium doorbracht, 20 Maart 1867 promoveerde tot doctor in de wis- en natuurkunde op een dissertatie: „De Myrsinaceis Archipelagi Indici", I5 November I 867 naar Indië vertrok en onderweg op Ceylon den botanischen tuin te Peradenyia bezocht, om met den bekwamen directeur Thivaites kennis te maken.

In Buitenzorg werd Scheffer door den Hortulanus met gastvrijheid ontvangen; meer dan een jaar was 'Teysmann's huis ook dat van zijn directeur. Grooter verschil dan tusschen directeur en hortulanus bestond, is moeilijk denkbaar: Schefrer jong, fijnbesnaard, practisch onervaren, maar wetenschappelijk uitnemend onderlegd, de chef van Teysmann, veel ouder, ruw maar goedhartig, wetenschappelijk een self-mademan, echter met sterk ontwikkelde practische gaven. Maar beiden, directeur en hortulanus, waren mannen van welwillend karakter, beider doel was de ontwikkeling van 's Lands Plantentuin; voor een zaak gaven zij zich en wisten zoodoende elkanders persoonlijkheid te leeren hoogschatten. De hartelijke ontvangst, door Teysmann aan zijn jongen chef bereid, werd door Scheffer niet vergeten: ScheFfer was het, die het initiatief nam tot de warme huldiging van Teysmann bij gelegenheid van diens vijftigjarig verblijf op Java (2 Januari 1880).

Het werk, door Teysmann reeds lang begonnen, werd met kracht voortgezet. Nu 's Lands Plantentuin een geheel zelfstandige instelling geworden was en de beide mannen, op wier schouders 



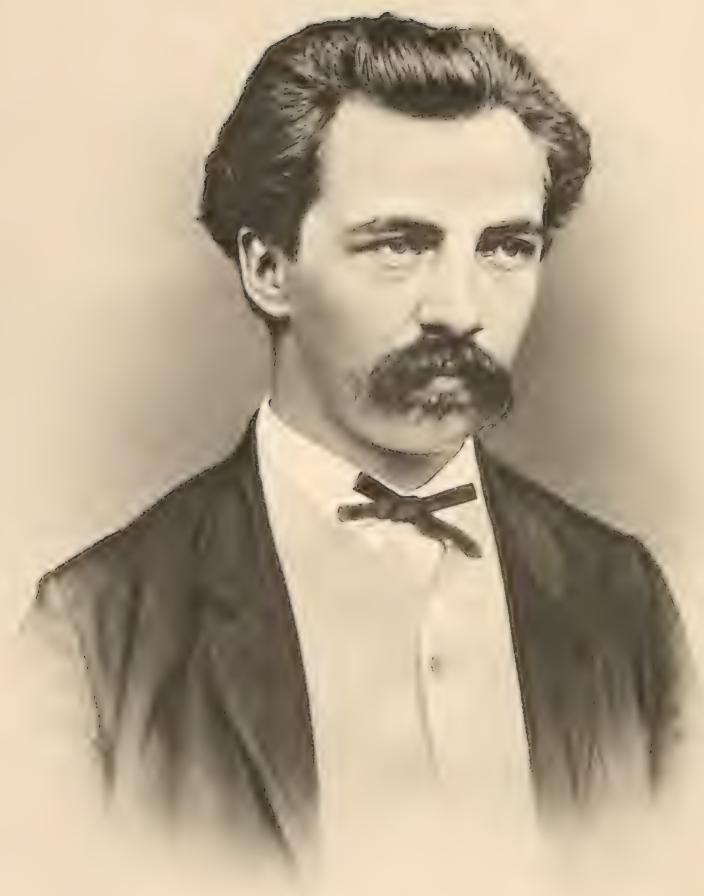

R. H. C. C. SCHEFFER. 
de taak der regeling rustte, door dagelijkschen omgang elkaars gedachten volkomen leerden begrijpen, elkaars plannen leerden kennen, nu werd ook met meer kracht en meer recht bij de regeering aangedrongen op het erkennen van het wetenschappelijk karakter van den Hortus Bogoriensis, op de noodzakelijke uitbreiding van personeel en op een betere verzorging van bibliotheek en herbarium. Na gedurende een jaar sij: jongen vriend te hebben geleid door de eerste moeilijkheden van een zooveel omvattende werkkring, werd TEYSuAnv 22 Januari I 869 eervol ontheven van de betrekking van Hortulanus aan Buitenzorgs tuin en werd hem uitsluitend het doen van wetenschappelijke reizen opgedragen. Vanzelf spreekt, dat het ten opzichte van zijn Plantentuin bij Teysmann niet was: uit het oog, uit het hart, maar dat de scheiding slechts een papieren formaliteit was, teneinde Tersuans meer vrijheid van beweging te geven. En de ruim zestigjarige verlangt nog niet naar rust; het is alsof nu eerst zijn onderzoekingsgeest een geschikt terrein vindt.

Betere verzorging van museum en bibliotheek werd bereikt, doordat het gebouw, waarin de naar Batavia verplaatste directie van het mijnwezen haar bureau had, bij den Plantentuin gevoegrd werd, zoodat het oude houten gebouw, door Tersmins gesticht, verlaten kon worden. En personeelsuitbreiding had ook in 18 ;0 plaats: Texsunxy's plaats werd door Smox Bixnexdyk ingrenomen, terwijl van drie jongelieden, uit Nederland gekomen, er een, de latere hortulanus H.J. Wigmax, toen als Binsexdiys's opvolger aangewezen werd.

Onder Scheffer's beheer werd het terrein te Buitenzorg, door de voortdurende uitbreiding der plantenverzamelingen, al spoedig te klein; een afzonderlijke ruimte voor het nemen van proeven met cultuurgewassen was zeer gewenscht, zoodat plannen gemaakt moesten worden voor mogelijke uitbreiding. Het eenige terrein, waarover beschikt kon worden, was hr:t 
ongreveer drie kwartier van Buitenzorg grelegen Tjikeumeuh, een stuk land ter groote van Io5 bouws, waarvoor de regeering een som van $f 15,000$ toestond, teneinde den huurder af te koopen en het terrein in orde te brengen. In ScIIEffer's verslag over 1876 vinden we dan ook vermeld, dat Tjikeumeuh als ,kultuurtuin” bij 's Lands Plantentuin gevoegd werd, en in I 879 deed zich de noodzakelijkheid voor in dien verafgelegen kultuurtuin een deel der botanisch belangrijke planten uit Buitenzorg onder te brengen. De bergtuinen werden zoo goed mogelijk onderhouden; het vinden van een bekwaam persoon, om de leiding dezer eigenlijk zelfstandige gedeelten op zich te nemen, leverde groote moeielijkheden op; de nog in Tjipannas aanwezige belangrijke planten werden naar een nieuwen bergtuin, het thans nog bestaande Tjibodas overgebracht. Bovendien ondersteunde SCHEFFER krachtig het initiatief van den directeur van Binnenlandsch Bestuur, Mr. H. D. Levyssohn Norman, om in Buitenzorg een landbouwschool op te richten, een ondernemen, dat in 1876 ook met succes bekroond werd.

Voor zoover Scheffer's werkkracht niet door dergelijke organiseerende en administratieve bezigheden werd in beslag genomen, was hij voor het overige genoodzaakt zijn tijd te verdeelen tusschen twee dringende zaken van zeer uiteenloopenden aard: de Indische landbouwbelangen te behartigen en het wetenschappelijk karakter van 's Lands Plantentuin te handhaven. Van beide taken heeft hij zich schitterend gekweten. Het verwijt hem door de regeering in het begin gedaan, dat hij door zijn plannen voor oprichting van een kultuurtuin zou trachten ,zich van de bemoeienis met het practisch gedeelte van den werkkring af te maken" heeft Scheffer door daden weerlegd en was volkomen onverdiend; reeds vanaf 1870 had hij zich bezig gehouden met de verzorging van den kolonialen landbouw; in het verslag over dat jaar treffen wij o.a. mede- 
deelingen aan over proeven met koffie, suikerriet, Eucalyptussoorten, Phormium tenax (Nieuw-Zeelandsch vlas) en zonnebloemen, waaraan een invloed ten goede ten opzichte der in kustplaatsen voorkomende "miasmatische uitwasemingen" werd toegeschreven. In 187 I wordt de verspreiding van Albizziasoorten vermeld, die als schaduwboomen voor koffietuinen ver boven de totnogtoe gebruikte dadap verkieselijk scheen. In het verslag over 1873 betoogt Scheffer de wenschelijkheid op Java Liberia-koffie in te voeren en in 1875 werden planten en zaden ontvangen en kon de cultuur dezer zoo belangrijke koffie-soort een aanvang nemen. Hoezeer Scherfer's bemoeiingen met den landbouw en de verspreiding van nuttige planten zich ontwikkelden, blijkt wel het beste uit den omvang der ,Verslagen omtrent den staat van 's Lands Plantentuin te Buitenzorg", waarvan steeds het grootste gedeelte aan de bespreking van landbouwgewassen gewijd was: het eerste van Scheffer's verslagen (over I868) was 4 bladzijden groot, terwijl zijn laatste (over 1878) 45 bladzijden en 56 bladzijden bijlagen besloeg.

Op de grens van wetenschappelijke en landbouwbotanie ligt een mededeeling in Scheffer's verslag over 1877 (blz. 3 I): „In Augustus schijnt zich voor het eerst op Sumatra te hebben voorgedaan, die ziekte van den koffieheester, die als Ceylonsche coffee-leaf-disease bekend is, en veroorzaakt wordt door een fungus, Hemileia vastatrix geheeten". Het eerste in Buitenzorg verrichte phytopathologisch onderzoek is hiervan het gevolg; adviezen worden gegeven, vooral gebaseerd op het feit, dat goede cultuur het weerstandsvermogen der koffieboomen sterk verhoogt en een beschrijving met afbeelding der ziekte wordt gegeven in het "Tijdschrift voor nijverheid en landbouw in Nederlandsch-Indië" (deel XXII). En in Midden-Java treedt in die jaren een eenigszins raadselachtige koffiewortelziekte op, 
die daar veel koffieboompjes vernietigt en groote schade toebrengt.

Cultuurtuin en landbouwschool waren thans de veeleischende inrichtingen, die ScuEfFER's tijd bijna geheel in beslag namen; hij geeft er met de meeste bereidwilligheid een groot deel van zijn leven aan, al verlangt hij er naar, dat in de toekomst het zwaartepunt weer naar zijn wetenschappelijk-botanisch werk verlegd mag worden. Voor eigenlijke studie blijft hem te weinig tijd beschikbaar; toch slaagt hij erin, een drietal stukken van zuiver botanischen aard te publiceeren ${ }^{\mathrm{x}}$ ).

En in nog een ander opzicht weet Scheffer's initiatief zich te uiten: in 1873 verkreeg hij den steun der Regeering voor de uitgave van een zelfstandige wetenschappelijke publicatie, de later zoo bekend geworden „Annales du Jardin Botanique de Buitenzorg". Het eerste deel, het eenige door Scherfer uitgegeven, verscheen in 1876 . Behalve een reisverslag van Tersmanx en enkele artikeltjes van Binnendijk en Wigmax, bevat dit deel uitsluitend floristische en systematische studies van SCHEFFER zelf: een tweede stuk over palmen, planten van Nieuw-Guinea, enz. Een andere belangwekkende studie over de Anonaceae werd door Scheffer nog wel voltooid, maar verscheen pas in het tweede door zijn opvolger bezorgde deel, terwijl de platen, door Scheffer bestemd voor een nieuwe verhandeling over de palmen van Buitenzorg, door BeCCARI bewerkt en gepubliceerd zijn ${ }^{2}$ ).

I) R. H. C. C. Schefrer, I87o. Observationes phytographicae. I en II. (Nat. Tijdschr. v. N.-I., XXXI. p. I-23 en $338-375$ ).

R. H. C. C. SCHEFFER, I873. Observationes phytographicae. III. (Nat. Tijdschr. v. N.-I., XXXII. p. $387-426$ ).

R. H. C. C. Scherfer, i873. Sur quelques palmiers du groupe des Arécinées, I. (Nat. Tijdschr. v. N.-I., XXXII. p. I49-I93).

R. H. C. C. Scheffer, i876. Idem II. (Annales du Jard. bot. Buitenzorg, I. p. $\mathrm{IO}_{3}-\mathrm{I} 64$ ).

2) O. BeCCARI, I885. Reliquiae Schefferianae Illustrazione di alcune Palme virenti nel Giardino Botanico di Buitenzorg. (Ann. Jard. bot. Buit., II. p. 77-171). 
Ook Schefrer zou een voorbeeld zijn, dat een werkzame en energieke geest in een tropisch land de lichaamskrachten niet overschatten mag. „De ambitie overschreed de grenzen van een menschelijk vermogen en de natuur wreekte zich, tot schade voor de wetenschap, tot een ramp voor dierbare betrekkingen", schrijft zijn vriend Vax Gorkom in r8S0 ${ }^{1}$ ). Scherfer werd in Februari r88o ziek; een acute leverontsteking bleek te ernstig voor geneeskundige hulp. In koele bergstreken, het gezondheidsoord Sindanglaja, zocht hij verlichting maar ook dit mocht niet baten; hij overleed 9 Maart I880, nog geen $3^{6}$ jaar oud.

In Scheffer had 's Lands Plantentuin een directeur verloren, onafgebroken werkzaam in het belang van land en volk, landbouw en wetenschap beide dienend, zooveel hem mogelijk was. "Het was niet een zijner geringste deugden, dat hij met onbegrensden ijver en onverdeelde toewijding aanvaardde en doorzette, wat hij zijn roeping dacht. Daardoor kon hij zoovelen prikkelen tot belangstelling en medewerking, en een geest opwekken, die ook na zijn betreurd verscheiden lang zal blijven voortleven" ${ }^{2}$ ).

Was dus de ontwikkeling van 's Lands Plantentuin na de vrijmaking door Texsmixs, onder Scheffer's leiding reeds een belangrijke, nog veel machtiger ontplooiing toont ons deze instelling in de nu volgende periode. De leidende geest, door wiens geestdriftig werken en durvend initiatief dit bereikt werd, was Scheffer's opvolger, de nog geen dertig jaar oude Melchior Treub.

Het ontstaan van 's Lands Plantentuin, de stichtingsidee,

1) K. IV. vax Gorkon, ISSo. Levensbericht van R. H. C. C. Schefrer. (Jaarb. Kon. Ak. v. Wet. I880. p. I-2I). p. I9.

2) K. W. haN Gurkow, ISSo. Dr. R. H. C. C. Schelfer en 's lands Plantentuin te Buitenzorg. (Eigen Haard, ISS॰. Overdruk). p. 20. 
danken wij aan REINwaRdT's vooruitzienden blik ; de eerste wetenschappelijke fundamenten zijn het werk van Hasskarl; Diard en Teysurann waakten voor zijn behoud onder ongunstige omstandigheden; het innige verband met de practijk der cultures wordt onder Scheffer's beheer gelegd; maar dat de Plantentuin geworden is tot de eerste botanische inrichting der tropische wereld, tot de instelling, waar plantkundigen van alle landen hun kennis komen verdiepen door nauwe aanraking met de tropische natuur, waar verfijnd wetenschappelijk botanisch werk vereenigd wordt met de oplossing van veeleischende en dringende practijk-vraagstukken, dat zal steeds de onvergankelijke beteekenis van TREuB's directeurschap blijven.

Melchior Treub's vader was burgemeester van Voorschoten, waar Melchior als oudste van het viertal kinderen 26 December I 85 I geboren werd en waar hij tot zijn vertrek naar Indië wonen bleef. Eerst bezocht hij daar de lagere school, daarna de H.B.S. te Leiden, waarheen hij iederen dag van Voorschoten kwam wandelen. Maar omdat de wet aan het eindexamen H. B. S. geen waarde hechtte voor universiteitsstudie, deed hij in plaats hiervan het toelatingsexamen voor de universiteit (1869); zijn kennis der klassieke talen had hij aan privaatlessen van den dorpsdokter te danken. Treub vond in zijn studententijd weinig gelegenheid "student te zijn"; hij studeerde en in de richting, waarin zijn wetenschappelijke neiging hem dreef, lagen niet de genoegens van het studentenleven. Reeds vier jaar na zijn inschrijving in het "Album studiosorum", toen hij nog geen 22 jaar oud was, promoveerde Treub op. een dissertatie over een toentertijd zeer actueel onderwerp; hij bracht belangrijke argumenten voor de juistheid van SCHwExDENER's korstmossen-theorie.

$\mathrm{Na}$ zijn promotie werkzaam als assistent aan de Leidsche Universiteit en in zijn avonduren aan "Mathesis", vond hij in 



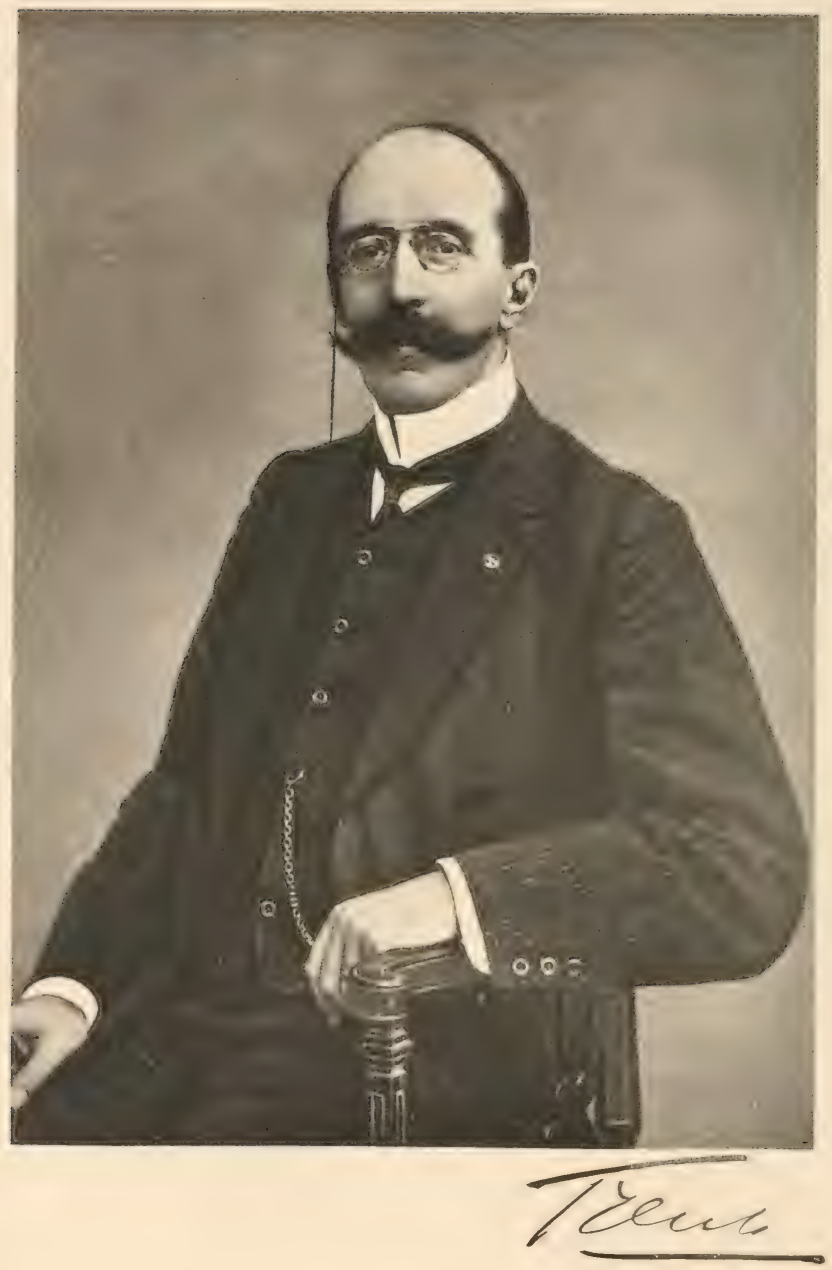

MELCHIOR TREUB. 
deze zes jaar nog ruimschoots gelegenheid tot wetenschappelijk onderzoek: hij publiceerde in dezen tijd anatomische studies over wortelontwikkeling, over Selaginella, physiologische over bladgroen en de rol der bastvezels, embryologische over de embryozak-ontwikkeling bij Angiospermen en vooral by Orchideeën, cytologische over kernkleuring en kernbouw. En bovendien gaf hij ieder jaar in de Revue des Sciences naturelles een overzicht: "La Botanique aux Pays-Bas", een samenvatting van wat ons land aan de vordering der plantkundige wetenschap bijdroeg. TRELB had dus ten volle bewezen, hoezeer hij tot zelfstandig wetenschappelijk onderzoek bekwaam was, en het was dan ook op aanbeveling van alle hoogleeraren in de botanie aan de Nederlandsche Rijks-Universiteiten, dat hem na Scheffer's overlijden het directeurschap van 'sLands Plantentuin opgedragen werd.

De jonge directeur vond in Buitenzorg een zware taak: Scheffer had wel de richting aangegeven, waarin 's Lands Plantentuin zou moeten geleid worden. maar TRELB miste de kundige en welwillende voorlichting van Tersuaxs, die Scheffer bij zijn komst nog een jaar lang ter zijde gestaan had en die in TREUB's tijd bijna voortdurend op onderzoekingsreizen was. De werkkring, die TREUB wachtte was te omvangrijk geworden voor één man: de Regeering besloot dan ook reeds spoedig tot aanstelling van een adjunct-directeur, waartoe TRELB's studiegenoot, Dr. W. Burck in den loop van I 88 r benoemd werd.

In November I8so kwam TReub in Indië aan; den $\mathrm{I}_{3}$ en aanvaardde hij het directeurschap. En onmiddellijk vond zijn werkzame en zeer begaafde geest stof voor arbeid rondom zich; er waren groote en belangwekkende vragen te beantwoorden. TREUB zelf werkte den eersten tijd vrijwel zuiver botanisch, BuRCK later in meer landbouwkundige richting. Door een uitmuntende arbeidsverdeeling kon TRELB zich geheel wijden aan embryologische en physiologische onderzoekingen; B४Rск nam 
het morphologisch-systematische werk voor zijn rekening. TREUB's groote werkkracht stelde hem in staat reeds in 1882 het tweede. deel der "Annales" in het licht te geven, gedeeltelijk gevuld met nagelaten handschrift van SCHEFFE, maar grootendeels bijdragen van Treci zelf bevattend. En voortaan zou bijna ieder deel der „Annales” bewijzen brengen voor Treur's krachtige werkzaamheid en zijn veelomvattenden wetenschappelijken aan$\left.\operatorname{leg}^{\mathrm{x}}\right)$. In het begin waren het vooral bloemen en zaadknoppen in hun ontwikkeling die zijn aandacht trokken: Cycadeeën, als merkwaardige overgangsvormen tusschen Kryptogamen en Phanerogamen van groot belang, Loranthaceeën, een groep woekerplanten, waartoe bijv. ons Vogellijm behoort en waarbij door hun parasitische levenswijze afwijkingen van het normale te wachten waren, Casuarinaceeën, waarbij een hoogst eigenaardig verloop van het bevruchtingsproces (chalazogamie) gevonden werd, voorts Orchideeën en Burmanniaceeën, leverden hiervoor dankbaar en rijk materiaal voor onderzoek, dat alleen in de tropen mogelijk was. Want steeds hield Treub voor oogen, dat natuurwetenschappelijk werk in tropische streken zich beperken moet tot wat alleen in de tropen verricht kan worden, indien we hier tenminste bij een zoo ruim arbeidsveld van ,beperking" spreken mogen. Ook vallen in het eerste tienjarig tijdvak van TREus's directeurschap, den tijd, waarin hij zich het meest aan zijn wetenschap geven kon, waarin zijn administratieve en practijk-beslommeringen hem nog niet zóózeer in beslag namen, de schitterende reeks van onderzoekingen over de ontwikkeling en generatiewisseling der wolfsklauwen. Van enkele tropische Lycopodiumsoorten kon TREUB den ganschen levensloop volgen; het belangrijke feit, dat wolfsklauwvoorkiemen kleurloos en saprophytisch zijn, in tegenstelling met

1) Zie roor titels: F. A. F. C. Went, i9i I. Melchior Treub. (Arn. Jard. bot. Buit., XXIV. p. I-XXVIII en bibliographie. p. XXIX-XXXII). 
varen-prothalliën die bladgroen bevatten en dus zelf hun voedsel kunnen maken, werd door hem ontdekt; hij begreep, dat zoo. doende de Lycopodiaceeën in zekeren zin een overgang vormen tusschen varens met hun zelfstandige prothalliën en phanerogamen waar de geslachtsgeneratie volkomen parasitisch leeft.

Physiologisch onderzoek vinden wij van allerlei aard: een nieuwe groep van klimplanten, die zich met zgn. "haken” vasthechten, gekromde organen van morphologisch zeer verschillende natuur, maar allen overeenstemmend door hun wijze van reactie op aanraking (diktegroei). Voorts is de beteekenis van zetmeel in de melksapvaten van Euphorbia's een onderwerp van studie, en wordt door TRELB aangetoond, dat er geen verband bestaat tusschen de holle gangen in Myrmecodiaknollen en de aanwezigheid van mieren. Later (IS96-I910), publiceert hij in de "Annales" een reeks onderzoekingen van bijzonder belang: de door GRESHofF aangetoonde aanwezigheid van cyaanwaterstof in blaren van Pangium edule is voor hem aanleiding het voorkomen dezer stof in andere planten na te gaan en haar beteekenis voor de eiwitvorming vast te stellen. Helaas zijn deze baanbrekende onderzoekingen onvolkomen gebleven: de afsluiting van dit werk heeft TreuB niet meer mogen zien.

Ook op het gebied van plantengeographie en -oecologie vinden we een belangrijke bijdrage van TRELB's hand: de algeheele vernietiging van Krakatau's plantengroei in $1 \delta_{3}$ was hem een welkome aanleiding, de wederbegroeiing van een door vulkanische uitbarsting volkomen verwoest eiland na te gaan; enkele tochten daarheen, waarvan hij in $\mathrm{I} 888^{\mathrm{I}}$ ) de resultaten publiceerde, gaven hem een inzicht hoe eerst door samenwerking van blauwwieren en verweeringsprocessen de onvruchtbare

1) M. Treul;, isSS. Notice sur la nouvelle flore de Krakatau. (Ann. Jard. bot. Buit., VII. p, 213-223). 
bodem begroeibaar werd gemaakt, hoe in het zoo ontstane dunne waterhoudende laagje varensporen kiemen kunnen en de opgroeiende varenplanten met hun wortels het verweeren begunstigen en hoe zoo de bodem voor hoogere gewassen, wier zaden door wind- en zeestroomen aangevoerd worden, meer geschikt wordt. Wanneer men nu bedenkt, dat Krakatau op een afstand van I 8,5 K.M. verwijderd is van het dichtstbijzijnde eiland Sibesie, terwijl Sumatra 37,1 K.M. in noordwestelijke richting en Java 40,8 K.M. oostelijk ligt, dan blijkt wel uit deze onderzoekingen, hoe grooten invloed wind- en zeestroomingen op plantenverspreiding hebben. Later (I89j) werden door Treub en Penzig voor het eerst planten, wier zaden door vogels aangebracht waren, gevonden ${ }^{\mathrm{I}}$ ), terwijl ERvst nog kort geleden de verdere ontwikkeling van Krakatau's flora beschreven heeft ${ }^{2}$ ), daarbij voor de determinatie der planten geholpen door C. A. BACKer. Thans is het nog geen twintig jaar geleden volkomen dorre eiland weer begroeid met een weelderige tropische flora.

En daartusschen verschenen een aantal mededeelingen voor de practijk in de ,Korte Berichten, uitgaande van den Directeur van 's Lands Plantentuin"; ook een tweetal publicaties met phytopathologischen inhoud over de raadselachtige sereh-ziekte van het suikerriet en over de mogelijkheid, dat ,sereh" door een parasitisch aaltje veroorzaakt zou worden.

Naast al dit onderzoekswerk vinden wij bewijzen van TREus's liefde voor zijn tuin in de "Geschiedenis van 's Lands Plantentuin", een prachtig gedocumenteerde bronnenstudie (1889 3), die

1) Zie O. Penzig, 1902. Die Fortschritte der Flora des Krakatau. (Ann. Jard. bot. Buit. XVIII. p. 92-II4).

$\Rightarrow$ A. ERNST, 1907. Die neue Flora der Vulkaninsel Krakatau. (Viertelj. naturf. Ges Zürich 1907. p. 289-362. Ook afzonderlijk. Zürich, 1907).

3) M. Treub, I889. Zie p. 92, noot $r$. 
echter alleen de eerste periode, tot 1844 bevat en waarvan helaas het beloofde tweede gedeelte nooit verschenen is. Moge de naderende herdenking van het honderdjarig bestaan aanleiding geven deze gaping in de litteratuur aan te vullen!

Wetenschappelijk hoogstaand, met organisatorisch talent en een zeldzame scherpte van blik bij de beoordeeling van personen, die hij pas even ontmoet had, dat was de grootheid van TReub's gaven. Miskenning van de zijde van het groote publiek, wantrouwen van planters deden hem niet van zijn standpunt wijken; steeds wist hij, ongetwijfeld geboren diplomaat in den meest gunstigen zin, het evenwicht te vinden tusschen de eischen van de mannen der practijk en de papieren bezwaren uit de ambtenaarswereld, en toch te zorgen, dat het zuiver wetenschappelijk karakter van zijn Plantentuin bewaard bleef. Thans is het ook algemeen duidelijk geworden hoe groote diensten TReub aan wetenschap en practijk beide bewees: door herhaalde huldebetoogingen en eerbewijzen uit geleerdenkringen, door uitingen van dank, hem o. a. vanwege de Indische suikerplanters gebracht, maar bovenal door de regeeringsdaad, die Treub gelukkig nog beleven mocht, waardoor 's Lands Plantentuin als zelfstandig-wetenschappelijke instelling is hersteld.

Dat het eerste tienjarig tijdvak tot 1890 Treub's meest vruchtbare tijd voor wetenschappelijk werk was, zal niemand verwonderen, die slechts naast elkaar ziet het eerste „Verslag over de verrichtingen van 's Lands Plantentuin" door TREUB uitgebracht over I88I en het ,Jaarboek van het Departement van Landbouw" over I908, het laatste onder TREuB's leiding samengresteld. Uit een eenvoudig verslag, nauwelijks $40 \mathrm{blz}$. groot, is een omvang rijk Jaarboek gegroeid, bijna twaalf maal zooveel bladzijden bevattend.

Toen Treti het ambt aanvaard had en kort na hem Burck als Adjunct-directeur was opgetreden, was in de eerste plaats 
verbeteren en vernieuwen hun werk. De bibliotheek werd gecatalogiseerd, waardoor ze natuurlijk sterk aan bruikbaarheid won; het herbarium werd geheel herzien en verzorgd. Met ruiling en toezending van herbarium- en spiritusmateriaal aan Europeesche geleerden werd terstond een aanvang gemaakt; terwijl Burck reeds in de eerste jaren een belangrijke studiereis naar de Padangsche Bovenlanden ondernam, met de bestudeering van getah-pertjah-leverende boomsoorten als doel. Spoedig (I883) moest Treci ook de hulp van zijn uitnemenden hortulanus, Simon Binsendijk, missen, in wiens plaats de assistenthortulanus H. J. WiGMin gesteld werd, de eenige nog levende, die de gansche ontwikkeling van 's Lands Plantentuin medegemaakt heeft.

Hoezeer het verwijt, aan Treus wel eens gremaakt, dat hij de belangen van den practischen landbouw te zeer uit het oog verloor, onverdiend is, blijkt wel uit het feit, dat hij reeds in r884 een nieuwe geregelde publicatie begon naast de Annales van streng wetenschappelijk karakter, uitsluitend terwille van den landbouw. Het eerste nummer dezer nieuwe uitgave: „Mededeelingen uit 's Lands Plantentuin", bevat de resultaten van Burck's studiereis ten opzichte der getah-pertjah-soorten; van hoe gezonde natuur deze uitgave was, toont ons het aantal dier mededeelingen, dat thans ongeveer een honderdtal bedraagt.

In den ,winter" van I883-I884 (de uitdrukking is van TReub ${ }^{1}$ ) werd aan 's Lands Plantentuin een bezoek gebracht door graaf Von Solus-Lacbach, hoogleeraar te Göttingen, een bezoek van beteekenis, als eerste in een reeks van wetenschappelijke reizen, door Europeesche geleerden ondernomen uitsluitend met het doel op Java en vooral in 's Lands Planten-

د) M. Treub, ISg8. Notice sur l'état actuel de l'Institut, (Bull. de l'Inst. de bot. Buit. $N^{\circ}$. I, I898. 40 pp.). p. 2. 
tuin onderzoekingen te doen. Graaf Solms schreef over zijn reis een waardeerend artikel in de Botanische Zeitung (Nov. en Dec. 1884), een artikel, dat er ongetwijfeld krachtig toe bijgedragen heeft, Buitenzorg's tuin en zijn wetenschappelijke beteekenis bekend te maken, en bij menig Europeesch geleerde het verlangen naar een reis naar Java zal hebben gewekt. Weer was het TREuB'S doorzicht, waaraan in het begin van 1885 de totstandkoming van Buitenzorg's vreemdelingenlaboratorium te danken is, uitsluitend bestemd voor tijdelijke bezoekers. "Het bezoek van buitenlandsche natuuronderzoekers aan ons station, zal niet alleen dienstig zijn om den goeden naam van 's Lands Plantentuin te helpen ophouden; ook onze "Annales" kunnen, bij verwezenlijking mijner verwachtingen, menige belangrijke bijdrage tot de kennis en de levensgeschiedenis van tropische planten, van de hand van bekwame mannen, tegemoet zien" "). In het buitenland werd dit feit zeer gewaardeerd; een in 1892 bij het 75-jarig bestaan van den Plantentuin door Goeber, Haberlandt, Karsten, Schimper, Selenka, Solms-Lalbach, Stanl, Strubell, Tschirch en Warburg geteekende oorkonde, geeft er schitterend getuigenis van: „Aus kleinen Anfängen, sich mühsam emporarbeitend hat er in diesem Zeitraum eine mehr und mehr wachsende Bedeutung für die Wissenschaft erlangt und steht jetzt als ein leuchtendes Vorbild da für ähnliche wissenschaftliche Anstalten der Tropenwelt". En dat hum wensch: „Möge der weitschauende Geist der Liberalität unter dessen Schutze allein ein reiches wissenschaftliches Leben sich $z u$ entfalten vermag, stets dort einheimisch bleiben zu Nutz und Frommen der Völker vereinenden Wissenschaft", dat deze wensch zoo volkomen in vervulling gegaan is, dat is Treub's werk.

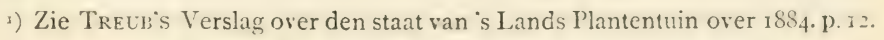


'S LANDS PLANTENTUIN NA 1850.

Kenmerkend voor Treub's ruime opvattingen is het, dat in dit vreemdelingenlaboratorium niet angstvallig alleen botanisch onderzoek werd verricht, maar dat ook zoölogen, als HAECKEI, Selenka, Semox en Max Weber er een werkplaats vonden. Haberlandt's „Botanische Tropenreise” ") en Massakt's „Un Botaniste en Malaisie" ") brengen grooten lof aan Buitenzorg's instelling en haar beheerder. Maar Treub begreep, dat voor een Europeesch botanicus een reis naar het verre Oosten vaak om finantiëele redenen onbereikbaar zal zijn en hij wist weer het middel te vinden, hieraan tegemoet te komen. Tijdens zijn eerste verlof wegens ziekte (TREci is drie maal een jaar in Europa geweest: I887-'88, I895-'96 en 1902-'O3) wist hij van particulieren een som van $f$ I5.000,- bijeen te krijgen, die als "Buitenzorg-fonds" aan de Koninklijke Academie van Wetenschappen te Amsterdam in beheer is overgedragen. Een

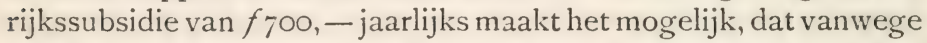
het Buitenzorgfonds eenmaal in de twee jaar een botanicus kan uitgezonden worden, om vier maanden lang in den Plantentuin onderzoekingen te doen. Reeds dertien keer is zoodoende aan een plantkundige een reis naar den Hortus Bogoriensis mogelijk gemaakt. Andere landen volgden dit voorbeeld: thans bestaan in Duitschland, Rusland, Zwitserland, Oostenrijk en België studiebeurzen voor hen, die in Buitenzorg willen gaan werken. Is het te verwonderen, dat de "Annales" door de talrijke bijdragen dier geleerden zijn geworden tot het meest belangrijke botanische tijdschrift der tropen? En bovendien hebben de opvattingen in de plantkunde een grondige herziening ondergaan. „Er wordt thans wel degelijk rekening mee gehouden, dat de meest volmakte ontwikkeling van het plantenleven alleen in de landen

1) G. Haberlandt 1893. Eine botanische Tropenreise. Indomalaïsche Vegetationsbilder und Reiseskizzen. Leipzig, I893.

2) J. Massart, 1895. Un Botaniste en Malaisie. Gent, 1895 . 
'S LANDS PLANTENTUIN NA I850.

bij den Evenaar gevonden wordt; de plantkunde is van een wetenschap, die zich beperkte tot Midden-Europa en de Vereenigde Staten van Noord-Amerika, tot een wereldwetenschap geworden" ").

TREuB's Europeesch verlof van I 887 had, behalve de stichting van het Buitenzorg-fonds nog een ander gunstig resultaat voor 's Lands Plantentuin; op initiatief van den Utrechtschen Hoogleeraar Wefers Bettink besloot Treub pogingen te doen, een militair-apotheker aan den tuin te verbinden, teneinde een onderzoek te beginnen naar de scheikundige eigenschappen van Indische nuttige planten. Dat zulk een studie resultaten zou opleveren, was te verwachten na de onderzoekingen van den apotheker J. F. Eyknan, thans hoogleeraar te Groningen, die als hoogleeraar der universiteit Tokyo drie maanden in Buitenzorg werkte. Het was een zeer gelukkige omstandigheid, dat juist in dien tijd een begaafd jong militair-apotheker, Dr. M. Greshoff, van wien zijn leermeester Prof. Wefers BEtTink getuigde, dat hij ,,bij zijne opleiding te Utrecht blijken gaf van meer dan gewonen ijver en van aanleg tot het doen van zelfstandige onderzoekingen", naar Indië vertrok. Want GRESHOFF's werk is niet zoozeer door zijn arbeid in Indië zelf vruchtdragend geweest (hij was door ziekte genoodzaakt na ruim 4 jaar Indië te verlaten), maar doordat hij in dien korten tijd voor Indië liefde heeft opgevat, en hij, in Europa teruggekeerd, eerst als chemicus, daarna als onder-directeur en na VAN Eedexs dood (I9OI) als directeur de belangen van het Koloniaal Museum zoo warm heeft verdedigd.

Van groot belang voor den Plantentuin was het jaar 1890 : allereerst had Treur van de depressie in de suikercultuur en het steeds meer optreden der sereh-ziekte gebruik gemaakt, om

i) F. A. F. C. Went. igir. Melchior Trecti. (Mann. en Vrouw. v. beteek. XLI. afl. 9). p. 21. 
van de Regeering de aanstelling van twee nieuwe ambtenaren te verkrijgen, nl. een plantkundige, belast met het onderzoek naar de levensvoorwaarden en de ziekten der cultuurplanten en een scheikundige, wien landbouwscheikundig onderzoek en het beheer van den cultuurtuin te Tjikeumeuh werd opgedragen. Als plantkundige werd benoemd Dr. J. M. JANSE, als scheikundige Dr. P. van Romburgh. Nu was de mogelijkheid geschapen voor bijzondere practische vragen langs wetenschappelijken weg een oplossing te zoeken; thans konden alle aan de Regeering uitgebrachte adviezen op wetenschappelijk onderzoek gebouwd worden.

De aanstelling van deze beide onderzoekers was voor TRELI; aanleiding, het geheele beheer van 's Lands Plantentuin te reorganiseeren; terwijl hij een nieuw werkreglement ontwierp, werden zes afdeelingen gevormd, ieder onder een afzonderlijken chef. De eerste dier afdeelingen, omvattend herbarium en museum, werd onder het beheer van den Adjunct-Directeur Dr. Burck gesteld; de tweede, de botanische laboratoria met inbegrip van het vreemdelingenlaboratorium, onder leiding van den plantkundige Dr. JANSE; de derde, waartoe cultuurtuin en landbouwscheikundig laboratorium behoorden, onder Dr. VAN Romburgh; van de vierde, het pharmacologisch laboratorium, werd Dr. Greshoff afdeelingschef; de vijfde, plantentuin en bergtuin, bleef hortulanus Wigman beheeren, terwijl Dr. Treub zelf de leiding van de zesde afdeeling: bureau, bibliotheek en photographisch atelier behield.

Voorts verkreeg 's Lands Plantentuin in datzelfde zegenrijke jaar I89o een belangrijke uitbreiding; het plaatsgebrek, reeds sedert lang een bron van groote moeilijkheden, was zoo nijpend geworden, dat de regeering wel moest toegeven. Een stuk grond tusschen de beide armen der Tjiliwong, ter grootte van ruim elf hectaren werd bij den tuin gevoegd; o.a. werd hierdoor 
ook een veel betere verzorging van waterplanten bereikt. Van grooter belang nog was de toevoeging van 283 hectaren oerwoud aan den bergtuin te Tjibodas; Treub wist van de regeering de toezegging te verkrijgen, dat dit stuk bosch reikend tot aan den Gedeh-krater, onaangetast zou blijven. En om van bergtuin en oerwoud zooveel mogelijk profijt te kunnen trekken, wilde TREUB er een klein eenvoudig gebouwtje stichten, waar bezoekers zouden kunnen werken en overnachten. Maar hiermee was de regeering het niet eens: herhaaldelijk had TREub zijn plannen verdedigd en zijn bescheiden wenschen medegedeeld, maar de ambtenaarswereld beschouwde een dergelijke uitgave als luxe. Totdat bij Treub de diplomaat weer te hulp kwam, en hij aan de regeering verzocht hem de deuren en vensters en afbrakkresten van het te Tjipannas (een uur gaans van Tjibodas) gesloopt wordend buitenverblijf van den G.-G. af te staan en hem te vergunnen, met hulp van den te Tjipannas aanwezigen ingenieur en het werkvolk, zijn laboratorium te stichten. Zoo is het kleine, in de geheele botanische wereld roemrijk bekende gebouwtje met zijn werkzaal, zijn vier slaapkamers en zijn keuken, tot stand gekomen (I $89 \mathrm{I}$ ).

Als laatste aanwinst voor I $\$ 90$ valt nog te vermelden de oprichting van het half-officieele tijdschrift „Teysmannia”, waarvan hortulanus Wigman de redactie voerde en waaraan Treub steun verleende, o.a. door telkens de „Korte berichten, uitgaande van den Directeur van 's Lands Plantentuin" ter opname af te staan.

Het jubeljaar 1892 , waarin op eenvoudige wijze het 75 -jarig bestaan der bloeiende inrichting werd herdacht, was weer een jaar van uitbreiding; het onderzoek der boomflora, door den houtvester KonRDERs in dienst van het boschwezen begonnen, en waarbij van den aanleg der noodzakelijke paden in Tjibodas' oerwoud een dankbaar gebruik gemaakt werd voor het ver- 
'S LANDS PLANTENTUIN NA I 850.

zamelen van materiaal, werd bij 's Lands Plantentuin ondergebracht. KoORders werd daartoe bij den plantentuin gedetacheerd, terwijl hem een plantkundige, Dr. VAleton, werd toegevoegd voor de bewerking der wetenschappelijke resultaten. De „Bijdragen tot de kennis der boomsoorten op Java" van Koorders en VALETON $^{1}$ ) toonen de vruchten van dezen uiterst belangrijken arbeid, terwijl de mikroskopische bouw dier houtsoorten in het Botanisch Laboratorium te Groningen bewerkt wordt door H. H. JANssonius ${ }^{2}$ ). Later (i 894) werd het laboratorium voor boomflora als zevende bij de andere afdeelingen gevoegd en KoORDERs tot afdeelingschef benoemd.

Van groote beteekenis voor den Plantentuin waren nog de jaren I897 en 1898. Een nieuw bibliotheekgebouw, een geschenk van vrienden uit Holland, die aan Treub voor dat doel een som van $f$ I 8,000 aanboden, werd opgericht; de ,Koninklijke Natuurkundige Vereeniging" te Batavia besloot tegelijkertijd haar bibliotheek van ongeveer 16000 deelen naar Buitenzorg over te brengen, waar ze in het nieuwe gebouw een gastvrije ontvangst vond.

En daarnaast beginnen in deze jaren drie periodieke Buitenzorgsche uitgaven hun leven: de Icones Bogorienses, bezorgd door Boerlage, Koorders en Valeton, later ook door Smith, het „Bulletin de l'Institut Botanique de Buitenzorg”, waarvan TrEuB als eerste nummer een ,Notice sur l'état actuel de l'Institut' laat verschijnen met alle noodige inlichtingen voor komende bezoekers en een ,Flore de Buitenzorg”, een hulpmiddel, uit den aard der zaak nog zeer onvolledig, voor vlugge

1) S. H. Koorders en Th. Valeton, IS94-19r4. Bijdragen tot de kennis der boomsoorten op Java, I-I3. (Med. 's Lands Plantentuin, XI, XIV, XVI, XVII, XXXIII, XL, XLII, LIX, LXI, LXVIII. Med. Dept. v. Landb. No . 2. xo, I8;:

4) H. H. Janssonius, 1906-19... Mikrographie des Holzes der auf Java vorkommenden Baumarten. Unter Leitung von J. W. MoLL. Leiden, 1906. Band I-III (nog onvoltooid). 
orientatie in den plantengroei, vooral aan Buitenzorg's omgeving. Tot zoover was de geheele uitbreiding van 's Lands Plantentuin van streng-wetenschappelijken aard, al waren er reeds enkele teekenen, die er op wezen, hoe de ontwikkelingsrichting meer en meer landbouwkundig, dus toegepast wetenschappelijk werd. Reeds tijdens Treub's eerste verlof had Burck aan den steeds toenemenden drang der praktijk-vraagstukken geen weerstand kunnen bieden, en had zich op landbouwkundig-botanische onderzoekingen toegelegd; de personeelsuitbreiding van I 890 was een tweede stap in die richting en wat er na de stichting van het herbarium voor de boomflora nog aan 's Lands Plantentuin werd toegevoegd: de afdeelingen voor Deli-tabak, voor koffiecultuur, voor landbouwzoölogie, voor thee, voor geologisch en bacteriologisch grondonderzoek, voor landbouw- en handelsanalyses, al deze inrichtingen waren door eischen der praktijk in het leven geroepen.

De kern van 's Lands Plantentuin verdween langzamerhand in de jaren $\mathrm{I}_{9} 92$ tot $\mathrm{I}_{905}$ in een omhulling van laboratoria voor landbouwkundig werk; in 1905 kreeg de zoodoende enorm uitgebreide instelling haar officiëele herdooping in ,Departement van Landbouw". Toch had de krachtige, door TREub doorgevoerde, centralisatie van landbouw-proefstations haar groote nadeelen: de meeste cultures waren te ver van Buitenzorg verwijderd, zoodat de onderzoekers te veel het verband met de practische toepassing van hun werk misten.

Uit de eenvoudige instelling, door TREub in ISSO aangetroffen, heeft zich door zijn initiatief en zijn ruime opvattingen een instituut ontwikkeld, waarop ons land trotsch mag zijn. TReub zelf zegt zoo juist in de redevoering, door hem gehouden bij de herdenking van het 75 -jarig bestaan van 's Lands Plantentuin: „In de werken des vredes ligt de kracht en spruit het aanzien voort van kleine volkeren. En waar deze, zooals bij 
ons het geval is, tevens heerschers zijn over eene groote en schoone kolonie, daar voegt zich bij die overweging nog eene andere, en wel: „royauté oblige"”" $)$.

Landbouwbevordering is een veel beteekenende roeping van 's Lands Plantentuin geweest; thans, nu de technische afdeelingen van het Departement van Landbouw en de proefstations deze grootsche taak hebben op zich genomen, moge het oorspronkelijk werk in den herstelden zelfstandigen Plantentuin, het wetenschappelijk-botanisch onderzoek van onze koloniën, de verdieping der plantkundige wetenschap door erkenning van de waarde van onderzoekswerk in de tropen, het ideaal waaraan TREub zich steeds meer heeft moeten onttrekken, weer opbloeien tot voorbeeld van dingen, waarin ,ook een klein land groot kan zijn".

Een overzicht van de resultaten in deze dertig jaren onder TREuB's bestuur bereikt, zou ò te oppervlakkig ò te omvangrijk worden; slechts enkele onderwerpen uit de door Treub, zijn staf en zijn gasten gepubliceerde verhandelingen kunnen hier genoemd worden. De mooie onderzoekingen van TREUB zelf zijn reeds kort vermeld.

Dat systematische onderzoekingen over Indische planten evengoed in Europa gebeuren kunnen, mits maar voldoende en goedbewaard herbariummateriaal ter beschikking staat, bewezen de mooie studies van Miquel; evenzoo getuigen hiervoor de nauwkeurige bestudeering door Dozy en Molkenboer van de Javaansche mosflora ${ }^{2}$ ), door vAN DEN Bosch van de Javaansche

1) M. TReub, 1892. De beteekenis van tropische botanische tuinen. Redevoering, gehouden op i8 Mei i892. Batavia, 1892. p. 28.

2) F. Dozy et J. H. Molkenboer, I844. Musci frondosi ex Archipelago

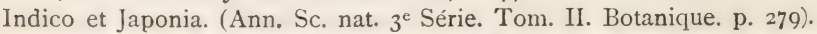

F. Dozy et J. H. Molkenborr, i844. Muscorum frondosorum novae species ex Archipelago Indico et Japonia. (Leiden, I844).

F. Dozy et J. H. MolKenboer, I $845-1848$. Musci frondosi inediti Archipelagi 
Hymenophyllaceae (een groep der varens) ${ }^{2}$ ), door v. D. SAnte LACoste van de Javaansche levermossen ${ }^{2}$ ), en bovenal van Boerlage, die na een korte studiereis naar Indië ( 14 April4 Aug. 1888) als conservator van 's Rijks Herbarium te Leiden, een ,Handleiding tot de kennis der Flora van NederlandschIndië" 3) bewerkte. In I 892 , na Burck's benoeming tot wetenschappelijk adviseur der koffiecultuur, had TRELB tevergeefs gepoogd Dr. J. G. Boerlage tot vertrek naar Buitenzorg over te halen. Later, na Treub's tweede verlof (1896) zien we ook Boerlage naar Buitenzorg komen om de reeds lang vacante plaats van chef der Ie afdeeling te vervullen, een werkkring, waaraan BoERLAGE zich met geheel zijn persoonlijkheid gaf, maar waaraan hij in 1899 op den terugkeer van een studiereis naar de Molukken, door den dood ontrukt werd. Tijdens zijn verblijf in Indië heeft BOERLAGE hard gewerkt, o. a. was hij een der leiders van de nieuwe Buitenzorgsche uitgave: „Icones Bogorienses".

In Indië zelf was het Herbarium met zijn vier afdeelingen : Herbarium generale, Herbarium horti, Herbarium laboratorii en Herbarium Bogoriense, en het Museum voor systematische

Indici, sive Descriptio et adumbratio Muscorum frondosorum in insulis Java, Borneo, Sumatra, Celebes, Amboina nec non in Japonia nuper detectorum. (Leiden, $1845-1848$ ).

F. Dozy et J. H. Molkeneoer, 1S55-1870. Bryologia Javanica seu descriptio Muscorum Frondosorum Archipelagi Indici iconibus illustrata, post mortem auctorum edentibus R. B. v. D Bosch et C. M. v. D. Sande Lacoste. Amsterdam, $\mathrm{s} 855-1870.2$ vol.

1) R. B v. D. Bosch, I86r. Hymenophyllaceae Javanicae, sive descriptio Hymenophyllacearum Archipelagi Indici. (Amsterdam, 186r. Verh. K. A. v. W. Amst. IX).

2) C. M. v. D. SAnde Lacoste, I856. Synopsis Hepaticarum Javanicarum, adjectis quibusdam speciebus Hepaticarum novis extra-javanicis. (Amsterdam, I856. Verh. K. A. v. W. Amst. V).

3) J. G. Boerlage, 1890-1900. Handleiding tot de kennis der Flora van Nederlandsch-Indië, I, II en III. I ${ }^{\mathrm{e}}$ stuk, (niet verder verschenen. Leiden, IS901900). 
botanie, na Boerlage's dood onder leiding van Dr. Thi. Valetox Sr., de werkplaats der systematici; mooi werk werd hier geleverd door V.lLeton zelf, door zijn conservatoren Dr. J. J. Simtu JR., C. A. Bacher, C. W. R. K. v. Alderwerelt r. Rosenburgh en door den houtvester Dr. S. H. Koorders en door ,vrijwilligers”, zooals Mevr. Dr. A. Weber-van Busse over de algenflora.

Dank zij het uitvoerig floristisch onderzoek, is zoodoende de kennis van den plantengroei van Indië's eilanden een vrij diepe en goed gegrondveste wetenschap geworden, een vak van onderzoek, dat niet alleen om de bereikte resultaten op zichzelf van belang is, maar dat de onmisbare basis is, waarop een andere, niet minder aantrekkelijke, studierichting steunt. Dat is de plantengeographie van Ned. Indië.

Als resultaat van zijn studiën over de flora's van NieuwGuinea en Celebes kwam WArburG ${ }^{\mathrm{x}}$ ) tot de conclusie, dat de „lijn van WALLACE" in ieder geval, voor zoover de flora betreft, alle geldigheid mist, dat weliswaar Celebes een zeer rijke endemische flora bezit, maar dat de plantengroei van dit eiland, evenals die van Nieuw-Guinea en tusschenliggende eilanden, een onmiskenbare overeenkomst vertoont met dien van den Indischen Archipel. De Indische eilanden zouden met NieuwGuinea $96 \%$ der niet endemische soorten gemeen hebben: Australië daarentegen slechts $38 \%$. Door uitvoerige bestudeering van het door de ELBERT-expeditie ${ }^{2}$ ) meegebrachte floristische materiaal, is HALLiER ${ }^{3}$ ) nog kort geleden tot dezelfde uitspraak

r) O. IVarburg, I89I. Flora des Monsungebietes. Verh. Gesellsch. deutsch. Naturf. u. Aerzte, I89r.

O. Warburg, 1891. Beiträge zur Kenntniss der papuanischen Flora. Botan. Jahrb. her. v. ENGLER, r89i. XIII. p. 230-455.

2) Zie p. I8r.

3) H. Hallier, r9i2. Die Zusammensetzung und Herkunft der Pflanzendecke Indonesiens. (In: J. Elbert. Die Sunda-Expedition des Ver. Geogr. u. Stat. II. Frankf. a. M., I912. p. 275-302). 
gekomen. Toch kunnen wij ook deze zeer voorzichtig gestelde beschouwingen niet zonder eenig voorbehoud aanvaarden; de floristische kennis der buitenbezittingen, vooral van Nieuw Guinea, is nog dermate in haar beginperiode, dat iederen dag belangrijke nieuwe ontdekkingen verwacht kunnen worden, waardoor schijnbaar vaststaande theorieën misschien allen steun verliezen. En bovendien mogen dergelijke vèrstrekkende conclusies eigenlijk niet getrokken worden voordat van de geschiedkundige plantengeographie, de studie der plantenfossielen, meer bekend is.

Een meer speciaal, maar daardoor veel verder uitgewerkt en minder hypothetisch phytogeographisch onderzoek is dat van SCHIMPER ${ }^{\mathrm{D}}$ ) over de belangwekkende strandflora der Indische eilanden. Onze Archipel met zijn naar verhouding zeer uitgestrekte kustlengte, bood hem daartoe een zeldzaam studieterrein. Op het voetspoor van Junghunn onderscheidde Schinper in de Indische strandbegroeiing een viertal verschillende formaties: de Mangrove-formatie, de eigenaardige grootendeels uit Mangrove's bestaande plantengroei van den vloedgordel, de strook land, die bij vloed door de zee bedekt wordt en bij eb droog loopt, aan welke formatie ook KARSTEN ${ }^{2}$ ) een keurige monografie gewijd heeft, de Nipa-formatie in minder zouthoudende moerassen nabij de zee, die slechts door de hoogste vloeden bereikt werden, voornamelijk gekenmerkt door het voorkomen van Nipa, de Barringtonia-formatie, een boschgroei vlak boven de branding aan steile rotsachtige kusten, waarin vooral Barringtonia-soorten overwegend zijn, en de Pescaprae-formatie, een armoedige flora bijna zonder boomen, ongeveer te vergelijken met onze duinflora. Ook op het gebied der plantenoecologie,

I) A. F. W. Scmimper, iSgr. Botanische Mitteilungen aus den Tropen, III. Die Indo-Malayische Strandflora. Jena, r891.

2) G. Karsten, isor. Ueber die Mangrove-Vegetation im Malayischen Archipel. (Bibliotheca botanica, Heft 22). 
de studie der betrekkingen tusschen planten en hun omgeving, leverde het werk van Schimper mooie resultaten op; de eigenaardige "halophytische" bouw der strandplanten toont groote overeenkomst met die van woestijnplanten, een inrichting die volgens Schimper haar oorzaak vindt in het hooge zoutgehalte van het water, waarover de wortels beschikken en die voornamelijk beperking der verdamping ten doel heeft.

De eerste bezoeker van 's Lands Plantentuin, de Göttingsche hoogleeraar H. Graf zU Solms-Laubach, die van October $188_{3}$ tot Maart I 884 in Buitenzorg vertoefde, verrichtte hier mooie onderzoekingen ${ }^{\mathrm{x}}$ ) over bouw en ontwikkeling van een paar belangwekkende plantensoorten: Psilotum flaccidum en triquetrum, in vele opzichten een overgangsvorm tusschen recente Lycopodiaceae en fossiele Sphenophyllaceae. Verder moeten zijn mycologische studiën en zijn werk over bloemenbiologie en geslachtsdifferentiatie bij vijgen en over den oorsprong der meloenboom, Carica Papaya, vermeld worden. De ,Morphologische und Biologische Studiën" van Goebel, evenals zijn „Pflanzenbiologische Schilderungen" bevatten ook grootendeels waarnemingen, door den schrijver tijdens zijn verblijf in Buitenzorg gedaan (November 1885-Maart 1886); de Annales waren ook nu het tijdschrift, waarin zijn resultaten, vooral in het begin, gepubliceerd werden. Van Burck's verhandelingen is vooral van beteekenis die over de kleistogamie in verband met de wet van KNIGHT-DARIwin, waarin de schrijver het voordeel van kruisbestuiving voor het behoud eener soort boven zelf bestuiving ontkent op grond van het zeer verspreid voorkomende verschijnsel van kleistogamie, d. w. z. zaadvorming in bloemen, die nooit opengaan en dus gedwongen zijn hun eigen stuifmeel te gebruiken; verder die over myrmecophilie, het voorkomen van mieren in en op planten, waarin langen tijd een doelmatige

r) Zie voor de titels der verhandelingen vóor I892: J. MI. JANSE, I892. 



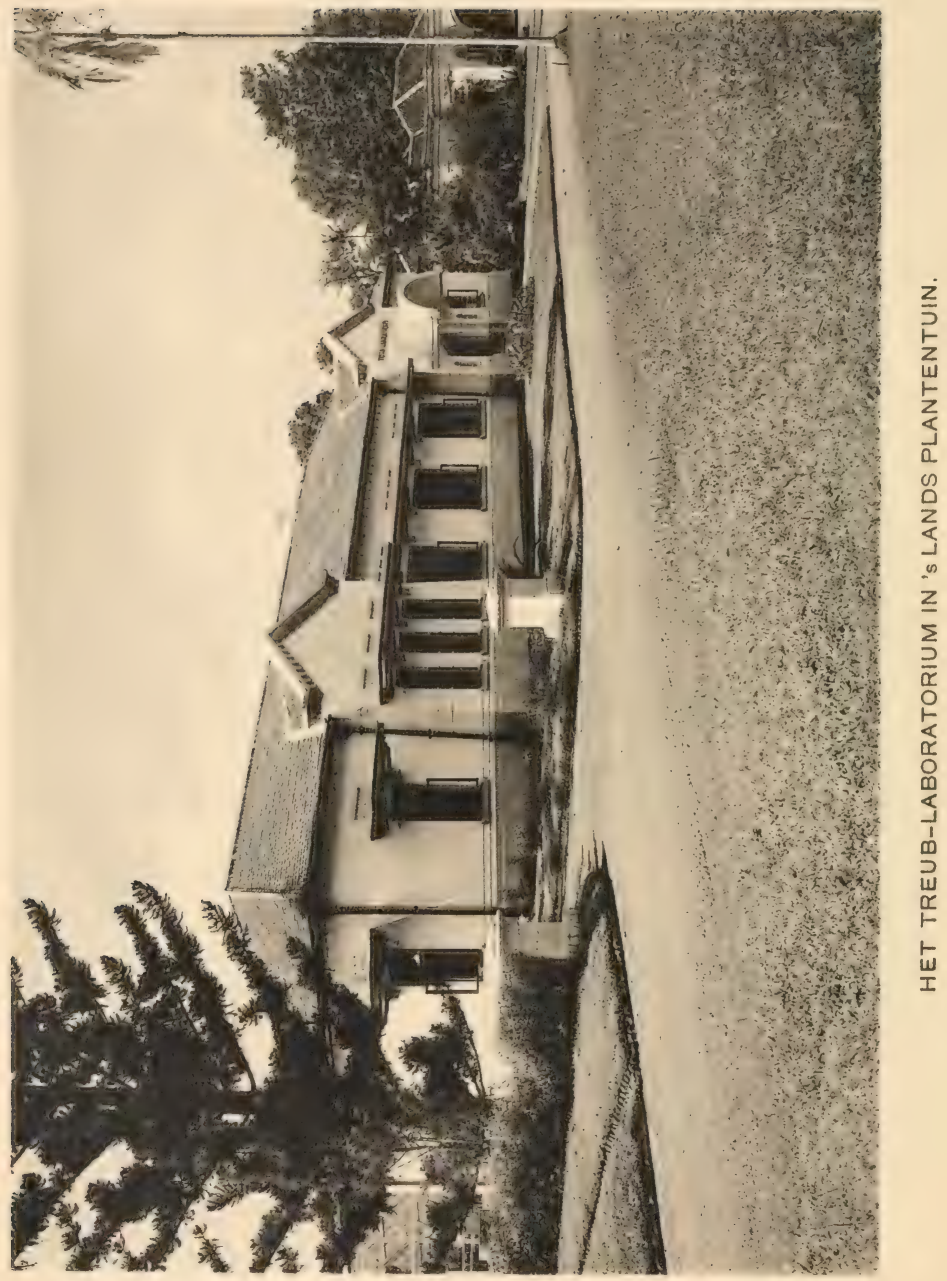


inrichting, een geval van mutualisme, gezien werd. Uit Burck's onderzoekingen bleek er werkelijk een soort wederkeerig dienstbetoon te bestaan; het oorspronkelijke, historische voorbeeld van myrmecophilie, dat van Myrmecodia echinata, waarvan de knollen door mieren doorboord en bewoond zouden worden, verloor door TRELr's onderzoek zijn geldigheid. GREshofF's alcaloïd-onderzoekingen zijn van meer chemischen aard; zijn ontdekking van cyaanwaterstof in de blaren van Pangium edule is echter van vèrstrekkende gevolgen geweest ${ }^{\mathrm{I}}$ ).

Ten slotte mogen nog vermeld worden de algenstudiën van Karsten, het biologisch werk van Stahl, teratologische onderzoekingen van Costercs, pharmaceutische van TsciIrci, physiologische van WENT, embryologische van Lotsr, terwijl een groot aantal verhandelingen van jongeren datum ongenoemd moeten blijven.

Dank zij TRECr is het botanisch onderzoek in Buitenzorg niet meer in hoofdzaak floristisch en is 's Lands Plantentuin de werkplaats geworden van talrijke onderzoekers, die allen daar voor hun speciale studievak gelegenheid tot arbeid vonden. TreciB moge in een oogenblik van ontstemming zich de woorden: "Nul n'est prophète dans son propre pays" hebben laten ontvallen, wij allen, die na hem komen, weten, dat dit op hem geen betrekking had, en hij zelf heeft gelukkig ook nog de zooveel mooiere waarheid leeren kennen. Wij weten, dat er in Buitenzorg een propheet geleefd heeft, baanbreker voor steeds dieper wordende studie der tropische natuur, vooruitziende de groote beteekenis in het leven onzer natie en in de ontwikkeling der botanische wetenschap voor 's Lands Plantentuin weggelegd, en dat die propheet was Melchior Treub.

Zijn geestkracht was het teeken, waarin het gansche jongerc botanisch onderzoek van Oost-Indië stond.

ז) Zie p. 199. 


\section{HOOFDSTUK VIII.}

\section{De studie der dierenwereld na 1850.}

Faunistiek, de orienteeringsarbeid der zoölogie, vond ook in dezen tijd in onze tropische bezittingen uitnemende vertegenwoordigers. In een vorig hoofdstuk leerden wij reeds de werkzaamheid van den officier van gezondheid Dr. P. BLEeker kennen, wiens zeer nauwkeurige ichthyologische studiën de groep der visschen tot de best bekende der Indische fauna gemaakt hebben.

BLEEKER's groote kracht lag ongetwijfeld in zijn vermogen tot zelf beperking; wel was de algemeene tropische fauna voor hem van een groote en steeds grooter wordende bekoring, maar hij begreep, wat velen vóór hem, toen het gansche veld van onderzoek nog ontgonnen moest worden, niet hadden kunnen zien, dat het terrein voor één menschenleven veel te omvangrijk was; dat thans, nu de geheele fauna in groote trekken bekend was, speciale studiën over een afgesloten diergroep vereischt waren; dat nu een aanvang gemaakt moest worden met monographischen arbeid. Reeds van het begin af aan heeft hij zich toegelegd op bestudeering van Indische visschen, en dank zij de ongeveer 500 verhandelingen van zijn hand is de vischfauna van Java thans goed bekend. Er heeft in wetenschappelijke 
kringen een mode geheerscht, laag neer te zien op systematischfaunistischen arbeid, en deze mode is nog niet geheel verdwenen. En toch is deze mode een geheel onrechtvaardige. Men bedenke toch, hoe nauwkeurige soortbeschrijving een steunpilaar voor latere onderzoekingen zijn kan, hoe ook DARWIN door soortbeschrijving tot zijn ideeën gebracht werd; zijn nauwkeurige systematische vormenstudiën over de Cirrhipediën (Rankpootigen), het merkwaardige endemisme op de Galapagos-eilanden van een I3-tal vinkensoorten van het geslacht Geospiza, het waren alle belangrijke factoren in den ontwikkelingsgang van DARIwiv's evolutie-idee. Maar aan den anderen kant mag de systematicus de waarde van zijn uitwendig-morphologische studiën, die soms met inwendig anatomische gecombineerd worden, niet overschatten; het verschil tusschen erfelijke en niet-erfelijke afwijkingen in lichaamsbouw blijkt uit zijn werk niet; het probleem van het ontstaan der nieuwe vormen vermag zijn arbeid niet op te lossen.

Eerst publiceerde BLEeker zijn mededeelingen in zijn .,Archief”, daarna vooral in de „Verhandelingen v. h. Bataviaasch Genootschap” en nog later werd het „Nat. Tijdschr. v. Ned.-Indie”" het orgaan, dat zijn wetenschappelijke bijdragen een plaats verleende, zooals ook de ,Verhandelingen der Koninklijke Natuurkundige Vereeniging". Na zijn terugkeer in het Vaderland (I 860) publiceerde hij vooral in de "Verslagen en Mededeelingen” en de "Verhandelingen" der Koninklijke Akademie van Wetenschappen te Amsterdam, in de „Natuurkundige Verhandelingen” van de Hollandsche Maatschappij van Wetenschappen te Haarlem, de "Archives Neerlandaises" dezer Maatschappij en het "NederTijdschrift voor de Dierkunde" ").

In de eerste jaren van zijn verblijf in de tropen vatte hij het plan op, buiten zijn verspreide kleinere publicaties, ook een

2) Zie P. Bleeker, 1877. t. a. p. (p. 156 noot 1). Bibliographie. 
".Atlas ichthyologique des Indes" samen te stellen, een groot plaatwerk met beschrijvingen van de Indische vischsoorten, en in I 845 wendde hij zich om steun tot de Indische Regeering: hij vroeg de beschikking over een teekenaar en de toestemming arak uit 's Rijks magazijn te mogen betrekken en bood daarentegen aan zijn geheele verzameling belangeloos aan het Leidsche museum af te staan, en tevens al zijn ichthyologische geschriften en platen aan het Gouvernement ter publicatie aan te bieden. $\mathrm{Na}$ herhaald aandringen wordt hem.... een gratificatie van $f 500$ toegekend, nog wel in twee termijnen te betalen. Een dergelijk antwoord is voor een wetenschappelijk onderzoeker een beleediging.

Toen nu BleEkER in i 850 het verzoek van TeMminck kreeg, voor het Leidsche museum te willen verzamelen, was het voor hem eenigszins moeilijk, hieraan te voldoen. Dank zij echter de meer verlichte geest van de Regeering en van den nieuwen Gouverneur-Generaal Devmaer r. Twist, werd hem nu alle steun verleend en kon hij groote verzamelingen naar Leiden zenden. Zijn "Atlas ichthyologique" heeft hij niet voltooid gezien.

Van de particulieren, die na Bleeker dergelijk dierkundig werk verrichtten, is in de eerste plaats te vermelden Dr. A. G. Vorderman, wien het Natuurk. Tijdschr. tot 1902, het jaar van zijn overlijden, belangrijke ornithologische bijdragen dankt, de vrucht van het werk op zijn reizen als Inspecteur van den Burgerlijken Geneeskundigen Dienst; verder Dr. O. Moнnike en Dr. B. Hagen, twee Duitsche geneesheeren, die beiden Indische natuurstudie als lief hebberij hadden, en van wie vooral de laatste aan het Leidsche Museum en de door dit Museum uitgegeven „.Notes" belangrijke bijdragen uit Deli zond; voorts de vlinderverzamelaar Mr. M. C. PIEPERs, de zoogdieronderzoeker Dr. J. H. F. Kohlbrugge en de beoefenaar der algemeene faunistiek, vooral van Krakatau en Simaloer, Edward JACOBSON. 
De Natuurkundige Vereeniging had een Museum gesticht, een vooral in de tropen eenigszins gevaarlijk waagstuk. Maar door de goede zorgen van Dr. C. P. Suuter, die toen naast een leeraarswerkkring aan de H. B. S. te Batavia, ook het conservatorschap van dit Museum waarnam, was het omstreeks I 885 een bloeiende van een Aquarium voorziene instelling, waar vooral van de zeefauna, die Dr. Sluiter's bijzondere voorliefde had, een belangrijke verzameling aanwezig was. Zijn pogen om behalve het Museum ook een zoölogisch station in Tandjong Priok te stichten, mislukte helaas door finantieele bezwaren. Maar al spoedig zou de bloeitijd van dit museum voorbij zijn: Dr. Sluiter vertrok in i89i als lector naar Amsterdam, waar hij thans hoogleeraar is; zijn opvolger, Dr. J. F. van Bemmelen bleef slechts korten tijd, en in I90 I waren museum en aquarium door de afwezigheid van een vakzoöloog te Batavia, vervallen. Hoe intusschen in 's Lands Plantentuin, op TrEub's initiatief, ook zoölogisch onderzoek was ter hand genomen, een zoölogisch museum en later een visscherij-laboratorium gesticht werden, terwijl tegenwoordig ook aan de proefstations practisch-zoölogische studies gemaakt worden, zullen we later zien.

Het probleem der Indische Zoölogie bij uitnemendheid, het vraagstuk, voor welks oplossing alle zoölogische onderzoekingstochten waren ondernomen, was de aardrijkskundige verspreiding der diersoorten in onzen Archipel, de zoögeographie.

Een opvallend verschil in fauna tusschen het westelijk en oostelijk deel van den Indischen Archipel, het eerst duidelijk aangetoond door Salomon Müller ${ }^{\mathrm{I}}$ ), die ons in zijn groot werk over de zoogdierfauna van den Indischen Archipel opmerkzaam maakte op het feit, dat Celebes en Timor het oostelijke grensgebied van de echte Indische fauna vormden, en

ז) Zie hierboven. p. I21. 
DE STUDIE DER DIERENWERELD NA I 850 .

tegelijk de meest westelijke verspreidingsstreken van Australische dieren ${ }^{\mathrm{I}}$ ), werd door dezen onderzoeker later nader onderzocht en als studieonderwerp voor een historisch zeer belangrijke verhandeling ${ }^{2}$ ) gekozen. Daarin vinden we een uitspraak, die voor tallooze latere zoögeographische geschriften een punt van uitgang geweest is: ,Der indische Archipel zerfällt demnach in geographisch-naturhistorischer Hinsicht, der Länge nach in zwei Hälften von ungleicher räumlicher Ausdehnung. Die westliche grössere Hälfte umfasst die Inseln Borneo, Sumbawa, Java, Sumatra und die Halbinsel Malakka; die östliche Hälfte nur Inseln des zweiten und dritten Ranges, nämlich Celebes, Flores, Timor, Gilolo und etwa Mindanao in der äusseren Umgrenzung" 3). Daaruit is afgeleid, wat later als , lijn van MüLlER" bekend zou worden: een scheidingslijn dwars door onzen Archipel, beginnend ten N. van Mindanao, door de Soeloe-eilanden en den straat van Makassar naar het Zuiden en dan tusschen Soembawa en Flores door. De oorzaken, die Salomon Müller voor de verklaring van dit verschijnsel meende te kunnen opgeven, zijn weliswaar vermoedelijk onjuist, maar volkomen begrijpelijk, indien we bedenken, dat in zijn tijd geheel andere opvattingen omtrent het ontstaan van dierenen plantensoorten gehuldigd werden, dan thans. Hij zegt: „Da die östlichen Inseln durchgängig kleiner von Umfang, niedriger in ihrer Bodenerhebung, im allgemeinen unfruchtbarer, daher selten mit grossen Waldungen prangend, und dabei viel unregelmässiger in ihren klimatischen Verhältnissen sind, als

3) Salomon Mëller, 1839. Over de Zoogdieren van den Indischen Archipel. (Verhand. o. d. natuurl. gesch. der Nederl. Overz. Bezittingen. I839-rS44. Zoölogie. I e stuk. p. I-57). p. 9.

2) Salomon MÜllek, i846. Ueber den Charakter der Thierwelt auf den Inseln des Indischen Archipel. (Archiv. f. Naturgeschichte, XII. p. Io9-128).

3) Salomon Müller, I846, t. a. p. p. Iog. 
DE STUDIE DER DIERENIERELD NA I850.

die mit den grössten europäischen Königreichen in Ausdehnung wetteifernden westlichen, ist auf ersteren auch die Zahl der hauptsächlich von vegetabilischer Nahrung lebenden Thiere verhältnissmässig nur gering" ${ }^{x}$ ).

Geheel andere oorzaken, dan de door MüLLER aangenomen physiologische factoren, werden door W. EARLE ${ }^{2}$ ) voor de verklaring der dierenverspreiding aangegeven: de geologische structuur der Indische eilanden, waaraan volgens hem Borneo, Sumatra en Java met Zuidoost-Azië door een groote bank verbonden waren, die misschien zelfs tot de Zuidwestelijke punt van Celebes reikte, terwijl aan den anderen kant Australië met Nieuw-Guinea en de Aroe-eilanden door een bank vereenigd waren. Het daartusschen liggende gebied zou dan door vulkanische uitbarstingen de merkwaardig-grillige vormen gekregen hebben. EArLE's groote verdienste ligt dus voornamelijk hierin dat hij de eerste was, die de beteekenis van geologische factoren voor de verspreiding der diersoorten over de aarde, begreep.

Van MüLler's lijn werd gebruik gemaakt door Sclater $\left.(1858)^{3}\right)$, die op grond van de verspreiding der vogels trachtte de geheele aarde in zes ,regiones" te verdeelen; de lijn van MüLLer vormde in zijn stelsel de grens tusschen het Indisch of Orientaalsch gebied, waartoe het westelijk gedeelte van den Archipel dus behoorde, en het Australische gebied, waartoe het oostelijk deel gerekend worden moest. SCLATER toont zich eenigszins sceptisch ten opzichte van de zuiverheid dezer grens: vooral de fauna van Celebes geeft hem groote moeilijkheden. De in zijn tijd heerschende star-dogmatische opvattingen hadden

I) SALOMON MÜLLER, I846. t. a. p. p. III.

2) IV. EARLE, I 845 . On the physical structure and arrangement of the islands of the Indian Archipelago. (Journ. Roy. Geogr. Soc. I.ondon, XV. p. $358-365$ ).

3) P. L. Sciater, IS58. On the general geographical distribution of the members of the class Aves. (Journ. Linn. Soc. Zoül. II. p. 130-145). 
DE STUDIE DER DIERENIERELD NA I 850.

natuurlijk tengevolge, dat SClater tot deze, voor ons eigenaardige conclusie kwam ${ }^{x}$ ): „But I suppose few philosophical zoologists, who have paid attention to the general laws of the distribution of organic life, would now-a-days deny that, as a general rule, every species of animal must have been created within and over the geographic area, which it now occupies". De nieuwere meeningen over het ontstaan van soorten, die na 1859 begonnen veld te winnen en waarvan A. R. WALLAcE zelf een der voorvechters was, deden de geologische theorie van EARLE meer tot haar recht komen, zoodat WALLACE dan ook veel scherper dan door EARLE geschied was, geologische factoren voor de verspreiding der soorten aansprakelijk stelde. $\mathrm{Na}$ zijn voorloopige verhandeling uit het jaar $1859^{2}$ ), werkte hij zijn theorie voornamelijk uit in zijn "Malay Archipelago" $\left.(\text { I } 864)^{3}\right)$. Daaruit is voortgekomen, wat gedurende langen tijd in de zoölogische litteratuur als ,lijn van WALIACE" zou bekend zijn, een scheidingslijn, die met de lijn van MüLler in zooverre overeenstemt, dat ze Borneo en Celebes scheidt, maar in het Noorden en Zuiden aanmerkelijk verschilt: waar de lijn van Müller liep ten Noorden van Mindanao, ligt de lijn van Wallace tusschen Mindanao en de Sangi- en Talaut-eilanden, terwijl in het Zuiden Müller de scheiding nam tusschen Soembawa en Flores, WaLlace echter tusschen Bali en Lombok. De dierenwereld van deze beide eilanden zou dan meer verschil vertoonen, dan die van Japan en Engeland. Voortbouwend op EARLE'S meening, nam WALLACE ter verklaring aan de vroegere aanwezigheid van een landverbinding tusschen het Indische

x) P. L. Sclater, 1858. t. a. p. p. 131 .

2) A. R. WAllace, 1859. On the zoological Geography of the Malay Archipelago. (Journ. Linn. Soc. Zoöl. IV. p. I72-184).

3) A. R. WAllace, 1864. t. a. p. 
vasteland en de westelijke Archipelhelft, terwijl het oostelijk gedeelte met Australië één groot continent gevormd zou hebben. Verspreiding door zeestroomingen zou de afwijkingen veroorzaakt hebben; mogelijk waren ook de uitzonderingsgevallen relicten van een nog oudere fauna, die ten tijde van een landverbinding tusschen Australië en Azië geleefd had. Ook Wallace gevoelde de grootste moeilijkheden in de fauna van Celebes; van zijn oorspronkelijke meening, dat Celebes tot het Australische Continent zou behoord hebben, is hij nooit geheel teruggekomen, al meent hij wel later dit merkwaardige eiland als een abnormaal eiland te kunnen karakteriseeren ${ }^{x}$ ). Zooals echter vanzelf spreekt, is WALLACE's meening gedurende de meer dan dertig jaren, die hij aan de Zoögeographie van Nederlandsch-Indië werkte, vaak veranderd, telkens rekening houdend met nieuw ontdekte feiten. Een overzicht hiervan vinden we in het schitterend werk van $\mathrm{P}$. en F. SARASIN ${ }^{2}$ ), die de gedachtenontwikkeling van WALLACE zeer kenmerkend als volgt samenvatten: ,Man kann somit sagen, dass sich durch die sämmtlichen, späteren WaLLACE'schen Schriften zwei sich widersprechende Gedankengänge hindurchziehen, einmal das Suchen nach einer wirklichen Grenze einer australischen und einer orientalischen Region und das Festhalten an seiner Linie als einer solchen, anderseits die Erkenntniss, dass Celebes in keine der beiden Regionen eingereiht werden kann oder mit anderen Worten, dass die Regionen keine Grenzen haben" "). Deze laatste opvatting, die bij WaLlace slechts zoo nu en

I) A. R. WALlaCe, IS76. The geographical distribution of animals. (I.ondon, 1876). vol. II. p. 177 .

2) P. und F. Sarasin, Igor. Naterialiën zur Naturgeschichte der Insel Celebes III. Ueber die geologische Geschichte der Insel Celebes auf Grund der Thierverbreitung. (Wiesbaden, 190r).

3) P. und F. SARASIN, I901. t. a. p. p. 148 . 
DE STUDIE DER DIERENIVERELD NA I850.

dan om den hoek komt kijken, is reeds vroeg verdedigd door Ed. von Martexs ${ }^{1}$ ), die in 1867 tot de conclusie kwam: ,So möchte ich denn hier so wenig wie anderwärts eine bestimmte Grenze ziehen, sondern nur im allgemeinen eine westliche und eine östliche Hälfte, und einen allmählichen Uebergang einer Fauna in die andere annehmen" $\left.{ }^{2}\right)$. Bijzonder scherp definieert Von Martexs dan zijn standpunt in 1889: „Fast jede Thiergattung ergiebt wieder eine andere Grenze, eine scharfe Gesammtgrenze existiert in der Natur auch hier nicht" ${ }^{3}$ ).

Bij deze beschouwingen van Vox Martens, die zijn meening vooral op de bestudeering van land- en zoetwatermollusken baseert, sluit zich in I894 MAx WEBER ${ }^{4}$ ) aan, die in de bewerking van de door hemzelf bijeengebrachte verzameling van zoetwatervisschen gelegenheid vindt, uitvoerige zoögeographische beschouwingen te geven. Ook hij komt sterk op tegen het schematische karakter van de ,lijn van WALLACE”; een algemeen geldende grenslijn is niet te trekken; ieder genus, ja eigenlijk iedere soort heeft zijn eigen grenslijn, zoodat we tusschen beide oorspronkelijke regiones een uitgestrekt overgangs- of menggebied vinden.

Een uiteenzetting van de bereikte resultaten op zoögeographisch gebied naast deze algemeene beschouwingen, zou wegens de buitengewone ingewikkeldheid van het probleem te oppervlakkig worden; men zou kunnen zeggen: ieder eiland, vooral in het overgangsgebied, heeft zijn eigen fauna (opvallend

1) Ed. ron Martens, I867. Die Preussische Expedition nach Ost-Asien, Zoolog. Theil. Band II. Landschnecken. (Berlin, 1867).

2) Ed. von Martens, 1867. t. a. p. p. 422 .

3) ED. vox Martens. Banda, I889. Timor und Flores. Tagebuchnotize. (Ztschr. Ges. f. Erdkunde. Berlin, XXIV, I889. p. 83-I3I). p. I04.

4) Max Weber, I894. Die Süsswasser-Fische des Indischen Archipels, nebst Bemerkungen über den Ursprung der Fauna von Celebes. (Zoölog. Ergebnisse. III. I894. p. $405-476$, vooral p. $459-476$ ). 
is bijv. het principieele verschil in zoetwatervischfauna tusschen de zoo dicht bij elkaar gelegen eilanden Aroe- en Hoog Kei, zooals MAX WEBER aantoonde), iedere diersoort haar eigen verspreidingsgrens, en zoo zou het een onuitvoerbaar voornemen zijn, daarvan in de beperkte ruimte van dit geschiedkundig overzicht een résumé te geven. Verwijzen wij daarom naar de historisch-kritische samenvattingen van Niermeyer $\left(1897^{\mathrm{I}}\right)$, Meyer en Wigglesworth i $898^{\circ}$ ), P. en F. Sarasin (igol ${ }^{3}$ ), G. Breddin (ig01 4), Max Weber (1902 ${ }^{5}$ ), Vax Kaypen (1909 ${ }^{\circ}$ ) en De Bealfort (I9I I ${ }^{7}$ ) en naar de belangrijke in den jongsten tijd verschenen verhandelingen van MAX WEBER over Nieuw-Guinea ${ }^{8}$ ), van VA.v Kaypen over Nieuw-Guinea ${ }^{9}$ ), van Max Weber over de Aroe- en Kei-eilanden ${ }^{\circ}$ ), van Max Weber en De Bealfort over Timor en Babber ${ }^{11}$ ), van De Bealfort over

I) J. F. Niermeyer, IS97. De geschiedenis van de lijn van WALlaCe. (Tijdschr. Kon. Ned. Aardr. Gen. $2^{\mathrm{e}}$ serie XIV. p. $75^{8}-765$ ).

2) A. B. Meyer and L. IV. Wigglesworth, I89S. The Birds of Celebes and the Neighbouring islands. 2 vols. (Berlin, 1898 ).

3) P. und F. SARAsin, I9Or. t. a. p. p. I4I-I62.

4) G. Breddin, 190r. Die Hemipteren von Celebes. Ein Beitrag zur Faunistik der Insel. (Abhandl. naturf. Gesellsch. Halle, XXIV, I90r. p. I-2I3). p. r35-I9I.

5) Max Weber, 1902. Der Indo-Australische Archipel und die Geschichte seiner Tierwelt. (Jena, 19c2).

6) P. N. yan Kampen, 1909. De Zoögeografie van den Indischen Archipel. Bijbl. Nat. Tijdschr. Ned.-Indië, rgog. 3 p. 8-i9 en 4 p. Io-2r ).

7) I. F. JEE BEAUfort, I9Ir. De zoögeographie van het oostelijk deei van den Indo-Australischen Archipel. (Hand. XIII Ned. Nat. Gen. Congr. I9Ir. p. 242-24S).

8) Max Weber 1908 Süsswasserfische von Neu-Guinea. Ein Beitrag zur Frage nach dem früheren Zusammenhang von Neu-Guinea und Australië. (Nova Guinea, V, r908. p. 20I-267). p. 20I-225.

9) P. N. yan Kampex; 1909-1913. Amphibiën. (Nova Guinea, IX. p. $3 \mathrm{I}-4$ ) en p. $453-465$ ).

10) Max Weeer, rgr. Die Fische der Aru- und Kei-Inseln. Ein Beitrag zur Zoogeographie dieser Inseln. (Abh. Senck. Naturf. Ges., XXXIV. p. I-49). p. r-20,

ri) MAX WEBer and L. F. DE Beatfort, I912. On the freshwater fishes of Timor and Babber. (Proc. K. A. IV. Amsterdam. June 19r2. p. 235-240). 
Waigeoe in verband met andere Molukken ${ }^{\mathrm{I}}$ ), van MAx Weber over Celebes ${ }^{2}$ ) en de daar aangegeven meer speciale litteratuur.

Dank zij de nauwkeurige systematische bestudeering van alle diergroepen, en wel vooral van de zoetwaterfauna (Amphibiën, Visschen en Mollusken) is het nu mogelijk, zich ongeveer een beeld te vormen van het ontstaan der Indische dierenwereld; van hoe groote beteekenis voor onze kennis der geschiedenis van den Archipel deze studies op zoögeographisch gebied zijn, zal uit het bovenstaande duidelijk zijn. Maar tevens moeten wij erop wijzen, hoe groote en hoe moeilijke problemen hier nog op een oplossing wachten, en hoe ook het nauwkeurig onderzoek der verschillende eilandenfauna's een zaak van dringenden aard is. Wij zijn op den goeden weg; een toekomstig geschiedschrijver moge naast de beantwoording dezer belangrijke vraagstukken kunnen vermelden, dat Nederland de voornaamste onderzoekingen over de zoögeographie van zijn Archipel verricht heeft.

I) L. F. DE BEAUfort, I9r3. Fishes of the eastern part of the Indo-Australian Archipelago with remarks on its Zoogeography. (Bijdragen Dierkunde. Artis, XIX. p. $93-164)$. p. I53-I64.

2) Max Weber, 1913. Neue Beiträge zur Kenntnis der Süsswasserfische von Celebes. (Bijdragen Dierkunde. Artis, XIX. p. 105-213). p. 195-201. 


\section{HOOFDSTUK IX.}

\section{Scheikundige arbeid na 1850.}

„Practische scheikunde is langs verschillende wegen naar Java gekomen, niet als weeldevak, doch overeenkomstig de behoeften van het leven, bepaaldelijk in het belang der cultures". In deze woorden van GreshofF ${ }^{\mathrm{I}}$ ) ligt opgesloten, dat vrijwel alle scheikundig onderzoek, in Indië verricht, betrekking heeft op de practijk: phytochemie en agricultuurchemie nemen de voornaamste plaats in; theoretische vraagstukken, als bijv. de rol van cyaanwaterstof bij eiwitvorming in planten, zijn van groot belang, maar worden vaak door practische onderzoekingen op den achtergrond gedrongen.

Omstreeks I 850 waren het de beide scheikundigen P. J. Maier en P.F. H. FromberG, door wier werk het chemisch onderzoek in Indië voornamelijk verricht werd. MAIER heeft zich in het bijzonder groote verdiensten verworven ten opzichte van het scheikundig onderzoek der op Java zoo talrijke heete bronnen en geneeskrachtige wateren, een nog te veel verwaarloosde richting van studie, waaraan later o. a. ook J. J. Altheer ( \pm I 860),

I) M. Greshoff, 1906. Scheikundige arbeid in Nederlandsch-Indië. (Indische Gids. XXVIII, I906. II. p. 1489-1495). p. 1490. 


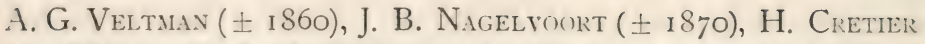
$( \pm 1880)$ en P. A. A. F. EIJkEx ( \pm I 895$)$ meegewerkt hebben. Juist in den tegenwoordigen tijd, nu vooral radioactieve bronwateren hoe langer hoe meer gewaardeerd worden, en jodiumhoudende bronnen voor jodiumwinning sterk in beteekenis toenemen, wordt het nauwkeurig scheikundig onderzoek van deze minerale wateren van steeds toenemend belang.

Het was G. J. Mulder's invloed, die de regeering ertoe bracht, in I $848 \mathrm{P}$. F. H. FromberG ${ }^{1}$ ) naar Indië te zenden, ten einde daar landbouwscheikundige onderzoekingen te doen. En nadat Fromberg een drietal jaren over Java gereisd had, stichtte hij (185I) te Buitenzorg een agricultuurchemisch laboratorium, waar zijn voornaamste scheikundige geschriften de chemie ran het suikerriet behandelden; daarnaast verschenen van zijn hand ook enkele mededeelingen over cassavewortel, muscaatnootschillen, koffiecultuur, guano als meststof, gesteentenanalyse enz. Het laboratorium-onderzoek nam geen vlucht, wel was K. IV. rA. GoRkon nog eenigen tijd assistent, maar toch werd het eerste scheikundige laboratorium nog geen tien jaar na zijn oprichting, in I860, opgeheven. De directeur Fromberg was in $185^{8}$ gestorven. Mulder achtte de zaak belangrijk genoeg om door te zetten; in 1850 was reeds een scheikundig laboratorium van den geneeskundigen dienst opgericht, waar dan militairapothekers gelegenheid konden vinden voor wetenschappelijk onderzoek. Maar toch: „De scheikundige wetenschap heeft daar echter niet zooveel van geprofiteerd, als de Utrechtsche hoogleeraar (G. J. MuLder), die zelf nooit militair geweest was, wel verwachtte: de hospitaal-practijk bleek met beoefening der chemie moeilijk vereenigbaar, en een militair régime is niet gunstig voor wetenschappelijk onderzoek. Niettemin zij met

2) Zie p. 134 . 
eere vermeld, dat er toch uit Indische militaire apotheken niet zelden chemische bijdragen zijn gekomen" ").

Belangrijke resultaten dankt de scheikunde aan de hopelooze verwarring en strijd, die in Jungitms's tijd over de kina-cultuur heerschte. Junghunn begreep, dat de scheikundige kennis van de kina van het grootste belang was, en het kostte hem weinig moeite, den Gouverneur-Generaal PaILd, die reeds als Minister van Koloniën HassKarL's zending naar Zuid-Amerika bewerkt had, te bewegen een scheikundige aan te stellen, speciaal voor het onderzoek der verschillende kinabastsoorten. G. J. Mulder, meestal in scheikundige zaken regeeringsadviseur, beval daarvoor sterk aan den nog jongen, maar zeer begaafden K. W. YA.: Gorkon, militair-apotheker. Maar IUnghumin en PAHUd wilden een ander: den leeraar aan de Rotterdamsche klinische school J. E. DE VRIJ, die reeds vroeger zich met kina-onderzoek had beziggehouden. DE VRIJ werd benoemd, ondanks Mulder's tegenwerking.

Jonan ElizA DE $\mathrm{VRIJ}^{2}$ ) was reeds op i9-jarigen leeftijd (hij was geboren 3 I Januari I $_{\text {I }_{3}}$ ) genoodzaakt de Rotterdamsche apotheek zijns vaders, na diens overlijden zelfstandig te drijven. Grondig onderlegd door de lessen van G. J. Mulder, die in dien tijd leeraar aan de klinische school was, ging hij in $18_{35}$ naar de Leidsche universiteit over, terwijl hij nog steeds het beheer der apotheek voerde. Den $25^{\text {sten }}$ Juni i $8_{3} S$ promoveerde hij daar tot Magister Matheseos et Doctor philosophiae naturalis op een physiologisch-chemische dissertatie. Bij MuLder's vertrek naar de Utrechtsche hoogeschool bleek reeds, hoe de verhouding tusschen beide mannen geworden was: DE VRIJ had voor zijn

^) M. GRESHOFF, 1906. t. a. p. p. 1490.

2) F. A. Flüchiger, i893. Dr. Johan Eliza de VRY. (In: Gallerie hervorragender Therapeutiker und Pharmakognosten, herausbegeben von B. REBER. Genf, 1892. Sonderabdruck 18 pp.). 
SCHEIKUNDIGE ARBEID NA I 850 .

leermeester grooten eerbied, maar was volstrekt niet geneigd, iedere meening van Mulder als een evangelie te beschouwen; Mulder beval dan ook niet De VriJ, maar een medicus als zijn opvolger aan; toch werd DE VRIJ benoemd (I $S_{4} I$ ). Zestien jaar lang bleef DE VRIJ in dit ambt werkzaam; kreeg intusschen ook in het buitenland groote bekendheid door zijn talrijke chemische publicaties van den meest uiteenloopenden aard, begon na de wereldtentoonstelling te Parijs in 1855 met kinastudiën, en maakte daar kennis met de meest bekende kinaonderzoekers, o. a. Weddell. Toen nu Junghuin in 1856 de kinacultuur van HassKarl overgenomen had, leek DE VRIJ wel de aangewezen man, om hem daarbij op chemisch gebied ter zijde te staan.

In den zomer van I 857 volgde DE VRIJ zijn bestemming en kwam 8 Januari 1858 te Batavia aan. De vijf jaar, die DE VRIJ in Indië, grootendeels in Bandoeng, bleef, besteedde hij voornamelijk aan het chemisch onderzoek van kinaschors, o. a. aan het bereiden van kinine-oxalaat. $\mathrm{Na}$ afloop van deze periode moest DE VRIJ om gezondheidsredenen Indië verlaten, waarbij zijn kinologische studiën echter nog geen einde vonden. Tot zijn dood toe heeft hij over dit belangwekkend onderwerp gearbeid en geschreven. Ongeveer zeventig „Kinologische Studiën" zagen het licht, en daarnaast publiceerde hij nog de resultaten van ander, in Indie uitgevoerd chemisch werk: over de suiker uit de suikerpalm, Arenga Saccharifera; over glycosiden in Citrus-bloesems, enz. DE VRIJ verliet Indië met verlof, maar verkreeg na afloop van dit verlof op zijn verzoek ontslag, zoodat Junghums thans weer alleen de kina-cultuur te leiden had. En na Junghuns's dood (1864) was de kinacultuur geheel zonder leiding; teeltkundige en vooral scheikundige fundamenteele vragen wachtten op beantwoording, en thans werden de zware verantwoordelijkheid voor het welslagen van deze cultuur, 



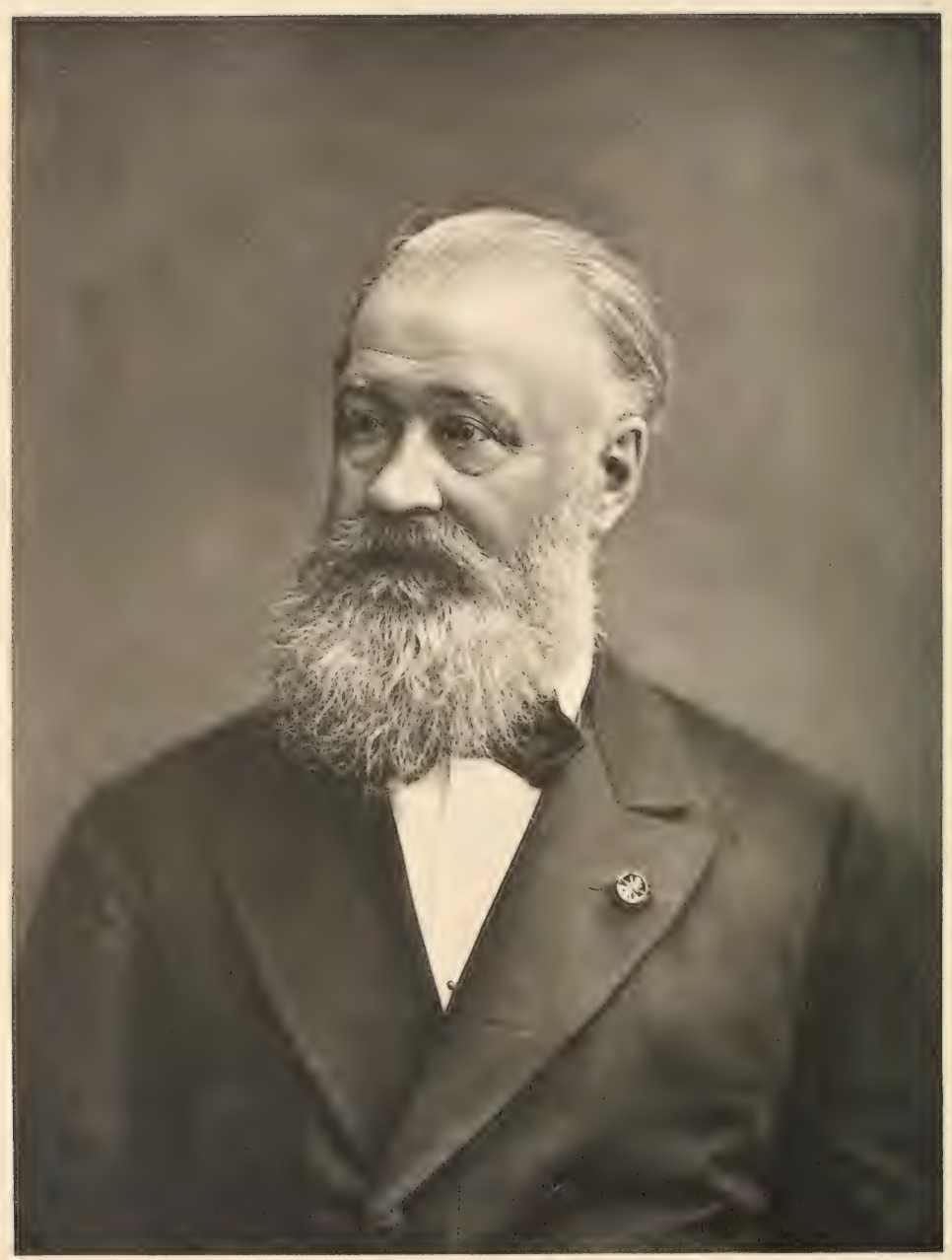

J. E. DE VRIJ. 
waarvan groote belangen der menschheid afhankelijk zijn, op de schouders gelegd van den 2 S-jarigen K. W. vas Gorkos, den jongen militair apotheker, die reeds negen jaar te voren door Mulder voor scheikundige aanbevolen was. Nu kon het blijken, dat Mulder zich in VAN GORKOMI niet vergist had.

Karel Wessel van Gorkoni ${ }^{\mathrm{I}}$ ), geboren 22 Augustus $18_{35}$ te Zutphen, studeerde onder Mulder, later ook bij de Vriese en Blume. en vertrok in 1855 als militair-apotheker naar Indië, waar de door Mulder voor hem bestemde plaats aan DE VRIJ toegewezen was. $\mathrm{Na}$ een korten werktijd aan het militair hospitaal te Weltevreden, werd VAN Gorkom aan het landbouwscheikundig laboratorium geplaatst, dat echter spoedig na FromberG's dood opgeheven werd. Van hier ging hij als controleur naar Rembang, werd in $186_{3}$ benoemd tot secretaris der enquête-commissie voor de Gouvernements-koffiecultuur en kreeg het volgend jaar, nog voor JunGHuHn's overlijden, het aanbod de inspectie der kinacultuur op zich te willen nemen. De felle bestrijding, die JunghuHn's methoden gevonden hadden, makkte zijn taak niet licht; toch aarzelde hij niet zich beschikbaar te stellen. En van het oogenblik af, dat VAN Gorkom de leiding aanvaardde, gaf de kina geen stof meer voor zoo talrijke strijdschriften van bevoegden en onbevoegden.

Onder meewerking van enkele gunstige omstandigheden (in dezen tijd werd het zaad van Cinchona Ledgeriana, de beste van alle kinasoorten, ingevoerd), wist VAN Gorkom de kinacultuur tot groote hoogte op te voeren. Ieder jaar gaf hij verslag van den stand der aanplantingen in het Nat. Tijdschrift. Als scheikundige stond VAN Gorkom lang niet gelijk met DE VRIj of met Moens, zijn kracht lag in zijn juisten blik op

I) P. v. D. Wielen, igio. Dr. Karel Wessel van Gorkom. (Eigen Haard. $36^{\mathrm{e}}$ Jaargang. I910. p. 184-186). 
SCHEIKUNDIGE ARBEID NA I850.

landbouwtoestanden en vraagstukken betreffende de kinateelt. Tot I875 bleef VAx Gorkom voor de kina werkzaam; in dat jaar werd hij benoemd tot Hoofdinspecteur der suiker- en rijstcultuur, en droeg hij het bestuur der Gouvernementskina-onderneming over aan J. C. Bernelot Moens, voor wien de richting, waarin gewerkt moest worden, thans aangegeven was. VAN Gorkom keerde in I880 naar Europa terug, vestigde zich te Baarn, en bleef hier nog dertig jaar met groote toewijding werkzaam in het belang der Indische cultures. Reeds een jaar later verscheen zijn standaard-werk: ,Oost-Indische cultures in betrekking tot handel en nijverheid" ${ }^{x}$ ), getuige van een veelzijdigheid van kennis en een ruim inzicht, een werk, thans, na ruim dertig jaar, door een aantal speciale onderzoekers onder redactie van Dr. H. C. Prinsen Geerligs ${ }^{2}$ ) in een nieuw kleed gestoken. VAx Gorkon, sedert I 886 Dr. pharmaciae honoris causa aan de Universiteit te Utrecht, overleed Io Maart I9IO te Baarn.

$\mathrm{Nu}$ de kinacultuur geregeld was, en zich op den goeden weg bevond, was de taak voor VAN Gorkom's opvolger, Bernelot Moens, aanmerkelijk lichter. J. C. Bernelot Moens, geboren 4 Januari ${ }^{8} 87$ te Kralingen, werd 20 Juli 1857 als militairapotheker $3^{\mathrm{e}}$ klasse aangesteld, eerst voor West-Indië, daarna (3 Mei 1858 ) voor Oost-Indië. In November te Batavia aangekomen, werkte hij hier tot 1866 in het chemisch laboratorium van den geneeskundigen dienst vooral aan het analytisch onderzoek van mineralen en aardsoorten. Overgeplaatst naar het militair-hospitaal te Weltevreden, legde hij zich hier toe op drinkwateronderzoek en ook op scheikundige bestudeering van

r) K. W. VAN GORKOM, I880-188r. Oost Indische cultures in betrekking tot handel en nijverheid. (Amsterdam, 1880-8I en Supplement r890).

${ }^{2}$ Idem. $2^{\mathrm{e}}$ druk. 2 dln. Amsterdam, I884. Idem. Opnieuw uitgegeven onder leiding van Dr. H. C. Prinsen Geerligs. Amsterdam, igr3. 
kinabast. Dit was aanleiding, dat hij in 1872 eerst als scheikundige, daarna als adjunct-directeur der kina-cultuur aan VA. Gorkosr toegevoegd werd, en dezen in 1875 als directeur opvolgde. In $188_{3}$ verliet Moens Indië met verlof naar Europa, nam twee jaar later ontslag uit den dienst, en overleed 2 October I886 te Haarlem, nog geen vijftig jaar oud. Een aantal verspreide mededeelingen over scheikundig kina-onderzoek verschenen van zijn hand. Bernelot Moens zelf kenmerkte de beteekenis der scheikunde in zijn prachtige monographische arbeid: „De Kina-cultuur in Azië" ${ }^{\mathrm{I}}$ ) aldus: "Nooit wellicht is het nut der scheikunde bij een tak van landbouw zoo schitterend uitgekomen als bij de cultuur van kina". Werkelijk is er geen cultuuropkomst zoozeer af hankelijk geweest van den steun der scheikundige wetenschap, als deze eerste van regeeringswege met kracht aangevatte teeltproeven. Maar daartegenover heeft ook de scheikunde van deze cultuur veel voordeel genoten; de juiste kennis van de verschillende kina-bestanddeelen is vooral door het werk van DE VRIJ en Moens krachtig bevorderd.

Langzaam begon zoodoende de beteekenis van scheikundig werk in de tropen ook in regeeringskringen gewaardeerd te worden en werd de behoefte merkbaar aan een stelselmatige chemische bestudeering der Indische planten; de phytochemie had zich in Indië baangebroken. Ook door het werk van J. F. Eljkman ") tijdens zijn korte verblijf in Buitenzorg, werd de aandacht der Regeering op het belang van phytochemisch onderzoek gericht. En als uiting hiervan vinden wij in r $88 S$ de toevoeging van den militair-apotheker Dr. M. Greshoff aan 's Lands Plantentuin, met opdracht het onderzoek naar de waarde der inlandsche geneesmiddelen te organiseeren.

1) J. C. Bernelot Moens, 1SS2. De Kina-cultuur in Azië, IS54-rSS2. (Batavia, 1882). Voorrede.

2) Zie pag. 205 . 
Matrits Greshof ${ }^{\text {I)}}$ ), geboren il October i 862 te 's-Gravenhage, was van jongsaf met hart en ziel chemicus: reeds als jongen vinden wij hem in het ouderlijk huis bezig met allerlei scheikundige proeven. $\mathrm{Na}$ de driejarige H. B. S. te hebben doorloopen, waar hij de mooie lessen van Dr. L. Bleekrode genoot, werd hij apothekersleerling, deed examen voor apothekersbediende, en slaagde erin, een plaats te vinden bij de opleiding voor militair-apotheker voor Indischen dienst. Zoo kwam hij met Prof. Wefers Bettink in aanraking. Uit Greshoff's studententijd zijn reeds een paar artikelen in het „Pharmaceutisch Weekblad", het Album der Natuur en HaAxian's Tijdschrift voor Pharmacie. In 1885 werd hij tot apotheker bevorderd, en promoveerde ruim een jaar later ( 30 Augustus 1887 ) te Jena tot Doctor philosophiae. Kort daarna naar Indië vertrokken, werd hij hier aan het hospitaal te Weltevreden werkzaam gesteld, waar hij zich op hygienisch-chemische studiën toelegde. Het volgend jaar, na Treub's terugkeer, werd Greshoff bij Gouvernementsbesluit voor den tijd van een jaar aan den Directeur van 's Lands Plantentuin toegevoegd; in 1889 werd deze toevoeging met een jaar verlengd, totdat hij in 1890 voorgoed aan den tuin verbonden werd, al zou het slechts voor korten tijd zijn: in 1892 ging hij met ziekte-verlof naar Europa, bracht een tijd op Madeira door en werd spoedig na zijn aankomst in ons land als scheikundige aan het Koloniaal Museum verbonden. Hoewel het Museum oorspronkelijk geen chemisch laboratorium bezat, wist hij toch ook hier zijn onderzoekingen voort te zetten en zag in 1898 een naar zijn wenschen ingericht laboratorium voltooid worden. Inmiddels had hij (I896) voor een hem aangeboden hoogleeraarsambt bedankt en werd hem het onder-directeurschap van ,zijn" museum opgedragen.

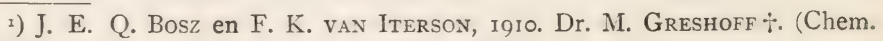
Weekbl. VII, 1910. p. 23I-249. m. bibliographie). 



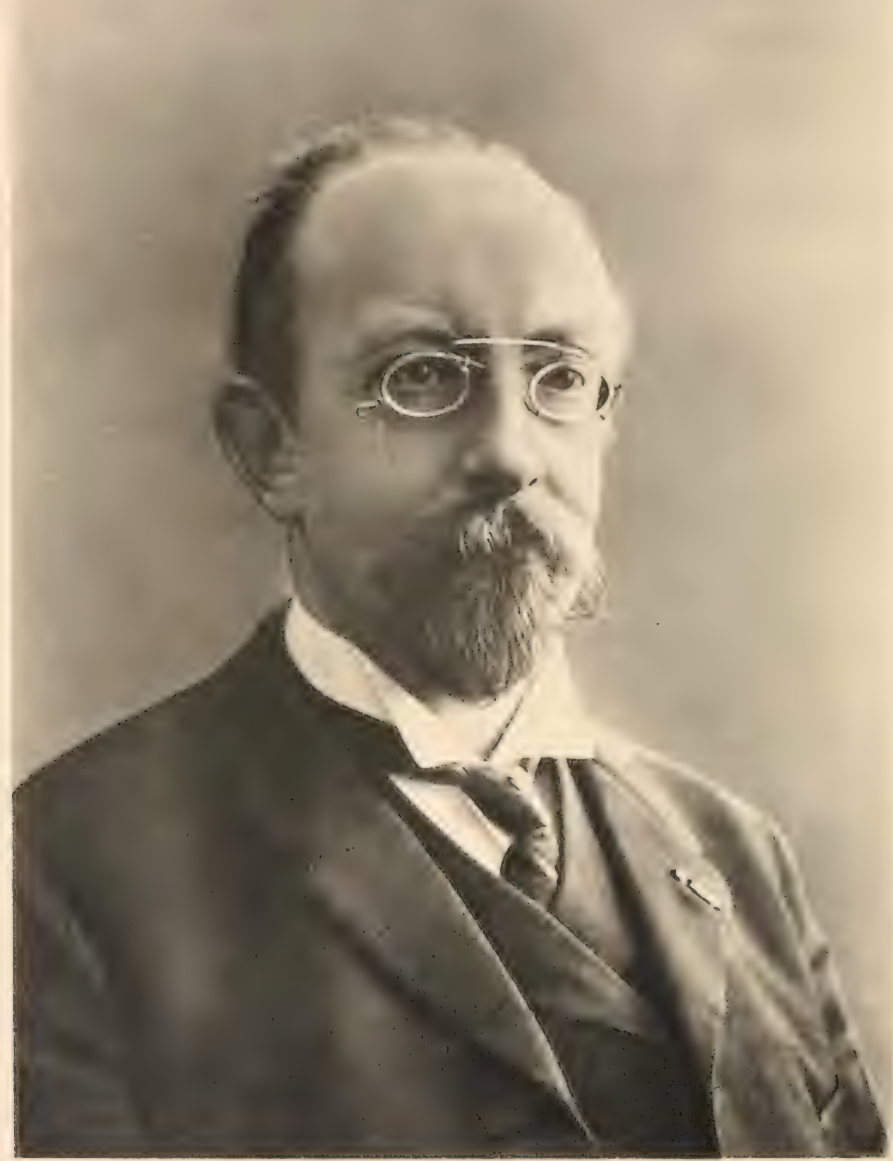

M. GRESHOFF. 
Na V.in Eeden's overlijden (I9OI) volgde Gresioff hem als directeur op, en bleef aan dezen werkkring zijn geheele arbeidskracht wijden, totdat 8 December 1909 zijn levenseinde kwam.

De aan Greshoff bij zijn detacheering aan 's Lands Plantentuin opgedragen taak omvatte, ,het instellen van een chemischpharmacologisch onderzoek naar de plantenstoffen van Nederlandsch-Indië, in het bijzonder met het oog op hare beteekenis voor de geneeskunde". En vooral waren het de alcaloiden, die zijn aandacht boeiden; reeds in het „Eerste verslag" " $)$, dat hij over zijn werkzaamheden te Buitenzorg uitbracht, kon hij de ontdekking melden en een beschrijving geven van zijn , lievelingsalkaloïd" carpaine, een bestanddeel van papaya-blaren. Ook de algemeene vergiftleer had zijn aandacht; als resultaat daarvan verscheen in 1893 het eerste gedeelte van zijn „Beschrijving der giftige en bedwelmende planten bij de vischvangst in gebruik", waarvan in I900 het tweede gedeelte en in I9I 3 het derde gedeelte volgde. Vooral dit laatste deel geeft veel meer dan de titel zegt; eigenlijk is het als een handboek voor phytochemie te beschouwen. Ook zijn Indische Vergiftrapporten (I, I 899; II I900; III I9I4) zijn een getuige voor GreshofF's algemeene phytochemische kennis; de warme beoordeelingen, die dit werk ten deel zijn gevallen, geven hiervoor het bewijs. En zijn ontdekking van cyaanwaterstof in de blaren van Pangium edule, die aanleiding gaf tot Treus's werk van buitengewone beteekenis voor het onderzoek naar eiwitvorming in planten, is reeds vroeger vermeld. Greshorf's groote verdienste ligt vooral in het systematische van zijn onderzoekingsmethode; door zijn stelselmatigen arbeid is hij de grondlegger geworden van de Indische phytochemie, de vergelijkende studie van de scheikundige samenstelling der tropische planten.

r) Zie voor de titels van Greshofr's verhandelingen de bibliographie bij Bosz en Van Iterson. 
SCHEIKUNDIGE ARBEID NA I $S_{50}$.

Slechts een viertal jaren heeft Gresnofy in Indië doorgebracht, maar deze jaren waren van beslissende beteekenis voor zijn verdere leven; GREshoff heeft Indie liefgekregen en heeft zijn gansche leven gewijd aan wat hij als zijn ideaal beschouwde: het Nederlandsche Volk te doordringen van het gevoel van verantwoordelijkheid jegens onzen Oost, het iets te doen gevoelen van wat in hem zelf leefde als warme belangstelling voor de natuur onzer tropen. Zoo is hij ook na zijn vertrek uit Indië werkzaam gebleven in het belang onzer koloniën, zoo is hij door zijn werkkring te Haarlem tot zegen geweest voor velen, die op zijn raad steunend, zich in Indie een positie hebben weten te verwerven. Maar naast den maatschappelijken kant van zijn nieuwe werk, bleef ook de wetenschap hem boeien; dat chemisch onderzoek van Indische planten in vele gevallen evengoed buiten de tropen kan geschieden, is ook weer door Greshoff's arbeid gebleken. Uit zijn talrijke onderzoekingen, in Europa verricht, noemen wij, behalve de scheikundige bestudeering van Indische voedingsmiddelen, die over alkaloiden in Composieten, over echinopsine, over cocaalkaloïden. Zijn regulatieven voor voedingsmiddelonderzoek (1903) en dat voor handelswaren (I909) hebben veel opgang gemaakt. Vragen van groot maatschappelijk belang waren het suiker- of saccharinevraagstuk, waarbij hij zich een groot voorstander van afschaffing van den suikeraccijns toonde, en de papiercontrôle, waarvoor hij krachtig streed, teneinde het toenemend gebruik van houtslijp bij papiervervaardiging tegen te gaan.

GRESHOFF was ongetwijfeld een onzer beste phytochemische onderzoekers en de grondlegger van de vergelijkende phytochemie in Ned.-Indië; niet een koude, nuchtere man van wetenschap, maar een persoonlijkheid, die in vuur kon raken voor wat hem na aan het hart lag: zijn strijd tegen de ,leugensuiker" saccharine, het populariseeren van natuurwetenschap, 
de studie van volksnamen voor planten, geschiedkundig onderzoek naar den ontwikkelingsgang der natuurstudie, dat alles vond in GRESHOFF een warm aanhanger en verdediger. Van een door hem gehouden voordracht: „Gedanken über Pflanzenkräfte und phytochemische Verwandtschaft" werd in de Süddeutsche Apothekerzeitung getuigd: „eine Arbeit, die erfiillt war von einer Fülle tiefer philosophischer Gedanken über ein Arbeitsgebiet, dessen einstiger Ausbau einst zu den ersten Errungenschaften des menschlichen Geistes zahlen wird". GreshorF leefde in zijn werk en zijn werk werd levend door hem. Wat van hem kwam, hetzij gesproken of geschreven, kon niet anders dan indruk maken; waar hij zich gaf, daar werd met vrucht gearbeid.

Nog een ander phytochemicus moet hier vermeld worden: P. C. Plugge, hoogleeraar in de pharmacie te Groningen. Pr.tGGE ${ }^{1}$ ), geboren 12 April 1847 te Middelburg, studeerde voor apotheker in Amsterdam en Groningen, promoveerde 29 September $1 \$ 76$ op een dissertatie: „Bijdragen tot de kennis der photochemie", en werd, na een korte werkzaamheid in Japan. benoemd tot hoogleeraar te Groningen, waar hij 24 Sept. IS 8 zijn intreerede hield. PLLGGE's belangrijke onderzoekingen betroffen voornamelijk Indische plantenstoffen; toen hij in $\mathrm{I}_{97} \mathrm{j}$ te Buitenzorg kwam om ook daar zijn phytochemisch werk tijdelijk voort te zetten, overleed hij eenige weken na zijn aankomst aldaar (29 Juni 1897).

Door de talrijke onderzoekingen van het Buitenzorgsche laboratorium voor pharmacologisch werk ²), dat sedert GREsirorF's vertrek (IS92) onder leiding staat van Dr. IV. G. Boorsura, is

2) D. Huizinga, iS95. P. C. Plugge. (In: Gallerie hervorragender Therapeutiker und Pharmakognosten der Gegenwart, herausgegeben von B. REeEr. Genf, 1895).

2) Publikaties in de uitgaven van 's Lands Plantentuin. 
SCHEIKUNDIGE ARBEID NA I 850 .

de phytochemie in Indië een vruchtdragende wetenschap geworden. In de eerste plaats waren het natuurlijk de cultuurplanten: thee, koffie, kina, tabak, rubber, die scheikundig onderzocht werden.

Landbouwscheikundig werk werd verricht in het agricultuurchemisch laboratorium ${ }^{\mathrm{I}}$ ), dat eerst door Dr. P. van Rombergh, na 1903 door Dr. W. R. Tromp de HaAs en Dr. A. W. K. DE JonG geleid werd. Thans vormt dit laboratorium een der technische afdeelingen van het Departement van Landbouw.

De praktische richtingen, waarin de scheikunde in Indië nog meer toepassing kon vinden, vatte GreshofF in 1906 aldus samen ${ }^{2}$ ): „Het toezicht op de zuiverheid en onvervalschtheid van levensmiddelen, een vak, waarin de scheikunde thans zoo groote diensten aan de maatschappij kan bewijzen, is in Indië nog niet terhand genomen. Ook de contrôle op geneesmiddelen en op geheimmiddelen en kwakzalverijen, waarin in de koloniën zeer levendige handel gedreven wordt, ontbreekt er geheel. Evenmin biedt de chemie daar de hand bij de waardebepaling van kunstmeststoffen, enz. Ook voor physiologisch- en toxicologisch-chemische onderzoekingen ligt op Java het veld nog nagenoeg geheel braak". Een deel van deze praktische onderzoekingen is echter sedert 1909 ter hand genomen door het Laboratorium voor Landbouw- en Handelsanalyses, gevestigd te Buitenzorg; het werk van meer wetenschappelijken aard wordt in het pharmacologisch laboratorium verricht.

Samenvattend zien wij dus de scheikunde in Indië als een vrijwel uitsluitend practische wetenschap: de bestudeering van bouwgrond en haar bemesting, contrôle en verbetering van de

$\left.{ }^{1}\right)$ Mededeelingen van het Agricultuur-Chemisch Laboratorium. Buitenzorg, I-.... (1912-heden).

$\Rightarrow$ M. GRESHOFF, 1906. t. a. p. p. 1494. 
bereiding van verschillende landbouwproducten (kina, suiker, thee, enz.), waardebepaling van het product, handelsonderzoekingen.

Maar ook blijven nieuwere stroomingen in de "theoretische" chemie niet zonder invloed op de onderzoekingen ten behoeve der practijk: naast bodem-analyse, zooals ze vroeger uitsluitend verricht werd, is de studie der kolloidale eigenschappen van den bouwgrond, waarover J. M. vaN BEMMELEN belangrijke bijdragen gepubliceerd heeft, van beteekenis geworden; de bepaling van bodemvruchtbaarheid wordt thans voor een deel langs kolloïdchemischen weg geleid. Trouwens de grootsche vooruitzichten, die de kolloïdchemie ons opent, vinden wij ook op ander gebied: de aanwezigheid van tairijke kolloiden in levende planten is oorzaak van de groote rol, die deze nog altijd min of meer geheimzinnige rubriek van scheikundige stoffen speelt, men denke bijv. aan de belangrijke functie der kolloïden bij de caoutchouc-fabricatie. Daarnaast is de studie der enzymen, eveneens een vrij sterk mystieke groep van stoffen, van vèrreikende strekking; ook het onderzoek der looistoffen, die bij de bereiding van landbouwprodukten een zoo gewichtige rol spelen.

Scheikundige arbeid valt in Indië dus nog veel te verrichten: door het onafhankelijk karakter der scheikunde, waardoor in vele gevallen landstreek en klimaat van ondergeschikt belang zijn, zal haar studie in Indië altijd in de eerste plaats practisch zijn.

Moge de voorspelling van Greshoff: ,Rijke vruchten voor chemie en physiologie, zoowel als voor het practische leven, zullen niet uitblijven", steeds meer bewaarheid worden! 


\section{HOOFDSTUK X.}

\section{Geologische ontdekkingen na $\mathbf{1 8 5 0}$.}

Geologie is in nog sterker mate dan zoölogie een vak van onderzoek, veel minder aan een vaste plaats gebonden en ook veel minder geschikt voor beoefening op een enkele plek in den uitgebreiden Archipel, dan de studie van plantenleven. Buitenzorg heeft wel zijn laboratorium voor geologische bodemstudie, waarvan de leiding in handen is van Dr. E. C. J. Monr, maar de hier verrichte arbeid is, evenals het aan het bacteriologisch laboratorium, waar Dr. E. DE KRUvFF de studie der bodembacteriologie leidde, uit den aard der zaak in het bijzonder op de practijk gericht. De beteekenis van de structuur en de samenstelling van den bodem voor de cultures is daar hoofdpunt van onderzoek, en zoo raakt het strengwetenschappelijk karakter dier geologische studies wel wat op den achtergrond. Geologie is een studierichting, die vooral door reizigers beoefend moet worden, en indien het bekende gezegde: ,als de berg niet naar Mohammed komt, dan moet Mohammed wel naar den berg komen", ooit juist is, dan is het dit in letterlijken zin voor geologen. Veldarbeid is voor geologen hoofdzaak, laboratoriumen studeerkamerarbeid bijzaak. 
Het systematisch onderzoek door het Mijnwezen, waaraan N. Wing Easton, R. Fennema, J. A. Hooze, C. J. van Schelle en R. D. M. Verbeek krachtig medewerkten en de reizen der Nederlandsche hoogleeraren K. Martix, G. A. F. Molengrafaf en A. Wichmann en der buitenlanders G. Boehi, A. Tobler, IV. Volz en J. Wanner schonken resultaten van zoo groote beteekenis, dat de gangbare meeningen omtrent de geologische geschiedenis onzer koloniën daardoor een ingrijpende verandering hebben ondergaan. Vooral de hoofdingenieur van het Mijnwezen R. D. M. VerbeEK, wiens Indische periode de jaren 1867-I90I, een vierendertigjarig tijdvak, omvat, heeft zich op dit gebied groote verdiensten verworven. VERBEEk's geschriften handelen over Borneo, Sumatra, Java, Banka, Billiton en de Molukken. In het bijzonder verdienen vermelding zijn uitvoerige onderzoekingen over de Oembiliën-kolenvelden, over Sumatra's Westkust (in samenwerking met de ingenieurs FEnNema en VAN Scherle), over Krakatau, over Java (samen met Fennema ${ }^{\mathrm{I}}$ ) en over de Molukken. Ook zijn omvangrijke litteratuuropgave van alle op Ned.-Indische geologie betrekking hebbende geschriften ${ }^{2}$ ) is een zeer nuttige arbeid voor allen, die zich met de geologische gesteldheid van onzen Oost-Indischen Archipel bezighouden.

De aan VERBEEK toegevoegde mijningenieurs ontwikkelden eveneens een groote werkzaamheid; vooral de mijningenieur Fennema, met wien Verbeer veel samenwerkte, en die in 1897 in het Posso-meer op Celebes op zoo droevige wijze het leven verloor ${ }^{3}$ ), heeft veel onderzoekingswerk verricht.

`) R. D. M. Vereeek en R. Fennema, 1896. De geologische bouw van Java en Madoera. 2 dln. (Amsterdam, I896).

a) R. D. M. VERBEEK, 1912-rgr4. Opgave van geschriften over geologie en mijnbouw van Ned. Oost-Indië. (Verh. geol. mijnb. Gen. v. Ned. en Kol. Geol. Serie I, (I9I2). p. $3 I^{1}-248$ en $I^{e}$ vervolg. Ibid. I, (19I4). p. 294-3I8).

3) R. D. M. Verbeek, I903. Levensbericht van Reinder Franema. (Jaarb. v. h. Mijnw. 1903. p. 123-147). 
En als palaeontologisch werk, door een niet-vakman verricht, maar met resultaten van bijzonder verre strekking, moeten de onderzoekingen van den toenmaligen officier van gezondheid Dr. E. Dubors, thans hoogleeraar te Amsterdam, vermeld worden. Zijn ontdekking te Trinil op Java van skeletgedeelten van Pithecanthropus erectus DuBoIS ${ }^{\mathrm{I}}$, een overgangsvorm tusschen aap en mensch, is ongetwijfeld van de grootste beteekenis, hoe ook de beslissing omtrent den ouderdom der lagen, waarin deze fossiele resten werden gevonden, namelijk of deze al dan niet tot het tertiaire tijdvak te rekenen zijn, moge uitvallen.

In Junghuns's tijd, en zelfs nog tot 1880 , heerschte onder geologen vrij algemeen de opvatting, dat de in den Indischen Archipel gevonden sedimenten alle tot het tertiaire tijdvak behoorden, of nog jonger waren. Alleen voor Timor werd een uitzondering gemaakt, in zooverre dat hier naast tertiaire ook veel oudere lagen moesten voorkomen. Reeds in 1829 vond H. MACKLot $^{2}$ ), een lid van de vóór Junghunn in Indië werkzame "Natuurkundige Commissie", versteeningen op Timor, die later als oud herkend werden. In 1858 kwamen door R. F. DE SEYFF versteeningen van Timor naar Batavia, waaronder zich een ammoniet en encrinieten bevonden ${ }^{3}$ ). In 1862 zag F. vox RicirThofen bij Junghunn eenige fossielen, die deze van Dr. C. F. A. Schneider op Timor ontvangen had, en waarover hij opmerkt: „Es sind Brachiopoden und Crinoidenstiele, unter ersteren zwei grosse Spiriferen, welche an Arten aus dem Bergkalk erinnern. Das Vorkommen einer so alten Formation in diesen Gegenden

I) E. Dubors, 1894. Pithecanthropus erectus aus Java. (Batavia, r894. Ook Jaarb. v. h. Mijnw. Wet. Ged. r895. p. 5-77).

2) Zie hierboven p. II7.

3) Mineralen van Timor, aangeboden door den heer DE SEyff. (Nat. Tijdschr. v. Ned.-Indië. XVI. 1858-59. p. 87). 
war meines Wissens bisher unbekannt" "). (De mededeeling over de collectie-DE SEyfF in het Nat. Tijdschr. v. N.-Indië is hierbij over het hoofd gezien).

In I 864 werd door E. Beyrich een suite versteeningen van Timor beschreven, die eveneens af komstig was van den reeds bovengenoemden Dr. Schneider. Ook Beyrich rekende deze fossielen tot de kolenkalk, zoodat aan het voorkomen van palaeozoïsche lagen op dat eiland niet meer te twijfelen was ${ }^{2}$ ). Latere onderzoekingen van A. RothrLetz hebben intusschen aangetoond, dat deze fossielen iets jonger zijn en tot de permformatie, dus tot het jongste palaeozoïcum moeten gerekend worden $\left.{ }^{3}\right)$.

Tien jaren later, in 1874 , werden door het Mijnwezen (Verbeek, Van Schelle, Fennema) op Sumatra, in de Padangsche Bovenlanden lagen met versteeningen (Phillipsia, Fusulinen enz.) ontdekt, die eveneens palaeozoïsch waren $\left.{ }^{+}\right)$. Zij werden door Ferd. Roener als kolenkalk beschreven ${ }^{5}$ ); G. Fliegel heeft echter waarschijnlijk gemaakt, dat ook deze fossielen iets jonger

1) F. von Richthofen, 1862. Bericht über einen Ausflug in Java. (Zeitschr. d. d. geol. Gesellsch. XIV, I862. p. $327-356$ ) p. 356 .

$\Rightarrow$ E. Beyrich, 1864. Ueber eine Kohlenkalk- (Conchyliën-) Fauna von der Insel Timor. (Abhandl. d. Berl. Akad. d. Wissensch. I864 (gedruckt I865). p. 59-98. Mit 3 Tafeln).

3) A. Rothpletz, 1892. Die Perm.-, Trias- und Jura-Formation auf Timor und Rotti im Indischen Archipel. (Palaeontographica XXXIX, 1892. p. 57-ro6. .lit 6 Tafeln. Ook in Jaarb. v. h. Mijnw., i894. Wet. Ged. p. 5- $\$$ ).

4) R. D. M. VerneEK, 1875. Over den ouderdom der steenkolen van het Oembiliënkolenveld in de Padangsche Bovenlanden en van de sedimentaire vormingen van Sumatra in het algemeen. (Jaarb. v. h. Mijnw., iS75. I. p. 135-I 46).

R. D. M. VERBEeK, I875. De fossielen in den kolenkalksteen van Sumatra's Westkust. (Jaarb. v. h. Mijnw., I875. II. p. I86-189).

5) F. Roemer, i880. Ueber eine Kohlenkalkfauna der Westküste von Sumatra. (l'alaeontographica XXVII, ISSo, p. I-rx. Mit 3 Tafeln. Ook in Jaarb. v. h. Mijnw., 188r. I. p. 289-305). 
zijn, dat ze namelijk niet tot de kolenkalk, maar tot het oppercarboon behooren ${ }^{\mathrm{x}}$ ).

Behalve de genoemde palaeozoïsche lagen van Timor en van Sumatra waren geen andere bekend; men bleef nog 9 jaren lang in de meening verkeeren, dat overigens slechts tertiaire sedimenten in den Indischen Archipel voorhanden waren; de geheele mesozoische periode scheen te ontbreken!

In $188_{3}$ vond de mijningenieur C. J. van Schelle eenige fossielen in mergels van de Wester-afdeeling van Borneo, die door H. B. Geinitz als cretaceïsch bepaald werden ${ }^{2}$ ). Dit was de eerste ontdekking van mesozoïsche lagen in den Archipel. Hierop volgde in 1889 de ontdekking door A. Wichianis van triassische lagen op het eiland Rotti en van jurassische gesteenten op hetzelfde eiland, deze laatste echter niet in vaste lagen, maar als uitwerpsels van slikbronnen (zgn. slikvulkanen ${ }^{3}$ ). En hiermede was de aanwezigheid van de drie hoofdgroepen van het mesozoïcum (trias, jura, krijt) in den Archipel vastgesteld.

$\mathrm{Na}$ het jaar I889 volgen de ontdekkingen van mesozoïsche, gedeeltelijk ook van palaeozoïsche, formaties met verrassende snelheid op elkaar, zoodat in de laatste 25 jaren een volkomen

I) G. Fliegel, I898. Die Verbreitung des marinen Obercarbon in Süd- und Ost-Asien. (Zeitschr. d. d. geol. Gesellsch. L. I898. p. 385-408. Mit Tafel).

G. FliEgel, I90I-I902. Ueber obercarbonische Faunen aus Ost- und SüdAsien. (Palaeontographica XLVIII, I90I-I902. p. 9I-136. Mit 3 Tafeln).

2) R. D. M. VerbeeK, 1883 . Over het voorkomen van gesteenten der Krijtformatie in de residentie Wester-afdeeling van Borneo. (Versl. en Med. Kon.

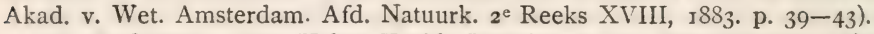

H. B. Geinitz, 1883. Ueber Kreide-Petrefakten von West-Borneo. (Zeitschr. d. d. geol. Gesellsch. XXXV. 1883. p. 205).

3) A. Wichmann, i892. Rotti. p. 222-255.

A. Rothpletz, i89i. On the Permian, Triassic and Jurassic Formations in the East Indian Archipelago. (American Naturalist, I89r. p. 959).

A. Rothplet $z$, I892, t. a. p. 
wijziging plaats had in de tot dien tijd heerschende meening over den geologischen bouw en het successieve ontstaan van onzen Archipel.

Een samenvatting van die nieuwste ontdekkingen gaf VERBEeK in verschillende geschriften, het uitvoerigst in zijn Molukken-verslag ${ }^{x}$ ), meer verkort in Labberton's Geillustreerd Handboek van Insulinde ${ }^{2}$ ) en in den Catalogus van de KoloniaalAardrijkskundige Tentoonstelling te Amsterdam in $1913^{3}$ ).

Wanneer wij nu de op de Indische eilanden tot heden gevonden formatie's met VERBEEK in I 3 groepen onderbrengen, dan kunnen wij den stand onzer kennis van de verspreiding dier verschillende groepen als volgt samenvatten:

I. Oude leigesteenten (Schiefers). Zonder versteeningen, van onbekenden ouderdom. Hieronder zijn waarschijnlijk zoowel archaeische (= azoische), als verschillende oud-palaeozoïsche gesteenten. Tot de laatste behooren vermoedelijk de kleileien met goudhoudende kwartsgangen der Padangsche Bovenlanden, maar totnogtoe is zelfs geen spoor van versteeningen in deze leien aangetroffen. Deze gesteenten zijn zeer verspreid en komen waarschijnlijk overal in den ondergrond voor. Men kent ze van Sumatra, Banka, Billiton, Karimon-Djawa, Borneo, Celebes en talrijke eilanden van de Molukken (deze laatste in ruimen zin genomen, dus met inbegrip van Nederlandsch NieuwGuinea, de Timor-archipel en de Kleine-Soendaeilanden).

2. Groep dor oude basische eruptiefgesteenten, van grooten-

2) R. D. M. Verbeek, I9o8. Molukken-Verslag. Met kaarten en profielen. (Jaarb. v. h. Mijnw., I90S. Wet. Ged. Ook met franschen tekst verschenen).

$\Rightarrow$ R. D. M. VerEeEK, I910. Geologie van den Nederlandsch Oost-Indischen Archipel. (LABbertoxs "Geillustreerd Handboek van Insulinde”. Amsterdam, 19ro. p. I6-22).

3) R. D. M. Verefek, 19I3. De vermeerdering onzer geologische kennis van den Nederlandsch Oost-Indischen Archipel in de laatste 40 jaren. (Catal. Kol. Aardr. Tent. Amsterdam, 20 Sept. -3 r Oct. 19r3. p. $72-78$ ). 
GEOLOGISCHE ONTDEKKINGEN NA 1850.

deels prae-permischen ouderdom; een gedeelte is wellicht jonger (mesozoïsch). Hiertoe behooren peridotiet, gabbro, serpentijn, diabaas en diabaasporfieriet, met hun tuffen, brecciën en schaalsteenen, die met de oude leigesteenten opgericht en geplooid zijn. Zeer verspreid in de Molukken, ook op Sumatra, Celebes en Borneo.

3. Granietgesteenten. Deze zijn in de Molukken jonger dan groep 2, daar ze o. a. op Ambon, Lirang en Wetar gangvormig in peridotiet, diabaas en gabbro optreden. Ze zijn echter tevens ouder dan triassisch, omdat gruis van granieten in de opperpalaeozoïsche, of waarschijnlijker triassische zandsteenen jvan Ambon voorkomt. Andere granieten, namelijk sommige van Djambi en het noordelijk gedeelte van Palembang (de Rawas) zijn echter zeker jonger, daar zij mesozoïsche (waarschijnlijkjurassische) sedimenten contact-metamorph veranderd hebben. Gevonden op Sumatra, Banka, Billiton, Borneo, Celebes, Molukken.

4. Opper-palaeozoïsche lagen (opper-carbonisch en perm) zijn gevonden op Sumatra, Timor en in de Molukken. De door F. Roemer beschreven palaeozoïsche versteeningen van de Padangsche Bovenlanden (Sumatra) en ook die, welke Tobler in 1908 in Djambi vond, zijn opper-carbonisch en verschillen natuurlijk van die van Timor, welke tot de perm-formatie behooren. De zandsteenen van Ambon, die voorloopig als waarschijnlijk opper-palaeozoïsch werden bepaald (I900 G. Вовнм), zijn vermoedelijk niet ouder dan triassisch.

5. Trias-formatie. Deze is volgens de laatste onderzoekingen in de Molukken zeer verbreid. (Rotti i889 A. Wichmann; verschillende Moluksche eilanden I899 R. D. M. Verbeek, 1900 G. Boehm, 1907 J. Wanner en H. Hirschi; Boeroe I909 L. Krumbeck), maar komt ook voor op Timor (I89i ten Kate), op Sumatra (Noord-Sumatra I 899 W. Volz; Padangsche bovenlanden I9I 2 L. KRUmbeck) en Borneo (West-Borneo Igo2 Wing- 
EAston en Vogel). Nagenoeg alle gevonden steenen zijn uit de opper-trias afkomstig; versteeningen uit de onder-trias komen ook voor, maar zijn totnogtoe uiterst zeldzaam. De kalksteenen dezer formatie, gedeeltelijk verkiezeld, bevatten talrijke radiolariën, ook echte radiolarieten zijn voorhanden. De opper-triassische versteeningen komen gedeeltelijk ook in den Himalaya en in de Alpen voor.

De voor rhätisch gehouden plaatkalken van de Padangsche bovenlanden (I908, Miss M. HEALEY), welke fossielen bevatten, die ook op Boeroe en op Misool voorkomen, behooren zeer waarschijnlijk ook tot de opper-trias; evenzoo de oorspronkelijk als opper-cretaceisch beschouwde donkere kalksteenen van Boeroe met ammonieten, die eerst voor Tissotia's gehouden zijn, maar tot de echte Ceratieten behooren. Daarentegen komen wel rhätische lagen voor in het Maleische schiereiland en in opper-Burma.

6. Fura-formatie. Jurassische lagen zijn bekend van verschillende Molukken-eilanden (Rotti 1889 Wichnians; Boeroe IS92 MArtiN; andere Moluksche eilanden IS99 Verbeek; I900 G. Boemin), verder van Borneo (IVest-Borneo i 895 -96 Martix; Vogel en Krause; Noord-Borneo i 897 Bullen-Neivton) en Sumatra (Djambi igo8 Tobler). Verschillende etage's der drie jura-afdeelingen (lias, dogger, malm) zijn gevonden, met talrijke ammonieten en belemnieten, die gedeeltelijk groote gelijkenis vertoonen met de jurassische van Britsch-Indië, benevens van Zwitserland en van $Z$ waben.

7. Krijt-formatie. In de Molukken zijn onder-cretaceïsche lagen met ammonieten enz. gevonden op Misool, Taliabo, Nangoli en Nieuw-Guinea (IS99 Verbeek; igoo G. Boemm). Van Borneo's Westkust ( $18 S_{3}$ Geinitz) zijn kalksteenen met orbitolinen (cenomaan?) bekend; terwijl op Sumatra zoowel neocoom-lagen met hoplieten in Djambi (I906 ToBler), als jons-cretaceische sedimenten in Langkat voorkomen. 
GEOLOGISCHE ONTDEKKINGEN NA I 850 .

S. Emptiefgesteenten der mesozoïsche periode, hoofdzakelijk melafieren (die wellicht gedeeltelijk nog permisch zijn), kwartsporfieren, kwartsporfierieten, diabazen en diabaasporfierieten, benevens enkele granieten. Men vindt ze vooral in de Zuideren Oosterafdeelingen van Borneo en in de Molukken (Ambon o.a.), maar ook op Java en Sumatra.

9. Ond-tertiaire (eoccene en oligoceene) afisettingen zijn reeds lang bekend van Borneo en Java, maar zijn ook in de Molukken zeer verbreid (I 899 eoceen VERBEEK). Zij behooren tot den grooten gordel van nummulieten-gesteenten, die zich van ZuidEuropa en Noord-Afrika door Britsch-Indië en NederlandschIndië tot aan Nieuw-Caledonië uitstrekt. Mergelschiefers van de Padangsche Bovenlanden met fraaie fossiele visschen en planten, worden door sommigen voor eoceen, door anderen voor oppercretaceisch gehouden. Nummulieten zijn van Sumatra merkwaardigerwijze nog niet bekend. Tot de eoceene formatie behooren de goede steenkolenlagen van Sumatra (Oembiliën) en van Borneo.

ro. De mioccene formatie bestaat gedeeltelijk uit eruptiefgesteenten, gedeeltelijk uit grof en fijn, zanderig, mergelig en kalkhoudend gruis van deze gesteenten in zee afgezet en met talrijke fossielen. Niet alleen de zandsteenen en mergels, maar zelfs de schijnbaar zuivere kalksteenen dezer formatie bevatten steeds een belangrijke hoeveelheid andesietisch of basaltisch materiaal, afkomstig van de mioceene eruptiefgesteenten. Dit gruis wordt in de eoceene nummulietenkalken geheel gemist, hetgeen bewijst, dat de andesieten en bazalten eerst na de vorming van dien kalksteen ontstonden. Naast andesiet en bazalt, die veelvuldig voorkomen, vindt men ook enkele leucieten nepheliengesteenten, welke de oudste zijn onder de mioceene eruptiefgesteenten. Mioceene gesteenten komen op de meeste eilanden van den Archipel voor, maar niet op Banka, Billiton, 
Ambon en enkele andere. De ligging van de totnogtoe grenoemde sedimenten is zelden horizontaal, meestal door plooiing en oprichting gestoord.

I1. Plioccene sedimenten. De jongste tertiaire sedimenten bestaan op Sumatra en Java uit zandsteenen, op de Molukken daarentegen uit kalksteen; zij vormen hier de oudste, in terrassen optredende koraalkalken, terwijl de jongere kalkterrassen tot de kwartaire periode behooren. De plioceene lagen vertoonen nog geringe hellingen; hoe jonger de laag, hoe meer de ligging tot de horizontale nadert.

12. De kwartaire periode omvat vooreerst de groote rulkanische kegelbergen, die wel reeds in den jong-tertiairen tijd ontstonden en gedeeltelijk ook in de hedendaagsche periode werkten of nog werken, maar hoofdzakelijk in den kwartairen tijd door ophooping van eruptie-produkten om een krater werden opgebouwd. Kwartaire sedimenten op Java en Sumatra bestaan uit gruis van jong-vulkanische gesteenten, op Borneo uit gruis van oudere gesteenten en op de Molukken deels uit vulkanisch materiaal (losse zandsteenen), deels uit terrasvormige koraalkalken. Hun ligging is vrijwel horizontaal.

I3. De recente of hedendaagsche vormingen bestaan hoofdzakelijk uit kalksteen, die voortdurend nabij de kusten en ook verder van de kusten in ondiepe zee door den bouw van koralen, foraminiferen en kalkalgen ontstaan. Verder uit vulkanische uitwerpselen, uit afzettingen van rivieren aan hun uitmonding in zee, waar ze soms belangrijke delta's vormen: eindelijk uit afzettingen van warme bronnen.

Tot zoover een uiteenzetting van de door het geologisch na 1880 ontdekte feiten, in hoofdzaak aan VERBEEK's overzichten ontleend. De conclusies, waartoe deze gegrevens leiden, stellen ons in staat in grove trekken een wordingsgeschiedenis van den Indischen Archipel op te bouwen. Kalkafzetting wijst op 
ondiepte der zee of op zoetwater; in diepe zeeën wordt kalk door de heerschende drukking opgelost; waar dus kalksteen gevonden wordt, is of een ondiepe zee, ò zoetwater geweest. Overeenkomst in fossiele zeefauna in verschillende streken der aarde wijst op een zeeverbinding, welke in dien tijd bestaan moet hebben; zoo is bijw. het verband tusschen trias en jura in onzen Archipel, in Voor-Indië, in den Himalaya, in de Alpen van enorme beteekenis voor een reconstructie van het kaartbeeld onzer aarde in die overoude tijden. Van perm tot eoceen en oligoceen bestond zeer waarschijnlijk een openzeeverbinding, die misschien zelfs tot het eind van het oud-mioceen (volgens MartiN ${ }^{2}$ ) zou reeds in het eoceen een landmassa, die de Indische en Middellandsche zeeën scheidde, aanwezig geweest zijn) den Indischen Archipel over den tegenwoordigen Himalaya met de Zuid-Europeesche zee verbond; een ontzaglijke zee, die zich benoorden Australië nog ver oostelijk uitstrekte, zeker tot Nieuw-Caledonië en Nieuw-Zeeland, mogelijk nog verder. Reeds in het jong-carboon was Australië volgens deze theorie van China door die zee gescheiden. Deze zeeverbinding komt overeen met de door SuEss ontworpen Thetys, het Grosse Mittelmeer van Necmayr en de Mésogée van Douvillé. De landmassa, die volgens Necmayr het sino-australisch continent zou vormen, heeft echter nooit bestaan, aangezien daar ter plaatse in onzen Archipel juist marine jura-versteeningen gevonden zijn. De sedimenten in onzen Archipel werden in die zee afgezet en door zijdelingsche persing der omringende landmassa's gedeeltelijk boven water gebracht, zoodat eilanden ontstonden. De ondiepe zee rondom die eilanden gaf dan een geschikte afzettingsplaats voor kalkgesteenten; over het algemeen

I) K. Martin, Igry. Wann löste sich das Gebiet des Indischen Archipels von der Thetys? (Sammlungen geol. Reichmuseums. Leiden, IX. 1914. p. 337-355). p. 349 . 
waren diepe gedeelten in deze zee zeldzaam, alleen het voorkomen van radiolarieten in de Jura-formatie wijst op plaatselijk groote diepten. Gedurende het eoceen en oligoceen verhief de zeebodem zich steeds meer, totdat tijdens het mioceen, vooral in het laatste gedeelte van dit tijdvak, groote instortingen plaats hadden, waardoor de zeediepte hier en daar sterk toenam, met name in den Indischen Oceaan, de Banda-Zee, de Celebes-Zee en andere bekkens. Daardoor zouden dan de bijzonder diepe gedeelten der Indische zeeën ontstaan zijn, die thans tusschen 1000 en 6500 Meter diepte bereiken. Vanaf het plioceen hebben weer voortdurend opheffingen plaats, ook in het diepe gedeelte, welk proces nog heden ten dage schijnt voort te gaan, afwisselend met tijdelijk geringere verzakkingen.

In verband hiermede zijn van belang de gegevens dout moderne oceanographische onderzoekingen geleverd, namelijk dat de zee tusschen Sumatra, Java, Borneo en zuidoostelijk Azië overal zeer ondiep, op sommige punten zelfs niet dieper dan 45 Meter is, zoodat al deze landen liggen op een vlak onderzeesch plateau dat vermoedelijk in jong-plioceenen tijd land geweest is. Evenzoo liggen Australië met Nieuw-Guinea op een onderzeesch plateau en zouden deze eilanden bij een rijzing van slechts 20 Meter verbonden worden. De zee tusschen beide genoemde plateau's, waarin dus de Kleine-Soenda-eilanden, Celebes en de Molukken liggen, is daarentegen overal dieper dan 200 Meter; in de Molukken wisselen deze diepten voornamelijk tusschen 200 en I000 Meter, overigens bedragen ze meer dan 1000 Meter.

De gevolgtrekkingen, die reeds nu te trekken zijn uit onze kennis van den geologischen bouw der Nederlandsch-Indische eilanden, vergeleken met hetgeen over de geologie van andere streken der aarde bekend is en in verband met wat talrijke 
onderzoekers, zooals E. Suess ${ }^{2}$ ), E. HavG ${ }^{2}$ ), A. Rothiletz ${ }^{3}$, P. Lemone ${ }^{4}$ ) en anderen in den laatsten tijd hebben geleerd, heeft Verreek het eerst samengesteld in zijn Molukken-Verslag $\left.(\mathrm{I} 908)^{5}\right)$. In zijn twee jaar later verschenen geologisch overzicht in Labbertons Handboek $(1910)^{6}$ ) vindt men hierover het volgende:

„Een voornaam feit in de geologie van Nederlandsch-Indië is, dat al de marineafzettingen van onzen Archipel steeds in éénzelfde zee plaats hadden, welke zee eertijds de noordelijke begrenzing uitmaakte van een groot continent, dat Zuid-Amerika, bijna greheel Afrika met Arabië, Britsch-Indië en Australië omvatte. Door een groote scheur langs de Oostkust van Afrika werd dit land in het begin der Liasperiode, misschien reeds iets vroeger, in twee stukken verdeeld, een AfrikaanschBraziliaansch en een Oud-Indisch Continent; en ook later, in de Jura-formatie en in de Krijt-formatie, ontstonden in dit land groote scheuren en inzinkingen, zooals jurassische lagen aan de Westkust van Australië en jong-cretaceissche lagen aan de Oostkust van Madagascar bewijzen. Maar groote landmassa's bleven toch bestaan, totdat aan het begin der plioceene periode de groote instortingen plaats hadden, die niet alleen in onzen Archipel zeer diepe bekkens deden ontstaan (Banda-zee enz.), maar zelfs een groot gedeelte van het Oud-Indisch Continent deden verdwijnen, zoodat daarvan tegenwoordig alleen Mada-

2) E. Suess, I883-1909. Das Antlitz der Erde I, I883; II, I888; III I, 1901; III 2, 1909 .

2) E. Haug, 1900. Les géosynclinaux et les aires continentales. (Bull. Soc. géol. France $3^{\mathrm{e}}$ série XXVIII, 1900. p. 617-7II).

3) A. Rothpletz, I891-92. t. a. p.

4) P. Lemoine, 1906. Etudes géologiques dans le Nord de Madagascar. (Paris, 1906).

5) R. D. M. VeRBEEK, 1908. p. 809-8I8.

6) R. D. M. VerbeEK, 1910. p. 22. 
gascar, het Britsch-Indische Schiereiland en Australië overgeschoten zijn. Ook het zuidelijk gedeelte van den Stillen Oceaan schijnt eerst toen gevormd te zijn".

Hypothetisch zal het karakter van deze en dergelijke uitspraken tot op zekere hoogte altijd blijven; zonder hypothese is echter wetenschap onbestaanbaar, en het toekomstig geologisch onderzoek van onzen Archipel, op welk gebied VERBEEK één der baanbrekers is geweest, zal ons leeren, in hoeverre de hypothese met de feiten overeenstemt, in hoeverre ze dus den naam theorie zal mogen dragen; mocht het later blijken, dat Verbeek's opvatting niet in alle opzichten juist geweest is, zijn werk blijft, en daarop kan thans voortgebouwd worden. Veel arbeid zal er nog moeten verricht worden, veel geologische studiën zullen nog moeten geschieden, voordat het beeld, hierboven in grove trekken geschetst, volkomen de ontwikkeling van onzen Archipel in den loop der geologische perioden zal kunnen weêrgeven. Daarin ligt een mooie taak en een dankbare werkkring voor onze Indische geologen en mijningenieurs. 


\section{HOOFDSTUK XI.}

\section{Natuurkundige aardrijkskunde na $\mathbf{1 8 5 0 .}$}

Het was in het begin van $1 \delta_{5} 6$, dat de oud-minister PAHUD, benoemd tot Gouverneur-Generaal van Nederlandsch-Indië, te Berlijn, waar hij op reis naar Indië vertoefde, Alexander von Humbold ontmoette; deze trachtte hem te bewegen te Batavia een Meteorologisch en Magnetisch Observatorium op te richten. Indië was meteorologisch nog weinig bewerkt: Dr. P. L. Onnen had er tusschen 184 I en 1846 waarnemingen met barometer, thermometer, psychrometer, over wind en over onweer, gedaan; de Engelsche Captain Elliot had de magnetische equator en de ligging van isogonen en isoklinen trachten te bepalen; Junghunn deed waar hij kwam observaties en bewerkte ze in het stuk over klimaatbeschrijving van zijn ,Java" tot zijn verdeeling in verschillende hoogtegordels; maar van een opnemingsstelsel was nog geen sprake. En juist in verband met den goed georganiseerden opnemingsdienst der Engelschen onder leiding van SABiNE, was het van groot belang, ook in onze koloniën waarnemingen te doen verrichten.

Van Humboldt's voorstel is een correspondentie tusschen Pahud en den Minister, Mr. P. Mijer, het gevolg; adviezen van 



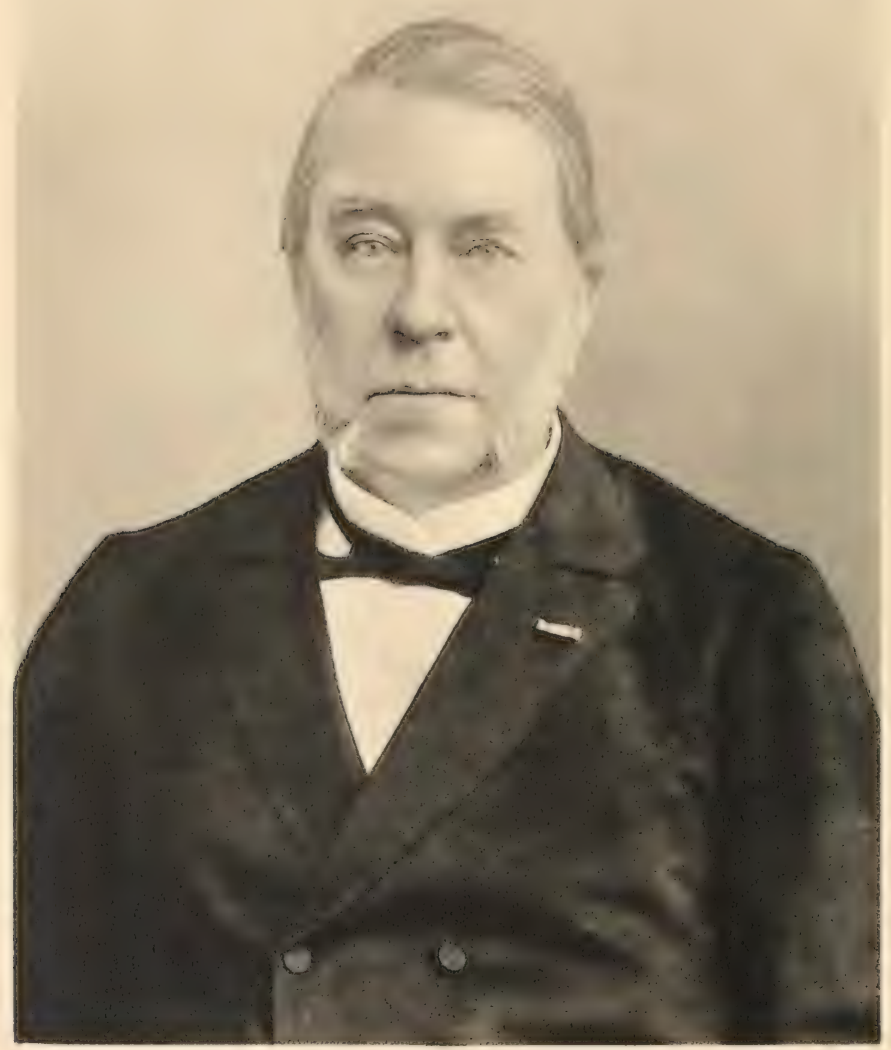

J. A. C. OUDEMANS. 
J. A. C. Oudemans en Buys Baldit waren oorzaak, dat tot oprichting van een Meteorologisch-Magnetisch Observatorium besloten werd, en dat de organisatie van deze instelling opgedragen werd aan Dr. P. A. Bergsis ${ }^{1}$ ). Oorspronkelijk had de Minister Otdemans zelf gevraagd, die echter, afgetreden als buitengewoon hoogleeraar te Utrecht en benoemd tot hoofdingenieur van den geographischen dienst in Ned.-Indië, het beheer van het Observatorium onvereenigbaar achtte met zijn eigen werkkring. Terwijl Oudemans tijdens zijn Indische periode (1858-1875) de triangulatie van Java organiseerde en voor het grootste deel zelf ten uitvoer bracht, deed hij bovendien waarnemingen tijdens den overgang van Mercurius voor de zon (IS6I), over totale zoneclipsen en verbeterde hij de lengtebepaling van Batavia, o. a. reeds door Morr ${ }^{2}$ ) berekend.

Zijn vriend, Dr. Pieter Adriala Bergsia (geboren 23 April I 830 te Gent, bracht zijn jeugd door en studeerde te Utrecht, waar hij I September 1854 tot Doctor in de Wis- en Natuurkunde bevorderd werd op een dissertatie: „Over de phosphorescentie door bestraling"), werd benoemd met opdracht, het door Buys Ballot ontworpen programma uit te voeren. Dit programma was vierledig: Ie de oprichting van een MagnetischMeteorologisch Observatorium te Batavia; ze het stichten van stations der $2 \mathrm{e}$ orde voor gelijksoortige waarnemingen in den

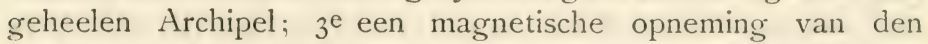
Archipel en $4^{\mathrm{e}}$ de opzending van alle waarnemingen naar Utrecht. In den loop van 1859 en 1860 bezocht BERGsMA, als ingenieur van den geographischen dienst in Ned.-Indië, de inrichtingen

1) Zie J. A. C. Oudemans, i8Sz. Levensschets van Dr. P. A. Bercisis. (Jaarb. K. A. W. Amsterdam, 1882. p. $98-\mathrm{r}_{30}$, met ${ }_{4}$ bijlagen. p. 130-152).

J. P. v. D. Sток, 1913. Natuurkundige Aardrijkskunde van den Oost-Indischen Archipel. (Catalogus Kolon. Aardr. Tentoonst. 19r3. p. 66-7I).

2) Zie p. 7 I. 
NATUURKUNDIGE AARDRIJKSKUNDE NA 1850.

van S.ibine en Lloyd in Engeland en Ierland, daarna Göttingen, Bonn, München en Weenen, om in October 186 I het vaderland voorgoed te verlaten ten einde zijn bestemming te volgen.

Talrijk waren de moeilijkheden, die hij in Indië te overwinnen had; zijn voorstel om een som van $f 50,000$ beschikbaar te stellen voor aankoop en inrichting van een voor observatorium geschikt huis, werd, hoewel ondersteund door alle tot oordeelen bevoegde personen, om finantieele redenen door den Raad van Indië verworpen, en nadat deze, op één lid na, door Bergsma overtuigd was van het noodzakelijke dezer uitgaaf, toch door den nieuwen G.-G. Sloet van dE BeEle afgekeurd. Zoo moest Bergsina zich I4 jaar lang tevreden stellen met tijdelijke inrichtingen; de voortdurende wisselingen van G.-G. en Minister van Koloniën (na Mr. P. Mrjer, I 858 waren er tot 1873 , het jaar waarin tot den bouw van een goed observatorium besloten werd, niet minder dan tien Ministers van Koloniën geweest) werkten ook zeer ongunstig op het doorvoeren der plannen, en toch hield Bergsma vol. Gedurende den bouw en de inrichting van het nieuwe observatorium (I874-I877) had hij hulp van den luit. t. zee BAcker Overbeek als onderdirecteur; deze werd opgevolgd door Dr. J. P. v. D. STok.

Voorloopig kon alleen het eerste punt van Buys BALLot's programma ten uitvoer gebracht worden: I Januari I 866 werd met het systematisch onderzoek een aanvang gemaakt en de waarnemingen nedergelegd in het eerste deel van de ,Observations made at the Magnetical and Meteorological Observatory at Batavia" (187I), een steeds voortgezette publicatie, waarvan thans het $34^{\mathrm{e}}$ deel op verschijning wacht. In deze "Observations" worden alle door het Observatorium gedane waarnemingen over barometerstand, windrichting en windsnelheid, grondtemperatuur, intensiteit en duur van zonneschijn, later (sedert I883) ook electrische potentiaal van den dampkring en magnetische obser- 
vaties en (sedert $1 S 9 S$ ) ook onderzoekingen over de bewegingen van den aardschors verwerkt en uitgegeven. Vanaf deel io (1S87) verschijnen de Observations in jaarlijksche deelen; het I 3 e deel (I 890 ) bevat een overzicht over de 25 -jarige werkzaamheid; deel I8 (I895) over de periode I866-I895, terwijl sedert dien vijfjaarlijksche overzichten gegeven worden.

Maar ook een ander punt had BERGSMA's aandacht getrokken: een nauwkeurig overzicht te geven van den regenval in Indic: De resultaten van de eerste met hulp van den Chef van den Geneeskundigen Dienst Wassink aan de officieren van gezondheid opgedragen regenwaarnemingen, bleken door slordige bewerking onbruikbaar; BERGsia riep de hulp van belangstellende particulieren in en slaagde erin, vanaf 1879 geregelde ,Regenwaarnemingen" te publiceeren, oorspronkelijk met it stations op Java en 44 op de Buitenbezittingen (in $18 \$_{+}$in totaal 172 , thans 1660 ).

Met het derde punt van het programma, een magnetische opneming van den Archipel, kon Bergs.u, wiens geheele werkkracht door de Bataviasche waarnemingen in beslag genomen werd, nog geen aanvang maken; aan een particulier Dr. E. r... Rickevorssel uit Rotterdam, danken wij deze onderzoekingen (1874-1877), uitgegeven door de Koninklijke Academie van Wetenschappen te Amsterdam. Bergsma was zoo verstandig, het vierde punt der opdracht als niet geschreven te beschouwen, maar zelf alle waarnemingen uit te werken en te publiceeren.

Na twintigjarig verblijf in Indie, vertrok BERcisia in het voorjaar van 1882 met verlof naar Europa, maar zou het vaderland niet weerzien: I Mei I 882 overleed hij aan boord in de Roode Zee. In twee opzichten was het jaar 1882 voor het Observatorium van beteekenis: een nieuwe Directeur, Dr. J. P. v. D. STuk. verving den man, wien deze wetenschappelijke instelling, het eerste geophysisch instituut in de tropen, inrichting en levens- 
NATUURKUNDIGE AARDRIJKSKUNDE NA I 850 .

kracht dankt, en tevens werd in dit jaar het Observatorium losgemaakt van den geographischen dienst en onmiddellijk onder het Marine-Departement gebracht.

Het oordeel van ambtenaren en bestuurders over Bergsma's arbeid was niet gunstig; één der Gouverneurs-Generaal (Oct. I870) meende hem zelfs te mogen verwijten, dat hij nog niet alle in Engeland aangekochte instrumenten in gebruik genomen had, terwijl hij naar de meening van Zijne Excellentie ,het eigenlijke doel der zending ter zijde gesteld had". En dat terwijl de regeering hem voortdurend moeilijkheden in den weg legde en hem nog steeds geen gelegenheid gaf, zijn werkzaamheden te regelen!

Maar daartegenover staat het oordeel van een bevoegd persoon, als den directeur van het "Centralanstalt für Meteorologie und Erdmagnetismus" te Weenen Hans, die na het verschijnen van het eerste deel der Observations verklaarde: „Dr. Bergsma hat eine riesige Arbeit geliefert”, en later in zijn „Klimatologie" ${ }^{x}$ ) dit getuigenis geeft : „Es giebt nur ganz wenige Punkte der Erde von denen wir so detaillierte Kenntnisse über alle meteorologischen Elemente haben, sowohl in Bezug auf die Mittelwerthe als auch auf die periodischen und unperiodischen Veränderungen, wie dies für Batavia der Fall ist". En dat is toch aan de werkkracht van Bergsma en zijn opvolgers te danken.

Alle met meteorologie samenhangende richtingen van onderzoek worden door het Observatorium beoefend; behalve de meteorologische studies en regenwaarnemingen door BERGsma begonnen, werd na hem onder de leiding van Dr. J. P. v. D. SToK (I882-i899), Dr. S. Figee (i 899-igo8) en Dr. W. v. Bemmelen (1908-thans) een aanvang gemaakt met seismologische waar-

2) J. HanN, I897. Handbuch der Klimatologie II. I. Tropenzone. (2e Ed, p. 236). 



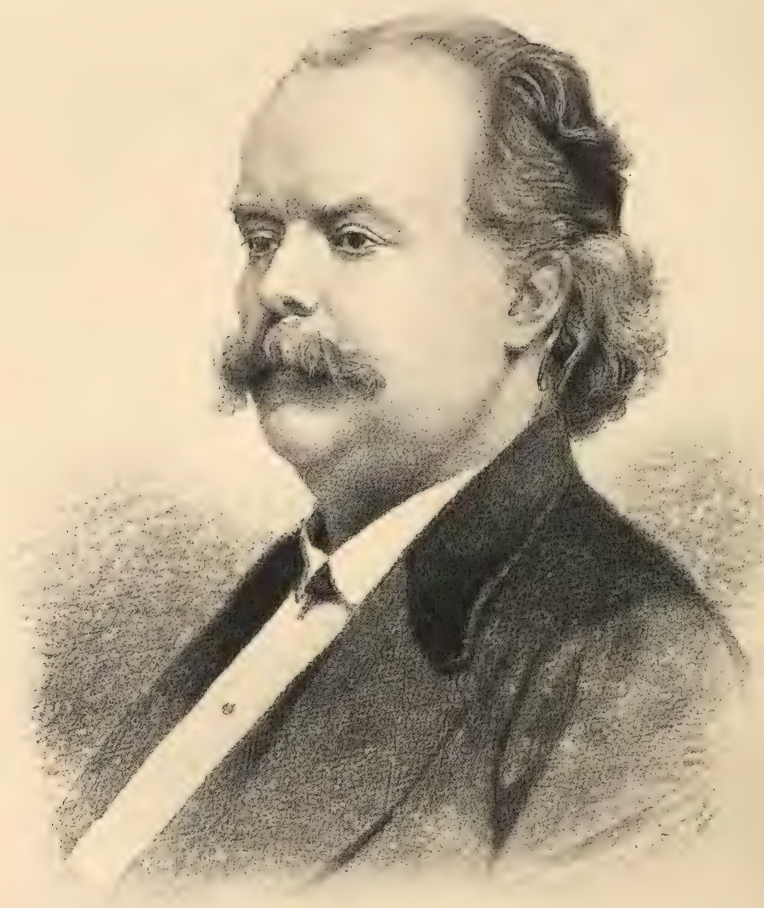

P. A, BERGSMA. 
nemingen, met onderzoek der hoogere luchtlagen, met oceanosraphie en getijdenstudie enz. Het onderzoek van de beweyingen der aardkorst werd oorspronkelijk door een afzonderlijke seismologische commissie behartigd (IS83-1898), terwijl de resultaten een plaats vonden in het Natuurkundig Tijdschrift van Ned.-Indië ${ }^{\mathrm{x}}$ ) maar na $\mathrm{s} 89 \mathrm{~S}$ door het Observatorium, dat dan ook sedert Juli 1898 aan deze waarnemingen een plaats in zijn "Observations" verleende.

Het zgn. wolkenjaar 1896-97 was aanleiding, dat met het onderzoek der hoogere luchtlagen door internationale samenwerking een begin gemaakt kon worden, waartoe HiLdebrandsson het initiatief genomen had. Batavia's Observatorium verleende hieraan krachtige medewerking. Met behulp van twee photographische theodolieten werden hoogte en drift van de verschillende wolkensoorten gemeten. De in I896 gedane waarnemingen en de berekeningen door v. D. Stok en FigeE werden eerst veel later door FigeE gepubliceerd ${ }^{2}$ ). En thans, na 1909 wordt dit onderzoek voortgezet door Dr. van Bemielen en zijn onderdirecteur Dr. C. BraAk, die daarbij de nieuwste hulpmiddelen: vliegers, loodsballons en ballons met registreerinrichting tot hun beschikking hebben. De waarnemingen op dit gebied worden sepubliceerd in een nieuwe uitgave van het Observatorium: .,Verhandelingen" 3), terwijl Dr. van Bemmelen kort geleden een samenvattend overzicht ${ }^{4}$ ) over de verkregen resultaten gegeven heeft. Belangrijk is bijvoorbeeld het aantreffen van een lucht-

ז) Natuurkundig Tijdschrift voor Ned.-Indië. Deel $46-7$ I. (I $8 S_{3}-1912$ ).

$\Rightarrow$ S. Figee, roio. Report on Cloud-Observations at Batavia, made during the International Cloud year, 1896-r897.

3) Verhandelingen van het Koninklijk Magnetisch-Meteorologisch Observatorium. $\mathrm{N}^{\circ}$. I. (1890) en $\mathrm{N}^{\circ} .2$ (1912).

4) W. van Bemmelen, 1913. Die Erforschung des tropischen Luftozeans in Niederländisch-Ost-Indiën. (In: Luftfahrt und Wissenschaft, herausgegeben von J. Sticker. Berlin, 1913). 
temperatuur van $-87^{\circ} \mathrm{C}$. op een hoogte van $16 \mathrm{~K}$. M. boven de aarde; verder de waarneming van verschillende luchtstroomingen boven elkander, o. a. van een sterke oostenwind met een snelheid van $34 \mathrm{M}$. per seconde, ongeveer $30,5 \mathrm{~K}$. M. boven de aarde.

Bovendien werd in de jaren 1903-1907 een nieuwe magnetische opneming van den Indischen Archipel door Dr. van Bemmelen verricht, ten einde de waarnemingen te kunnen vergelijken met de door Dr. v. Ryckevorssel ( $1874-1877^{\mathrm{I}}$ ) verkregen resultaten.

Dat het werk, door het Observatorium tot stand gebracht, niet louter wetenschappelijk belang heeft, maar ook aan de practijk goede diensten bewijst, is gebleken zoowel door een aan het Observatorium gevraagd advies (1890) over een gunstige legerplaats voor troepen in de Preanger, als door de krachtige medewerking van landbouw-inrichtingen, door het Observatorium ondervonden bij de samenstelling der Regenwaarnemingen. Ook hier heeft de samenwerking tusschen theoretische onderzoekers en practische werkers het wetenschappelijk en het publiek belang zeer gebaat.

En in den jongsten tijd is Dr. BRAAK, in navolging van hetgeen reeds voor 30 jaar in Engelsch-Indië verricht was, begonnen met een studie van de grondslagen, waarop een weersvoorspelling, voornamelijk tijdens den Oost-Moesson zou kunnen worden gebaseerd. Voorloopig zijn hiermede nog geen belangrijke resultaten bereikt; het heeft er echter allen schijn van, dat binnenkort eenige der voornaamste weerbepalende factoren ontdekt zullen worden.

Oceanographie en getijdenstudie werd aan het Observatorium vooral door Dr. v. D. STOK beoefend, wiens publicaties over dit

${ }^{2)}$ Zie p. 257 . 
onderdeel in verschillende tijdschriften ${ }^{x}$ ) te vinden zijn, terwijl kort geleden een tweetal samenvattende werken ${ }^{2}$ ) van zijn hand verschenen. Voortbouwend op de door den bekenden oceanorraaf G. H. DARWIN aangegeven methode van getijderegistreering werd door v. D. STок een getijbepaling ingevoerd en een getijdienst ingesteld, die omstreeks 80 stations van waarneming omvatte. Sedert 1908 worden door het Observatorium getijtafels samengesteld voor Pontianak, Belawan Deli, Oost- en Westgat van Soerabaja, Oedjoeng Panka, Bandjermasin, Moeara-djawa en Palembang. Zoodoende is de verticale beweging der Indische zeeën thans voldoende bekend, de horizontale bewegingen, d. w. z. getij- en moessonstroomingen zijn echter nog bijna niet onderzocht.

Daarentegen is het met de kennis van den vorm der zee veel beter gesteld; de vertikale vorm, d. w. $z$. de diepte der verschillende Indische zeeën, had vóór I $\$ 70$ nog een eenigszins mystiek waas over zich; alleen die wateren, waar schepen ankeren konden, werden onderzocht en hun diepte gemeten. ,Diepten boven Ioo vademen ( \pm ISo Meter) komen op de zeekaarten dezer streken van vóór 1870 slechts sporadisch voor. Betrouwbare gegevens omtrent de vraag of de diepten in de binnenzeeën van den archipel bij honderden, dan wel bij duizenden vademen waren te rekenen, had men nog slechts op enkele punten" $\left.{ }^{3}\right)$. Daarin is nu na 1870 een ingrijpende en

1) Versl. en Med. K. A. W. Amsterdam, I889; Tijdschr. Kon. Inst. v. Ingenieurs, I890-1896; Natuurk. Tijdschr. v. N.-I., I896.

2) J. P. v. D. Stok, 1897. Wind and Weather, Currents, Tides and Tidalitreams in the East-Indian Archipelago. Batavia, 1897.

J. P. v. D. Sток, rgro. Elementaire Theorie der Getijden. Getijconstanten in den Indischen Archipel. (Kon. Ned. Met. Inst. N ${ }^{\circ}$. roz. Med, en verh. S) Utrecht, rigro.

3) G. F. Tydeman, r913. De oceanographie van den Oost-Indischen Archipel. (Catalogus Kolon. Aardrijksk. Tent. Imsterdam, 20 Sept.-31 Oct. ז913. p. $5 i-65)$. p. 59). 
NATUURKUNDIGE AARDRIJKSKUNDE NA 1850.

gunstige verandering gekomen: de expeditie van de „Lightning” onder bevel van Wyville Thouson (1868) was hier de baanbreker; de "Challenger" (1872-1876) volgde, en daarna tal van andere schepen en expedities, niet het minst door de „Siboga", het Nederlandsche expeditieschip onder leiding van den Luitenant t. Zee ie klasse (thans Vice-Admiraal) G. F. Tydeman ") en Max Weber. $\mathrm{Na}$ het succesvolle Siboga-werk waren het vooral kabelleggers en schepen met wetenschappelijk doel uitgerust, maar ook wel opnemingsvaartuigen van onze Marine (H. M. Opnemingsvaartuigen „Bali”, „Borneo” en „van Gogh”, H. M. Flottieljevaartuig "Edi", het Duitsche Onderzoekingsschip „Planet”, de Engelsche Kabellegger „Magnet” en het Engelsche Oorlogsschip „Fantome”), aan wier waarnemingen belangrijke gegevens omtrent de diepte der Indische zeeën ontleend konden worden. Met hoe groote moeilijkheden het dieplooden vroeget aan boord van daartoe niet speciaal uitgeruste schepen te kamper. had, blijkt wel uit het feit, dat de Siboga een diepte van 4000 Meter vond op een plek in de Banda-zee, nabij welke vroeger door een oorlogschip de zeediepte op 7200 Meter bepaald was. De moderne onderzoekingen, waarbij geen touw, maar staaldraad gebruikt werd en waarbij loodingswerktuigen dienst deden, geconstrueerd volgens het door den Amerikaanschen zeeofficier BRooke aangegeven beginsel, zoodat het grootste deel van het gewicht op den zeebodem achterblijft, hebben in oudere waarnemingen tal van fouten doen zien en hebben thans een vrij goed overzicht over de ligging van den zeebodem tot resultaat gehad. Oceanographisch werk heeft o. a. de aanwezigheid ge toond van twee onderzeesche plateau's, waarop Java en Sumatra met Borneo en Nieuw-Guinea met Australië gemeenschappelijk

r) G. F. Tydeman, r903. Hydrographic results of the Siboga-expeditior. (Uitkomsten der Siboga-expeditie. Monographie III, I9०3. 93 pp.). 
rusten. TyDEMAN ${ }^{2}$ ) vat het resultaat als volgt samen: „In zijn westelijk gedeelte maakt de zeebodem van den archipel deel uit van een uitgestrekt ondiep plateau, samenhangend met het aziatisch vastland en aan zijn west- en zuidzijde begrensd door de groote diepte van den indischen oceaan; in het oostelijk gedeelte van den archipel een afwisseling van hoogte en diepte, met opvallend smalle, langgerekte en in vele gevallen gebogen bodemverheffingen. De daartusschen besloten inzinkingen van den bodem hebben over het algemeen groote diepten en zijn, hoewel aan de oppervlakte overal met elkâar en met de oceanen in verbinding staande, op bepaalde diepten van elkâar en van de oceanen geïsoleerd door onderzeesche ruggen". De temperatuurwaarnemingen door de "Challenger", de "Valdivia", de "Siboga" e. a. verricht hebben aangetoond, dat de temperatuur van het water dezer bekkens slechts afneemt tot aan de diepte, waarop zij van den oceaan zijn afgesloten en daarbeneden constant blijft. Evenzoo is door de onderzoekingen in onzen archipel de waarneming van den "Challenger" bevestigd, dat op ongeveer 200 Meter beneden het zeeoppervlak een plotselinge snelle daling van temperatuur plaats vindt en daarna in een zeer langzame daling overgaat. De oceanograaf der ,Valdivia", G. Sснотт, heeft voor dit verschijnsel een verklaring ${ }^{2}$ ) gegeven: het water aan de oppervlakte verdampt, zoodat het meer zouthoudend wordt, daardoor in soortelijk gewicht toeneemt en zoover daalt, dat het kouder water van gelijk soortelijk gewicht ontmoet. Zoodoende heeft in de oppervlakkige laag ter dikte van ongeveer 200 Meter warmte-uitwisseling door vermenging plaats, daarbeneden alleen door de zeer

х) G. F. Tydeman, 1913. p. 62 .

2) G. SchotT, 1902. Die Sprungschicht der tropischen Meere. (In: Wiss. Ergebn. d. Deutschen Tiefsec-Expedition auf dem Dampfer Valdivia, 1 $\$ 9 S-1899$. Herausgeg. von C. Chun. Band I, 1902. $\S .36$. p. 178-185). 
NATUURKUNDIGE AARDRIJKSKUNDE NA I 850.

langzaam werkende geleiding. Dicht boven de grenslijn van ongeveer 200 Meter heeft het zeewater dus een veel hoogere temperatuur dan daar dicht onder. De overgang van temperatuur vindt dus in een betrekkelijk dunne waterlaag plaats, de ,Sprungschicht”. Belangrijk is ook nog de waarneming der Siboga, dat de Lombok-straat weliswaar de diepste der zeestraten tusschen eilanden der Bali-Ombaai-reeks is, maar volstrekt niet een diepte bereikt, waardoor de scherpe scheiding, door WALLACE ${ }^{\text {I }}$ ) gemaakt, gerechtvaardigd zou worden.

De opneming van het horizontale beeld ${ }^{2}$ ) der Indische zeeën is steeds in handen der Marine geweest; oorspronkelijk door toevallige waarnemingen van zeeofficieren, later door daarvoor speciaal uitgeruste zeilschepen (als eerste in 1858 de schoenerbrik ,Pylades"); nog later werd een stoomschip speciaal voor opnemingen gebouwd (,Hydrograaf", I 874), totdat in het begin van de 20 eeuw het systematische karteeringswerk der Indische zeekusten met kracht werd ter hand genomen, eerst met omgebouwde flottieljevaartuigen later ook met bijzondere „Opnemingsvaartuigen". Aan dit onderzoek hebben vooral deelgenomen H. M. schepen „Bali”, „Borneo”, „Lombok”, „Soembawa”, ,Van Doorn” en „Van Gogh”. Het grootste gedeelte der zeeën van den Indischen Archipel is thans in kaart gebracht, vooral door het werk tusschen I900 en I9IO; dat de vordering thans niet meer zoo vlug gaat, vindt zijn oorzaak in het feit, dat steeds weer het reeds onderzochte herzien moet worden; hoe meer het bekende gebied zich uitbreidt, des te hooger ook zijn de eischen, door de herziening gesteld.

1) Zie p. 163 en 222.

2) J. M. PhafF, r9r3. De hydrographie van den Oost-Indischen Archipel. (Catalogus Kolon. Aardr. Tent. Amsterdam, 20 Sept.-31 Oct. I9r3. p. 40-56). 


\section{HOOFDSTUK XII. \\ Toegepaste natuurwetenschap. \\ Het Proefstationwezen.}

Landbouwpractijk en natuurwetenschap zijn als twee tandraderen van eenzelfde machine; door dezelfde stuwkracht worden ze voortgedreven, steeds grijpen ze in elkaar en helpen elkaar vooruit; wel verwijderen de onderdeelen zich van elkander en trachten ze vaak een tijdlang zelfstandig, zonder met de andere rekening te houden, vooruit te komen, maar na korter of langer tijd drijft de noodzaak hen weer tot elkaar, zoodat ze weer onder wederkeerigen invloed komen.

Zoo is het ook in Indië gegaan. Ontwikkeling van natuuronderzoek doet zich gevoelen ook in landbouwkringen; vooruitgang van den landbouw slaat terug op den naturonderzoeker en prikkelt hem tot nieuwen arbeid. De gestadige uitbreiding van 's Lands Plantentuin, van welke uitbreiding de steeds meer dringende vraagstukken der praktijk grootendeels oorzaak waren, had de reorganisatie tot Departement van Landbouw tengevolge (1905). Maar deze nieuwe stichting en de daaruit voortvloeiende centralisatie van alle natuurwetenschappelijk onderzoek ten behoeve der cultures had haar eigenaardige be- 
zwaren: iedere cultuur stelt bijzondere eischen, vooral wat de ligging van het laboratorium, waar het onderzoek verricht moet worden, betreft. Vandaar dat Treciss porren, om Buitenzorg als centrum van alle proefstations te houden, niet met succes bekroond is; de onderzoekers, belast met bestudeering der Delitabak bijv. waren veel te ver verwijderd van de cultuurlanden en ondervonden hierdoor groote moeilijkheden bij hun werk.

Het is een onmogelijkheid in een beknopt overzicht als dit, alle cultures met hun wetenschappelijke vraagstukken, zelfs maar kort, te bespreken. En bovendien bevindt zich een deel van het proefstationwezen nog dermate in een staat van wording en is de groote ontwikkeling van deze toegepaste natuurwetenschap van nog zoo jongen datum, dat een geschiedenis ervan moeilijk geschreven kan worden. Toch mag aan den anderen kant een uiteenzetting van de voornaamste der problemen niet geheel ontbreken; voor verdere mededeelingen met betrekking tot bevordering van den landbouw door natuurwetenschappelijk onderzoek verwijs ik naar TReub's "Landbouw" ") en naar de in het volgende aangehaalde litteratuur. Het opgeven van de namen der werkers is uit den aard der zaak zeer moeilijk; ik zal mij daarom beperken tot enkele van de meest vooraanstaande onderzoekers, en hoop, dat hierdoor niet de indruk worde gewekt, als zouden slechts weinige mannen hun werkkracht aan deze voor ons Indië zoo uiterst gewichtige taak gegeven hebben en nog altijd geven. Wilde $\mathrm{ik}$ allen vermelden, die in meerdere of mindere mate hieraan meegewerkt hebben, dan zou dit hoofdstuk een adresboek gelijk worden.

ז) M. Treud, igro. „Landbouw”, Januari 1905-October 19ro. Beredeneerd overzicht der verrichtingen en bemoeiingen met het oog op de praktijk van land-, tuin en boschbouw, veeteelt, visscherij en aanverwante aangelegenheden. (Amsterdam, 1910). 
Twee cultures zijn er, die eigenlijk van den aanvang af buiten Buitenzorg om, de hulp van natuuronderzoekers hebben ingeroepen; dit is eenigszins het geval geweest met kina, maar in veel aanzienlijker mate met de suiker.

Het samentreffen van de suikercrisis en van het heftig optreden der zoo schadelijke serehziekte was voor de planters aanleiding, de handen ineen te slaan; samenwerking tusschen de mannen der praktijk, had de oprichting van drie proefstations tengevolge: in I 886 het Proefstation Midden-Java te Semarang en het Proefstation West-Java te Kagok-Tegal, in IS87 volgde het Proefstation Oost-Java te Pasoeroean. Het eerste zou slechts korten tijd blijven bestaan; van Semarang werd het naar Klaten en vandaar naar Bojolali verplaatst en in 1893 , voornamelijk om finantieele redenen opgeheven. In de weinige jaren van zijn bestaan werden "Jaarverslagen" en ,Mededeelingen” gepubliceerd ${ }^{x}$ ).

Een veel gelukkiger leven was beschoren aan de beide andere proefstations West-Java en Oost-Java. Het eerste in I 886 gesticht te Kagok-Tegal, werd I Nov. 1900 als „Proefstation West-Java, Kagok" naar Pekalongan overgebracht; het Proefstation Oost-Java bleef van het begin ( 1887 ) af in Pasoeroean gevestigd. En met ingang van I Jan. I907 werden beide proefstations vereenigd tot "Het Proefstation voor de JavaSuikerindustrie" onder de leiding van een algemeen bestuur. Het station te Pasoeroean werd hervormd tot een cultuurafdeeling, terwijl het station te Pekalongan gereorganiseerd werd, en nu een chemische en een technische afdeeling omvat. De publicaties dier beide proefstations geschiedden cerst

x) Jaarverslag van het Bestuur van het Proefstation Midden-Java, I-VI. (1887-1892). Mededeelingen van het Proefstation Midden-Java 20 stuks. (1890-r893). 
afzonderlijk ${ }^{1}$ ): na I\$93 werden de ,Mededeelingen" opgenomen in het "Archief voor de Java-Suikerindustrie van Ned.-Indie", terwijl na de samensmelting gemeenschappelijke .Jaarverslagen" en "Mededeelingen" verschijnen ${ }^{2}$ ). De kosten der Proefstations worden geheel door bijdragen van de aangresloten suikerfabrieken bestreden, waarbij de contributie berekend wordt naar de grootte van den aanplant, voor I9I 2 per bouw $f$ 2.50. De enorme omvang van het suikerproefstationwezen in Indië blijkt wel uit de finantieele verantwoording der vereeniging, die over 1912 meer dan $f 260.000$ beliep. In 1912 werd de Vereeniging opgenomen in het „Algemeen Syndicaat van Suikerfabrikanten", zoodat het Bestuur van dit Syndicaat thans ook de leiding van het proefstation in handen heeft.

Van het omvangrijk werk, in de 25 jaar van hun bestaan door de suikerproefstations verricht, kan hier uit den aard der zaak slechts het allervoornaamste vermeld worden. Het eerste, wat bij de oprichting te doen viel, was een overzicht te krijgen over de talrijke ziekten van het suikerriet, waarbij vooral de sereh-ziekte een punt van uitvoerig onderzoek geweest is. De

i) Proefstation West-Far'a. Verslag v. h. Proefstation voor suikerriet in WestJava. (I89I-I906).

Bulletin v. h. Proefstation voor suikerriet in West-Java. Kagok, I-VII. ( $\left.1 S_{7}-1889\right)$ en $\mathrm{I}-\mathrm{X}$. (I902-1906).

Mededeelingen v. h. Proefstation voor suikerriet in West-Java. Kagok, I-C. ( $\mathrm{IS} 92$ - I907).

Proefstation Oost-Fava. Mededeelingen v. h. Proefstation voor suikerriet in Oost-Java. (Jaarverslagen hierin opgenomen). $\mathrm{I}^{\mathrm{e}}$ serie $\mathrm{I}-50(\mathrm{I} 887-\mathrm{I} 893), \mathbf{2}^{\mathrm{e}}$ serie $\mathrm{I}-50$ (1893-1898), $3^{\text {e }}$ serie $\mathrm{I}-50$ (1898-1903), $4^{\text {e }}$ serie $\mathrm{x}-39$ (I903-1907).

2) Proefstation zoor de Fava-Suikerindustrie. Jaarverslag van het Proefstation voor de Java-Suikerindustrie 1907-heden (waarin: Verslag der Vereeniging, Verslag der cultuurafdeeling Pasoeroean, Verslag der chemische afdeeling Pekalongan en Verslag der technische afdeeling Pekalongan).

Mededeelingen van het Proefstation voor de Java-Suikerindustrie, I-heden (ro07-heden). 
meest uiteenloopende oorzaken zijn door de verschillende onderzoekers voor deze ziekte aansprakelijk gesteld: sommigen meenden met een aaltjes-(nematoden)-ziekte te maken te hebben : anderen namen bacteriën als ziekteverwekkend agens aan; weer anderen zochten de oorzaak in schimmels, terwijl er ten slotte onderzoekers waren, die de parasitische natuur der ziekte als onbewezen beschouwden, of zelfs haar besmettelijkheid met de meeste beslistheid ontkenden. En in den laatsten tijd is gepoogd, de sereh-ziekte langs geheel anderen weg te verklaren: in 1907 meende een onderzoeker de parasitische en besmettelijke natuur der ziekte eveneens te kunnen ontkennen en de schadelijke gevolgen uitsluitend te kunnen toeschrijven aan zgn. tusschenrasvariabiliteit, een verklaring, die naar alle waarschijnlijkheid onjuist is, terwijl later (I9I I) een ander werker de sereh-ziekte wel degelijk als infectieus beschouwt, en meent in de aantastbaarheid voor sereh-ziekte een aan tusschenras-variabiliteit onderworpen kenmerk te mogen zien. In hoeverre deze laatste opvattingen juist zijn, zal de toekomst ons moeten leeren: in ieder geval is een ziekteverwekkend organisme nog niet met zekerheid bekend.

Over de verdere belangrijke ziekten van het suikerriet, zooals roodrot, roodsnot, ananasziekte, marasmiusziekte, wortelziekten, dongkellanziekte enz., geeft ons een samenvattend overzicht het door WAKKER en WE৯T samengestelde handboek ${ }^{\mathrm{T}}$ ), waarvan het tweede deel, dat de door dieren veroorzaakte ziekten behandelt, door VAN Devexter bewerkt is ${ }^{\circ}$ ).

Behalve dit phytopathologisch werk (J. H. WWKker, I. A.

I) J. H. WAKkER en F. A. F. C. WENT, ISgS. De ziekten van het suikerriet op Java, die niet door dieren veroorzaakt worden. (Leiden, ISgS).

2) IV. VAN I)EVH:NTER, I906. De dierlijke vijanden van het suikerriet en hume parasieten. (Handboek ten dienste van de suikerrietcultuur en de rictsuikerfabricage op Java. II. Amsterdam, I906). 
F. C. WENT, L. Zenntrer) danken wij aan de proefstations anatomische studiën over den bouw van het suikerriet (J. D. Kовts), physiologisch-chemische over suikervorming, suikervervoer en suikerophooping in de planten (WENT); verder bemestingsproeven, waarbij het merkwaardige feit voor den dag kwam, dat kali- en phosphorzuurbemesting in het algemeen geen vergrooting van suikeropbrengst gaf, aangezien het met het irrigatiewater op de sawahs gebrachte vulcanische slib zooveel kali en phosphorzuur bevat, dat deze meestal voldoende zijn voor den rijstoogst, voor de in het volgend jaar gekweekte tweede gewassen en voor het in het derde jaar gekweekte suikerriet, terwijl stikstofbemesting steeds noodig is (H. C. Prinsen Geerligs). Zaaiproeven (F. Soltwedel, Kobus, Wakker) met het oog op selectie van de meest suikerhoudende rietvariëteiten en van sereh-immune rassen, werden veelal met medewerking van practische planters ondernomen en gaven vaak uitstekende resultaten (o. a. het beroemde ras O. J. no. IOO). Verder waren technische problemen op te lossen, sommige van algemeenen aard, andere meer speciaal, zooals het onderzoek der methoden van suikerwinning, teneinde deze zoo voordeelig mogelijk te maken (Prinsen Geerligs). Ook het productief maken van de noodzakelijke onverwerkbare z.g.n. afloopstroop (arakwinning, Prinsen Geerligs en Went) is nog altijd aan de proefstations een punt van onderzoek.

De beide proefstations hebben wel in de eerste jaren van hun bestaan, toen nog pas enkele suikerfabrieken aan de bestrijding der kosten deelnamen, groote moeilijkheden te overwinnen gehad, maar toch werd de door TREub aangeboden hulp, op voorwaarde, dat ze onder den Directeur van 's Lands Plantentuin zouden komen te staan en naar Buitenzorg overgebracht zouden worden, niet aanvaard en wel vooral omdat de laatste bepaling naar de meening der planters, en waar- 
schijnlijk terecht, te bezwarend was. Dat echter ook de suikerplanters voor Treub's werk ten dienste van den landbouw grooten eerbied koesterden, blijkt uit de huldiging, door het Algemeen Syndicaat van Suikerfabrikanten na Treub's aftreden greorganiseerd. En ten slotte zijn de beide overgebleven proefstations bloeiende instellingen geworden; dank zij het aan die inrichtingen verrichte werk is de suikercultuur thans een der meest welvarende, zoodat getuigd kan worden: „Op het oogenblik zouden de suikerindustrieelen zeker niet gaarne hun beide proefstations missen" ${ }^{1}$ ).

Evenals de suikercultuur, heeft ook de Gouvernements-Kinacultuur, buiten 's Lands Plantentuin om, aanraking met en steun bij de natuurwetenschap gezocht ${ }^{2}$ ). De grondvesting en lotgevallen van het wetenschappelijk kina-onderzoek, dat zoo nauw samenhangt met de scheikundige kennis der kinaplant, hebben we grootendeels leeren kennen. Na Ber.elot Moens' vertrek kwam de leiding in handen van P. van Leersum, die als chemicus en als directeur thans reeds 20 jaar de belangen van de Gouvernementskinaonderneming behartigt. Onder zijn leiding is met talrijke onderzoekingen ten behoeve der kinacultuur een aanvang s semaakt; het oude schaduwsysteem werd verlaten; de grondbewerking werd meer en meer verbeterd, waardoor krachtiger wortelontwikkeling en grooter productie van wortelbast bereikt werd; verder nam selectie een belangrijke plaats in, terwijl door enten van de beste soort Cinchona Ledgeriana, die echter zeer sterk aan witte wortelschimmel onderhevig is, op onder-

I) F. A. F. C. WENT, I9rir. p. 24.

2) Bericht omtrent de Gouvernementskinaonderneming. Preangerregentschappen. Tjinjiroean. (Elk kwartaal uitgegeven, extra-bijvoegsel van de JavaBode. 1873-heden).

Jaarverslag van de Gouvernementskinaonderneming. (Thans opgenomen in Jaarb. Dept. v. Landb., Nijverh. en Handel. IS92-heden). 
TOEGEPASTE NATUURIVETENSCHAP.

stammen van de tegen schimmel resistente, maar overigens weinig bruikbare C. succirubra, uitnemende resultaten werden verkregen. De zeer zorgvuldige keuze van entmateriaal heeft in sommige aanplantingen in vier jaar tijds een toename aan kinine-sulfaat-opbrengst van meer dan $60 \%$ ten gevolge gehad. Uit de aanstelling van een botanicus (J. P. Lotsy, 1896-r898), vooral belast met de bestudeering van de physiologische beteekenis der scheikundige kinabestanddeelen, is later (I9I I) een speciaal kina-proefstation te Tjinjiroean voortgekomen ${ }^{x}$ ). De voornaamste punten van onderzoek betreffende de kinacultuur zijn behalve de selectie van die kinaboomen, wier schors het hoogste gehalte aan kinine bevat, de localisatie dier kina alcaloiden en hun beteekenis voor het leven der plant, de verschillende ziekten, waaraan kina-aanplantingen onderhevig zijn, de oorzaken dezer ziekten: schimmels en insekten en hun bestrijding.

Het verband tusschen Plantentuin, later Departement van Landbouw, en de andere groote cultures was veel nauwer. Als belangrijkste hiervan zijn te noemen getah-pertjah en caoutchouc, koffie, tabak, thee en inlandsche landbouwproducten, voornamelijk rijst.

De door BuRck in 1882 ondernomen reis naar de Padangsche Bovenlanden ${ }^{2}$ ) had tot doel de bestudeering der voornaamste getah-pertjah-leverende boomsoorten; immers het was uit een door TReuB bijeengebrachte verzameling van monsters en herbariummateriaal uit den geheelen Archipel gebleken, dat zich onder deze stof leverende boomsoorten zeer uiteenloopende typen bevonden en dat een nauwkeurige systematische studie dezer planten van het hoogste belang was. De arbeid

1) Mededeelingen van het Kina-Proefstation te Tjinjiroean. (I-.., I912 heden).

2) Zie boven p. 202. 
van BurCk en Boerlage bracht uitkomst uit de verwarring, die op dit gebied heerschte; vooral van beteekenis bleek de soort Palaquium oblongifolium Brck. te zijn, terwijl enkele andere Palaquium- en Payena-soorten getah-pertjah van minder goede hoedanigheid leverden. Maar ook bleek, dat de inlanders de getah-pertjah op zeer onoordeelkundige wijze wonnen, dat ze zeer roekeloos met het leven dezer kostbare boomen omsprongen, zoodat volwassen exemplaren zeldzaam geworden waren. Ingrijpen van gouvernementswege was dus een dringende eisch, indien men de dreigende uitroeiing voorkomen wilde. Wel waren reeds (ongeveer 1856) in enkele residenties proeven genomen met den aanplant van getah-pertjah-boomen, waarvan die in Banjoemas het meeste resultaat had, maar geen van deze ondernemingen slaagde erin, een bloeiend bestaan te verwerven; de een na de ander werd opgeheven.

De bemoeiïgen van Treub en Burck hadden tot resultaat, dat een proefaanplanting werd aangelegd in Tjipetir (nabij Tjibadak in de Preanger Regentschappen, 1885), welke aa! planting langzamerhand vergroot werd en in 1900 een belangrijke uitbreiding $\mathrm{kreeg}^{\mathrm{r}}$ ). De cultuur omvat thans voornamelijk boomen der soort Palaquium oblongifolium Brck; moeilijkheden worden niet meer ondervonden, terwijl de aanplantingen bijna niet van ziekten te lijden hebben (de ergste vijand is een bladrollerrups). Alle onderzoekingen kunnen dus gericht zijn op de bereidingswijze cler getah-pertjah, die tegenwoordig niet meer alleen door insnijdingen in de stammen gewonnen wordt, maar ook uit de blaren bereid wordt. Deze laatste bereidingswijze neemt steeds meer in beteekenis toe. Bij de definitieve oprichting van de Gouvernements getah-pertjah onderneming in I 900 bleef de leiding berusten bij den chef van het agricultuurchemisch laboratorium te Buiten-

1) Zie versliagen in Jaarboek Dept. v. Landb., Nijverh. en Handel. 
zorg; na 1910 werden beide instellingen gescheiden, en kreeg ieder een eigen directeur.

Caoutchouc wordt door een groot aantal plantensoorten geleverd; daarvan is in onze koloniën inheemsch Ficus elastica, waarvan ongeveer 1870 de eerste aanplant in Krawang werd aangelegd, spoedig door andere gevolgd. Ook de Braziliaansche boomsoort Hevea brasiliensis werd, na de gunstige ervaringen in Engelsch-Indië hiermede opgedaan, door bemiddeling van Buitenzorg's Plantentuin op Java en Sumatra ingevoerd, met het gevolg, dat thans in onzen Archipel groote plantages van Hevea-boomen aangetroffen worden. Een derde caoutchoucleverende plant, Castilloa elastica, inheemsch in Mexico en: Centraal-Amerika, heeft eveneens langs Buitenzorg haar intocht in Indië gehouden; echter is deze intocht niet in die mate een zegetocht geworden, als dit met Hevea het geval was. De in I907 te Langsa (Atjeh) opgerichte Gouvernements-caoutchouconderneming begint thans de eerste moeilijkheden van haar bestaan te overwinnen. Zoo hebben getah-pertjah- en caoutchoucondernemingen aan den Plantentuin en de daar werkzame ambtenaren veel te danken.

De eerste aanraking tusschen de koffiecultuur en de natuurwetenschap, vertegenwoordigd door 's Lands Plantentuin had plaats toen in IS85 op Java de schimmel van de koffiebladziekte, Hemileia vastatrix, haar schadelijken invloed gelden liet. De toenmalige adjunct-directeur van 's Lands Plantentuin, Dr. W. Burck, stelde een onderzoek in naar de levenswijze en de bestrijdingsmogelijkheid van deze parasitische schimmelsoort. Later (1892) werd het verband tusschen de reeds lang bestaande Gouvernements-koffieonderneming en de natuurwetenschap nauwer, door de aanstelling van Burck tot wetenschappelijk adviseur voor de koffiecultuur. En in $1896 \mathrm{kwam}$ door samenwerking van 's Lands Plantentuin en een vereeniging van 
koffieplanters een "Proefstation voor koffie" tot stand, dat oorspronkelijk geheel door particulieren betaald werd, maar in I90 I werd omgezet in een "Laboratorium voor Gouvernementskoffiecultuur" ") met daaraan verbonden proeftuin. Het laboratorium werd in I9I I opgeheven, terwijl de proeftuin voorloopig nog behouden bleef.

Het scheikundige werk, aan dit Laboratorium verricht, betrof in de eerste plaats bodemonderzoek in den meest uitgebreiden zin : bodemanalyse en bodemverbetering door bemesting; verder een onderzoek naar de verschillende bestanddeelen der koffiezaden, waarbij belangrijke uitkomsten verkregen werden, о. a. wat betreft de beteekenis der zoogenoemde koffielooizuren, zooals chlorogeenzuur, voor de kleur der koffie, een voor de praktijk zeer belangrijk vraagstuk. Van chemisch-bacteriologische natuur was de studie van het fermentatie-proces, waarbij gevonden werd, dat een melkzuurgisting de belangrijkste rol speelde. Phytopathologisch werk had de verschillende koffieziekten als studievoorwerp: aaltjesziekten, veroorzaakt door talrijke soorten parasitische Nematoden, schimmelziekten, waaronder de koffiebladziekte en de zgn. djamoer oepas e. a. Daarnaast zuiver botanisch werk, als variabiliteitsstudiën en het onderzoek van de biologie der koffiebloem. De variabiliteit der voorhanden koffiesoorten werd onderzocht, teneinde door selectie uit de aanwezige vormen de beste te kunnen kiezen voor vermenigvuldiging; daarnaast werden talrijke nieuwe soorten uit Afrika ingevoerd, om door systematische kruisings- en selectieproeven te trachten de koffieaanplantingen te verbeteren, o. a. rassen te isoleeren met een groot weerstandsvermogen tegen de koffiebladziekte. Het onderzoek van de biologie der koffiebloem,

${ }^{x}$ ) De publicaties van het Koffie-Proefstation verschenen grootendeels in "Mededeelingen en Bulletins" van Buitenzorg; deels ook in Teysmannia en Ann. d. Jard. Bat. Buitenzorg. 
zoowel bij de oorspronkelijk gekweekte Java- en Liberiakoffie, als bij later ingevoerde soorten (robusta-achtige soorten als Coffea robusta, C. Ugandae, C. canephora) bracht belangrijke waarnemingen, o. a. over de natuur der ,sterretjes" en over de bestuivingsbiologie. De herleving van de koffiecultuur op Java in de laatste jaren is ongetwijfeld voor een groot deel aan den arbeid van dit proefstation te danken.

Hoezeer sommige mannen der practijk het werk van TREUI en zijn staf naar waarde wisten te schatten, bleek ook in 1893 , toen de Deli-planters, daartoe gedreven door het meer en meer epidemisch optreden der bibit-ziekte in de jonge tabak, aan TRELB een belangrijke som aanboden ten einde daaruit de kosten te bestrijden voor aanstelling van een plantkundige, die te Buitenzorg verblijf houdende, zich uitsluitend met onderzoek der Deli-tabak, haar eigenschappen en haar ziekten, zou bezighouden; maar nog meer gaven ze TREUb een bewijs van hun vertrouwen door van alle verdere bemoeiing met het onderzoek af te zien; zij wisten, dat de leiding van dit uitsluitend op de practijk gerichte onderzoek bij hem in goede handen was. In I 995 kwam hieruit voort de stichting van een Laboratorium ${ }^{\mathrm{x}}$ ) voor onderzoek der Deli-tabak als afdeeling van den Plantentuin, na 1905 van het Departement van Landbouw. Uit den aard der zaak was het noodig, dat het technisch personeel een groot deel van het jaar te midden der tabaksvelden in Deli doorbracht, een omstandigheid, die op den duur zoo bezwaarlijk werd, dat het geheele Proefstation naar Medan (Deli) werd overgebracht (1906) en thans daar vrijwel alle verband met den Plantentuin mist ${ }^{2}$ ). Ook hier waren het in de eerste plaats

r) De publicaties werden opgenomen in de door 's Lands Plantentuin uitgegeven Mededeelingen en Bulletins.

2) Thans rerschijnen: Mededeelingen van het Deli-Proefstation te Medan. I-... (rgo7-heden).

Bulletin ran het Deli-Proefstation te Medan. I-... (rgr4-heden). 
phytopathologische vraagstukken, die de aandacht der onderzoekers vroegen: de bibitziekte, die door Dr. J. V. BREDA INE: HAAN terecht als een schimmelziekte (Phytophtora Nicotianae) herkend werd en sedert afdoende kon worden bestreden; verder aaltjesziekte, slijmziekte en de raadselachtige mozaiekziekte, welke laatste ondanks de tallooze hierover verrichte onderzoekingen, nog steeds niet begrepen wordt. Behalve het onderzoek en de bestrijding dezer ziekte is ook het tegengaan van schadelijke rupsen en bladluizen met behulp van de Amerikaansche methode, nl. door middel van op deze dieren parasiteerende insekten, (Dr. L. P. LE Cosǫtino DE Bussy) nog steeds een belangrijk punt van studie, dat naast de gewone bestrijdingsmiddelen (Parijsch groen, loodarsenaat) van groote practische beteekenis belooft te worden. De voornaamste scheikundige onderzoekingen, o.a. door Dr. A. vis Bijlert en Dr. D. J. Hissisk verricht, hadden betrekking op de volgende onderwerpen: grondonderzoek, bemesting, practische behandeling van de geoogste tabak, vooral met het oog op de brandbaarheid, tegenwoordig ook het proces der fermentatie, enz.

Het tweede centrum van tabakscultuur, de Vorstenlanden op Java, riep in 1896 de hulp der wetenschap in: in dat jaar werd een botanicus aan den Plantentuin aangesteld, belast met cle bestudeering der vraagstukken, die op Vorstenlandencultuur betrekking hebben; in $1 S 9 s$ een tweede plantkundige. I Het in Buitenzorg opgerichte Proefstation voor Tabak ${ }^{\text {) }}$ der Vorstenlanden werd uitgebreid en terwijl het een afdeeling van het Departement bleef, naar Klaten verplaatst, waar het na I Nov.

I) $\mathrm{Na}$ de verspreide publicaties in de uitgaven van lututenzors, begonnen in InI te verschijnen: Mededeelingen van het Proefstation voor 'Tabak. I-VII. (ig1I-1912), thans:

Mededeelingen van het l'rocfstation voor Forstenlandsche 'Talak. I-... (19r3-heden). 
I9I 2 vereenigd werd met het inmiddels aldaar door particulieren opgerichte Proefstation voor Vorstenlandsche Tabak. Het behartigt thans uitsluitend de belangen der tabaksondernemingen, die in de residenties Soerakarta en Djocjakarta gevestigd zijn. De onderzoekingen over Vorstenlandsche Tabak liepen uit den aard der zaak voor een deel evenwijdig met die van het Deli-proefstation: ziekten en bemestingsvraagstukken werden hier eveneens met uitnemende resultaten bestudeerd. Maar daar naast werden in Klaten belangrijke selectie- en kruisingsproeven verricht (Dr. J. A. LodewiJks, Dr. HJ. Jensen); de nieuwe richting op het gebied van erfelijkheids- en bastaardeeringsonderzoek had ook hier haar invloed doen gelden; bijna alle tabaksondernemingen werken thans met zuivere rassen, die oorspronkelijk door het Proefstation gekweekt zijn ${ }^{2}$ ).

Ten behoeve der theecultuur was reeds in IS94 een scheikundig assistent aan 's Lands Plantentuin werkzaam gesteld; nadat in 1903 voor dit onderzoek, hetwelk totnogtoe in het agricultuurchemisch laboratorium verricht werd, een afzonderlijke afdeeling aan den Plantentuin was in het leven geroepen, werd in 1907 tusschen den Directeur van den Landbouw en de Soekaboemische Landbouwvereeniging een overeenkomst aangegaan, volgens welke een volledig "Proefstation voor thee" zou worden opgericht voor rekening dier vereeniging. De talrijke vraagstukken, die de theecultuur opleverde, vinden door de studie aan dit proefstation langzamerhand hun beantwoording ${ }^{2}$ ); de arbeid der hier werkende onderzoekers gold naast vragen van zuiver-chemischen aard (Dr. A. W. Nanninga), vooral de

ז) Een overzicht van het tot I9I3 verrichte werk in: Meded, v. h. Proefst. v. Vorstenl. Tabak. V. (1913).

2) Ook van dit Proefstation verschijnen na rgo8 eigen publicaties:

Mededeelingen van het Proefstation voor Thee. I-... (1908-heden). 
problemen der selectie en gewasverbetering der bestrijding van verschillende theeziekten, vooral van die door de ,red-spider" en de ,oranje-mijt" veroorzaakt worden (BERNARI), der fermentatie met de mogelijke beteekenis van gistsoorten voor den goeden gang van dit proces, enz.

In 1892 werd door de Klatensche Cultuurmaatschappij, na de opheffing van het suikerproefstation Midden-Java, opgericht het proefstation te Klaten, waar onderzoekingen verricht zouden worden over cultuur en bereiding van indigo, tabak en suiker. Na I 896 legde dit proefstation zich vooral op suikerstudie toe, terwijl daarnaast door eenige Indigo-ondernemingen een speciaal Indigo-proefstation werd opgericht. De voornaamste arbeid betrof ○. a. het procédé ter bereiding van Natal-indigo, hetwelk van groote beteekenis geworden is. De achteruitgang der indigoteelt na de bereiding van synthetische indigo was ondanks het werk der proefstations niet tegen te gaan; dientengevolge is het Indigo-proefstation opgeheven.

Het in I90 r te Salatiga opgerichte Proefstation voor Cacao (Dr. L. Zehntser) bleef bestaan tot 1904 en publiceerde in dien tijd verschillende "Korte Mededeelingen" en „Berichten”; na I Januari I 905 werd het gereorganiseerd tot „Algemeen Proefstation" te Salatiga. De grootsche ontwikkeling, die door dit Algemeen Proefstation in korten tijd bereikt werd, zou slechts van korten duur zijn; in I9I I werd de organisatie als zoodanig opgeheven en vervangen door verschillende kleinere proefstations, die grooten deels het werk voortzetten van de tot het Algemeen Proefstation behoorende hulpproefstations te Bandoeng (Kina en Caoutchouc), te Klaten (Vorstenlandsche Tabak), te Salatiga (Cacao) en te Malang (Koffie). Een lange rij van onderzoekers was gedurende korter of langer tijd aan dit Algemeen Proefstation werkzaam; van de lotgevallen en de hoeveelheid werk, hier verricht geven de vier jaarverslagen (1906-1909) een uit- 
voerig overzicht ${ }^{\mathrm{I}}$ ). Bij de opheffing werd het hulpproefstation Bandoeng als Kina-proefstation bij de Gouvernements-Kinaonderneming ingedeeld en naar Tjinjiroean overgebracht; het hulpproefstation Klaten werd Proefstation voor Vorstenlandsche Tabak en als zoodanig vereenigd met het uit Buitenzorg af komstige Proefstation voor Tabak.

In de maand December I9Io werd door invloed van den nieuwen Directeur van Landbouw, Treub's opvolger H. J. Lovink, een drietal vereenigingen opgericht met het doel speciale proefstations te stichten en te onderhouden. De drie nieuwe proefstations kwamen tot stand door de hulp van een groot aantal cultuurondernemingen, werden gevestigd te Djember, te Salatiga en te Malang, en blijven in voortdurende samenwerking met het Departement van Landbouw.

Het „Besoekisch Proefstation" te Djember ${ }^{2}$ ), tot welks stichting besloten werd op de algemeene vergadering van de Vereeniging ter bevordering van Landbouw en Nijverheid, gehouden Io December I9IO, vond een krachtigen steun in den Besoekischen tabaksplanter D. Birnie. In de eerste plaats betreffen de onderzoekingen natuurlijk de verschillende problemen der tabakscultuur; daarnaast werden ook vraagstukken betreffende rubber- en koffiecultuur ter hand genomen.

Het Proefstation Midden-Java, dat als voortzetting van het hulpproefstation voor Cacao te Salatiga gevestigd bleef ${ }^{3}$ ) werd

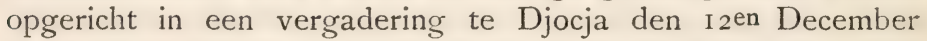
I9IO en in het begin vanuit Buitenzorg geleid door den chef

r) Verslag omtrent den staat van het Algemeen Proefstation te Salatiga. (1906. 100 pp.; 1907, I76 pp.; 1908, 391 pp. en 1909, 4I 1 pp.). Verdere publicaties: Mededeelingen van het Algemeen Proefstation Salatiga. Ie serie. $N^{\circ}$. I - IS. ( = Bulletin $\mathrm{N}^{\circ}$. $\mathrm{I}-5$ en Korte Mededeelingen $\mathrm{N}^{\circ}$. $\mathrm{I}-\mathrm{I} 3$ ), $\mathrm{II}^{\mathrm{e}}$ serie $\mathrm{N}^{\circ}$. $\mathrm{I}-49$ en III serie $\mathrm{N}^{\circ}$. I -6 .

2) Mededeelingen van het Besoekisch Proefstation. I-... (1912-heden). Mededeelingen van het Proefstation Midden-Java. I-... (I9r I-heden ) 
van de Afdeeling voor Plantenziekten, behoorend tot het Departement van Landbouw. De groote bezwaren, uit deze dubbele functie voortvloeiende, waren oorzaak, dat DR. vaN HaLl deze directe leiding moest opgeven en in I 913 vervangen werd door een afzonderlijken directeur. De leiding van de selectie- en teeltproeven bleef in handen van Dr. vis Hal. berusten, terwijl de directeur als entomoloog de richting der overige onderzoekingen aangaf. De voornaamste onderzoekingen hadden betrekking op de levenswijs van het cacaomotje, op het voorkomen van boorders in cacao, op selectie van cacao en robusta-koffie en op cacaokanker.

Het derde van deze proefstations, het Proefstation Malang ${ }^{-}$) zet voor een gedeelte het werk van het opgeheven Koffieproefstation van Buitenzorg voort, voor een deel ook het werk van het hulpproefstation voor koffie te Malang, dat van het Algemeen Proefstation deel uitmaakte. De hier verrichte onderzoekingen betreffen in de eerste plaats de koffiecultuur en wel voornamelijk de ziekten en dierlijke vijanden, daarnaast worden vraagstukken over rubbercultuur behandeld.

Reeds zagen wij, dat na de omzetting van 's Lands Plantentuin in Departement van Landbouw de toegepaste wetenschappen steeds meer de overhand gekregen hadden, en dat na Trfuri's vertrek de Plantentuin weer als afzonderlijke instelling herboren werd. Tot dezen Plantentuin, die onder leiding staat van Dr. J. C. Koningisberger, behooren thans het herbarium en museum voor systematische botanie (chef Dr. J. J. Sirmir), de botanische laboratoria (chef Dr. F. C. rox li.ABER), het zoülologisch museum en laboratorium (chef Dr. J. C. KonINGsiekcier) en het pharmacologisch laboratorium (chef Dr. W. G. Bonssmi). Naast deze zuiver natuurwetenschappelijke inrichtingen, waar indien dit noodig is, ook weleens werk ten behoeve der practijk

i) Mededeelingen van het Proefstation Malung I-... (rgıI-heden). 
verricht wordt, omvat het Departement van Landbouw thans o. a. de volgende technisch-natuurwetenschappelijke afdeelingen: Afdeeling voor Plantenziekten (chef Dr. C. J. J. van HALL ${ }^{x}$ ), waar belangrijke mycologische en entomologische onderzoekingen geschieden, zoowel ten behoeve der groote cultures als voor den inlandschen landbouw (rijst, katoen, enz.,) Afdeeling Veredeling van Cultuurgewassen (chef Dr. P J. S. CRAMER), die als werkdoel heeft de selectie en gewasverbetering van alle overblijvende planten der groote cultures, Afdeeling Selectie en Zaadtuinen voor rijst en tweede gewassen (chef J. E. v. D. STOK), waar de veredeling van de planten voor inlandschen landbouw op den voorgrond staat, voortgekomen uit het Proefstation voor rijst en tweede gewassen ${ }^{2}$ ), Afdeeling Agricultuur-chemisch Laboratorium (chef Dr. A. W. K. DE JoxG) ${ }^{3}$ ), waar vooral bemestingsproeven voor den inlandschen landbouw gedaan worden; Afdeeling Agrogeologisch Laboratorium (chef Dr. E. C. J. MoHR), dat vooral geologische onderzoekingen ten behoeve van den landbouw verricht en de Afdeeling Laboratorium voor rubberonderzoek (chef Dr. K. Gorter) ${ }^{4}$ ), waar de chemie van de rubber hoofdpunt van studie is.

De schijnbare decentralisatie van het natuurwetenschappelijk onderzoek ten behoeve der cultures, waarin TREuB een zóó groot gevaar had gezien, dat hij trachtte, alle onderzoekingen te Buitenzorg te doen geschieden, blijkt thans van niet zoo nadeelige gevolgen te zijn. Drie factoren zijn aan te wijzen, waardoor de bezwaren der specialisatie van het proefstation-

I) Mededeelingen van de Afdeeling voor Plantenziekten v. h. Depart. v. Landb., Nijv. en Handel. I-... (r912-heden).

2) Mededeelingen van het Proefstation voor rijst en tweede gewassen. I-... (1912-heden).

3) Mededeelingen van het Agricultuurchemisch Laboratorium. I-... (rgrz-heden).

4) Mededeelingen over Rubber. (Dept. v. Landb., Nijv. en Handel). I-... (1911-heden). 
wezen ondervangen worden, en waardoor arbeidsverspilling wordt tegengegaan : ten eerste het steeds gemakkelijker wordend algemeen verkeer, dat de samenwerking der proefstations met Buitenzorg belangrijk bevordert; ten tweede het uitwisselen der publicaties, waardoor niet alleen de onderzoekers zelf, maar ook het personeel der aangesloten cultuurondernemingen op de hoogte blijven van wat er aan andere proefstations ten bate van een bepaalde cultuur verricht wordt, en ten derde de jaarlijksche bijeenkomsten der aan de verschillende proefstations en aan de ,,technische" afdeelingen van Buitenzorg werkzame onderzoekers, waardoor niet alleen bespreking der verschillende problemen, maar ook eenheid in werkprogramma's bereikt kan worden.

Behalve de toegepaste natuurwetenschappen, die aan de proefstations vertegenwoordigd worden, voornamelijk plantkunde en scheikunde, maar ook entomologie, vinden andere richtingen van natuuronderzoek in onze koloniën evenzeer practische resultaten; zoölogie staat in dienst van de visscherij, zoodat naast het Buitenzorgsche laboratorium en museum thans een visscherijstation te Batavia is gevestigd ${ }^{2}$ ); geologie en palaeontologie vinden hun toepassing in het mijnwezen, van welks ontwikkeling het omvangrijke ,Jaarboek voor het Mijnwezen ${ }^{2}$ ) een schitterend getuigenis aflegt; meteorologie bewijst ook, vooral door de regenwaarnemingen ${ }^{3}$ ) en wellicht in de toekomst ook door juiste weervoorspellingen goede diensten aan den landbouw.

De wisselwerking tusschen natuurwetenschap en practijk is van tweeërlei gevolg geweest: voor de wetenschap verjongend en verlevendigend was het verband met landbouw en techniek, voor de practijk was de steun der theoretische onderzoekers van groote economische beteekenis; beide voor elkaar onmisbaar.

ז) Mededeelingen van het Visscherij-Station te Batavia. I- ... (rgo\&-heden).

2) Jaarboek van het Mijnwezen in Ned. Oost-Indië. I- ... ( $1872-$ heden).

3) Regenwaarnemingen in Ned.-Indië. I-... ( 1879 -heden). 


\section{HOOFDSTUK XIII. \\ De West-Indische bezittingen.}

Suriname en Curaçao zijn voor ons land altijd min of meer stief kinderen geweest; de zooveel rijkere Oost-Indische Archipel trok teveel de aandacht der Nederlanders, zoodat de WestIndische koloniën maar al te vaak als nietbestaande beschouwd werden. En in de oogen van het groote publiek is dit grootendeels nog zoo: Indië ligt in Azië; zelfs zou ik het nog sterker willen uitdrukken: als Indië wordt slechts één eiland beschouwd, Java. Dat wij behalve Java nog Buitenbezittingen en nog WestIndische koloniën hebben, wordt te vaak vergeten, terwijl toch juist die Buitenbezittingen van steeds meer belang blijken te zijn. Niet ten onrechte sprak VAN EEDEN in 1896 nog van een „,verwaarloosd erfdeel" ${ }^{x}$ ). Hierin is in de laatste jaren een verandering ten goede gekomen; het ontwaakte zelf bewustzijn van Nederland als koloniseerende mogendheid heeft ook hier zich laten gelden en de beteekenis van het onderzoek der WestIndische bezittingen ten volle begrepen.

"Nederland heeft zijn plicht als beschaafde natie vergeten";

I) F. W. van Eeden, 1896. Een verwaarloosd erfdeel. (Bull. Kol. Mus, 12 Maart 1896. p. I-I3). 
V.x EErex had volkomen gelijk, toen hij dit opmerkte, maar thans is het zich van dezen plicht bewust geworden en heeft in het sedert verloopen tijdvak van nog geen tivintig jaar getoond, wat het wilde en wat het kon. Er is nog lang niet genoeg verricht om thans reeds met een gevoel van zelfvoldaanheid te gaan terugzien op al dat mooie werk en te gaan denken, dat wij ons nu toch al heel verdienstelijk gemaakt hebben; wij staan aan het begin van een lange en moeilijke weg, waarop de eerste schreden gezet zijn, waarvan de eindpaal nog niet te zien is, maar die ten slotte leiden mòet tot de welvaart van West-Indisch-Nederland.

Een geschiedenis te schrijven van zoo recent werk is niet mogelijk, een overzicht geven van wat er gedaan is, misschien wel en daarom moge in dit laatste hoofdstuk datgene vermelding vinden, wat bewijzen kan, dat Nederland thans ook het natuuronderzoek van de IVest als een roeping beschouwt.

Wel is er in de eerste helft van de negentiende eeuw belangrijk algemeen-natuurwetenschappelijk verzamelwerk verricht door A. Kappler (1816-1887), een Stuttgarter van geboorte, die door zijn lust voor avonturen zich in $18_{35}$ te Harderwijk liet aanwerven voor het koloniale leger en voor Suriname bestemd werd. Na zes jaren bij het leger gediend te hebben, nam hij in I $\$+2$ ontslag om met handel en kolonisatie in zijn onderhoud te voorzien, en maakte na dien tijd gedurende zijn verder verblijf in Suriname (tot 1879) talrijke reizen naar het binnenland, vanwaar hij groote verzamelingen van zoölogische en botanische voorwerpen meebracht. Dat KAPPLER een goed waarnemer geweest is, blijkt wel uit de floristische en faunistische beschrijvingen, die hij ons in zijn boek ,Surinam" ${ }^{2}$ ) gegeven heeft.

1) A. KAP'LER, rSS7. Surinam, sein Land, seine Natur, levölkerung etc. (Stuttart, $\mathrm{rSS}_{i} \cdot 3^{S}+$ pp.). Hierin: Die Ptlanzenwelt. p. $15-45$ en Die Tierwelt. p. $4^{6}-205$. 
DE IVEST-INDISCHE BEZITTINGEN.

Nederland had vóór I $\$ 96$ reeds een expeditie zien uitrusten naar Suriname en Curaçao: de Nederlandsche hoogleeraren Dr. K. Martix en Dr. W. F. R. Surivgar vergezeld door den geoloog G. A. F. MolengranfF, den entomoloogJ. R. H. Neervookt VAN DE POLL en den botanicus J. van BREDA DE HAAN vertrokken in December 1884 naar de West, waar eerst gemeenschappelijk Curaçao bezocht werd, evenals Aruba en Bonaire. Martin en Neervoort van de Poll vertrokken daarop samen naar Suriname (April isS5), terwijl Suringar met Molengraaff en DE HaAn de ,eilanden boven de wind" als onderzoekingsveld kozen. Algemeene reisbeschrijvingen verschenen van MARTIN ${ }^{\mathrm{I}}$ ) en van SURINGAR ${ }^{2}$ ); de bewerking der geologische resultaten werd door Martin en Molenr.aAF bezorgd ${ }^{3}$ ), der zoölogische door het personeel van het Leidsche Museum van Natuurlijke Historie ${ }^{4}$, der botanische door SURINGaR ${ }^{5}$ ).

Evenals dit met het nog weinig bezochte Nieuw-Guinea het geval was, zoo herleefde in het begin dezer eeuw ook de lust tot onderzoek van Suriname's achterland.

ェ) K. Martin, 1885. Reisbeschrijving. ('Tijdschr. K. N. A. G. $2^{\text {e }}$ serie II. p. $337-36 \mathrm{r}, 448-487$ en 6 ro-646).

K. Martin, i886. Bericht über eine Reise ins Gebiet des oberen Surinam.

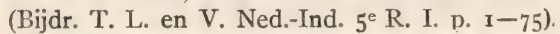

K. Martin, I888. Bericht über eine Reise nach Niederländisch West-Indien und daraufgegründete Studien. I. Land und Leute. II. Geologie. (Leiden, ISSS. I. I 86 pp., II 238 pp.).

2) W. F. R. Suringar, I886. Nederlandsch-West-Indische Expeditie. Verslag en Reisverhaal. (Tijdschr. K. N. A. G. $2^{\text {e }}$ serie III. p. 45-90, 355-394 en 5 I I -545 ).

3) K. Martin, I888. t. a. p. deel II.

G. A. F. MolengraffF, i886. De geologie van het eiland St. Eustatius. (Leiden, I886. $4^{\circ} .62 \mathrm{pp}$.).

4) In de "Notes from the Leyden Museum" VIII en vv. en Tijdschr. v. Entomologie. XXX.

5) In „Verslagen” en „Verhandelingen”. Kon. Ak. v. Wet. Amsterdam Afd. Natuurkunde. De bewerking werd later door Dr. J. VAlckenier Suringar voortgezet. 
De belangrijke geologische uitkomsten, die Martin en de Commissaris van het district Nickerie, C. van Drimmelen, op hun reizen verkregen hadden, waren voor Dr. $H$ vaN Cappelle: aanleiding, het plan tot een onderzoekingstocht naar Suriname te ontwerpen. Krachtige steun werd hem hierbij verleend door F. W. van Eeden, terwijl de Regeering een opwekkend voorbeeld gaf, door een belangrijk subsidie toe te staan, een voorbeeld door velen gevolgd. Vergezeld door Van Drimmelen en den pharmaceut Dr. J. E. Tulleken, reisde Van Cappelle ${ }^{\mathrm{I}}$ ) den $27^{\text {sten }}$ Augustus I 900 van Paramaribo af langs de Nickerie, voornamelijk om het terrein tusschen Nickerie- en Coppenamerivier te exploreeren, in het bijzonder de Fallawatra. De tocht, die ruim twee maanden duurde, werd met succes volbracht. Het zoölogische materiaal werd in het Leidsche Museum van Natuurlijke Historie bewerkt; de botanische verzamelingen bevinden zich in 's Rijks Herbarium; de geologische waarnemingen publiceerde VAN CAPPELLE zelf ${ }^{2}$ ).

In den loop van 1897 was in de „Vereeniging voor Suriname" de wenschelijkheid van een systematisch wetenschappelijk onderzoek van de totnogtoe weinig bekende streken van Suriname ter sprake gekomen, met het gevolg, dat door samenwerking van de Maatschappij t. bev. v. h. Nat. Onderzoek der Nederl. Koloniën (Treub-Maatschappij), het Koninklijk Aardrijkskundig Genootschap en de Vereeniging voor Suriname een "Commissie ter voorbereiding en uitrusting eener wetenschappelijke expeditie naar Suriname" werd ingesteld, die onder het genot van een belangrijk regeeringssubsidie erin slaagde, een onderzoekingstocht (Juli-December I90 I) te organiseeren, waar-

s) H. van Cappelle, I908. De Binnenlanden van het district Nickerie. (Baarn, 1903. 241 pp.).

2) H. van Cappelle en E. H. M. Beekman, 1907. Essai sur la constitution géologique de la Guyana hollandaise. (District occidental) suivi d'une étude pétrographique. (Baarn-Paris, 1907. $182 \mathrm{pp}$.). 
van de leiding werd opgedragen aan den oud-majoor L. A. Baknlis, met den luit. t. zee re $\mathrm{kl}$. A. J. van Stockun, den off. v. gez. $2 \mathrm{e} \mathrm{kl}$. M. A. Boov en den gouvernementslandmeter W. L. Loth als deelnemers. Het geographisch onderzoek stond natuurlijk bij deze en bij alle volgende Suriname-expedities op den voorgrond; zoölogisch en botanisch materiaal werd verzameld door den oft. v. gez. M. A. Boon, een geologische collectie werd aangelegd door den landmeter Lotu. Het reisverhaal van deze eerste Suriname-tocht, bekend als de Coppenameexpeditie werd door den leider in het Tijdschr. K. N. A. G. gregeven ${ }^{\mathrm{T}}$ ). De zoölogica werden aan 's Rijks Museum v. Nat. Hist. ter bewerking afgestaan; de botanische voorwerpen aan het Botanisch Laboratorium te Utrecht, en de gesteenten aan 's Rijks Geologisch-Mineralogisch Museum te Leiden.

Een tweede expeditie, de Saramacca-expeditie ${ }^{2}$ ), werd in November 1902 ondernomen (tot Mei 1903) door luit. t. z. A. J. van Stockum als leider, met drs. A. A. Pulle als botanicus en arts P. J. DE Kock als zoölogisch verzamelaar. Daarna volgden nog vijf Suriname-onderzoekingstochten en wel achtereenvolgens:

De Gonini-expeditie (Juli 1903-Januari $1904{ }^{3}$ ), onder leiding van $\mathrm{i}$ luit. A. Franssen Herderschee; deelnemers waren luit. t. zee ze kl. C. H. DE Goeje, semi-arts G. M. Versteeg (voor

I) L. A. Bakhuis, 1902. Verslag der Coppename-expeditie. Met astronomische plaatsbepalingen door A. J. vas Stockum en een lijst van gedetermineerde gesteenten door Dr. G. A. F. Molengraaff. (Tijdschr. K. N. A. G. $\mathbf{2}^{\mathrm{e}}$ serie XIX. p. $695-852)$.

$\Rightarrow$ A. J. vax Stockun, igo4. Verslag van de Saramacca-expeditie. Met een verslag van het voorloopig onderzoek der gesteentemonsters door C. MoERMAN. (Tijdschr. K. N. A. G. $2^{\text {e }}$ serie XXI. p. 88-J22, 227-310, 65I-721, S22-S7S, 1022-1069).

3) A. Franssex Herderschee, 1905. Verslag van de Gonini-expeditie. Met een verslag van astronomische plaatsbepalingen door C. H. DE GoEJE en een verslag omtrent de meegebrachte afdrukken van ornamenten door L. C. rAN Panhuys. (Tijdschr. K. N. A. G. $z^{e}$ serie XXII. p. $1-74$ ). 
botanische en zoölogische verzamelingen) en districts-commissaris H. VAN BREEN.

De Tapanahoni-expeditie (Juni-November $1904^{\mathrm{I}}$ ) onder leiding van ie luit. A. Franssen Herdersciee, met als deelnemers : luit. t. zee $2 \mathrm{e} \mathrm{kl}$. C. H. de Goeje en arts G. M. Versteec; (voor zoölogie en botanie).

De Toemoek-hoemak-expeditie (Juli-November $1907^{2}$ ) onder leiding van luit. t. zee $2 \mathrm{e} \mathrm{kl}$. C. H. DE GoEJE, met als deelnemer luit. t. zee $2 \mathrm{e} \mathrm{kl}$. H. Bisschop van Tuinen. (Alleen een geologische verzameling werd aangelegd; zoölogisch en botanisch niet).

De expeditie naar de Suriname-rivier (Juni-November I90\$3 ${ }^{3}$, waarvan leider was de luit. ter zee ie kl. J. G. W. J. Eilekts DE HAAN, met als geographisch deelnemer luit. ter zee R. H. Wijmans en als zoöloog-botanicus de officier van gezondheid J. H. A. T. Tresling.

De Corantijn-expeditie (Juli r9ro-April I9II ${ }^{4}$ ) eveneens onder leiding van EILERTS DE HAAN, waaraan deelgenomen werd door luit. ter zee $2 \mathrm{e} \mathrm{kl.} \mathrm{C.} \mathrm{C.} \mathrm{Käyser} \mathrm{en} \mathrm{off.} \mathrm{v.} \mathrm{gez.} \mathrm{der} \mathrm{Kon.}$ Marine J. F. HuLk, aan wien het verzamelen van zoölogisch en botanisch materiaal opgedragen was. Helaas eischte deze

I) A. Franssen Herderschee, ig05. Verslag van de Tapanahoni-expeditie. Met verslag van astronomische plaatsbepalingen door C. H. DE GoEJE, van het voorloopig onderzoek van de gesteente-monsters der Tapanahoni-expeditie door A. Thin en der Gonini-expeditie door H. N. Duyfjes en omtrent de afdrukken van ornamenten door L. C. van Panhuys. (Tijdschr. K. N. A. G. $2^{\text {e }}$ serie XXII, p. $847-1032)$.

2) C. H. DE Gokje, 19oS. Verslag van de Toemoekhoemak-expeditie Met beschrijving der verzamelde gesteenten door J. H. GRUTTERIxk. (Tijdschr. K. N. A. G. $2^{\mathrm{e}}$ serie XXV. p. 945-1169).

3) J. G. W. J. Eilerts ie HaAn, 19ro. Verslag van de expeditie naar de Surinamerivier. Met lijst van planten door A. Puli.e. (Tijdschr. K. N. A. G, $2^{\mathrm{e}}$ serie XXVII. p. 403-468,641-701).

4) C. C. Kayser, 1912. Verslag der Corantijn-expeditie. (Tijdschr. K. N. A. G. $2^{e}$ serie XXIX. p. 442-5I4). 
tocht een slachtoffer: de kranige leider EilerTs dE HAAN over-

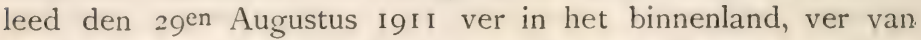
familie en vrienden, zijn leven gevend vo or de zaak.

Van de algemeen-natuurwetenschappelijke expedities en onderzoekingstochten zijn dit de voornaamste: meer speciaalbotanische reizen komen hieronder ter sprake. Aan een door PULLE $^{\mathrm{I}}$ ) gegeven geschiedkundig overzicht van het floristisch onderzoek van Suriname ontleenen we het volgende:

$\mathrm{Na}$ de door een Zweed Dalberg en een Deen Rolander bijeengebrachte verzamelingen, die door een van LinnaEus' leerlingen, JACoBus Alı, in zijn dissertatie en later door Linnaeus fil. in zijn Supplementum plantarum bewerkt werden, kwam in I79 I nog een kleine collectie naar Europa van den Engelschen arts Anderson, in 1823 een van Leschenault en in 1828 een van Weigelt; vooral de laatstgenoemde, die in opdracht van de Saksische regeering reisde, bracht een belangrijk aantal planten bijeen, waarvan een aantal zich thans in 's Rijks Herbarium te Leiden bevinden.

Belangrijk werk verrichtten in den loop der negentiende eeuw allereerst de Duitschers F. W. Hostmann en A. Kappler.

Hostmann vertrok in $18 \mathrm{I} 8$ als arts naar Suriname, waar hij reeds spoedig een aanvang maakte met natuurstudie en met het verzamelen van botanische voorwerpen. Eerst zond hij een verzameling ter bewerking naar zijn leermeester ERNST MEyer te Göttingen (1824), daarna (I840 en I84I) naar Sir Willia.I Hooker te Londen, terwijl hij ze later ( \pm I842) waarschijnlijk wegens geldgebrek, ontstaan doordat zijn liefhebberij en zijn reizen aan zijn artsenreputatie geen goed hadden gedaan, aan Hohenacker verkocht. Omstreeks dien tijd gaf hij zijn practijk

ז) A. A. Pulle, r907. Geschiedkundig overzicht van het onderzoek naar de flora van Suriname. (Bull. Kol. Mus. 38. p. 35-47). 
DE IVEST-INDISCHE BEZITTINGEN.

op, om zich uitsluitend op onderzoek van den plantengroei te gaan toeleggen.

Gelukkiger verzamelaar was A. KaPpler, die zooals we zagen niet alleen verzamelde, maar ook zelf waarnemingen deed en publiceerde over flora en fauna. KAPPLER verzamelde oorspronkelijk dieren, maar na zijn kennismaking met HostuanN ook planten. Vierenveertig jaar lang, onderbroken door zes reizen naar Europa $(1842,1845,1852,1860,1867,1875)$, heeft KAPPLER in Suriname's wildernissen rondgezworven; behalve het genoemde "Surinam” schreef hij reeds vroeger een boekje over zijn eersten tijd in Suriname ${ }^{\mathrm{I}}$ ), en na zijn terugkeer in Europa nog een belangrijk werk ${ }^{2}$ ), vol levensherinneringen en vol goede opmerkingen over de toestanden in Suriname.

$\mathrm{Na}$ Kappler was het de in Suriname geboren H. C. Fockl: ( $1802-1854$ ), jurist van beroep, maar een uitnemend lief hebberbotanicus. Zijn verzamelingen zond hij aan Miฉ̨el te Utrecht gedurende de jaren $I_{35-1} 8_{50}$; na laatstgenoemd jaar verzamelde hij niet meer, maar publiceerde nog wel botanische verhandelingen in het o. a. door hem geredigeerde „Tijdschrift voor West-Indië", bovendien in de "Botanische Zeitung" en in het "Tijdschrift voor Wis- en Natuurkundige Wetenschappen".

Dan moeten nog vermeld worden F. L. Splitgerber ( $\mathrm{I} 8 \mathrm{OI}-\mathrm{I} 842$ ), die in $1 \$_{37}$ een reis naar Suriname maakte, en na terugkomst zelf de bewerking van zijn materiaal ter hand nam, H. Keger, die in de jaren $\mathrm{IS}_{44}-\mathrm{I} \mathrm{S}_{4} 6$ in opdracht van de tuinbouwfirma Van Houtte te Gent een verzamelreis naar Suriname maakte, maar zelf weinig publiceerde, H. R. Wutuscuiäial, een Hernhutter zendeling, die van $184+$ tot 1847 en van

1) A. Kappler, 1854 . Zes jaren in Suriname. Sichetsen en tafereelen wit het maatschappelijke en militaire leven in deze kolonie. (Ltrecht, IS54).

$\Rightarrow$ A. KAprler, rSSr. Holländisch Guyana. Erlebnisse und Erfahrungen während eines 43-jährigen Aufenthalts in der Kolonie Surinam. (Stuttgart, ISSI). 
DE WEST-INDISCHE BEZITTINGEN.

I 848 tot 1855 in Suriname werkzaam was en hier een belangrijke collectie bijeenbracht en enkele verzamelingen van minder beteekenis, zooals van Dr. F. Voltz, lid van de Duitsche commissie van onderzoek, uitgerust met het doel na te gaan, in hoeverre Suriname als kolonisatieland aanbeveling verdiende en van den arts Dr. Demontier te Paramaribo. De hernieuwde belangstelling na 1885 kwam ook de kennis der flora van Suriname zeer ten goede: behalve door de verschillende genoemde Suriname-expedities werd door Prof. F. A. F. C. IVEnt, die in Igor de kolonie bezocht, vooral ter bestudeering der landbouwtoestanden, belangrijk materiaal verzameld.

Naast de standaardwerken ,Flora Brasiliensis”, waarin ook de flora van Suriname werd opgenomen en Miquel's ,Stirpes Surinamenses selectae" ") verschenen als bewerking der verschillende collecties tal van kleinere verhandelingen; het nieuwste materiaal (na I885) werd door Pulle ${ }^{2}$ ) bewerkt, die thans ook voortdurend aanvullingen ${ }^{3}$ ) publiceert uit de bijkomende verzamelingen, waarvan een groot gedeelte aan de werkzaamheid van de ambtenaren van het boschbeheer te danken is. Zelfs is de kennis van Suriname's flora thans zoover gevorderd, dat het mogelijk geweest is, een zakflora voor de families en geslachten der in Suriname voorkomende phanerogamen en vaatkryptogamen samen te stellen ${ }^{4}$ ).

Op de Nederlandsche Antillen was vóór i 885 alleen door buitenlandsche onderzoekers verzameld en wat er aan botanisch

ז) F. A. W. Mrquel, I851. Stirpes Surinamenses selectae. (Verh. Holl. Mij. v. Wet. Haarlem, VII).

${ }^{2}$ ) A. A. Pulle, 1906. An enume ration of the vascular plants known from Surinam, together with their distribution and synonymy. (Leiden, 1906).

3) A. A. Pulle, 1907-I912. Neue Beiträge zur Flora Surinams. I-III. (Rec. Trav. bot. Neerl. IV. p. II9-I4I; VI. p 25I-293; IX. p. 125-169).

4) A. A. Pulle, rgri. Zakflora voor Suriname. Deel I. (Bull. Kol. Mus. 47). 
materiaal bijeengebracht werd, verzonk dan steeds in het niet in de groote standaardwerken over de omliggrende eilanden, waarvan vooral dat van URBAN: Symbolae Antillanae grenoemd moet worden. Na 1885 waren het grootendeels Nederlandsche reizigers, aan wie botanische verzamelingen te danken waren: Prof. IW. F. R. Suringar (i $884-1885$ ), Prof. F. A. F. C. Went (igoi), Dr. J. Boldingh (igog-igio), Prof. N. L. Britton en Dr. J. A. Shafer (I9I3) bezochten Curaçao, Boldingir bovendien Aruba en Bonaire, terwijl de eilanden boven de wind bezocht werden door Suringar (i885), Went (ig02) en Boldingh (igo6). $\mathrm{Na} 190$ I werden voor het natuuronderzoek van West-Indië toelagen beschikbaar gesteld uit het VAN EEDEN-fonds, in beheer bij het Koloniaal Museum te Haarlem. Bovendien werden op Curaçao, St. Eustatius en Saba belangrijke verzamelingen aangelegd door aldaar vertoevende personen. De bewerking van deze moderne collecties is, afgezien van Suring.AR's publicaties, voornamelijk over Cactaceën, geschied door Dr. I. BoldingI, die behalve een uitvoerig werk ${ }^{\mathrm{r}}$ ) met wetenschappelijke strekking, thans ook een meer populaire flora $^{2}$ ) in het licht gegeven heeft.

Wetenschappelijk zoölogisch werk is totnogtoe vrij weinig verricht: behalve Kapplers studies en de verzamelingen der Suriname-expedities in het Leidsche Museum werd in Suriname eigenlijk alleen verzameld en gewerkt door de gebroeders F. P. en A. P. PEnard over de vogelwereld ${ }^{3}$ ).

Ook geologisch onderzoek is in onze West-Indische koloniën

1) I. Boldingh, I909-I9I4. The flora of the Dutch West-Indian Islands. I. St. Eustatius, Saba and St. Martin, II. Curaçao, Aruba and Bonaire. (Leiden, 1909-1914).

2) I. Boldinghi, igi 3 . Flora voor de Nederlandsche West-Indische eilanden. (Amsterdam. Koloniaal Instituut, 1913).

3) F. P. en A. P. Penari), igos-1910. De vogels van Guyana. (Suriname, Cayenne en Demerara). 2 dln. (den Haag, rgoS-igro). 
DE WEST-INDISCHE BEZITTINGEN.

nog te zeldzaam geweest; van het door Dr. F. Voltz in het midden der negentiende eeuw gedane werk is weinig terecht gekomen ${ }^{\mathrm{T}}$ ); Martin en van Cappelle en na hen de Surinameexpedities zijn de eenigen geweest, die over Suriname geologische gegevens hebben bijeengebracht; over de Antillen danken we publicaties aan Martin en Molengraaff.

En ten slotte wordt toegepaste natuurwetenschap beoefend: In het eind van de negentiende eeuw werd een Cultuurtuin gesticht, die als gevolg van Went's studiereis (I9OI) een onderdeel werd van de op te richten Inspectie van den Landbouw ${ }^{2}$ ). Tot Inspecteur van den Landbouw werd in 1903 benoemd Dr. C. J. J. van Hall, die op Curaçao een landbouwkundige onder zich kreeg. Na Van HaLl's vertrek kwam Dr. P. J.S. CRAMER in diens plaats. Thans zijn naast den directeur (J. Huizinga) een plantkundige en een scheikundige werkzaam en worden allerlei landbouwkundige onderzoekingen, ook meteorologische waarnemingen gedaan, terwijl op Curaçao een adviseur voor visscherijzaken gevestigd is.

In enkele opzichten is er den laatsten tijd veel tot stand gekomen in onze West; veel meer echter blijft er nog te verrichten; natuurwetenschappelijk onderzoek kan, mits goed georganiseerd, de basis worden voor een bloeiende welvaart in ons te weinig bekende West-Indisch Nederland.

1) Zie Martin, I888. t. a. p. II. p. I42 en I78.

2) Bulletin van het Departement (Inspectie) van den Landbouw in Suriname. I-... (I904-heden). 


\section{Register van persoonsnamen.}

(De cursief gedrukte getallen verwijsen naar voetnoten; de jaartallen tusschen () en de daaropvolgende getallen hebben betrekking. op. volledige titelopgave der geschriften).

Abendanon. E. C., I8I.

Acquet. Dr. d', 49.

Adams. A., 138 .

Agardh, 137.

Albarda. H., I6S.

Alderwerelt van Rosenburgh. C. W. R. K. van. 212.

Alm. J., 290.

Almeloveen. Th. J. ab, 22

Altheer. J. J., 227.

Alting. IV. A., 79.

Amann. J., zie S. Kurz.

Anderson, 290.

Backer. C. A., 200, 212.

Backer Overbeek, 256.

Bakhuis. L. A., $17 I$, 288; (1902) 288.

Banks. Joseph, 67 .

Baud. J. C, 124.

Bartlo. S., 77,80 .

Beaufort. L. F. de, 176, 181, 182, 225; (I)12) 182, (1913) 181, (1913) 226.

Beccari. O., 166, 194; (1877-1890) 166 , (1885) $194,(1902) 166$.
Bedot. M., 173; (1893) 173 .

Beekman. E. H. M., 287.

Beele. Sloet v. d., I89, 256.

Bélangé, I24.

Belcher. E., I38: (1848) $x_{3} 8$.

Bemmelen. J. F. van, 171, 219; (rS95) $I 7 I$.

Bemmelen. J. M. van, 239.

Bemmelen. IV, van, $I 8 I, 258-260$; (I9I3) 250.

Bennet. J., 82.

Bentham. C., 150 .

Berchthold. F, von, I7 r.

Bergsma, P. A., 255-258.

Bernard. Ch., 279.

Bernstein. H. A. I64, I65; (1564) 165 , (1869) $x 05,(1883) 165$.

Bevere. de, 69.

Beyrich. E., 243; (1864) 243.

Bickmore. A. S., 166; (1868) 166.

Bik. A J., 89, 93, 96.

Bik. J. T., 96, 106.

Binnendijk. S., 92, 133, 134, 1S4, IS6, InI, 194, 202.

Birnie. D., 280 
Bisschop van Tuinen. H., 289 .

Bleeker, P., 156-162, 216-218; (1853) I77, (1857) $162,(1877) 156$.

Blink. H., (1913) 63.

Blomhert. E., 77.

Blume. C. L., 92, 103, 107-II2, I2I, I26, I28-I3I, I33, I4 I, I46, 23I ; (I825-I826) $I 07,(1828) I I 2,(1835-1848) I 07,(1858)$ $I I 2$.

Bock. C, r68.

Boden Kloss. C., I80.

Boehm. G., 56, 180, 241, 246, 247 ; (1900) 56.

Boerlage. J. G., 168, 208, 21 1, 273 ; (1890I900) $2 I T,(\mathrm{I} 894) \mathrm{I} 26$.

Boie. H., 100, 105; 107, II2-116, II8; (1830) 107.

Boisduval, 137 .

Boldingh. I., 293; (1989-I9r4) 293, ('1913) 293.

Bontius. Jac., 5-12, 44; (1642) 7,(1658) IO. Bontius. W., ro.

Boom. H., 22.

Boom. Th., 22.

Boon. M. A., 288.

Boorsma. W. G., 237, 28 r.

Bormans. A. de, I68.

Bosch. W., 157 .

Bosch. J. v. d., 124, I25.

Bosch. R. B. v. d., I5O, 2 IO, $21 I$; (186r) $2 I T$.

Bosz. J. E. Q., (19ro) 234.

Bougainville, 67, 7 r, 72 .

Braak. C, 259260.

Branderhorst. B., 178 .

Brauer, T., 164.

Breda. J. G. S. van, 108; (1827-I829) 108.

Breddin. G., 225; (I901) 225.

Breen. H. van, 289 .

Britton. N. L., 293.

Brogniart. Ad., 137.

Brouwer. H. A., 182 .

Brown. R., 82.

Bruyn. A. J. de, 150.

Bruyn. J. C. de, II 3.

Bullen-Newton, 247 .
Burck. IV., I97, 201, 202, 206, 209, 214 , $272-274$.

Burgersdijk. L. A. J., 150.

Burman. Joh., 4I, 42, 49, 80; (I737) I2.

Burman. N. L., 80, 81 ; (1768) 8r.

Bus de Gisignies. L. P. J. du, IIo, II4I16, 122, 123 .

Buse. L. H., 97, I5O.

Busken Huet. Cd., I8, 20; (1886) 18.

Bussy. L. P. le Cosquino de, 277.

Büttikofer. J., I 7 I.

Buys Ballot, 255, 256.

Buyskes. A. A,, 85 .

Bijlert. A. van, 277 .

Camphuys, $38,39,57,65,80$.

Capellen. G. A. G. P. v. d., $85,93,94$, I03, 105, 106, I10, 114.

Cappelle. H. van, 287, 294; (1907) 287, (I908) 287.

Casearius. J., 19, 22.

Catuffe. J., 42.

Changuion. F., 42 .

Chartrouse. M. L. de, (1838-1839) 107.

Chasteleyn. Cs., 39.

Chun. C., I74; (1902) I74, (1902-19..) 174.

Cleyer. A., 57, 58.

Commelin. J., 22, 23.

Commerson, 67 .

Cook. J., 67, 73 .

Costerus, J. C., 215.

Coupvent-Desbois, 138 .

Coyett. B., 68.

Cramer, P. J. S., 282, 294.

Cretier. H., 228.

Crul. D., 37.

Cuvier. G., I07; (1828-1849) 107.

Dalberg, 290.

Dalhuisen. A. F. H, I79.

Decaisne, 138.

Deninger. K., I80.

Deventer. W. van, 269; (I906) 269.

Diard, I15-II7, I19, 125-130, 196. 
Dole. A، van, 42 .

Donati, 63.

Doria, G., I66.

Douville, 250.

Dozy. F., I50, 210 ; (1844) 210,(1845-1848) $2 I O,(1855-1870) 2 I I$.

Drimmelen. C. van, 287 .

Dubois. E., 24I ; (I894) $24 I$.

Dumas. F. H., 178 .

Dumontier, 292.

Dumoutier, 138 .

Duperrey, II5, I37; (1826-1838) I37.

Duyfjes. H. N., 289.

Dyck. J. van, 22.

Earle. W., 221, 222; (1845) $22 T$.

Easton. N. Wing, 24I, 247.

Edwards. G., (1758) 69.

Eeden. F. W. van, 205, 235, 284, 287; (1896) 284.

Eerens. de, I26.

Eilerts de Haan. J. G. W. J., 289, 290; (I910) 289.

Elbert. J., I8r, 2I2, (I9II-I9I2) I8I.

Elliot, 254.

Elout. C. T., 85, 93.

Elzevier. L. et D., Io.

Ernst. A., 200; (I907) 200.

Esenbeck. Nees von, 150.

Eivijk. van, II5.

Eyck. Ph. van, 38.

Eyken. P. A. A. F., 228.

Eykman. J. F., 205, 233.

Faber. F. C. von, 28r.

Fabre, 124.

Falck. A. R., 85-87.

Fallours. S., 68.

Felder, C., 164 .

Felder. R., 164.

Fennema. R, 24I, 243; (I896) $24 I$.

Fenzl. E., 164 .

Figee. S., 258, 259; (1910) 259.

Fliegel. G., 243; (1898) 244, (1901-1902) 244 .
Flückiger. F. A., (1893) 220.

Focke. H. C., 188, 291.

Forbes. H. O., 168; (1885) 168.

Forsten. E. A., II9.

Frauenfeld. G. von, I64.

Freycinet. L. de, 136; (1824-1844) 136.

Fritze. E. A., I19, 127, 145.

Fromberg. P. F. H.. 134, I40, $227,228$.

Gaertner. J., 8I ; (1788-I 79I) 8I.

Gaffron. H. von, I20.

Gaimard, 136, 137 .

Garnot, 137 .

Gaudichaud. Ch., 136.

Geinitz. H. B., 244, 247.

Gelder. D. H: R. van. II -IIg.

Gelder. J. K. van, 178 .

Gesker. van, 133 .

Gevers. P., 77.

Gjellerup. K., 178, 179.

Goebel. K., 60, 203, 214; (1902) 60.

Goeje. C. H. de, 288, 289; (I 908 ) 289.

Goodfellow. W., 179.

Gooszen. A. J., 178; (1913) 178.

Göppert. H. R., 150; (1854) 150.

Gorkom. K. W. van, 3, 195, 228, 229, $23 \mathrm{I}-233$; (1880) 195, (1880-188r) 232, (1884) 232, (1913) 232.

Gorter. K., 282.

Gosse. P., 42.

Grange. J., 138 .

Greshoff. M., I, 2, 59, 99, 102, 199, 205, $206,215,227,229,233-239$; (1891) 80 , (1903) 99, (1906) 227, (I909) 68.

Grube. E., 164.

Grunow. A., 164 .

Grutterink. J. H., 289.

Guillemard. F. H. H. I68; (I886) I68.

Haan. de, I07.

Haan. J. v. Breda de, 277, 286.

Habbema D., 177

Haberlandt. G., 203, 204; (1893) 204.

Hackius. F., 7, 10 .

Haeckel. E., 204. 
Hagen. B., 218.

Hall. C. J. J. van, 281, 282, 294.

Hallier. H.. I7I, I8I, 212; (1912) 212.

Halma. F., 49.

Hann. J., 258; (1897) 258.

Harting. P., 4I, 156 ; (1885) $4 \mathrm{r}$.

Hasselt. A. L. van, $167, \mathbf{1 6 8}$.

Hasselt. A. W. M. van, I68.

Hasselt. J. C. van, 2, 97, 98, 100-108, II2, II3, II5, I39; (1820) IOI, (I820) IO2. Hasskarl. J. K., 23, 46, 92, I26-132, I40, $147,148,150,184-186,196,229,230$; (I86I) 23, (1862) 23, (1865) 132, (1866) 46, (1867) 23.

Hauer. F, von. I64.

Haug. E., (1900) 252.

Healey. M., 247.

Heeren. A. H. L., 84; (1830) 84.

Heeres. J. E., (1902) 32.

Heldring. O. G., 178 .

Heller. C., I6 4 .

Henschel. A. G. E. Th., 38, 44, 46; (1833) 38 . Herderschee. A. Franssen. 177, 178, 288, 289; (1905) 288, (1905) 289.

Herklots. J A., I5I ; (I854) 151.

Hermann. P., I2, I8, 8I ; (I698) I2, (I7I7) I2.

Heuvel. H. H. v. d., 74 .

Hickson. S., 168.

Hirschi. H., 246.

Hissink. D. J., 277.

Hochstetter, F. von, 164 .

Hoedt. D. S., $164,165$.

Hoernes. M., I64.

Hoëvell. IV. R. van, 14, 66, 83, 157, 159; (I839) I4.

Hogeboom. Jb., 37 .

Hogendorp. W. van, $76,77,79$.

Hombron, 138 .

Hooker. W., 290.

Hooper. J., 90, 93, 109, 124.

Hooyman. J. 76, 77, 79 .

Hooze, J. A., 24I.

Horner, Ir9, I40.

Horsfield. Th, 81, 82, I40; (1824) 82, $(1838-1852) 82$.
Horst. R., 50, 5I, 168; (1902) 50.

Hostmann. F. W., 290, 291.

Houten. P. J. van, (1906) 68.

Houtman, 2, 70.

Hubrecht. A. A. W., 168, 17 I, 174

Hubrecht. P. F., I77-179.

Huizinga. D, (I895) 237.

Huizinga J., 294.

Hulk. J. F., 289.

Humboldt. A. von, 254.

Huysmans. J. W., 175 .

Iperen. $\mathrm{J}$. van, 77,79 .

Iterson. F. K. van, (1910) 234.

Jacobson. E., 218.

Jacquinot, 138 .

Jager. H. de, 57 .

Janse. J. M., 206; (I892) I84.

Janssonius. H. H., 208; (I906-I9..) 208.

Jensen. $\mathrm{Hj}$., 278 .

Jong. A. W. K. de, 238, 282.

Jong. J. de, 53.

Jonkman. H. F., 168.

Junghuhn. F. W., I31, I39-I53, 185, 2 13, 229-231, 242, 254; (1830) $143,(1850-$ 1854) 147.

Kaempfer. E., I3-I5; (I727) I4, (I728) I4, (I729) I4, (1777) I4.

Kampen. N. G. van, 179, 225; (183I1833) 64.

Kampen. P. N. van, 179,225 ; (19091913) 225.

Kan. C. M., $I 70$.

Kappler. A., 285, 290, 29I, 293 ; (1854) $29 I$, (I88I) 29I, (1887) 285.

Karsten. G., 203, 213, 215; (1891) 213.

Kate. H. F. C. ten, 170, 246; (1894) I7O.

Käyser. C. C., 289; (1912) 289.

Kegel. H., 29I.

Kemp. P. H. v. d., $90, I I I$; (I9I4) $\delta o$. Kent. W, 89, 90, ro9.

Keultjes. J., 97, 105, II3. 
Kinderen. H. T. der, (1878) 77.

Kleiweg de Zwaan. J. P., I74, I81 ; (1913I914) 182.

Klerk. R. de, 75-77.

Kner. R., $I 64$.

Kobus. J. D., 270.

Koch. J. W. R., 177.

Koch. K. F., 178 .

Kock, P. J. de, 288.

Kohlbrugge. J. H. F., 218.

Koningsberger. J. C., 28r.

Koorders. S. H., I50, 171, 207, 208, 212 ; (iS94-I9I4) 208, (1908-r9ro) I5O, (r910) 150 .

Kopp, I79.

Korotneff. A. A., I68.

Korthals. P. W., II7-II9, I2I.

Krause, 247.

Krempelhuber. J., I64.

Kroon. J. E., (I9II) 6.

Kruimel. J. H., (19r3) I8I.

Krumbeck. L., 246.

Kruyff. E. de, 240.

Kuhl. H., 2, 97-108, I15, 139; (I820) I01, (I 820 ) 102.

Kükenthal. W., I73; (1896-1903) I73.

Kurz. S., I85, I86; (I864) I86, (I865) 186.

Laclé. H. N., 77

Lacoste. C. M. v. d Sande, 97, 150, 168, 2 II ; (1856) $2 I I$.

Langen. A., 170.

Leersum. P. van, 271 .

Lemoine. P, (I906) 252.

Leschenault de la Tour, 80, I02, 290.

Lesson, II7, 137 .

Leupe. P. A., 27, 32; (1864) $7 I$, (1871) 32 .

Linnaeus. Car., 290; (1747) 12.

Linnaeus fil, 290.

Linschoten. I. Huygen van, 2, 45, 70.

Lister. M., (1685-1693) 52.

Lodewijks. J. A., 278.

Loos. D. de, 168 .

Lorentz. H. A., 176,177 ; (1905) 176 , (I913) 177 .
Loten. J. C., 68, 69.

Loth. W. L., 288.

Lotsy. J. P., 215, 272; (1902) 38.

Lovink. H. J., 280.

Lubach. D., (I867) 68, (I880) 68.

Luymes. J. L. H., 179.

Maass. A., 173; (1902) 174, (1904) 174, (1910-1912) 174.

Macklot H., I12-I18, 242.

Mac Leay. WV. S., 82; (I885) 82 .

Maetsuyker. J., 30-33.

Maier. P. J., 227.

Man. J. G. de, 53, I68; (I902) 53

Marez Oyens, F.A. M. de Weckerlin de, I82.

Marshall. E., I79

Martens. E. von, 53, 165, 224; (1867-1876) 165 , (1889) 224, (I902) 53.

Martin. Is. de St, 39 .

Martin. K., 15I, 170, 172, 18I, 24I, 247, 250, 286, 287, 294; (1879-1880) I5I, (1885) 286, (I886) 286, (I888) 286, (I 890$)$ $I 70,(1894) 172,(1903) 172$, (1910) $I 40$, (I9II) $18 \mathrm{I}$, (I914) 250.

Massart. J., 204; (I895) 204.

Matthaeus van St. Jozef, I8.

Matthes. C. J, (I872) 187.

Mayer. J. R., I35, 136.

Mayr. G L, 164, 168 .

Mentzel, 58 .

Merkus, II5, I30, I45.

Merton. H., I8r ; (1911-1913) I8I.

Mettenius, G., 164 .

Meyer. A. B., 166, 225; (1898) I66.

Meyer E., 290.

Meyer. J. de, 77.

Meyjes. M. Posthumus, 177 .

Meyjes. R. Posthumus, 170.

Miklucho-Maclay, I66.

Milde. J., I64.

Minto. G. E. Lord, 83 .

Miquel. F. A. W., 97, 108, 149, 150, 187I89. $210,291,292$; (1851) 202, (18551869) $108,(1863-1869) \quad r \delta 8$. 
Modigliani. E., 168.

Moens. A., 79.

Moens. J. C. Bernelot, 23I-233, 272; (1882) 233.

Moerman. C., 288.

Moetjens. A., 42.

Mohnike. O., 218.

Mohr. E. C. J., 240, 282.

Mohr. J. M., 70-74, 255.

Molengraaff, G. A. F.. 17 1, 172, 182, 241, 286, 288, 294; (1886) 286, (1900) 172 , (19I I) $I 82$.

Molkenboer. J. H., I47, I50, 2 10; (1844) $2 I O,(1845-1848) 2 I O,(1855-1870) 2 I T$. Moll. J. W., 208.

Montagne. C., $138,150$.

Moseley. H. N., 167.

Mulder. G. J., 134, 183, 228-23r.

Müller. Karl, (I873) I84.

Müller. S, I13-II5, I18-I21, I39, I41, 219-222; (1839) 220, (1846) 139.

Muller. W. C., I47.

Munnikx. J, 22.

Murray. J., 167.

Musschenbroek. S. C. J. W. van, I65; (1883) 165.

Myer. P., 254, 256.

Nagelvoort. J. B., 228.

Nanninga. A. W., 278 .

Nares. G. S., 167 .

Neaulme. J., 42.

Neaulme. S., 42.

Neumayr. M., 250.

Niermeyer. J. F., 225 (1897) 225, (I910) 150.

Nierstrasz. H. F., I75.

Nieuwenhuis. A. W., I 7 1, 172 ; (1900) 172 , (1904-1906) 172.

Norman. H. D. Levyssohn, 192.

Noronha, 79.

Nouhuys. J. W. van, 177 .

Oettingen. A. von, (1909) is6.

Ogilvie-Grant, 179 .
Onnen. P. L, 254

Oort. P. van, II3, II5, II 8 .

Orta. Garcia ab, 9, 44.

Ostwald. W, (1909) 135.

Oudemans. C. A. J. A., I68.

Oudemans. J. A. C. 255; (1882) 255.

Overdijk. B. N., 117-I19.

„Papageno" 29; (1896) 26.

Pahud. C. F., 145, 229, 254.

Panhuys. L. C van, 288, 289.

Pelzeln. A. von, $I 64$.

Penard. A. P., 293; (1908-1910) 293.

Penard. F. P., 293; (1908-1910) 293.

Penzig. O., 200; (1902) 200.

Persoon, I37.

Petit-Thouars. 1. M. A. A. du, 58; (1825) 58.

Phaff. J. M., (1913) 264.

Pictet. C., 173; (I893) 173.

Piepers. M. C, 218.

Pierot. J., I29.

Piso. W., I0, II; (1658) 10.

Planten. H. O. W., 170; (1892-1893) I7O.

Plugge. P. C., 237.

Poivre, 67.

Poll. v. d., II 5

Poll. J. R. H. Neervoort v. d., 286.

Poot. A. van, 22, 23.

Pop. G. F., (1868) 7, (1870) 8 .

Popta. C:, 181 .

Prinsen Geerligs. H. C., 232, 270.

Provost, 67.

Pulle. A. A., I77, 288, 289; (1906) 292, (I907) 290, (I907-I9I2) 292, (I0II) 292.

Pijnappel. J., $90,9 I, 96$.

Quoy, 136, 137.

Raalten. G. van, 97, 105, 106, 115-I17. Radermacher. J. C. M., 75-80.

Raffles. S., 82, 83, 84; (1822) 84.

Rawling. C. G., I79; (I913) 179.

Redtenbacher. L., $I 64$. 
Reede tot Drakestein. H. A. van, $13-24$, $42,44,60,62,185 ;(1678-1703) 2 I$.

Reichardt. H. W., 164.

Reinwardt. C G. C, 85-97, 102, I21, 126, 129, 196; (1823) 95, (1856) 96, ( 1858 ) 90

Renard. L., 68; (1754) 68.

Rhyne. W. ten, 22, 57 .

Richard, 137.

Richthofen. F. von, 148, 242; (1862) 243.

Riemsdijk. van, 75 .

Ritsema Czn. C., 168.

Rochemont. E J. de, I77.

Rochussen. J. J., 145, I58.

Roemer. F. 243, 246; (1880) 243.

Rogenhofer A., 164.

Rolander, 290.

Romburgh. P. van, 206, 238.

Römer. L S. A. M. von, 177 .

Rosenberg. C. B. H. von, 164, 165.

Rosny. L. de, I3; (I865) 13.

Ross. J. T., 8I.

Rost van Tonningen. D. W., (1859) 134. Rothpletz. A., 243. 252; (I89I) 244, (I892) 243.

Rouffaer. G. P. en W. C. Muller, 48 ; (1902) 26.

Roux. J., I8r.

Rumphius. G. E., $13,15,24-62,64-66$, IO2, I52, I53, I85; (I74I-I755) 4I, (1705) 48.

Rumphius. P. A., 37, 38, 40, 58.

Ruyter. P. de, 39.

Ryckevorssel. E. van, 257, 260.

Sabine, 254, 256.

Sachse. F. J. P., 178, 179.

Sande. G. A. J. v. d., I76.

Sarasin, F., 173, 223, 225; (1898-1905) 173 , (I90I) 223 , (I905) 173.

Sarasin. P., 173, 223, 225; (1898-1905) 173 , (I901) 223, (1905) 173 .

Saussure. H. de, $I 64$.

Schaeffer. A. B. W., 178 .
Scheffer. R. H. C. C., 92, 189-I98; (1870) I94, (1873) I94.

Schelle. C. J. van, 24I, 243, 244.

Schepman. M., I68.

Scherzer. K von, I64.

Schimpes. A. F. W., 203, 213, 214; (1891) 213.

Schiner. J. R., 164.

Schlegel, I21, 165.

Schmidt. A. H., 175 .

Schmidt. M. C. P., I47; (1909) 143.

Schneider. C. F. A., 242, 243.

Schott, G. 263; (1902) 263.

Schouten. S., 42.

Schouw Santvoort, I67.

Schouwman, 80.

Schultze. L., I 79.

Schwaegrichen, 137.

Schwaner. C. A. L. M., 120, I22, 129 , 13I, I32, I4I, I48; (I853) I2O.

Schijnvcet. S., 49, 53.

Sclater. P. L., 221 ; (I858) 221.

Selenka. E, 172, 203, 204.

Semon. R.. 172, 204; (1894-1903) 173, (1896) 173.

Serrurier. L., 16I.

Seyff. R. F. de, 242, 243.

Shafer. J. A., 293.

Sherard. W., 12.

Sichel. J., I64.

Siebold. von, 129, r30.

Siegenbeek. M., 95.

Sipman. J. P., 39, 53.

Sloane. H., I4.

Sluiter. C. P., 170, 219.

Smitt. J. J, 208, 212, 28I.

Snell. L. A., I77.

Snelleman. J. F., 167.

Snellen. P. C. T., 168.

Solms-Laubach. H. von, 202, 203, 214.

Soltwedel. F., 270.

Someren. J. van, 22.

Sonnerat. P., 67, 117; (1776) 67.

Splitgerber. F. L., 29 r.

Spring. A., 150. 
REGISTER VAN PERSOONSNAMEN.

Stahl. E., 203, 215.

Steege. J. v. d., 77, 79.

Steindachner. F., $I 64$.

Stockum. A. J. van, 288; (I904) 288.

Stok. J. E. v. d., 282

Stok. J. P. v. d., 256-26r ; (I897) $26 r$, (I9I0) $26 I$, (I9I3) 255.

Stollé, 179.

Stresemann. E. I80.

Strubell. A., 172, 203.

Suess. E, 250; (1883-1909) 252.

Suringar. W. F. R., I68, 286, 293 ; (1886) 286.

Suringar. J. Valckenier, 286.

Susanna. J A., (1830) II4.

Swaving, C., 6, 8, 9, II ; (1868) 6, (1868) 9 .

Swinderen. van, 97-105.

Syen. A. van, 22.

Tauern. O. D., I80.

Temminck. C. J., 97, 102, 103, 105-ro7, II3-II6, II 8 , I2I, I22, I4I, I46; (I8271841) IO7, (1838-1839) IO7.

Teysmann. J. E., 46, I24-I33, I40, I83191, 194-196.

Thomson. C. Wyville, I67, 262.

Thomson. F. T., 167.

Titsingh 79 .

Tobler. A, I8I, 24I, 246, 247.

Tresling. J. H. A. T., 289.

Treub. M., I, 9I, 92, I10, 124, I28, I30, 132, 160, 16r, 170, 17 1, 195-215, 219, $234,235,266,270-273,276,280-282$; (1888) I99, (1889) 92, (1890) I25, (1892) 9I, (I892) 210. (1898) 201, (I910) 266. Tromp de Haas. W. R., 238.

Tschirch A., 203, 215.

Tulleken. J. E., 287.

Twist. A. J. Duymaer van, 162, 218.

Tydeman. G. F., 175, 262, 264; (1903) 262, (I913) $26 r$.

Urban. I., 293.

Urville. Dumont d', II 7, I37 ; (1830-1834) 137, (1841-1854) 138 .
Uytwerf. H., 42.

Uytwerf. M., 42.

Valenciennes. M., 107; (1828-1849) 107.

Valentijn. F., 9, 47, 48, 57, 64-66; (1724I726) 64.

Valeton Sr. Th.. 208, 212; (1894-1914) 208.

Veltman. A. G., 228.

Verbeek. R. D. M., 56, I5 I, $180, I 81$, $24 \mathrm{I}, 243,245,246-249.252,253$; (1875) 243, (1883) 244, (I896) 24I, (I900) 56 , ( 1903) 241 , (í1908) 245, (1910) 151 , (1910) 245, (1912-1914) 24I, (1913) 245.

Verhuel. Q. M. J. 96.

Versluys. J., 175.

Versteeg. G. M., I77, 288, 289.

Versteeg. IV. F., I67.

Veth. D. D., I67.

Veth. H. J., I, I22, I23, I6I; (I879) I22.

Veth. P. J., I8, 20, 23, 71, 9r, 93-95, 167: (1857) $77,(\mathrm{r} 884) 87,(\mathrm{I} 885) 71,(\mathrm{I} 887)$ 15.

Vincendon-Dumoulin. C. A., 138 .

Vincent. Bory de St. I37.

Vlaming. C. de, 68.

Vogel, 257.

Voltz. F., 292, 294.

Volz. W., 174, 24I, 246.

Vorderman. A. G., 218.

Vriese. W. H. de, 9I, 96, 97, I33, 134, I47, I50, 186, 231 ; (1855) I84, (1858) go.

Vrij. J E. de, 229-233.

Wakker. J. H., 269, 270; (1898) 269.

Wallace. A. R., $162-164,222,223,264$; (I855) I $163,($ I 858$) 163$, (I859) 222, (I 864 ) 164, (1876) 223.

Wanner. J., 180, 24I, 246.

Warburg. D., 47, I62, 203, 212 ; (1891) 212, (I897) 47, (1902) I62.

Wassink, 257 .

Water. A. v. d.. 180.

Weber, 178 . 
Weber. Max, 169, 170, 174, 175, 182, 204, 224-226, 262; (1890-1907) I69, (1894) 224, (1899) 51, (I902) 225, (1902-1914) I75, (I908) 225, (I9II) 225, (I9I2) I82, (I9I3) $I 8 I$.

Weber-Van Bosse. A., I69, I75, 212 ; (1904) 176 .

Weddell, 97, 230 .

Wefers Bettink, 205, 234.

Weigelt, 290.

Went. F. A. F. C., 215, 269, 270, 292-294; (I898) 269, (I9II) 198, (I9II) 205.

Wertheim. C. J. M., I70; (1892-1893) 170.

Whitehead. J., I73; (1893) I73,

Wichmann. A., 54, 59, 169, 170, 176, 241, $244,246,247$; (I890-I892) I69, (I902) 54, (1905) $176,(1909-1912) 176$.

Wielen. P. v. d., (r910) 231.
Wigglesworth. L. W., I66, 225; (1898) I66. Wigman. H. J., 191, 194, 202, 206.

IVillemoes - Suhm. R. von, 167.

Witsen. N., 2, 68.

Wollaston. A. F. R., I79, I80; (I912) 179 .

IVüllerstorf-Urbair. B. von, 164 .

Wullschlägel. H. R., 29I.

Wulp. F. M. v. d., I68.

IVurmb. F. von, 77-80.

Wymans. R. H, 289.

Yzerman. J. W., I7 I.

Zehntner. L., 270, 279.

Zelebor. J., 164.

Zippelius. A, I09, I10, I16, I17, I22.

Zollinger, 132, 133, 139, 186; (1857) 187, (1859) 187. 



\section{S T E L L IN GEN.}

I.

De Systematiek is de wetenschap der specificiteit en kan dus nict langer volstaan met morphologische vergelijking, doch moet het experiment te hulp nemen.

\section{II.}

Zoolang men de meening huldigen mocht, dat geringe morphologische verschillen nauwe, groote verwijdercle verwantschap aantoonden, was op die basis het opstellen van een phylogrenetisch systeem een te benaderen moyelijkheid. Sinds evenwel de bastaardeering geleerd heeft, dat - men beschouwe

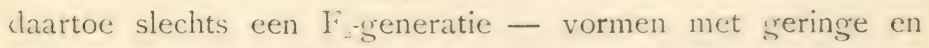
met groote verschillen in denzelfden graad van verwantschap tot elkaar kunnen staan, ontralt de gebruikelijke basis aan de phylogenie.

\section{III.}

Het gebruik van de term , latent" in de genetica, zonder zéér nauwkcurige omschrijving van dezen term, is onvoorwaardelijk af te keuren. 


\section{IV.}

Tot statistische behandeling van biologisch materiaal mag men slechts overgaan, wanneer iedere mogelijkheid van exact experimenteel werk uitgesloten is.

\section{V.}

CAsteE's uitspraak: „The biologists pure line is an imaginary thing" (Journ. of Heredity. V. I9I4, p. 93) is onjuist. Beter ware het hier te lezen: „De ,zuivere lijn” der biologie is wel gemakkelijk te definieeren, maar moeilijk te verwezenlijken: de grootste moeilijkheid schuilt in het feit, dat de middelen, waarover wij op het oogenblik beschikken, onvoldoende zijn om de zuiverheid der ,zuivere lijn" te bewijzen."

\section{VI.}

Experimenteel is de erfelijkheid van verworven eigenschappen onbewezen.

\section{VII.}

Haxs Winklek's definitie: „Bastarde sind Organismen, deren Eltern verschiedenen systematischen Einheiten angehören " (Unters, uiber Pfropf bastarde I. p. 6), is onhoudbaar.

\section{VIII.}

Indien de opvatting van DE Vries juist is, dat Oenothera biennis ,heterogaam" (sensu IIE VRIEs) is, dus ,im Pollen und 
in den Eizellen verschiedene erbliche Eigenschaften auf die Nachkommen ibermittelt" (Gruppenweise Artbildung, 1. 31), dan is deze soort bijzonder ongeschikt om als objekt voor mutatieproeven te dienen.

\section{IX.}

Terecht schrijft Corksis (Biol. Centralbl. XXVIII, I9I3, p. 359-423) de zelfsteriliteit bij planten toe aan "Liniënstoffe”.

\section{$\mathrm{X}$.}

Gamogemmie mag niet als oorzaak van pelorie worden beschouwd (P. Vuthenis, Ann. d. Sc. nat. Botanique, gieme Série, XVI, 1912, 1. IS.7-275), al kan zij misschien in enkele gevallen de oorzaak zijn van het ontstaan van bloemvormen, die men nog onder het begrip ,pelorie" zou kunnen brengen.

\section{$\mathrm{XI}$.}

Noxcks bezwaren tegren de beschouwing cler phototropie als photochemisch proces (Ztschr. f. Botanik, VI, ig If. p. I-79), zijn ongegrond.

\section{XII.}

Het geheele manteloppervlak van Unio en Anoclonta is in staat, zoowel periostracum en prismalaag als parelnoer te vormen.

\section{XIII.}

Aan de opvatting, dat heterochromosomen weslachtsbepalers zouden zijn, ontbreekt het bewijs, clat ze geen vroes optredende geslachtskenmerken zijn. 


\section{XIV.}

De conclusie van Gerschilek (Ztsch. f. ind. Abst. u. Vererb. Lehre, XIII, 19I4, p. 74), dat uit zijn kruisingsproeven zou volgen, dat Amphidasys betularius doubledayaria een mutant van Amphidasys betularius L. zou zijn, is onjuist.

\section{XV.}

De gonophoren van Hydractinia echinata zijn, in tegenstelling met GOETTE's opvatting (Ztschr. f. wiss. Zool. Bd. S7, 1907) homoloog met de Hydromedusen.

\section{XVI.}

Ten onrechte meent Martin (Samml. Leiden, I9I4, p. 337-355), dat in het eoceen reeds een barrière zou ontstaan zijn, waardoor het Indische gedeelte van het Mediterrane deel der Thety's gescheiden werd.

\section{XVII.}

Popularisatie van natuurwetenschappen mag nooit een wetenschappelijk onzekere meening als feit voorstellen. 



